
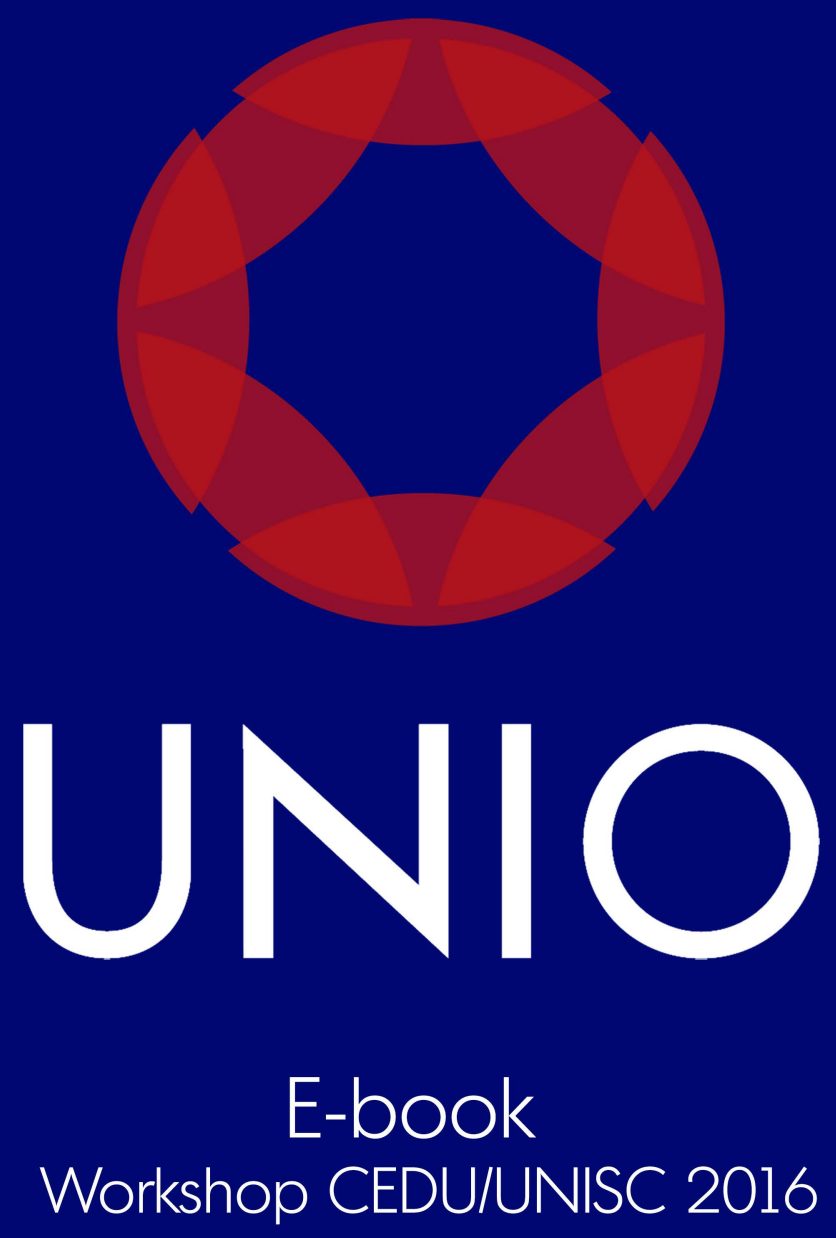

Interjusfundamentalidade, Internormatividade e Interjurisdicionalidade

\author{
Coordenação científica \\ Alessandra Silveira
}





\section{UNIO E-book Workshop \\ CEDU/UNISC 2016: \\ Interjusfundamentalidade,}

Internormatividade e

\section{Interjurisdicionalidade}

Coordenação científica de Alessandra Silveira
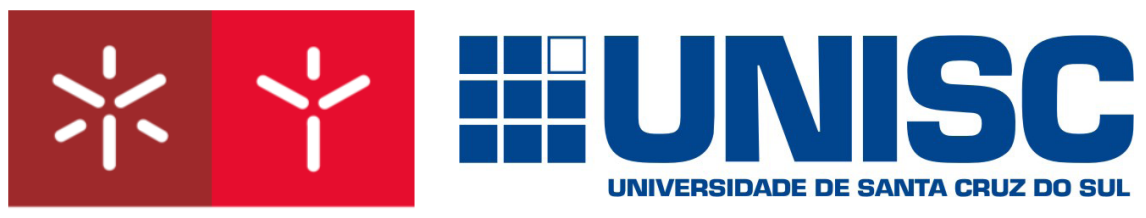

Universidade do Minho

Escola de Direito

Centro de Estudos em Direito da União Europeia 


\title{
UNIO E-book - Workshop CEDU/UNISC 2016: Interjusfundamentalidade, Internormatividade e Interjurisdicionalidade
}

\section{Coordenação científica:}

Alessandra Silveira

\begin{abstract}
Autores:
Alessandra Silveira|Amélie Fernandes |Ana Helena Scalco Corazza|Ana Maria Rodrigues|Andreia Barbosa |Andreia Oliveira|Aneline dos Santos Ziemann|Caroline Fockink Ritt|Cláudia Viana|Cynthia

Gruendling Juruena|Elaine Gonçalves Weiss de Souza|Fábio Roque Sbardellotto|Fernanda de Andrade Freire Lima|Hugo Flores da Silva|Janriê Rodrigues Reck|Joana Covelo de Abreu|João Sérgio Ribeiro|Joaquim Freitas da Rocha| Jorge Renato dos Reis | Juliana Machado Fraga | Larissa A. Coelho | Luís Couto Gonçalves|Luiz Felipe Nunes|Luiz Gonzaga Silva Adolfo|Mara Ahlert|Marco Carvalho Gonçalves |Maria Teresa Alves |Mônia Clarissa Hennig Leal|Ricardo Hermany |Rogério Gesta Leal | Sergio Maia Tavares Marques|Sophie Perez Fernandes
\end{abstract}

\section{Edição:}

Centro de Estudos em Direito da União Europeia

Escola de Direito da Universidade do Minho

http://www.cedu.direito.uminho.pt | cedu@direito.uminho.pt

\section{Coordenação técnica:}

Rita de Sousa Costa|Tiago Sérgio Cabral

Este trabalho é financiado por Fundos Nacionais através da FCT - Fundação para a Ciência e

Tecnologia no âmbito do projeto UID/DIR/4199/2016.

ISSN: $2184-1403$

Braga, dezembro de 2017
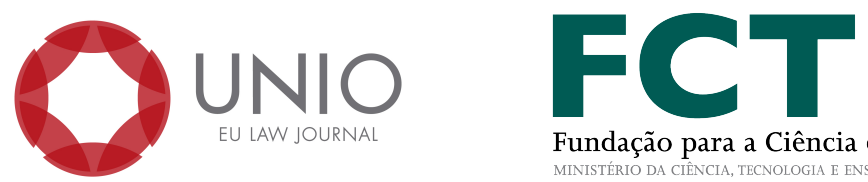

Fundação para a Ciência e a Tecnologi: MINISTÉRIO DA CIÊNCIA, TECNOLOGIA E ENSINO SUPERIOR 


\section{Índice}

Apresentação

Que futuro desejamos para nós próprios, para os nossos filhos e para a nossa União? (a propósito do Livro Branco sobre o futuro da Europa: abram, por favor, o frigorífico!) Alessandra Silveira.

O afastamento de um cidadão da União Europeia por razões de ordem pública e segurança pública: implicações no desenvolvimento da cidadania europeia

Amélie Fernandes

A conjuntura pós-2015 e o espaço de liberdade, segurança e justiça - nótula sobre os impactos ao nível da proteção internacional na União Europeia

Ana Maria Rodrigues.....

O Eurogrupo e o manto de secretismo

Andreia Barbosa......

Da consagração do direito ao esquecimento: (sobre a responsabilidade dos motores de busca no tratamento de dados pessoais)

Andreia Oliveira.

A previsão na Lei Anticorrupção Brasileira de mecanismos e procedimentos internos de integridade: Compliance Corporativo

Caroline Fockink Ritt.

Os contratos públicos como instrumento de concretização de políticas sociais num novo contexto europeu

Cláudia Viana......

A imprescindibilidade da democracia deliberativa na esfera local para uma ampliação na interlocução entre Estado e sociedade

Cynthia Gruendling Juruena......

A ineficiência da execução fiscal em números no Brasil

Elaine Gonçalves Weiss de Soura 
A Lei Anticorrupção Brasileira a partir de sua perspetiva histórica

Fábio Roque Sbardellotto

Ações afirmativas de gênero e a sua eficácia na garantia dos direitos das mulheres no cenário político brasileiro

Fernanda de Andrade Freire Lima.

Breves considerações sobre os critérios jurídicos de realização da despesa pública

Hugo Flores da Silva.

Organizações Sociais e Organizações da Sociedade Civil de Interesse Público como prestadoras de serviços públicos não exclusivos: reflexões em termos de controle e de abertura às práticas corruptivas a partir da interpretação constitucional dada à Lei 9.637/1998

Janriê Rodrigues Reck/Ana Helena Scalco Corazza

O acórdão do Tribunal Constitucional português n. ${ }^{o}$ 591/2016 em matéria de concessão de apoio judiciário a pessoas coletivas com fins lucrativos e a jurisprudência do Tribunal de Justiça - reflexões prospetivas à luz da interjurisdicionalidade

Joana Covelo de Abreu

Implicações fiscais das disposições do TFUE relativas aos auxílios de Estado

João Sérgio Ribeiro

Ponderações sucintas sobre despesa pública e sustentabilidade financeira nos ordenamentos brasileiro e português

Joaquim Freitas da Rocha.

O solidarismo jurídico no constitucionalismo contemporâneo brasileiro: breves notas introdutórias

Jorge Renato dos Reis/Aneline dos Santos Ziemann....

A transparência dos atos da administração pública como mecanismo de combate à corrupção através do controle social: uma análise do caso brasileiro e português

Juliana Machado Fraga/Luiz. Felipe Nunes.

Prolegômenos interconstitucionais: para uma teoria da constitucionalidade europeia

Larissa A. Coelho 
Um paradoxo e um embuste no mercado cultural

Luis Couto Gonçalves.

A crise dos direitos autorais em 20 minutos, ou 10 páginas A4

Luiz, Gonzaga Silva Adolfo.....

A transparência nos interesses que envolvem as relações de mercado e a administração pública

Mara Ablert.

Integração judiciária e tutela jurisdicional dos interesses económicos e sociais

Marco Carvalho Gonçalves.

Crise migratória na União Europeia: as principais medidas adotadas e a defesa dos direitos humanos

Maria Teresa Alves.

Corte Interamericana de Direitos Humanos e Jurisdição Constitucional:

Interconstitucionalidade e diálogo entre Cortes na perspetiva do Supremo Tribunal Federal

Mônia Clarissa Hennig Leal.

Emendas parlamentares e federalismo brasileiro: a governança e governabilidade e sua interconexão com a viabilidade orçamentária a partir da subsidiariedade

Ricardo Hermany.

Fundamentos epistêmicos sobre a importância da participação social no enfrentamento da corrupção

Rogério Gesta Leal......

A Razão Pública por trás do constitucionalismo internormativo da União de Direito Sergio Maia Tavares Marques

Em busca de um sentido de pertença à comunidade nascida da integração por via do estatuto de cidadão da União - de Rottmann a Petrubhin

Sophie Perez Fernandes

Os programas de transferência de renda e a erradicação do trabalho infantil no Brasil Suzéte da Silva Reis 



\section{Apresentação}

Ao abrigo da Cátedra Jean Monnet em Direito da União Europeia, o Centro de Estudos em Direito da União Europeia (CEDU) da Universidade do Minho promoveu, nos dias 14 e 15 de novembro de 2016, o colóquio "Interjusfundamentalidade, Internormatividade, Interjurisdicionalidade". O encontro (formato workshop) resulta da parceria com os investigadores da Universidade de Santa Cruz do Sul - UNISC (Rio Grande do Sul, Brasil) que se associaram aos investigadores do CEDU para um diálogo transatlântico sobre as virtuosidades da teoria da interconstitucionalidade quer na definição da identidade do constitucionalismo europeu, quer na atualização da teoria do constitucionalismo em geral. Esteve em debate o desenvolvimento de uma nova metódica capaz de captar os esquemas cruzados de cooperação, sobreposição e tensão proporcionados pela interjusfundamentalidade, internormatividade e interjurisdicionalidade no âmbito de um constitucionalismo plural e multinível.

Os temas a debate propostos por investigadores do CEDU seguiram os seguintes motes:

*Interjusfundamentalidade: normas de direitos fundamentais em rede e implicações na integração jurídico-constitucional;

*Internormatividade: interação entre normas infraconstitucionais e implicações nas dinâmicas jurídicas de mercado;

*Interjurisdicionalidade: interação entre ordens jurisdicionais e implicações na tutela jurisdicional efetiva.

No dia 14 de novembro, as intervenções foram integradas em quatro painéis temáticos, designadamente: Comunidade política e integração jurídico-constitucional; Democracia económica e transparência nas relações de mercado; Proteção social e não discriminação nas relações económicas; Mercado cultural e proteção da criação intelectual e artística. 
No dia 15 de novembro seguiram-se os seguintes painéis temáticos: Cidadania de direitos, gestão e contratação pública; Integração judiciária e tutela jurisdicional dos interesses económicos e sociais; Despesa pública, tributação, democracia e boa governação. As atividades encerraram-se com a apresentação de trabalhos de pósgraduação previamente selecionados para o efeito, cujos resumos expandidos podem ser conferidos a seguir.

Os contributos agora publicados (ordenados alfabeticamente por autor, sejam painelistas, mestrandos ou doutorandos) resultam do debate de ideias então entabulado no âmbito daquele evento. Os temas desenvolvidos pelos investigadores neste exercício interativo foram amplamente influenciados pelos inputs que receberam através de UNIO - EU Law Journal e do blog que lhe é associado UNIO The official blog - thinking \& debating Europe. Por esta razão, a direção do CEDU decidiu publicar os textos em formato e-book com a chancela da referida revista, disponibilizando-o nas diversas plataformas digitais disponíveis na Escola de Direito da Universidade do Minho. 




\title{
Que futuro desejamos para nós próprios, para os nossos filhos e para a nossa União? (a propósito do Livro Branco sobre o futuro da Europa: abram, por favor, o frigorífico!)
}

\begin{abstract}
Alessandra Silveira*
RESUMO: No mesmo mês em que foram comemorados os sessenta anos do Tratado de Roma - e em que o Reino Unido acionou o artigo 50 ${ }^{\circ}$ do Tratado da União Europeia -, a Comissão Europeia lançou o Livro Branco sobre o Futuro da Europa na tentativa de definir rapidamente um novo caminho para a integração. De entre os vários cenários aventados, a Autora defende aquele que se tradur. (no seu entendimento) no aprofundamento das componentes federativas do sistema europen - e procura explicar o que isto significa nos dias que correm. Assim, a propósito do Livro Branco lançado a 1. ${ }^{\circ}$ de março de 2017, a Autora recupera e atualiza a comunicação apresentada no âmbito do workshop que dá mote ao presente e-book, tentando identificar os principais desafios com que a comunidade política europeia se defronta - em termos de causas e soluções -, na interface das relações entre o económico, o político e o jurídico-constitucional.
\end{abstract}

PALAVRAS-CHAVE: Livro Branco sobre o Futuro da Europa - comunidade politica europeia - aprofundamento das componentes federativas.

ABSTRACT: In the month that marked the celebration of the sixty years of the Treaty of Rome - also the United Kingdom's triggering of Article 50 of the TEU -, the European Commission attempted to define a new path for integration by presenting the White Paper on the future of Europe. Between the possible scenarios enshrined in the White Paper, the Author argues for the one that extends the federative components in the European system - clarifying its current meaning. Furthermore, The Author identifies the main economic, political and constitutional challenges faced by the European political community, their causes and solutions. With this goal in mind, regarding the White Paper presented on 1 March 2017, the Author retrieves and updates the communication delivered within the workshop that served as the basis and inspiration for this e-book.

KEYWORDS: White Paper on the future of Europe - European political community - extension of the federative components.

\footnotetext{
* Titular da Cátedra Jean Monnet em Direito da União Europeia e Diretora do Centro de Estudos em Direito da União Europeia - CEDU.
} 
Em 28 de janeiro de 2017, sete Estados-Membros do sul da Europa (Chipre, Espanha, França, Grécia, Itália, Malta e Portugal) reuniram-se em Lisboa para transmitir a mensagem das suas opiniões públicas nacionais às opiniões públicas dos restantes Estados-Membros da União. E a mensagem era esta: certamente que a União Europeia tem de lutar contra o terrorismo e tem de adotar uma política migratória coesa, mas tais questões não podem desviar as atenções do problema económico. Trata-se de um clamor do sul da Europa no sentido de que a convergência económica passe a ser prioritária na estratégia da União Europeia, através de políticas que criem capacidade financeira na zona euro e o desenvolvimento de programas europeus de apoio ao investimento. Estariam no horizonte soluções que envolvem uma maior partilha dos riscos na zona euro - como sejam a adoção de impostos comuns, de um sistema europeu de garantia de depósitos bancários, a emissão de dívida conjunta (eurobonds), bem como políticas de discriminação positiva para os Estados-Membros endividados que cumprem as regras de ajustamento.

A mensagem dos cidadãos do sul da Europa vai no sentido de que avançaram nas reformas estruturais e de consolidação orçamental tanto quanto lhes foi possível (e os resultados em Espanha e Portugal, sobretudo, são evidentes). Mas nas atuais circunstâncias de forte endividamento e desemprego elevado é impossível continuar nessa senda sem algum alívio dos constrangimentos financeiros, sob pena de conduzir as sociedades mediterrânicas a uma situação de rutura social com consequências imprevisíveis, tendo em conta os populismos à espreita. Tudo isto se insere num debate mais alargado que as instituições europeias estão a travar sobre como produzir mais emprego e melhor desempenho económico, a fim de que os cidadãos europeus voltem a encarar a integração europeia como uma mais-valia para as suas vidas.

Não foi por outra razão que na sua primeira sessão de janeiro de 2017 o Parlamento Europeu aprovou um relatório sobre o Pilar Social ${ }^{1}$. No mesmo sentido, a Comissão Europeia está a avançar com uma série de propostas sobre a gestão

\footnotetext{
1 "Relatório sobre um Pilar Europeu dos Direitos Sociais (2016/2095(INI))", Parlamento Europeu, acesso em julho 30, 2017,_http://www.europarl.europa.eu/sides/getDoc.do?pubRef=-//EP// TEXT+REPORT+A8-2016-0391+0+DOC+XML+V0//PT.
} 
da globalização, sobre o futuro das finanças europeias, sobre o desenvolvimento da dimensão social europeia. E, sobretudo, propostas tendentes a completar a União económica e monetária - que retira soberania monetária e cambial aos EstadosMembros enquanto mantém a sua soberania financeira e fiscal, o que provoca desequilíbrios evidentes entre as economias mais e menos robustas da zona euro. Ademais, a Comissão Europeia apresentou em 1. ${ }^{\circ}$ de março de 2017 um Livro Branco sobre o Futuro da Europa ${ }^{2}$ - que perspetiva as alterações a que estaremos sujeitos nos próximos dez anos e apresenta cinco cenários para enfrentar os desafios atuais e vindouros.

O Livro Branco explica que tais cinco cenários são meramente ilustrativos, destinando-se a suscitar uma reflexão. Não constituem planos pormenorizados nem decisões políticas. Também não fazem, deliberadamente, qualquer menção a processos legais ou institucionais - "a forma seguirá a função". Com os cinco cenários apresentados a Comissão Europeia procura evitar que o debate sobre o futuro da Europa seja reduzido a uma opção binária, entre “mais" ou "menos" Europa - uma abordagem que reputa enganosa e simplista. Por isso as possíveis vias descritas vão desde a manutenção do statu quo a uma alteração do âmbito de atuação e prioridades - ou porventura um salto em qualidade, seja parcial ou coletivo. Existem muitas sobreposições entre cada cenário, pelo que não são mutuamente exclusivos nem exaustivos. Em largos traços, a Comissão sugere que se pode optar entre: 1) assegurar a continuidade do que tem sido feito; 2) restringir a integração ao mercado único; 3) fazer mais com quem quiser mais, numa Europa a várias velocidades; 4) fazer menos com mais eficiência; ou 5) fazer muito mais todos juntos.

Este último cenário estaria em sintonia com os apelos que temos feito no sentido de uma fusão mais complexa entre as competências e os instrumentos nacionais e europeus, pois a vida na União tem de ser diferente dos anos pré-crise e pré-Brexit, tornando-se insustentável a crescente assimetria entre as áreas políticas integradas

\footnotetext{
2 "Livro Branco sobre o Futuro da Europa", Comissão Europeia, acesso em julho 30, 2017, http:// www.europarl.europa.eu/sides/getDoc.do?pubRef=-//EP//TEXT+REPORT+A8-20160391+0+DOC+XML+V0//PT.
} 
e as não integradas. Assim, as crises que a União está a enfrentar (crise económica, crise migratória, crise de identidade, etc.) acarretariam o aprofundamento das componentes federativas do sistema, mas sem passar necessariamente por um "bigbang federal". Isto é, sem a adoção de uma Constituição federal concebida enquanto tal e a renúncia expressa da soberania dos Estados-Membros - porque isto não iria, realisticamente, acontecer.

De resto, nem sequer seria desejável. A União Europeia não é nem deve converter-se num Estado federal, pois está em condições de oferecer ao mundo um modelo bastante mais sofisticado de organização poder político do que aquele do Estado, próprio da modernidade constitucional. Não obstante, a União Europeia funciona como um sistema federativo - e a sua ordem jurídica assenta, desde sempre, na principiologia federativa - lealdade, primado, efetividade, efeito direto, interpretação conforme, etc. A identificação da União Europeia como um sistema federativo ou federação "reporta-se a um modo, mais do que a uma especificação morfologicamente pura"3. De resto, como explicava Carl Friedrich e a sua teoria do federalising process, o federalismo não deve ser considerado como um modelo estático ou um termo fixo e preciso de divisão de poderes entre as autoridades central e periféricas. Há de ser entendido como um processo de federalização de uma comunidade política ${ }^{4}$. É este processo que estamos a vivenciar há quase setenta anos - quer nos tenhamos dado conta, quer não - e que está a demandar aprofundamentos.

Que impacto o quinto cenário proposto pelo Livro Branco (e que defendemos) teria nas políticas europeias? A União Económica e Monetária (também nas dimensões financeira e fiscal) seria concluída. O orçamento da União seria

\footnotetext{
${ }^{3}$ A "federalização" do sistema europeu vem sendo feita há quase 70 anos, desde que a declaração Schuman de 9 de maio de 1950 iniciou a construção de uma União de base federativa com específica referência à "federação europeia". O termo foi amplamente empregue na obra de Francisco Lucas Pires. Cfr. $A$ revolução europeia por Francisco Lucas Pires - antologia de textos (Lisboa: Gabinete em Portugal do Parlamento Europeu, maio/2008), 57, onde se lê: "É nesta lógica que falo de federalização, sem Estado federal".

${ }^{4}$ Sobre a teoria do federalising process cfr. Carl Friedrich, Constitutional government and democracy: theory and practice in Europe and America (Ginn: Boston, 1950), sobretudo capítulos 7 e ss, onde o Autor desenvolve a teoria do constitucionalismo.
} 
significativamente aumentado e apoiado em recursos próprios, o que promoveria a tendencial convergência das condições de vida no espaço da União, pois os recursos atualmente disponíveis a nível europeu no domínio social representam apenas 0,3\% dos gastos totais efetuados pelos Estados-Membros nessa área, o que acarreta um evidente descompasso entre as expectativas dos cidadãos e a capacidade da União de lhes responder. A União falaria a uma só voz em todas as questões de política externa e de defesa, bem como na gestão das fronteiras, nas políticas de asilo, na luta contra o terrorismo. O Mecanismo Europeu de Estabilidade tornar-se-ia no Fundo Monetário Europeu - estaria sujeito ao controlo do Parlamento Europeu e assumiria novas responsabilidades a fim de prestar apoio ao Banco Europeu de Investimento na mobilização do financiamento para estimular o investimento em toda a Europa.

Após um amplo debate - que se realizou à escala europeia nos últimos meses e no qual participaram o Parlamento Europeu, os parlamentos nacionais, as autoridades locais e regionais e a sociedade civil em geral - o Presidente Jean-Claude Juncker apresentou as suas considerações por ocasião do discurso sobre o estado da União ${ }^{5}$, em setembro de 2017, contribuindo assim para que o Conselho Europeu chegue às suas primeiras conclusões no final do ano de 2017 e decida sobre as medidas a adotar ao longo do período que precede as eleições para o Parlamento Europeu, em junho de 2019.

Claro que o desfecho também depende dos resultados eleitorais e da conformação de poder em França e Alemanha - não pode ser de outra forma. Não propriamente por conta da narrativa do "diretório franco-alemão" - que, em certa medida, desresponsabiliza os restantes Estados-Membros -, mas porque cerca de $40 \%$ de tudo o que se constrói a partir do orçamento da União é dinheiro do contribuinte francês ou alemão. Não é da mais elementar coerência que quem mais paga tenha uma palavra a dizer? De qualquer forma, os cidadãos europeus dos restantes Estados-Membros não podem estar alheios à definição do seu futuro - por isso precisam conhecer as

\footnotetext{
5 “Discurso sobre o Estado da União 2017”, Jean-Claude Juncker, acesso em dezembro 8, 2017, http:// europa.eu/rapid/press-release_SPEECH-17-3165_pt.htm.
} 
propostas e pressionar os decisores políticos no sentido das melhores escolhas. A União Europeia não é feita por extraterrestres - são os nossos representantes que lá estão: no Parlamento, no Conselho, na Comissão.

O debate em curso revela que as instituições europeias finalmente despertaram para a necessidade de tratar as causas do populismo e não os seus efeitos. As reformas exigíveis na União Europeia inserem-se numa problemática mais alargada que é aquela de saber até onde a globalização é suportável... até onde nós a conseguimos conduzir sem comprometer a nossa própria sobrevivência. Hoje temos consciência de que a globalização tem limites. E que se não compensarmos os excluídos da globalização - ou seja, os milhões de trabalhadores dos países industrializados que perderam o emprego e a esperança no futuro dos seus filhos - o protecionismo está ao virar da esquina. Isto porque ninguém vive sem futuro. E porque como sabiamente explicou Danilo Zolo em Sulla paura o medo é a pulsão elementar do ser humano.

Por mais que nos custe enquanto herdeiros das revoluções liberais, o que fenómenos como Brexit e Trump têm demonstrado é que em situações-limite, os eleitores preferem a segurança à liberdade. E por isso a segurança, desde aquela que se prende com a segurança física até a segurança social, corresponde a um valor essencial da democracia e da própria dignidade humana. Nesta medida, o grande desígnio da política nos dias que correm deve ser, tanto quanto possível, a redução do medo - pois o poder e o medo estão em estreita relação. Não há aqui qualquer apologia a uma deriva securitária, mas sim a recondução do valor segurança, enquanto redução da incerteza, a um axioma antropológico em face do populismo.

Tudo se torna mais difícil porque os cidadãos europeus (do norte e do sul, das economias mais e menos robustecidas) anseiam por coisas distintas e por vezes contraditórias entre si. Ou seja, a desconfiança entre o norte e o sul da Europa provoca resistências e o impasse na zona euro. Como então criar um espaço político que os reconcilie e promova compromissos entre visões porventura divergentes para a Europa? Como criar um espaço de vida partilhada que permita a escolha entre distintas alternativas políticas para a União, em detrimento da alternativa preguiçosa

${ }^{6}$ Cfr. Danilo Zolo, Sulla paura. Fragilità, agressività, potere (Feltrinelli: Milano, 2011). 
entre ser contra ou a favor da integração (Brexit)? Não é certamente empresa fácil mas tão pouco impossível. Bem vistas as coisas, as divergências entre o norte e o sul da Europa também se reproduzem no interior dos distintos Estados-Membros - e temos sabido geri-las/acomodá-las democraticamente.

Ademais, a solução está amplamente estudada nas obras de Ulrich Beck e Jürgen Habermas. E ela exige uma prática diferente i) dos governos dos EstadosMembros (que se escudam no discurso do défice democrático europeu para se desresponsabilizarem dos destinos da União Europeia), ii) dos meios de comunicação social (que podem contribuir decisivamente para a abertura recíproca das opiniões públicas nacionais, relatando as posições/controvérsias políticas que os temas europeus provocam noutros Estados-Membros), iii) dos partidos políticos nacionais (que, no intuito de ganhar eleições, semearam os ventos da segregação entre a política nacional e a política europeia e agora colhem a tempestade do populismo e da xenofobia).

Apesar da existência de um património matricial comum - democracia, direitos fundamentais, Estado de direito - o certo é que os cidadãos europeus não se conhecem uns aos outros. Por isso é preciso investir no seu conhecimento recíproco - algo que nunca se vai alcançar com a mera consulta à internet...esta pode ajudar na circulação de informações mas tem evidentes limitações na era das ditas "pósverdade" e "pós-democracia". Eduardo Prado Coelho dizia que a grande tarefa de uma política cultural europeia a sério devia ser a tradução. Mas a tradução no sentido amplo do termo: não apenas traduzir textos, mas traduzir mentalidades, formas de comportamento. Traduzir no sentido de "conduzirpara nós", pois só nos identificamos com aquilo que conhecemos ${ }^{7}$. Ou se quisermos ir à origem etimológica, traduzir do latim traducĕre - que significa transportar, transferir, composto por "trans" (para além) e "ducĕre" (conduzir).

Numa obra intitulada "Um ensaio sobre a Constituição da Europa", Jürgen Habermas explica que no início da integração europeia a força civilizadora desta

\footnotetext{
${ }^{7}$ Cfr. Eduardo Prado Coelho, "Unidos na diversidade?", in Portugal no futuro da Europa, coord. Paula Moura Pinheiro (Lisboa: Gabinete em Portugal do Parlamento Europeu, 2006), 75.
} 
inovação manifestou-se sobretudo na pacificação de um continente ensanguentado. Mas nos dias que correm, tal força civilizadora manifesta-se na luta pela construção de capacidades de ação política diante dos constrangimentos sistémicos de uma sociedade globalizada. O acolhimento da cidadania europeia, a referência expressa a um interesse geral europeu, assim como o reconhecimento de personalidade jurídica própria à União Europeia a partir do Tratado de Lisboa de 2009, tudo isso confirmaria, segundo Habermas, a ideia desenvolvida pelo Tribunal de Justiça da União Europeia segundo a qual os Tratados constitutivos correspondem à base jurídica de uma comunidade política europeia (EU polity) ${ }^{8}$.

Neste sentido, Habermas distingue três elementos basilares que têm de encontrar expressão em qualquer comunidade política democrática: i) a constituição de uma comunidade de pessoas jurídicas, numa associação de cidadãos livres e iguais em direitos; ii) a repartição de competências no âmbito de uma organização que garanta, através de meios administrativos, a capacidade de ação coletiva dos cidadãos associados; iii) um horizonte de vida partilhado, no qual se pode formar, comunicativamente, uma vontade coletiva. As duas primeiras componentes dizem respeito aos direitos fundamentais e à organização jurídico-constitucional do poder, enquanto a terceira corresponderia a um contexto político-cultural necessário, em termos funcionais, para a formação de opinião e vontade democráticas e a legitimação do exercício do poder.

É este contexto político-cultural que está a ser forjado atualmente na Europa - sobretudo porque as soluções de economic governance adotadas para fazer frente à crise originariamente financeira têm fortes elementos de ação política. Alguém poderia imaginar, há alguns anos, que os orçamentos democraticamente aprovados pelos parlamentos nacionais dos Estados-Membros da União Europeia teriam de ser previamente submetidos às instituições europeias para fins de apreciação e acomodação à vontade igualmente legítima dos restantes democracias europeias? Tem sido assim desde a introdução do chamado Semestre Europeu.

Por isso temos defendido que o aprofundamento da integração económica por conta da crise financeira conduz necessariamente à convergência política na União

${ }^{8}$ Cfr. Jürgen Habermas, Um ensaio sobre a Constituição da Europa (Lisboa: Edições 70, 2012), 82. 
- ou seja, ao desenvolvimento de uma União política - e questiona a relação entre a política nacional e a política europeia, provocando uma alteração na balança de poderes federativos na União. Tal problemática deve ser equacionada em termos jurídico-políticos numa nova perspetiva. Isto demanda um esforço teorético no sentido de delinear um caminho para tal União política, pois se não for o caminho que os europeus conseguirem consensualizar, será aquele que a força bruta lhes impuser - como ensinava Jean Monnet -, porventura hoje travestida nas ditas "matrizes comunicativas anónimas" de que fala Günter Teubner, reconhecidas por mercados financeiros, comunicação social, movimentos religiosos, risco, etc.

Num ano em que houve eleições em vários Estados-Membros, o debate sobre o futuro da Europa - e, muito especialmente, o reforço da proteção social prosseguido pelas instituições europeias - corresponde a uma estratégia política tendente a travar a adesão a movimentos nacionalistas/extremistas/populistas. Como explica Rui Tavares, esta é, definitivamente, a grande ameaça ao projeto europeu. Não é a crise do euro - porque, por enquanto, resolver os problemas do euro é ainda muito mais simples e bem mais provável do que caminhar para o colapso da moeda comum. Da mesma forma, o terrorismo não vai destruir Schengen - porque gerir o encerramento de fronteiras, com todo o esforço político, militar e infra-estrutural que tal implica, resultaria num dispêndio de recursos e energia muito superior ao de aperfeiçoar Schengen. Tão pouco a crise migratória vai destruir a União Europeia - porque os europeus sabem muito bem como reinstalar e integrar populações de refugiados, fizeram-no muitas vezes no passado. E nem mesmo o Brexit e seu anunciado "efeito domino" ameaça a existência da União Europeia - pois o Brexit é sobretudo um problema britânico, um problema existencial que pode provocar a cisão do Reino Unido enquanto tal, conduzindo à independência da Escócia e à instabilidade na Irlanda do Norte. Assim, o verdadeiro inimigo da integração europeia é (continua a ser) o fascismo. A União sempre foi o alvo do mais puro ódio dos fascistas e seus herdeiros - porque ela surge como uma resposta antifascista ao colapso do estado de direito no período entre as duas guerras mundiais?.

\footnotetext{
${ }^{9}$ Cfr. Rui Tavares, "O fim do «fim da Europa»", in União Europeia: reforma ou declínio, coord. Eduardo Paz
} 
Por isso o sociólogo alemão Ulrich Beck explicava que, apesar das suas imperfeições, a União Europeia tem inúmeras conquistas a apresentar - e a maior delas foi ter convertido inimigos em vizinhos. Muitas das conquistas da União Europeia tornaram-se tão óbvias que só repararíamos nelas se deixassem de existir - e talvez por isso alguns europeus estejam a abdicar da integração de forma tão leviana, com consequências nefastas para si próprios, para as gerações vindouras e para o resto do mundo ${ }^{10}$. Os Pais Fundadores da União Europeia acreditavam que o mercado comum seria um instrumento de transformação não só económico mas também psicológico. Por isso submeteram a uma autoridade administrativa comum todo um setor económico - o do carvão e do aço - porquanto indispensável à realização da guerra. Como sabiamente explicava Freud, a Europa não estava - como ainda não está - livre de uma erupção de bestialidade coletiva: a sua cultura e civilização são como uma fina camada sempre em risco de ser perfurada, a qualquer momento, pelas forças destrutivas do mundo subterrâneo ${ }^{11}$.

Se me é permitida uma nota pessoal-e julgo que o momento decisivo para a integração europeia o autoriza - diria que nasci no Brasil porque meus bisavós italianos tiveram de fugir à guerra, à fome e à miséria que assolaram o continente europeu no decorrer do séc. $\mathrm{XX}$. Conheço as dores dos refugiados de guerra. Não é por outra razão que me tenho dedicado ao estudo e divulgação da cultura jurídica da integração europeia. Mas é também para que meu filho de 18 anos possa optar por estudar Música, se assim o desejar, nas universidades alemãs (e gratuitamente), ou permanecer, como ele prefere, no Portugal que o viu nascer. Ou seja, sou pela integração europeia porque acredito na liberdade: de pensamento, de escolha e de circulação. Eu e mais de dois terços dos europeus que veem a União Europeia como um lugar de estabilidade num mundo conturbado, ou os 70\% dos cidadãos da área do euro que apoiam a moeda comum.

Mas isto não é suficiente, porque como explica o Livro Branco, a confiança dos cidadãos na União, tal como nas autoridades nacionais, tem decrescido. Por isso as

Ferreira (Lisboa: Nova Vega, 2016),443-445.

${ }^{10}$ Cfr. Ulrich Beck, A Europa alemã. De Maquiavel a "Merkievel": estratégias de poder na crise do euro (Lisboa: Edições 70, 2013), 26.

${ }^{11}$ Cfr. Stefan Zweig, O mundo de ontem: recordacõoes de um europeu (Porto: Assírio \& Alvim, 2014), 22. 
autoridades europeias e nacionais têm de desenvolver uma comunicação afetiva com os cidadãos europeus - que comunique com as preocupações das pessoas, que crie empatia e fomente a identidade europeia. Os cidadãos ignoram em que medida a União afeta a sua vida quotidiana - e que mais da metade das normas que nos regem nos distintos Estados-Membros têm origem nas instituições europeias.

É assim, porventura, porque as autoridades nacionais tendem a "europeizar" as desgraças e "nacionalizar" os sucessos. Mas basta que os cidadãos abram o frigorífico - para aquilo que é mais elementar à sua sobrevivência - e lá está a União: na livre circulação de mercadorias, na segurança alimentar, no controlo dos produtos químicos... Por isso urge desenvolver uma espécie de "campanba de alfabetização para a cidadania europeia" - como dizia Ulrich Beck - e aqui a Academia tem um grande contributo a dar.

É este o futuro que desejo para mim própria, para o meu filho e para a minha União. 



\title{
O afastamento de um cidadão da União Europeia por razões de ordem pública e segurança pública: implicações no desenvolvimento da cidadania europeia
}

\author{
Amélie Fernandes* \\ RESUMO: O afastamento de um cidadão da União Europeia por raz̃oes de ordem pública e segurança pública regulado \\ nos artigos $27 .^{\circ}$ e 28. da Diretiva (CE) 2004/38 é uma medida com caráter excecional. Nesse sentido, o afastamento \\ de um cidadão da União do Estado-Membro (de acolbimento) onde tenha adquirido um direito de residência permanente \\ é suscetivel de colocar em causa a unidade da evolução da cidadania da União e o efeito prático do espaço de liberdade, \\ segurança e justiça. A jurisprudência do Tribunal de Justiça da União patente nos acórdãos P. Tsakouridis e P.I. é um \\ exemplo significativo e intrigante de como os critérios relativos às medidas de afastamento poderão minar o sentido prático \\ da cidadania da UE.
}

PALAVRAS-CHAVES: cidadania da UE - afastamento - ordem pública - segurança pública - direito de residência.

ABSTRACT: The expulsion of a citizen of the European Union on grounds of public policy and public security regulated by Articles 27 and 28 of Directive (EC) 2004/38 is an exceptional measure. Indeed, the expulsion of a citizen of the Union who has acquired a permanent right of residence from his or hers host Member State is likely to call into question the unity of the evolution of Union citizenship and the practical effect of the area of freedom, security and justice. The case law of the European Court of Justice in the judgments in P. Tsakouridis and P.I. is a significant and intriguing example of how the criteria for expulsion measures could be interpreted and undermine the practicality of EU citizenship.

KEYWORDS: EU citizenship - expulsion - public order - public security - right of residence.

\footnotetext{
* Mestre em Direito da União Europeia e pós-graduanda em Ciências Políticas na Universidade do Minho.
} 


\section{A cidadania da União: de uma cidadania migrante para uma cidadania de direitos}

A presente investigação de mestrado tem por objeto o afastamento de um cidadão da União Europeia por razões de ordem pública e segurança pública: implicações no desenvolvimento da cidadania europeia. Nesse sentido, a investigação tem por escopo o estudo de um dos limites colocados à cidadania da União Europeia, a saber: as medidas de afastamento de um cidadão da União com fundamento em razões de ordem pública e segurança pública nos termos consagrados na Diretiva 2004/38.

A cidadania europeia foi instituída pelo Tratado de Maastricht em 1992, encontrando-se hoje consagrada nos artigos $20 .^{\circ}$ a $25 .^{\circ}$ do Tratado sobre o Funcionamento da União Europeia (TFUE), nos artigos 39. a $46 .^{\circ}$ da Carta dos Direitos Fundamentais da União Europeia (CDFUE) e na Diretiva 2004/38. Nos termos dos Tratados, "é cidadão da União qualquer pessoa que tenha a nacionalidade de um Estado-Membro" (artigo 20. TFUE). Inicialmente, a cidadania da União teve como intuito conceder um conjunto de direitos civis, políticos e sociais aos nacionais de um Estado-Membro que estivessem a exercer o seu direito de livre circulação. Ora, a entrada em vigor da CDFUE, assim como a consagração do espaço de liberdade, segurança e justiça (ELSJ), o qual pretende garantir a segurança no espaço da União nomeadamente através da cooperação entre os Estados-Membros em matéria civil, penal e policial, vieram reforçar, pelo menos na generalidade dos casos, os direitos associados ao estatuto de cidadão da União.

A Diretiva 2004/38 1 relativa ao direito à livre circulação e residência dos cidadãos da União e dos membros das suas famílias no território dos Estados-Membros foi um dos principais instrumentos de direito derivado que orientou o presente estudo na medida em consagra condições e limitações ao exercício desse direito. A diretiva tem por objetivo facilitar o exercício desse direito. Nesse sentido, consagra um

\footnotetext{
${ }^{1}$ Diretiva (CE) 2004/38 do Parlamento Europeu e do Conselho de 29 de abril de 2004, relativa ao direito de livre circulação e residência dos cidadãos da União e dos membros das suas famílias no território dos Estados-Membro.
} 
direito de residência até três meses sem outras condições para além da titularidade de um documento de identificação válido. Para além de três meses de residência, o cidadão conserva o seu direito de residir desde que exerça uma atividade assalariada ou disponha de recursos suficientes para si e para a sua família de modo a não se tornar uma sobrecarga para a segurança social do Estado-Membro de acolhimento; ou esteja inscrito num estabelecimento de ensino reconhecido, e disponha de uma cobertura de seguro de doença; ou ainda, seja membro da família de um cidadão que reúne estas condições assim como as formalidades administrativas. Por último, o cidadão da União que tenha residido por um período consecutivo de cinco anos adquire o direito de residência permanente no Estado-Membro de acolhimento.

No entanto, o capítulo VI da Diretiva 2004/38 consagra algumas restrições ao exercício do direito de entrada e residência por razões de ordem pública, segurança pública e saúde publica, em particular nos artigos $27 .^{\circ}$ e $28 .^{\circ}$. Para além de requisitos gerais atinentes ao respeito pelo princípio da proporcionalidade e à apreciação casuística do comportamento da pessoa em questão, uma medida de afastamento não poderá ser tomada com base na existência de condenações penais anteriores. Caso o cidadão tenha residido no Estado-Membro de acolhimento nos 10 anos precedentes a uma medida de afastamento, a medida de afastamento só poderá ser justificada por "raz̃ôs imperativas de segurança pública". A Diretiva 2004/38 estabelece assim que quanto maior for o grau de integração do cidadão da União, avaliado através do período de tempo de residência no Estado-Membro de acolhimento, maior será o grau de exigência para a proteção contra o afastamento.

\section{Os acórdãos P. Tsakouridis e P.I.}

Os dois acórdãos P. Tsakouridis e P.I. ${ }^{2}$ versam sobre esta matéria, nomeadamente sobre o conceito de "razôes imperativas de segurança pública".

\footnotetext{
${ }^{2}$ Acórdão TJUE de 23 de novembro de 2010, Land Baden-Württemberg contre Panagiotis Tsakouridis, Processo. C- 145/09, EU:C:2010:708 e Acórdão TJUE de 22 de maio de 2012, P.I contra Oberbürgermeisterin der Stadt Remscheid, Processo C- 348/09, EU: C: 2012: 300.
} 
No caso subjacente ao acórdão $P$. Tsakouridis estava em causa um cidadão grego, nascido e residente na Alemanha que foi condenado a uma pena de prisão de seis anos e seis meses por ter praticado oito crimes de tráfico ilícito de estupefacientes em associação criminosa em quantidades significativas. Consequentemente, foi ordenada a perda do seu direito de entrada e residência do território alemão e afastamento em breve.

No quadro do acórdão P.I., estava em causa um cidadão de nacionalidade italiana residente na Alemanha condenado a uma pena privativa de liberdade de sete anos e seis meses por abuso sexual, coação sexual e violação de menor. Na sequência da condenação, foi ordenado o seu afastamento do território alemão.

Resumidamente, em ambos os casos, os órgãos jurisdicionais de reenvio pretendiam saber se os factos na origem de cada um dos casos seriam suscetíveis de integrar o conceito de "razões imperativas de segurança pública" e, em consequência, poderiam conduzir ao afastamento dos cidadãos da União em causa para os seus Estados-Membros de origem.

O objetivo da investigação foi a análise da resposta que o Tribunal de Justiça forneceu a ambos os casos. Em termos gerais, o Tribunal de Justiça entendeu que ambos os casos poderiam integrar o conceito de "rąõoes imperativas de segurança pública" se a avaliação do comportamento pessoal e da situação pessoal do interessado e a sua gravidade preenchessem um conjunto de critérios mencionados.

\section{Implicações das medidas de afastamento para a cidadania da União}

Os critérios que o Tribunal de Justiça forneceu para a interpretação daquele conceito e o resultado que essa interpretação é suscetível de conduzir são intrigantes, quer do ponto de vista de jurisprudência anterior, quer do ponto de vista do aprofundamento do sentido da cidadania da União como uma cidadania de direitos. Assim porque a interpretação feita pelo Tribunal de Justiça aproximou os conceitos

de "razõos graves de ordem pública" e de "raz̧ão imperativa de segurança pública". Ora, o segundo corresponde a uma realidade bem mais grave e restrita. A leitura conjunta 
desses conceitos conduz a que possam ser integrados mais motivos suscetíveis de conduzir ao afastamento de cidadãos da União por razões imperativas de segurança pública do que inicialmente previsto na diretiva.

Por isso, propusemo-nos com a investigação analisar as implicações desta jurisprudência do Tribunal de Justiça no desenvolvimento da cidadania da União, analisando o processo legislativo que conduziu à consagração do afastamento de cidadãos da União na Diretiva 2004/38. Nos trabalhos preparatórios da diretiva não estava prevista a possibilidade de afastar cidadãos que tivessem adquirido um direito de residência permanente ${ }^{3}$. Realizamos também um estudo das conclusões do Advogado-Geral em ambos os processos, as quais inclusivamente propuseram respostas diferentes daquelas que o Tribunal de Justiça forneceu às questões prejudiciais. Por outro lado, ao longo dos trabalhos de investigação tivemos a curiosidade de perceber qual veio a ser, na prática, o impacto daquela jurisprudência em relação às medidas de afastamento depois das respostas fornecidas pelo Tribunal de Justiça. Por isso, fomos investigar qual foi a decisão do juiz nacional alemão ao caso P.I. que, efetivamente, com base nas respostas fornecidas pelo Tribunal de Justiça às questões prejudiciais, decidiu manter a decisão de afastamento.

Uma das principais implicações no desenvolvimento da cidadania da União é a diferença de tratamento que resulta entre os cidadãos nacionais do EstadoMembro e os cidadãos com estatuto de residente permanente no Estado-Membro de acolhimento. $\mathrm{O}$ cidadão residente passa a ter o seu direito fundamental à livre circulação e residência limitado e assim sendo facilmente a partir do momento onde é considerado criminoso estrangeiro.

Por outro lado, tentamos medir as implicações e o effet utile das medidas de afastamento tal como descritas nos casos P. Tsakouridis e P.I. na perspetiva do ELSJ sem fronteiras internas. Que segurança para os cidadãos da União é garantida se um cidadão considerado perigoso e que coloca em causa a segurança pública na

\footnotetext{
${ }^{3}$ Proposta de diretiva do Parlamento Europeu e do Conselho relativa ao direito à livre circulação e residência dos cidadãos da União e membros das suas famílias no território dos Estados-Membros [COM (2001) 257 final - 2001/0111(COD)] de 25.09.2011.
} 
Alemanha é expulso para o seu Estado-Membro de origem, Grécia, e continua a poder reincidir circulando livremente pelos Estados-Membros? Na nossa opinião, não haverá uma verdadeira utilidade. No máximo, o cidadão da União afastado de um Estado-Membro de acolhimento verá o seu direito de residência recusado num próximo Estado-Membro de acolhimento ou continuará a circular livremente.

Por último, é preocupante assistir ao desenvolvimento da cidadania da União onde é permitido a adoção de medidas de afastamento de quem é europeu e faz parte dos Estados-Membros. É verdade que não é todos os dias que as administrações dos Estados-Membros se deparam com casos de expulsões de quem é português, espanhol, francês, grego ou italiano. Mas é nos casos excecionais como esses que conseguimos perceber e ver testados os limites desse sistema e na presente investigação conseguimos retirar como conclusões que a cidadania da União e o direito à livre circulação e residência funciona de acordo com várias velocidades. Um dos seus limites poderá ser não cumprir a ordem pública, segurança pública ou valores fundamentais definidos pelo Estado-Membro de acolhimento, o que revela um "lado lunar ou oculto da cidadania da União"4.

\footnotetext{
${ }^{4}$ Alessandra Silveira, e Sophie Perez Fernandes, "O afastamento de um cidadão da União por "razões imperativas de segurança pública (ou o lado lunar da cidadania da União). Uma amostra da recente jurisprudência do Tribunal de Justiça", in Studi Giuridici Europei (Università degli Studi Europea di Roma: G. Giappichelli Editore, Torino 2015), 25.
} 


\title{
A conjuntura pós-2015 e o espaço de liberdade, segurança e justiça - nótula sobre os impactos ao nível da proteção internacional na União Europeia
}

\author{
Ana Maria Rodrigues*
}

RESUMO: A partir de 2015, a politica europeia de asilo viu-se confrontada com uma situação de excecionalidade originada pelo enorme afluxo de migrantes e pessoas em necessidade de proteção internacional - à qual parece não ter sabido responder. Este artigo pretende lançar pistas sobre o sentido da evolução securitizante a que se tem assistido nos dois últimos anos, o que pode comprometer o respeito pelos direitos fundamentais e pelas regras do estado de Direito, seja por parte dos Estados-Membros, seja por parte da própria União Europeia.

PALAVRAS-CHAVE: proteção internacional - securitização - gestão de fronteiras - asilo - externalização das admissões.

ABSTRACT: From 2015 onwards, the European asylum policy was faced with an exceptional situation of influx of persons in need of international protection and other migrants, to which it displayed difficulties in reacting. This article sheds light on the apparent securitisation of the last couple of years, which can endanger the compliance with fundamental rights and the rule of law, both by the European Union Member-States and by the European Union itself.

KEYWORDS: international protection - securitization - border management - asylum - extra-territorial admissions.

\footnotetext{
* Doutoranda em Ciências Jurídicas Públicas na Universidade do Minho. Membro não Doutorado do Centro de Estudos em Direito da União Europeia - CEDU.
} 
1. A adequada implementação do espaço Schengen, aliada a uma série de diferentes fatores que fizeram intensificar nos últimos anos os movimentos para a Europa - dos quais podemos destacar a situação resultante da intervenção militar ocidental no Afeganistão e no Iraque, por um lado, a Primavera Árabe, com as consequentes convulsões na Líbia e na Síria, por outro, e ainda, mais recentemente, a posterior intensificação do conflito interno na Síria e a Acão terrorista pulverizada do grupo extremista Daesh - foram conduzindo progressivamente a uma maior demanda protecionista das fronteiras externas da União Europeia (doravante, UE ou União), conduzindo também, designadamente, a uma cada vez maior aposta em mecanismos de externalização do controlo migratório ${ }^{1}$, que se vinha anunciando desde o dealbar do milénio.

Nesse contexto, o ano de 2015 veio pôr à prova, de uma forma extraordinária, a política de gestão de fronteiras da UE e, em especial, o sistema europeu comum de asilo. De facto, e com particular acuidade a partir da segunda metade de 2015, assistiu-se a uma situação de enormes afluxos de migrantes (lato sensu) ao território da $\mathrm{UE}^{2}$, a maioria dos quais em necessidade de proteção internacional, naquela que ficou já crismada como uma "crise migratória e de refugiados sem precedentes"3. Se é verdade que, desde o pico de chegadas verificado no segundo semestre de 2015 até hoje, os números de entradas irregulares no território da União baixaram

\footnotetext{
${ }^{1}$ Referimo-nos, nomeadamente, às condições de concessão de vistos, às políticas de regresso e de readmissão, ou às interceções por mar. Para uma análise de algumas destas facetas, vd. "Facilitating Mobility and Fostering Diversity: Getting EU Migration Governance to Respect the Human Rights of Migrants", François Crépeau e Anna Purkey, acesso em setembro 5, 2017, https://www.ceps.eu/ system/files/LSE $\% 20$ No\%2092\%20Facilitating\%20Mobility.pdf, 10 e ss.

${ }^{2}$ De acordo com o Alto Comissariado das Nações Unidas para os Refugiados (ACNUR), mais de 60 milhões de pessoas foram deslocadas em 2015, o que corresponde à situação mais gravosa verificada desde a Segunda Guerra Mundial. Os Estados-Membros da UE, em comparação com outros países - designadamente os países limítrofes das zonas de origem das pessoas deslocadas - sentiram os efeitos desta situação de forma muito mitigada. Tratou-se (e trata-se), ainda assim, de um número extraordinariamente superior aos números verificados em anos anteriores. Para uma perspetiva dos números de chegadas a território da UE, vd. Nuno Piçarra, "A União Europeia e "a crise migratória sem precedentes": crónica breve de uma ruptura do Sistema Europen Comum de Asilo", Revista Electrónica de Direito Público 3,2 (novembro 2016): 4, nota 2.

${ }^{3}$ Por facilidade, e brevitatis causa, utilizaremos, ao longo do texto, a elipse 'crise sem precedentes' para fazer menção a esta conjuntura, que preferimos à comummente usada 'crise de refugiados'.
} 
significativamente, este abaixamento parece ser muito dificilmente sustentável quer em termos práticos quer, potencialmente, pelo crivo jurisprudencial. Tratou-se, de facto, de um abaixamento originado, artificialmente, pelo entendimento ${ }^{4}$ com a Turquia para travar as travessias irregulares e o contrabando de pessoas entre a costa turca e a costa grega e pelo fecho de fronteiras ao longo da rota dos Balcãs.

Concomitantemente, acontecimentos como os ataques terroristas de novembro de 2015 em Paris, seguidos dos de Bruxelas, Nice e Berlim, em 2016, vieram trazer, às populações dos diversos Estados-Membros, um sentimento de insegurança que não parece ter sido indiferente à forma como se reagiu e se geriu a própria 'crise sem precedentes' 5 .

2. O artigo 67. ${ }^{\circ}$ do Tratado sobre o Funcionamento da União (TFUE) estabelece que a União desenvolve uma política comum em matéria de asilo, de imigração e de controlo das fronteiras externas que se baseia na solidariedade entre Estados-Membros e que é equitativa em relação aos nacionais de países terceiros. Concretizando, o artigo $78 .^{\circ}$ refere uma política comum em matéria de asilo, de proteção subsidiária e de proteção temporária, destinada a conceder um estatuto adequado a qualquer nacional de um país terceiro que necessite de proteção internacional e a garantir a observância do princípio do non-refoulement. Neste enquadramento, porém, a manutenção da ordem pública e a garantia da segurança nacional pertencem à esfera de competências de cada Estado-Membro.

Ora, aquele afluxo extraordinário de pessoas, associado ao aumento da sensação de insegurança das populações, parece ter levado os Estados-Membros e a própria União a uma redefinição da sua identidade e dos seus valores, postergando tanto

\footnotetext{
${ }^{4} \mathrm{~A}$ forma jurídica deste entendimento não é muito clara, discutindo-se se se trata ou não de um acordo internacional e se foi celebrado pela UE ou pelos seus Estados-Membros. O Tribunal Geral da União veio já pronunciar-se, em 3 casos semelhantes, no sentido de que, apesar de se intitular Declaração Conjunta UE - Turquia, e de ter sido publicitada na própria página que o Conselho Europeu partilha com o Conselho da União, se trataria antes de uma série de acordos paralelos celebrados pelos vários Estados-Membros com a Turquia (casos T-192/16, T-193/16 e T-257/16). Perdeu-se, assim, uma oportunidade de apreciar os próprios termos da Declaração e a sua possível ilegalidade.

${ }^{5}$ Para uma alusão a esta associação, vd. "The EU's Response to the Refugee Crisis: Taking Stock and Setting Policy Priorities", Sergio Carrera et al., acesso em setembro 5, 2017, https://www.ceps.eu/ system/files/EU\%20Response\%20to\%20the\%202015\%20Refugee\%20Crisis_0.pdf, 2.
} 
a partilha de responsabilidades e a solidariedade em matéria de concessão de proteção internacional como a assunção da necessidade de respeito pelos direitos fundamentais dos recém-chegados, e ainda intensificando a vigilância interna exercida, maioritariamente, sobre os não-cidadãos ou sobre os cidadãos de origem estrangeira ${ }^{6}$.

Desde 2015, uma série de iniciativas foram postas na agenda para reagir ao novo cenário. No que toca à gestão da 'crise sem precedentes', a ênfase tem sido posta no combate aos fluxos irregulares e na ideia de evitar abusos no acesso à proteção internacional (designadamente através daquilo a que se convencionou chamar o asylum shopping ${ }^{\nearrow}$, mais do que na concessão e garantia de efetiva proteção ${ }^{8}$. As duas iniciativas mais expressivas ${ }^{9}$ equivalem, em traços largos, a um programa ex novo de recolocação de requerentes de proteção internacional da Grécia e Itália ${ }^{10}$ para outros Estados-Membros, por um lado, e à Declaração conjunta UE-Turquia e outros acordos de readmissão, por outro. Assistiu-se ainda a uma cada vez maior banalização ${ }^{11}$ da detenção dos requerentes de asilo e - o que se revestirá porventura

\footnotetext{
${ }^{6} \mathrm{Vd}$. "The EU counter-terrorism policy responses to the attacks in Paris: Towards an EU security and liberty agenda", Didier Bigo et al., acesso em setembro 5, 2017, https://www.ceps.eu/system/files/ LSE81Counterterrorism.pdf, 12.

${ }^{7}$ Asylum shopping é expressão com que se convencionou caracterizar a tentativa de procurar protecção no Estado-Membro que ofereça condições mais favoráveis, no que toca, v.g., à duração do período de residência, à emissão de documentos de viagem, ao direito ao reagrupamento familiar ou à aquisição da nacionalidade, entre outros.

${ }^{8} \mathrm{Vd}$. "A new asylum policy for Europe?! - Opting for a rights-based approach and what this would mean", Dorothea Keudel-Kaiser et al., acesso em setembro 5, 2017, http://bim.lbg.ac.at/sites/files/ bim/attachments/a_new_asylum_policy_for_europe.pdf, 5 .

${ }^{9}$ Para uma visão panorâmica e análise crítica destas iniciativas, vd. Piçarra, "A União Europeia e "a crise migratória sem precedentes"”, 30 e ss.

${ }^{10}$ As Decisões (UE) 2015/1523, de 14 de setembro, e 2015/1601, de 22 de setembro de 2015, ambas do Conselho, introduziram um desvio à regra, ditada subsidiariamente pelo sistema de Dublin (Regulamento 604/2013 do Parlamento Europeu e do Conselho, de 26 de junho, ou mais simplesmente Regulamento Dublin III), de que o Estado-Membro responsável por apreciar o pedido de proteção internacional é o Estado-Membro de primeira entrada do requerente. Com a duração prevista de 24 meses, até setembro de 2017, o programa de recolocação desenhado em 2015 mostrou, até à data, ser pouco eficiente (designadamente em virtude dos critérios de elegibilidade previstos), por um lado, e facilmente incumprível, por outro.

11 Banalização reforçada, designadamente, pela promoção desta medida por parte das próprias instituições europeias - cf. declarações à imprensa do Comissário Europeu para as Migrações, Dimitris
} 
de maior gravidade, porquanto potencialmente violadora de disposições cogentes a nível internacional, bem como do acervo da União - à normalização dos chamados pushbacks $^{12}$ nas fronteiras terrestres e em águas internacionais.

Às medidas tomadas ao nível da UE juntam-se várias outras tomadas a nível nacional que materializam igualmente uma ideia de normalização de um estado de exceção; entre estas encontram-se a suspensão de Schengen e a concomitante reposição de controlo de fronteiras entre Estados-Membros ${ }^{13}$ ou a declaração de estado de emergência prolongado, que vigorou em França a partir de novembro de 2015), entre vários outros exemplos.

3. Entretanto, e num plano não tão distinto como desejável (porque igualmente atinente à gestão das fronteiras externas), várias medidas de prevenção do terrorismo foram apresentadas como urgentes e necessárias no rescaldo dos atentados terroristas em França, na Bélgica e na Alemanha, após prolongado e controverso debate e apesar de manifestamente controversas e com reconhecido potencial de ilegalidade ${ }^{14}$.

A escalada da securitização a que se assistiu após 2001 representou um marco que implicou uma verdadeira mudança de paradigma ${ }^{15}$ e trouxe já muitas das alterações que, tendo perdido força entretanto ${ }^{16}$, agora recrudescem - como o endurecimento do discurso político, a proliferação simultânea de instrumentos político-legislativos em matéria de gestão de fronteiras, asilo e imigração, o progressivo fecho de fronteiras e consequente afunilamento das opções de entrada regular no território, a criação de novos mecanismos de vigilância, o enfraquecimento da qualidade da

Avramopoulos, de 2 de março de 2017 (disponíveis aqui: "EU wants rejected migrants, including minors, locked up", Nikolaj Nielsen, acesso em setembro 5, 2017, https://euobserver.com/migration/137088). 12 Perdoe-se-nos o emprego do anglicismo, que usamos por facilidade discursiva - o termo engloba variados tipos de repulsão, interceção e não-admissão ao território.

${ }^{13}$ Designadamente por parte da Dinamarca, da Suécia, da Áustria ou da Alemanha.

${ }^{14}$ Cf. "The EU counter-terrorism policy responses to the attacks in Paris: Towards an EU security and liberty agenda", Didier Bigo, 8 e ss.

${ }^{15}$ Alguns autores veem esta mudança de paradigma sob a ótica da renacionalização das políticas. $V d$., a este propósito, Fabrizio Tassinari, "The Disintegration of European Security: Lessons from the Refugee Crisis", Prism 6,2 (2016): 71-83.

${ }^{16}$ Em boa parte, em virtude da aplicação dos princípios do Estado de Direito e da proteção de direitos fundamentais ao nível europeu. $V d$., nesse sentido, Philippe Delivet, "The European Union and the fight to counter terrorism”, European Issues 386 (2016): 4. 
proteção dos requerentes de asilo, entre outras. Nestes últimos anos, porém, não está ainda claro se a atuação dos Estados-Membros e das várias instituições europeias a este propósito significa apenas uma intensificação da securitização que já se vinha sentindo nos últimos anos - ou mesmo décadas ${ }^{17}$ - e de que é devedora a expressão 'fortaleza Europa' aplicada a este contexto, ou se, ao contrário, esta atuação está a ir (ou irá) mais além ${ }^{18}$, com o impacto que isso possa ter ao nível do respeito pelos princípios fundadores da $\mathrm{UE}^{19}$. Esta possibilidade é tanto mais tangível quanto, desta feita, e ao contrário do pós-2001, são agora duas as circunstâncias que concorrem para esta tendência securitizante - por um lado, a vaga de atentados terroristas em solo europeu e, por outro, o extraordinário afluxo de refugiados e outros migrantes às fronteiras externas da União ${ }^{20}$. Ou seja, as matérias relativas ao asilo e migrações vão-se paulatinamente movendo ${ }^{21} \mathrm{da}$ esfera da política de justiça e assuntos internos para a esfera da política externa, de segurança e defesa.

O Tribunal de Justiça da UE (TJUE) terá aqui um papel preponderante, tanto em relação às novas medidas tomadas como relativamente ao acervo pré-existente. Em paralelo, o Tribunal Europeu dos Direitos Humanos (TEDH), que estabeleceu já importantes referenciais para a proteção dos direitos fundamentais, terá de avaliar se estes têm efetivamente sido cumpridos e, se não, com que base. Importará, nos próximos tempos, perceber se estamos, de facto, perante um reenquadramento não

\footnotetext{
${ }^{17}$ Havendo quem refira que a securitização das políticas europeias de asilo e imigração teve impulsos antes mesmo da sua incorporação no terceiro pilar da UE, no Tratado de Maastricht. Nesse sentido, vd. "Did 9/11 Matter?: Securitization of Asylum and Immigration in the European Union in the Period from 1992 to 2008", Dace Schlentz, acesso em setembro 5, 2017, http://repository.forcedmigration. org/pdf/?pid=fmo:5570, 4.

${ }^{18} \mathrm{Na}$ medida em que, ao contrário do pós-2001, são agora duas as circunstâncias que concorrem para este tendência securitizante - por um lado, a vaga de atentados terroristas em solo europeu e, por outro, o extraordinário afluxo de refugiados e outros migrantes às fronteiras externas da União.

${ }^{19}$ Importa aqui referir que, para além dos princípios do Estado de Direito e de respeito pelos direitos fundamentais, expressamente consagrados no Tratado da União (TUE) e no TFUE, esta mudança de paradigma - a existir - pode contender com a própria liberdade de circulação de pessoas, enquanto liberdade conferida pelo TFUE e pelo acervo Schengen.

${ }^{20} \mathrm{Vd}$. "EU Refugee Policy in Crisis: blockades, decisions, solutions", Petra Bendel, acesso em setembro 5, 2017, http://library.fes.de/pdf-files/wiso/13536.pdf, 5 e ss.

${ }^{21}$ Como alerta Petra Bendel, "EU Refugee Policy in Crisis: blockades, decisions, solutions", 6.
} 
só da migração, genericamente considerada, mas mesmo, e muito especialmente, da proteção internacional, afetando o acervo da UE e potencialmente princípios de direito cogente ao nível internacional, através da legitimação de políticas, normas e práticas controversas, por recurso ao discurso do medo $^{22} \mathrm{e}$ da necessidade de reforço do poder e controlo públicos.

${ }^{22}$ Sobre o uso do discurso do medo, of. Christopher Baker-Beall, "The Discursive Construction of EU Counter-Terrorism Policy: Writing the 'Migrant Other', Securitisation and Control', Journal of Contemporary European Research 5, 2 (2009): 188-206. 



\section{O Eurogrupo e o manto de secretismo}

\section{Andreia Barbosa*}

RESUMO: Apesar de o Eurogrupo ser capaz de criar um impacto gigantesco na vida da União Europeia, a sua atuação encontra-se coberta por um manto de secretismo que, a pretexto de uma invocada "informalidade", cria um efeito de opacidade. Em rota de colisão com o princípio da boa administração e em contraposição à ideia de necessária transparência e publicidade em todos os centros de decisão, no Eurogrupo não são assinadas atas ou documentos, não existem transcrições, minutas ou registos atinentes aos respetivos encontros, não foi criada, sequer, uma base de dados que agregue as "decisões" tomadas. A presente exposição assume, pois, o ensejo de contribuir para o estudo dos termos em que as exigências decorrentes dos princípios da boa administração, da transparência e da democracia devem valer também para o Eurogrupo e para avançar com algumas propostas para a concretização das mesmas.

PALAVRAS-CHAVE: Eurogrupo - informalidade - boa administração - transparência - democracia

ABSTRACT: Although the Eurogroup is capable of creating a huge impact on the life of the European Union, its work is surrounded in secrecy, which, on the pretext of invoked "informality", creates an opacity effect. In collision with the principle of good administration and contrary to the idea of transparency and publicity required in all decision-making centers, no documents are signed in the Eurogroup, there are no transcripts or registers relating the respective meetings and does not exist also a database that adds the taken "decisions". Thus, the purpose of this presentation is to contribute to the study of the terms under which the requirements arising from the principles of good administration, transparency and democracy must also apply to the Eurogroup and to come up with some proposals for their implementation.

KEYWORDS: Eurogrupo - informality - good administration - transparency - democracy

\footnotetext{
* Doutoranda em Ciências Jurídicas Públicas na Universidade do Minho. Membro não Doutorado do Centro de Estudos em Direito da União Europeia - CEDU.
} 


\section{Informal opacidade no Eurogrupo}

De acordo com o art. $1 .^{\circ}$, do Protocolo n. ${ }^{\circ} 14$, anexo ao Tratado sobre o Funcionamento da União Europeia (TFUE), e para o qual remete o art. 137. ${ }^{\circ}$, a reunião entre os Ministros dos Estados-Membros cuja moeda seja o euro deve ser feita de "maneira informal", ocorrendo apenas na medida do necessário, para debater questões relacionadas com as responsabilidades específicas que os Estados-Membros em causa partilham em matéria de moeda única. Sucede, no entanto, que não se concretiza em que é que essa informalidade se traduz. A prática tem demonstrado que a informalidade se reflete (i) nos termos em que as reuniões são feitas, ou seja, na tramitação procedimental, visto que, por exemplo, não existe qualquer regulamentação criada, que defina o procedimento a adotar, no sentido de, nomeadamente, garantir a intervenção de todos os intervenientes e de definir a ordem pela qual essas intervenções podem ser realizadas e a duração que poderão ter e (ii) nos termos em que as "decisões" são tomadas, concretamente, quanto à forma como são levadas ao conhecimento do público: é somente através das conferências de imprensa que o resultado das reuniões é apresentado ao público (e quando o são).

Ora, atenta a real relevância e a extensão que as reuniões do Eurogrupo assumem - competindo-lhe, designadamente, zelar por objetivos económicos que se prendem, por exemplo, com o desenvolvimento, investimento, comércio, produtividade, desemprego, disparidades internas e pobreza - parece-nos redutor considerá-lo um "mero fórum de discussão", que pode funcionar de "portas fechadas", apenas porque não tem base legal nos Tratados europeus. Na realidade, e desde logo, o Eurogrupo serve de canal pelo qual a Comissão e o Banco Central Europeu (BCE) adotam decisões sobre questões específicas

\footnotetext{
${ }^{1}$ Referimo-nos a "decisões" enquanto fruto das reuniões do Eurogrupo, ainda que tenhamos presente que, na realidade, a decisão formal, final e vinculativa sobre o assunto que esteja a ser tratado só terá lugar no dia posterior, na reunião do Ecofin. No entanto, estamos também cientes do facto de que as votações realizadas no Ecofin espelham o resultado da prévia reunião do Eurogrupo. A decisão final do Ecofin nasceu no Eurogrupo. Por isso, optamos aqui por "chamar as coisas pelo nome", privilegiando a respetiva componente prática, e referirmo-nos a "decisões" do Eurogrupo.

${ }^{2}$ Cfr. acórdão TJUE de 20 de setembro de 2016, Mallis e Mali, Processos apensos C105/15 P a C109/15 P, ECLI:EU:C:2016:702, considerando 47.
} 
atinentes ao próprio Mecanismo Europeu de Estabilidade. Ademais, o Eurogrupo é o berço das decisões do Ecofin; as decisões do primeiro constituem a antecâmera das do segundo. E mesmo no caso de as decisões do Ecofin se desviarem do que tiver sido "decidido" no Eurogrupo, continua a existir todo o interesse em saber em que termos é que a discussão sobre os assuntos em debate foi feita. Essa possibilidade, todavia, não existe ${ }^{3}$. Constata-se, pois, que a informalidade que resulta do art. 1. ${ }^{\circ}$, do Protocolo n. ${ }^{\circ}$ 14, significa, na prática, "opacidade", que é insuportável à luz do bem comum europeu e que potencia o estado de desintegração e de descrença que urge travar ${ }^{4}$.

A opacidade verificada nega aos cidadãos da União a possibilidade de terem conhecimento quanto aos termos em que a sua representação é feita na tomada das decisões que definem não só o presente de quem é e de quem está na União, mas também o futuro das gerações vindouras. Desconhecem-se as propostas em discussão, os votos apresentados, os conflitos de interesses surgidos e os compromissos concretamente assumidos, quando, pelo contrário, se deveria garantir as reais condições para formulação de vontades livres e esclarecidas. $\mathrm{Na}$ verdade, "onde não houver consciência cívica dos governados (ou a ideia de responsabilização individual pelo destino coletivo), toda a vivência democrática e o controlo do poder estão comprometidos's.

\footnotetext{
${ }^{3}$ A este propósito, o "DiEM25" (um movimento pan-europeísta) encontra-se a promover uma campanha pró-transparência, sob o lema Let Light In , tendo sido elaborada, nesse âmbito, uma petição, na qual constam as seguintes exigências: a transmissão integral e em direto das reuniões do Eurogrupo, do Conselho Europeu, do Conselho de Governadores do Mecanismo Europeu de Estabilidade, e do ECOFIN, com a subsequente publicação oficial das transcrições de todas as referidas reuniões; a gravação integral de cada reunião do Conselho do BCE, a ser publicada três semanas depois da conclusão de cada reunião ordinária e que as respetivas transcrições sejam publicadas num período de dois anos; a elaboração de uma lista exaustiva identificando os lobbies que exercem pressão em Bruxelas, devendo também ser feito um registo de cada uma das suas reuniões com entidades eleitas ou não eleitas da UE; e, ainda, a publicação eletrónica de todos os documentos relacionados com as negociações do Tratado Transatlântico de Investimento, com transparência total em todos os aspetos relacionados com as mesmas.

4 "O que une uma comunidade de cidadãos é a partilha de entendimento possivel - que pode gerar o sentimento de pertença a uma comunidade" - cfr. Alessandra Silveira, Tratado de Lisboa (Lisboa: Quid Juris, 2010), 12. Sucede que o sentido de pertença à União Europeia e o sentimento de confiança nas instituições europeias que os cidadãos de cada Estado-Membro deveriam ter, são restringidos ou, até mesmo, anulados pela circunstância de não terem concreto conhecimento do que se passa em todos os centros de poder e de decisão.

${ }^{5}$ Cfr. Alessandra Silveira, Principios de Direito da União Europeia - Doutrina e Jurisprudência, 2. ${ }^{\text {a }}$ edição, atualizada e ampliada (Lisboa: Quid Juris, 2011), 47.
} 


\section{A boa administração, a transparência e a democracia versus o manto de secretismo do Eurogrupo}

Todo o processo de tomada de decisões que moldem a União Europeia deve ser orientado à luz dos princípios da boa administração e da transparência, em nome de uma efetiva "democracia supranacional europeia". Estão em causa traves mestras que impõem a maior clareza e publicidade em relação ao processo decisório e à decisão propriamente dita, sobretudo, num contexto em que, por força da crise financeira generalizada, as ideias de accoutability e de good governance ganharam um especial relevo. Sucede que a opacidade a que nos temos vindo a reportar surge em negação ao direito à boa administração e em contracorrente perante os princípios da transparência e da democracia. Senão vejamos.

A boa administração constitui um elemento essencial da boa governação e implica, sinteticamente, que a Administração (aqui entendida enquanto instituições, organismos e órgãos da União) respeite os direitos dos cidadãos e que, simultaneamente, providencie serviços públicos eficientes, recorrendo a adequados métodos de gestão. Em concreto, a Carta dos Direitos Fundamentais da União Europeia (CDFUE) concede à ideia de boa administração um especial tratamento, elevando-a a direito fundamental: no art. 41.', da CDFUE, consagra-se o "Direito à boa administração". Trata-se, mais do que uma epígrafe chamativa ${ }^{7}$, de um verdadeiro avanço no que respeita às garantias dos administrados. Através do art. 41. ${ }^{\circ}$, evidencia-se que a União é uma comunidade de Direito e reforça-se a própria cidadania europeia. Neste sentido, considera-se que a CDFUE eleva os direitos por si reconhecidos aos administrados, no plano jurídico europeu, ao estatuto de direitos fundamentais, integrados na categoria de direitos humanos administrativos ${ }^{8}$. Ora, os deveres de transparência e

\footnotetext{
${ }^{6}$ Cfr. Alessandra Silveira, Tratado de Lisboa (Lisboa: Quid Juris, 2010), 12.

${ }^{7}$ Jacob Söderman - antigo Provedor de Justiça Europeu - assinalou, no discurso proferido a 01 de março de 2001 - "The Struggle for Openness in the European Union”, Provedor de Justiça Europeu, acesso em abril 24, 2017, https://www.ombudsman.europa.eu/speeches/en/2001-03-21.htm -, que a aludida epígrafe constitui uma novidade em todo o mundo.

${ }^{8}$ Cfr. Mário Aroso de Almeida, Teoria Geral do Direito Administrativo: temas nucleares (Coimbra: Almedina,
} 
de publicidade surgem, precisamente, como deveres inerentes ao princípio da boa administração, que deve estar subjacente a toda a atuação administrativa. Aliás, a boa administração pressupõe a existência de uma atuação transparente.

Em concretização da ideia de que "a Europa é antes de mais a âncora da nossa democracia' ${ }^{\prime \prime}$, determina o art. 10. ${ }^{\circ}$, do Tratado da União Europeia, que o funcionamento da União se baseia na democracia representativa, tendo todos os cidadãos o direito de participar na vida democrática da União. As decisões são tomadas de forma tão aberta e tão próxima dos cidadãos quanto possível, visto que os cidadãos europeus devem saber o que é que as instituições europeias fazem e porquê. $O$ art. 11. ${ }^{\circ}$ impõe às instituições que criem os meios adequados para que os cidadãos e as associações representativas possam expressar e partilhar publicamente os seus pontos de vista sobre todos os domínios de ação da União e que estabeleçam um diálogo aberto, transparente e regular com as associações representativas e com a sociedade civil. Ainda com relevância, surge o art. 15. ${ }^{\circ}$, do TFUE, nos termos do qual " a fim de promover a boa governação e assegurar a participação da sociedade civil, a atuação das instituições, órgãos e organismos da União pauta-se pelo maior respeito possivel do princípio da abertura". No mesmo sentido, reza o art. 298. ${ }^{\circ}$, do mesmo diploma, que no desempenho das suas atribuições, as instituições, órgãos e organismos da União apoiam-se numa administração europeia aberta, eficaz e independente.

Dito isto, importa, agora, trazer para o plano do Eurogrupo os efeitos que dos aludidos princípios decorrem. Em concreto, cumpre aferir se o Eurogrupo se encontra sujeito ao cumprimento dos princípios da boa administração e da transparência. Isto porque, em conformidade com o que se constatou, o Eurogrupo não detém personalidade jurídica e não se integra no elenco dos órgãos, organismos e instituições da União, ainda que se encontre dotado de uma determinada estrutura institucional, na medida em que dispõe de um Presidente eleito por um determinado período, e ainda que integre o elenco das instituições da União Monetária Europeia,

\footnotetext{
2012), 53 - 54.

${ }^{9}$ Cfr. Ana Gomes, "Europa: crise ou oportunidade?", in 50 anos do Tratado de Roma, Coord. Alessandra Silveira (Lisboa: Quid Juris, 2007), 29.
} 
entre elas se contabilizando ainda o BCE, o SEBC, o Comité Económico e Financeiro e o ECOFIN ${ }^{10}$. Considerando que todos os preceitos supra invocados delimitam o seu âmbito de aplicação aos órgãos, organismos ou instituição da União, em que termos é que os princípios da boa administração e da transparência podem ser aplicados ao Eurogrupo?

Pois bem, na eventualidade de o Protocolo n. ${ }^{\circ} 14$ não vir a sofrer nenhuma alteração, que expressamente imponha ao Eurogrupo uma atuação em conformidade com a boa administração e com a transparência, parece-nos que, salvo melhor opinião, o manto de secretismo terá que ser, ao abrigo dessas mesmas dimensões, levantado. A vinculação aos aludidos princípios surge não por decorrência expressa e direta dos preceitos que os consagram, mas sim pela amplitude com os que mesmos devem ser aplicados. É difícil de conceber que uma entidade da União Europeia (no sentido amplo do termo) não fique adstrita a que a sua concretização seja feita à luz das aludidas traves mestras. Se assim não se entender, este será mais um exemplo em que a Política substitui o Direito, quando, na verdade, a primeira deve estar submetida ao segundo. As “decisões" do Eurogrupo surtem um impacto realmente significativo para União, não podendo, por esse motivo, ficar de fora do âmbito de sujeição dos princípios invocados.

\footnotetext{
10 "O Eurogrupo não pode ser equiparado a uma formação do Conselho nem qualificado de órgão ou organismo da União na acęão do art. 263. ${ }^{\circ}$ TFUE" e "o facto de a Comissão e o BCE participarem nas reuniões do Eurogrupo não altera a natureza das declarações deste último" - cfr. acórdão Mallis e Mali... considerandos 57 e 61. A este respeito, de acordo com o despacho do Tribunal Geral (Primeira Secção) de 16 de outubro de 2014, Konstantinos Mallis e Elli Konstantinou Malli, contra Comissão Europeia e BCE, Processo T327/13, considerandos 42, 43 e 44, embora no art. $1^{\circ}$, do Protocolo do Eurogrupo, esteja prevista a participação da Comissão e do BCE nas reuniões do Eurogrupo, podendo a Comissão também contribuir para a preparação das referidas reuniões, não é possível considerar que o Eurogrupo é controlado pela Comissão ou pelo $\mathrm{BCE}$, nem que age na qualidade de mandatário dessas instituições, pelo que as declarações adotadas pelo Eurogrupo não poderiam ser imputadas à Comissão nem ao BCE. Seguindo a mesma linha de argumentação, no referenciado acórdão Mallis e Mali... considerando 51, o TJUE veio reconhecer que as declarações do Eurogrupo não podem ser objeto de recurso de anulação. A declaração em causa tinha sido destinada a informar o público em geral sobre a existência de um acordo político entre o Eurogrupo e as autoridades cipriotas, tendo entendido o TJUE que a aludida declaração não refletia uma decisão da Comissão Europeia e do Banco Central Europeu, no sentido de criar uma obrigação legal para o Estado-Membro em causa - o Chipre. Sobre o assunto, vide "Engaging EU liability within the European Stability Mechanism framework", Sophie Perez Fernandes, acesso em abril 24, 2017, https://officialblogofunio.com/2016/09/30/editorial-of-october-2016/\#more-1454.
} 
Por outro lado, atendendo, precisamente, à ideia de informalidade, nos termos da qual os procedimentos a adotar no âmbito do Eurogrupo dependem da vontade do próprio, deveria o mesmo, por sua iniciativa, fazer pautar as suas atuações por uma total transparência, salvaguardando, dessa forma, o direito à boa administração. O facto de o Eurogrupo não servir de objeto de Tratados europeus e de resultar do Protocolo n. ${ }^{\circ} 14$ que funciona como um grupo informal, não sendo necessário, por esse motivo, quaisquer regulamentos ou estatutos, não nos parece que sirva para justificar a patente opacidade. Se a liberdade procedimental existe, então que seja aplicada em prol dos princípios que devem enformar todos os procedimentos decisórios ao nível da União.

Ocorreu-nos a hipótese de que a opacidade subjacente ao funcionamento do Eurogrupo se poderá dever, pelo menos em parte, aos termos em que as reuniões têm lugar, ao serem iniciadas e, consequentemente, afetadas ab initio, pelos representantes da Troika (quando participa nas reuniões) ou pelas intervenções dos Ministros representativos dos Estados-Membros com maior influência decisória (desde logo, a Alemanha $\left.{ }^{11}\right)$. Estas intervenções influenciam as dos Ministros presentes. Talvez com o receio de revelar aos cidadãos (ou ao eleitorado) representados pelos respetivos Ministros (e também pela Comissão) a frágil e influenciável posição com que contam no Eurogrupo, opta-se por, simplesmente, nada ou muito pouco trazer a público. Os resultados definidos acabam por ser fruto da vontade dominante da Troika ou da Alemanha e talvez não seja essa a imagem (ainda que correspondente à realidade) que o Eurogrupo pretende transmitir.

Um outro motivo que nos parece poder estar subjacente ao secretismo assentará na circunstância de que no Eurogrupo se encontram essencialmente em discussão questões estritamente técnicas, não compreendidas nem compreensíveis pelos cidadãos europeus. No entanto, quais é que são os assuntos que servem de

\footnotetext{
${ }^{11}$ Em referência à votação realizada em finais de fevereiro de 2012 na Alemanha, relativa ao segundo pacote de ajuda, associado a imposições de austeridade à Grécia, Ulrich Beck relembra o que, nesse dia, ouviu na rádio e que resumiria o estado de espírito e da política da atualidade: "a Alemanha decide, boje, sobre o Ser ou Não-ser da Europa" - cfr. Ulrich Beck, A Europa Alemã - De Maquiavel a "Merkiavel": Estratégias de poder na crise do Euro (Lisboa: Edições 70, 2013), 15 - 16.
} 
objeto de decisão às instâncias europeias que não se reconduzem a matérias jurídicas, financeiras, económicas ou outras dotadas de patente tecnicidade, que só uma parte mais reduzida dos cidadãos europeus são dotados dos conhecimentos necessários para as compreender? Pouquíssimas, ou nenhumas. E ainda que se parta do pressuposto que a maioria dos cidadãos europeus é leiga perante os assuntos em debate na União, devem, mesmo assim, e se assim quiserem, ter a oportunidade de a elas ter acesso, formando a sua própria opinião.

Destarte, nenhum dos motivos apontados justificará a ausência de transparência em torno do Eurogrupo, por ausência de relevo jurídico bastante.

\section{Por um Eurogrupo principiologicamente orientado}

A cultura jurídica da União Europeia encontra como fundamento vários princípios basilares que orientam (ou que, pelo menos deveriam orientar) os atos do poder público europeu.

Considerando que o principal problema subjacente à opacidade aqui objeto de análise se reporta à falta de confiança na própria União Europeia que a mesma é capaz de gerar, parece-nos que aos invocados princípios de boa administração, transparência e democracia devem, ainda, somar-se os "quatro princípios de criação de confiança europeia que constituem o fundamento imprescindivel de uma sociedade europeia"'12. São eles: o princípio da equidade (a construção da União implica sempre a criação não só a consagração de direitos, mas também a criação de obrigações; o princípio do equilíbrio (deve existir equilíbrio na relação entre os Estados grandes e poderosos e os Estados pequenos e menos poderosos, devendo a proteção destes últimos ser prioritária); o princípio da reconciliação (em razão das desigualdades existentes entre os vários países, os parceiros mais fracos devem ser tratados de acordo com uma política de reconciliação, sem atribuição de culpas e menosprezos) e o princípio do impedimento de exploração (devem ser implementados mecanismos que impeçam que os países fortes aproveitem as fraquezas dos outros em benefício próprio). A

\footnotetext{
${ }^{12}$ Esta é uma construção da autoria de Ulrich Beck, A Europa Alemã, 88 - 89.
} 
atuação principiologicamente orientada afigura-se, pois, a nosso ver, uma possível solução - juridicamente fundamentada - para travar o sentimento de descrença perante a União Europeia que começa a ser generalizado.

No que concerne particularmente ao Eurogrupo, parece-nos que é de atribuir especial atenção à forma como se poderá demonstrar, junto dos grupos de cidadãos, que o mesmo funciona eficazmente na prossecução dos objetivos para os quais foi criado, bem administrando e decidindo em prol do bem comum. A nosso ver, e em concreto, as exigências de boa administração e de transparência ditarão, nomeadamente, que: (i) se torne compreensível o processo pelo qual as "decisões" são tomadas (o que poderá justificar um eventual aligeirar da ideia de informalidade, no sentido de o procedimento seguido nas reuniões se encontrar minimamente definido, ainda que possa ser alterado em conformidade com as circunstâncias concretas que se imponham); (ii) as próprias "decisões" sejam devidamente fundamentadas; (iii) as "decisões" sejam publicadas (devendo estar também disponíveis para consulta todos os dados ou elementos que tenham servido de base para a decisão tomada, numa plataforma de acesso gratuito e sem necessidade de registo prévio - ou seja, sem necessidade de introduzir dados de utilizador); (iv) as reuniões sejam ser abertas e públicas (no sentido de poderem ser transmitidas em direto, via televisão ou rádio), garantindo que todos os interessados as possam acompanhar; e que (v) as propostas sobre os assuntos que preocupam e que possam afetar diretamente os cidadãos sejam apresentados previamente à realização das reuniões, para debate público, não no sentido de referendo, mas para que a opinião pública possa ser formada, podendo ser tida, eventualmente, em consideração pelo Eurogrupo. Saliente-se, aliás, que estão disponíveis os recursos técnicos necessários e suficientes para dar concretização a este imperioso desígnio de transparência: a sala onde decorrem as reuniões do Eurogrupo encontra-se munida do material necessário para o efeito, sendo apetrechada com microfones, câmaras e ecrãs, que reproduzem em tempo real todos os discursos realizados.

É que não basta que o Eurogrupo seja eficaz na concretização dos seus objetivos. A eficácia da sua atuação deve, isso sim, vir de mãos dadas com componentes 
estritamente jurídicas, nomeadamente com as da boa administração e da transparência, que funcionam como pré-requisitos da eficiência. E, se assim for, não há que recear a ideia de "deixar a luz entrar".

Em suma, apela-se à transformação de um Eurogrupo informal para um Eurogrupo europeizado, principiologicamente orientado, capaz de contribuir para que a fé na União Europeia não seja destruída por completo. 


\title{
Da consagração do direito ao esquecimento (sobre a responsabilidade dos motores de busca no tratamento de dados pessoais)
}

\begin{abstract}
Andreia Oliveira*
RESUMO: O Acórdão Google consagra-se como um marco importante na matéria de proteção de dados - não só enaltecen o direito ao esquecimento como introduziu o papel dos motores de busca na equação do problema. A questão de saber se a atividade de um motor de busca pode ser considerada como um tratamento de dados pessoais não gerou debate. No entanto, é a questão de saber se um motor de busca pode ser considerado como responsável pelo tratamento que gerou a controvérsia. O presente texto pretende averiguar as situações onde um motor de busca deve ser considerado como responsável pelo tratamento de dados pessoais que, em consequência, o obrigará a respeitar os deveres que um responsável pelo tratamento está adstrito.
\end{abstract}

PALAVRAS-CHAVE: direito ao esquecimento - acórdão Google - Internet-proteção de dados - motores de busca.

ABSTRACT: The Google case is an important milestone in the field of data protection - it not only praised the right to be forgotten, but also introduced the role of search engines in the problem's equation. The question of whether the activity of a search engine could be considered as a processing of personal data did not engender debate. However, it is the question of whether a search engine can be held responsible for the treatment that spawned the controversy. This text aims to ascertain the situations where a search engine should be considered responsible for the processing of personal data which, consequently, will oblige the search engine to respect the duties to which the processing responsible is obliged.

KEYWORDS: the right to be forgotten - Google case - Internet - data protection - search engines.

* Advogada e Mestre em Direito da União Europeia pela Universidade do Minho. 
$\mathrm{Na}$ União Europeia, a proteção das pessoas singulares no que diz respeito ao tratamento dos seus dados pessoais e à livre circulação dos mesmos é regulada pela Diretiva (CE) 95/46 até que as novas regras sobre esta matéria, fruto do nascimento de um Regulamento ${ }^{2}$, sejam aplicáveis em maio de 2018. Um dado pessoal tem a designação de qualquer informação relativa a uma pessoa singular que a possa identificar ou tornar identificável - desde um simples nome até a um endereço de IP. Por sua vez, o processamento - ou tratamento - desses dados diz respeito a qualquer operação ou conjunto de operações realizadas sobre esses dados pessoais com ou sem recurso a meios automatizados - e.g. uma base de dados eletrónica onde um médico armazena toda a informação dos seus pacientes. A existência de um tratamento de dados pessoais pressupõe a existência de um responsável por esse tratamento, cuja identificação reside nas pessoas, ou organismos, que determinam a finalidade e o meio desse tratamento.

No que tange ao direito ao esquecimento torna-se importante referir que este não é, como se possa pensar, um direito novo. No entanto, é um direito cuja tonificação foi alcançada num acórdão emblemático - o acórdão Google ${ }^{3}$ - que contribuiu de forma significativa para que hoje possamos encontrar o direito ao esquecimento engrandecido no novo Regulamento. Em traços gerais, quando os indivíduos não pretendam que os seus dados continuem a ser processados e quando não exista motivos legítimos que justifiquem esse processamento ou retenção, os seus dados deverão ser apagados. Esclareça-se: nunca o direito ao esquecimento pretende apagar o passado ou abalar a liberdade de expressão. $O$ direito ao esquecimento reforça, sim, o direito dos indivíduos em exercerem um controlo sobre os seus dados (especialmente importante num mundo cibernético com inúmeros riscos associados).

Neste percurso, o Acórdão Google trouxe à colação a questão da responsabilidade de um motor de busca. A definição de tratamento de dados não criou quaisquer dúvidas quanto a saber se esta pode dizer respeito à conduta de um motor de

\footnotetext{
1 Diretiva 95/46/CE do Parlamento Europeu e do Conselho, de 24 de outubro de 1995, ECLI:EU:C:2014:317.

${ }^{2}$ Regulamento 2016/679/ UE o Parlamento Europeu e do Conselho, de 27 de abril de 2016.

${ }^{3}$ Acórdão TJUE de 13 de maio de 2014, Google, Processo C-131/12.
} 
busca. Antes, questionou-se se, ao respondermos afirmativamente à questão de englobarmos a conduta de um motor de busca na definição de tratamento de dados pessoais, não deveríamos, obrigatoriamente, responder afirmativamente à questão de considerarmos esses motores de pesquisa como responsáveis pelo tratamento.

No processo em apreço a conclusão não foi unânime: segundo a orientação do Tribunal de Justiça da União Europeia, os motores de busca terão de ser encarados como responsáveis pelo tratamento de dados, mas na opinião do Advogado$\mathrm{Geral}^{4}$, esses motores de busca só funcionam com uma ferramenta de localização de informação - logo, não exercem controlo sobre os dados pessoais incluídos nas página-fonte de um terceiro.

Ora, no entendimento do Advogado-Geral seria importante esclarecer alguns aspetos relacionados com os motores de busca. Vejamos:

a) Os motores de busca, por via de regra, não criam conteúdos novos. Estes apenas indicam o local onde podem ser encontramos conteúdos já existentes.

b) Os resultados obtidos através de uma pesquisa num motor de busca não se baseiam numa pesquisa direta em toda a world wide web. Pelo contrário, baseiam-se em conteúdos que esse motor de pesquisa tratou previamente. Ou seja, isto quer dizer que um motor de pesquisa "recupera conteńdos de sitios web existentes e copia, analisa e indexa esses conteúdos nos seus próprios dispositivos". Sendo certo que esses conteúdos podem conter dados pessoais se algumas das páginas que esse motor analisou incluir tais dados.

c) Os motores de busca disponibilizam conteúdos adicionais para além daqueles contidos no website original - de forma a tornar os resultados mais úteis. Esses conteúdos podem, pelo menos uma parte deles, ser recuperados dos dispositivos do prestador do serviço do motor de busca - o que significa que essa informação é efetivamente detida por esses provedores de serviços.

É, portanto, a posição do Advogado-Geral a de considerar as páginas-fontes como as responsáveis pelo tratamento de dados pessoais e não os motores de

\footnotetext{
${ }^{4}$ Um Advogado-Geral tem a função de apresentar publicamente e de forma imparcial pareceres sobre os processos submetidos ao Tribunal.
} 
busca - os quais só poderiam ser responsáveis em uma situação específica. No seu entendimento, uma vez que essas páginas têm a possibilidade de utilizar códigos de exclusão - e.g. têm a possibilidade de informar os motores de busca para não indexarem ou armazenarem essa página, ou até para não permitir que a mesma seja visualizada nos resultados de pesquisa -, esses websites podem proteger os dados pessoais utilizando esse mecanismo. Logo, na eventualidade de não fazerem uso desse mecanismo, quando o podiam fazer, se uma pessoa publicar informações, hospedeiras de dados pessoais, e proceder ao seu tratamento, ficará como responsável por esse tratamento. E, sendo responsável, terá de respeitar os deveres que lhes são incumbidos - nomeadamente, proceder ao apagamento desses dados.

Neste percurso, foi também equacionada a hipótese de um motor de busca ser considerado como um intermediário de informação. Uma indagação não possível de alcançar sem o deslindamento da Diretiva (CE) 2000/315. De notar que, uma vez retorquido de forma afirmativa à questão de considerar um motor de busca como intermediário, tal significaria a não possível responsabilização do mesmo pelas atividades consideradas ilegais que uma página-fonte possa praticar.

Neste âmbito, um motor de busca só poderá ser considerado como responsável quando se verifique as questões postuladas pela alínea a) ou b) do artigo $14 .^{\circ}$ desse diploma legal quando aplicado a contrário. Concretizando: quando o intermediário tenha "conhecimento efectivo da actividade ou informação ilegal" ou "a partir do momento em que tenha conbecimento da ilicitude" não atue de forma a impossibilitar o acesso a essas informações ${ }^{6}$.

De notar que, a referência a uma possível analogia das atividades de um motor de busca aos serviços enumerados na diretiva em questão, não são consensuais. É o argumento de que os serviços de um motor de busca, ao contrário, dos serviços elencados naquele diploma, não estão sujeitos a pagamento - tornando, assim, a analogia ínvia. No entanto, com o novo Regulamento este argumento deixa de existir em razão do estabelecido no seu artigo 3. ${ }^{\circ}$, n. $^{\circ} 2$, alínea a).

\footnotetext{
${ }^{5}$ Diretiva 2000/31/CE do Parlamento Europeu e do Conselho de 8 de Junho de 2000.

${ }^{6}$ Cf. Giovanni Sartor e Mario Viola de Azevedo Cunha, "The Italian Google-Case: Privacy, Freedom of Speech and Responsibility of Providers for User-Generated Contents", International Journal of Law and Information Technology 18, 4 (2010).
} 
Sem embargo do exposto, mesmo na hipótese de considerarmos um motor de busca como intermediário, a questão de saber se um motor de busca pode ser considerado como um responsável pelo tratamento de dados pessoais continua infecunda. Não fosse essa a razão que levou o Advogado-Geral a admitir que, mesmo atribuindo a responsabilidade aos editores das páginas web, o problema da proteção de dados não fica resolvido. Não só porque podemos estar perante inúmeros editores - o que se tornaria altamente complicado contactar cada um deles -, como também poderíamos deparar com a situação desse editor residir num país terceiro e as páginas web que o mesmo edita não estarem, em consequência, abrangidas pela legislação da União Europeia.

Paralelamente, ainda existe a equação de se considerar um motor de busca como um terceiro - excluindo, assim, a possibilidade de ser considerado como um processador de dados. Não é rara a interpretação de que estaríamos perante a solução mais coerente, advogando-se no sentido de os motores estarem sujeitos a um abuso significativo por parte das entidades reguladoras. A visão do papel dos motores de busca como sendo aquele que torna a Internet tão manejável e útil, parece tornar fácil defender, pelo menos para muitos, de que os órgãos da União deveriam obstar-se em sujeitar esses motores a responsabilidades "incomensuráveis"?.

A conclusão do Tribunal de Justiça estabeleceu-se no sentido de que o direito de privacidade e o direito à proteção de dados têm que prevalecer sobre os interesses económicos existentes na atividade dos motores de busca e do público em geral em receber informação. $\mathrm{Na}$ verdade, o direito à privacidade não pode ser delimitado em função da inconveniência que o mesmo causa às empresas que tiram proveito da recolha e indexação dos dados pessoais dos indivíduos ${ }^{8}$ - salvo se existir, por exemplo, um interesse preponderante do público em geral em receber informação quando o agente em causa (quando o agente dessa informação) desempenha um papel na vida pública.

${ }^{7}$ Cf. Hielke Hijmans, "Right to Have Links Removed - Evidence of Effective Data Protection", Maastricht Journal of European and Comparative Law 21, 3 (2014).

${ }^{8}$ Cf. Joseph Jones, "Control-Alter-Delete: The "Right to be Forgotten" - Google Spain SL, Google Inc v Agencia Española de Protección de Datos", European Intellectual Property Review 36,9 (2014). 
Na nossa humilde opinião, o acórdão Google, mais do altercar a responsabilização dos motores de busca, tem como pano de fundo o alcance de uma solução para a proteção da vida privada, bem como para a efetivação da proteção de dados. Adiantemos: não raras são as vezes que a solução encontrada não é a ideal, tãosomente porque a mesma não existe, existindo apenas a forte necessidade de estabelecer uma solução.

Neste sentido, clarifiquemos: somos da opinião de que, em via de regra e salvo determinadas exceções, um motor de busca não pode ser responsabilizado por danos criados aos seus titulares, quando atua como mero intermediário. No entanto, somos defensores de que a um motor de busca terá de ser suscetível a atribuição de determinadas obrigações quando um dano é causado. A impossibilidade de alcançar uma regulamentação efetiva para defender direitos tão importantes como o direito à proteção de dados pessoais e o direito à vida privada, ambos direitos fundamentais previstos na Carta dos Direitos Fundamentais da União Europeia, apresenta-se como o argumento principal. Consideramos legitimo questionar-se sobre uma possível injustiça na atribuição deste ónus a um motor de pesquisa. Contudo, apesar de legítima, repare-se no seguinte: um motor de busca não atua desprovido de objetivos - estando a maior parte deles ligados a questões económicas. Por outro lado, um motor de busca, como qualquer outro mecanismo que realize uma atividade, seja ela qual for, estará sempre dependente de delimitações - especialmente quando a sua atividade possa pôr em causa direitos tão próprios como os elencados - ou seja, quando essa atividade possa prejudicar outros bens essenciais como os direitos das pessoas. Mais: a "sanção" proferida por mais "transtornos" que possa causar, não é, na nossa opinião, uma sanção altamente lesiva.

Deste modo, somos defensores de que, estando em causa a boa regulamentação das regras da proteção de dados, bem como direitos fundamentais, os motores de busca haverão de ser vistos como responsáveis. Nessa medida, quando o seu modo de funcionamento possa colocar em crise esses direitos fundamentais, os motores de pesquisa devem assumir condutas que obstem esse perigo. Não se equaciona a questão de os motores de busca serem os criadores de danos, mas sim de contribuidores 
para que esses danos se perpetuem e se propaguem. É, portanto, nesse sentido que esses motores devem ser responsabilizados - quando depois de criado um dano, esse assumir características ainda mais nocivas devido aquela atividade que é a atividade de um motor de busca.

Em resumo, os motores de busca não poderão ser considerados como responsáveis pelo tratamento de dados quando o mesmo é previamente tratado por um editor de uma página-fonte. A esses editores seria de atribuir uma responsabilidade primária - editores estes que, em primeiro plano, deveriam de ter a obrigação de balançar os vários direitos em causa, pois são eles que estão em melhor posição para o fazer. Contudo, existem certas situações que os motores de busca terão de ser considerados com responsáveis. Destarte, o nosso entendimento segue-se nos seguintes pontos:

a) Os motores de busca serão responsáveis primários quando não respeitam os códigos de exclusão apresentados pelos editores da página-fonte ou, quando a página-fonte já não estiver disponível, os motores de busca utilizem a funcionalidade "cache", permitindo, assim, o seu acesso.

b) Os motores de busca serão responsáveis secundários (mas entenda-se, igualmente responsáveis) quando detêm o conhecimento de uma ilegalidade e nada fazem para obstar o processamento dos dados sujeitos a essa ilegalidade.

c) Nos restantes casos os motores de busca, ao executarem a sua atividade, não podem apenas beneficiar dos proveitos económicos mas também têm de assumir condutas que não ponham em causa a efetivação da proteção de dados - um direito fundamental existente no território onde esse motor atua e, como tal, terá de respeitar. 



\title{
A previsão na Lei Anticorrupção Brasileira de mecanismos e procedimentos internos de integridade: Compliance Corporativo
}

\author{
Caroline Fockink Ritt*
}

RESUMO: A iniciativa privada possui papel fundamental na prevenção da corrupção e na manutenção de um ambiente corporativo que seja competitivo e que seja pautado por princípios éticos e de integridade. O compliance constitui a obrigação de cumprir regulamentos internos e externos que são impostos às atividades da organização. É adesão da companbia a normas ou procedimentos de determinado setor. Seu objetivo primordial é o combate à corrupção. Estes controles internos representam uma necessidade imperiosa da globalização para combater as fraudes nas organizações, a lavagem de dinheiro, como também o financiamento ao terrorismo. A Lei Anticorrupção brasileira buscou fažer com que as empresas criem mecanismos internos de fiscalização e de incentivo à denúncia de irregularidades. O compliance é necessário, como política privada empresarial, pois tem viés educativo e adotado em todo o mundo que ambicionam empresas e negócios mais éticos.

PALAVRAS-CHAVE: compliance - corrupção - Lei Anticorrupção do Brasil.

ABSTRACT: Private initiative plays a key role in preventing corruption and maintaining a corporate environment that is competitive and is guided by ethical principles and integrity. Compliance is the obligation to comply with internal and external regulations that are imposed on the activities of the organization. It is the company's adherence to industry standards or procedures. Its primary objective is the fight against corruption. These internal controls represent an overriding need for globalization to combat fraud in organizations, money laundering, as well as terrorist financing. The Brazilian Anti-Corruption Law sought to make companies create internal mechanisms for monitoring and encouraging the reporting of irregularities. Compliance is necessary, as a private business policy, because it has educational bias and adopted around the world that ambition for more ethical businesses and businesses.

KEYWORDS: compliance - corruption - Brazilian Anti-Corruption Law.

* Docente de direito penal e doutoranda em Direito na Universidade de Santa Cruz do Sul - UNISC. 


\section{Notas Introdutórias}

O presente estudo aborda a importância do compliance, no ambiente empresarial, para fins de prevenção de práticas corruptivas. Estes controles internos representam uma necessidade imperiosa da globalização para combater as fraudes nas organizações, a lavagem de dinheiro, como também o financiamento ao terrorismo. Ressalta-se que o compliance é necessário, como política privada empresarial, pois tem viés educativo e adotado em todo o mundo que ambicionam empresas e negócios mais éticos.

\section{O Compliance Corporativo: sua importância no ambiente empresarial para prevenção de práticas corruptivas}

Uma empresa considerada ética é aquela que não explora seus fornecedores, nem paga algum tipo de propina para os compradores dos seus produtos. Ela respeita os seus colaboradores e os fornecedores e não comete crimes contra o meio ambiente. Essas condutas, associadas ao lucro, são características de companhias consideradas socialmente responsáveis ${ }^{1}$.

Reconhece-se o papel fundamental da iniciativa privada na prevenção da corrupção e na manutenção de um ambiente corporativo que seja competitivo e que seja pautado por princípios éticos e de integridade. Movimento crescente e de tendência irreversível foi impulsionado, num primeiro momento, pela aplicação rigorosa de legislações anticorrupção ao redor do mundo, particularmente nos Estados Unidos².

A iniciativa privada na prevenção da corrupção traz como consequência um ambiente corporativo mais competitivo e que é baseado em princípios éticos, de integridade. Esse movimento é crescente, e considerado irreversível, se fortaleceu na última década especialmente em decorrência da aplicação rigorosa, nos Estados

\footnotetext{
${ }^{1}$ Cfr. Luis Roberto Antonik, Compliance, ética, responsabilidade social e empresarial: uma visão prática (Rio de Janeiro, RJ: Alta Books, 2016), 46.

${ }^{2}$ Cfr. Bruno Carneiro Maeda. "Programas de Compliance Anticorrupção: importância e elementos essenciais," in Temas de Anticorrup̧ão \& Compliance, ed. Debbio A.D et al. (Rio de Janeiro: Elsevier, 2013), 168.
} 
Unidos do Foreign Corrupt Practices Act ("FCPA") pelo Department of Justice ("DOJ") e pela U.S. Securities \& Exchange Commission (“SEC”). Da mesma forma, pela disseminação de importantes convenções internacionais de combate à corrupção, com destaque para a Convenção sobre o Combate da Corrupção de Funcionários Públicos Estrangeiros em Transações Comerciais Internacionais ("Convenção da OCDE") $)^{3}$.

Os resultados negativos que ocorrem nas empresas decorrem da falta de práticas éticas, desleixo, redução de aparatos de segurança ou excessiva contenção de gastos, como consequência da busca "selvagem" pelo lucro. Então, fazer o certo ou errado sem dar muita atenção para os resultados sociais e ambientais está intimamente ligado à moral da companhia e de seus gerentes. Também está ligada à pressão que os executivos recebem para obter retornos econômico-financeiros a qualquer custo ${ }^{4}$.

O termo compliance é originário da expressão anglo-saxã to comply - e exprime, literalmente, o sentido agir de acordo com uma regra ou comando. Constitui a obrigação de cumprir regulamentos internos e externos que são impostos às atividades da organização ${ }^{5}$.

O compliance é a adesão da companhia a normas ou procedimentos de determinado setor. Seu objetivo primordial é o combate à corrupção. Diferente da ética, que é assumida com espontaneidade, o compliance está relacionado à responsabilidade legal. Ser ético é agir voluntariamente com princípios morais para com a sociedade. Já compliance é cumprir com regras e regulamentos, ou seja, é trabalhar ou agir dentro da lei. O compliance é formado por leis, decretos, resoluções, normas, atos e portarias, ou seja, é todo arcabouço regulatório que é aplicado pelas agências que controlam e regulam o setor no qual a empresa está inserida ${ }^{6}$.

A evolução histórica das atividades de compliance ocorreu pela necessidade do próprio mercado em instituir controles internos, pela necessidade de estar em

\footnotetext{
${ }^{3}$ Cfr. Maeda, "Programas de Compliance Anticorrupção", 168-169.

${ }^{4} \mathrm{Cfr}$. Antonik. Compliance, ética, responsabilidade social e empresarial: uma visão prática, 90.

${ }^{5}$ Sidney Bittencourt. Comentários à Lei Anticorrup̣cão: Lei 12.846/2013 (São Paulo: Editora Revista dos Tribunais, 2014), 84.

${ }^{6} \mathrm{Cfr}$. Antonik. Compliance, ética, responsabilidade social e empresarial: uma visão prática, 46-47.
} 
conformidade. Os controles internos representam uma necessidade imperiosa da globalização para combater as fraudes nas organizações, a lavagem de dinheiro, como também o financiamento ao terrorismo ${ }^{7}$.

\section{Previsão do Compliance na Lei Anticorrupção Brasileira}

Ao mesmo tempo em que se verifica, em nível internacional, um endurecimento do combate à corrupção, observa-se o crescente reconhecimento de programas e procedimentos, que são destinados a prevenir as condutas ilícitas como uma forma de mitigar riscos. O Brasil seguiu o mesmo modelo através da aprovação da Lei Anticorrupção ${ }^{8}$.

A Lei Anticorrup̧̧ão brasileira buscou fazer com que as empresas criem mecanismos internos de fiscalização e de incentivo à denúncia de irregularidades, em seu art. $7^{\circ}$, inciso VIII $^{9}$.

A Lei estabelece, ainda, que seja levada em conta, na aplicação das sanções, a existência de mecanismos e procedimentos internos de integridade, auditoria e incentivo à denúncia de irregularidades e a aplicação efetiva de códigos de ética e de conduta no âmbito da pessoa jurídica ${ }^{10}$.

Estes regulamentos são atos administrativos que não podem inovar a ordem jurídica. A rigor, não podem impor regras de criação de mecanismos ou critérios de avaliação para aplicação de sanções pelo Poder Judiciário, conforme o Princípio da Legalidade (art. 5 , II da CF/88) ${ }^{11}$.

A lei evidencia, dessa forma, uma direção, um caminho para que as empresas mitiguem e atuem prontamente a desvios cometidos pelos seus funcionários, fomentando a escolha desse caminho através de redução de penalidades.

\footnotetext{
${ }^{7}$ Cfr. Célia. Regina Lima Negrão e Juliana de Fátima Pontelo, Compliance, controles internos e riscos: a importância da área de gestão de pessoas (Brasília: Editora Senac - DF, 2014), 23.

${ }^{8}$ Cfr. Maeda. "Programas de Compliance Anticorrupção", 201.

${ }^{9}$ Cfr. Antonio Araldo Ferraz Dal Pozzo, et al., Lei Anticorrupção: apontamentos sobre a Lei no 12.846/2013. (Belo Horizonte: Fórum, 2014), 106.

${ }^{10}$ Cfr. Renato de Oliveira Capanema. "Inovações da Lei no 12.846/2013," in: Lei Anticorrupção empresarial aspectos críticos à Lei 12.846/2013, ed. Nascimento M. D. et al. (Belo Horizonte: Fórum, 2014), 22.

${ }^{11}$ Cfr. Dal Pozzo, et al., Lei Anticorrupção, 106.
} 
A adoção de medidas de integridade, diante da nova realidade trazida pela Lei Anticorrupção não é uma mera opção, mas é uma necessidade. E não somente porque a Lei estabelece possibilidade de atenuação de penalidades, mas também porque, ao diminuir a probabilidade da ocorrência de irregularidades, diante de um cenário de existência de potencial punição, é racional e vantajoso economicamente se precaver ${ }^{12}$.

A Lei Anticorrupção brasileira se alinhou ao padrão internacional de responsabilização individual e empresarial. Na responsabilização individual, as formas delitivas podem ser dolosas e "contra os interesses da empresa", de infração de dever de cuidado, ou "da empresa" ou "a partir da empresa". Uma adequada descrição dos comportamentos nos programas de compliance deve atingir especialmente $\mathrm{O}$ risco permitido, no sentido da definição de práticas negociais de caráter meramente especulativas, inerentes ao mundo dos negócios. Também disciplinará o alcance da aceitação dos presentes, ou a imposição de limites do exercício da confiança ${ }^{13}$.

O Brasil está dando um importante passo para uma nova era de maturidade no seu ambiente de negócios. Com a publicação e a regulamentação da Lei Anticorrupção, o País se alinha às mais rigorosas e avançadas legislações do mundo no combate à corrupção. A Lei afetará profundamente a cultura organizacional de empresas brasileiras e estrangeiras que atuam no País.

O combate à corrupção também depende da iniciativa privada e depende, fundamentalmente, de uma mudança profunda de cultura no ambiente corporativo. Ainda que programas de Compliance possam ser incialmente impulsionados pela concessão de tratamento diferenciado na aplicação de penalidades e sanções, sua adoção e implementação, desde que realizadas de modo efetivo, poderão contribuir significativamente para esse processo de mudança cultural, de um ciclo virtuoso em direção à não tolerância à corrupção ${ }^{14}$.

\footnotetext{
${ }^{12}$ Cfr. Capanema. "Inovações da Lei no 12.846/2013”, 25.

${ }^{13}$ Cfr. Renato de Mello Jorge Silveira and Eduardo Saad-Diniz, Compliance, direito penal e lei anticorrupção (São Paulo: Saraiva, 2015), 337.

${ }^{14}$ Cfr. Maeda, "Programas de Compliance Anticorrupção", 201.
} 


\section{Notas conclusivas}

A corrupção acontece não somente na esfera pública, mas práticas corruptivas no ambiente privado são também muito nefastas. Quando se aborda o compliance, que tem viés preventivo, estamos nos referindo aos sistemas de controles internos que permitam esclarecer e proporcionar maior segurança àqueles que se relacionam com as empresas.

O compliance é necessário, como política privada empresarial, pois tem viés educativo e adotado em todo o mundo que ambicionam empresas e negócios mais éticos. O combate à corrupção também depende da iniciativa privada e depende, fundamentalmente, de uma mudança profunda de cultura no ambiente corporativo.

Ainda que programas de Compliance possam ser incialmente impulsionados pela concessão de tratamento diferenciado na aplicação de penalidades e sanções, sua adoção e implementação, desde que realizadas de modo efetivo, poderão contribuir significativamente para esse processo de mudança cultural, de um ciclo virtuoso em direção à não tolerância à corrupção. 


\section{Os contratos públicos como instrumento de concretização de políticas sociais num novo contexto europeu}

\section{Cláudia Viana*}

RESUMO: A Reforma das Diretivas relativas aos contratos públicos, ocorrida em 2014, visa incentivar a utilização dos contratos públicos como ferramentas ou alavancas suscetiveis de promover outras políticas públicas, em sintonia com a Estratégia Europa 2020. O presente estudo debruça-se sobre este novo paradigma, vulgarmente designado como contrataşão pública estratégica, e, em especial, sobre a utilização dos contratos públicos como instrumentos da prossecução de políticas sociais.

PALAVRAS-CHAVE: contratos públicos - directivas de 2014 - estratégia Europa 2020 - contratação pública socialmente comprometida.

ABSTRACT: The 2014 reform of the public procurement directives seeks to boost the use of public procurement as a tool to promote other public polices, in accordance with the Europe 2020 strategy. The present study examines this new paradigm, usually known as strategic public procurement, giving special attention to the utilization of public procurement as an instrument in the prosecution of social policies.

KEYWORDS: public procurement - 2014 directives - Europe 2020 strategy - socially aware public procurement.

\footnotetext{
* Professora da Escola de Direito da Universidade do Minho. Coordenadora Nacional da REDICOP Rede Iberoamericana de Contratación Pública. Membro Doutorado do Centro de Estudos em Direito da União Europeia - CEDU.
} 


\section{A evolução do direito europeu dos contratos públicos in a nutshell}

Logo após o arranque do projeto comunitário e europeu, e não obstante o silêncio dos Tratados, as autoridades comunitárias e europeias reconheceram que: i) a integração dos contratos públicos no então mercado comum, agora mercado interno, decorre da igualdade e das liberdades de circulação reconhecidas aos operadores económicos dos Estados-Membros; ii) as transações económicas subjacentes aos contratos públicos têm um forte impacto no mercado comum e interno ${ }^{1}$; iii) dada a insuficiência da mera consagração dos princípios e regras fundamentais do mercado, torna-se necessária a implementação de uma disciplina específica, que estabeleça medidas de coordenação dos procedimentos pré-contratuais realizados pelas entidades adjudicantes dos diversos Estados-Membros; iv) e, por último, importa garantir a efetividade dessa regulação específica, através de medidas, também elas próprias e específicas, de garantia e tutela dos direitos dos operadores económicos eventualmente lesados.

Tal como anunciado nos Programas Gerais de 1961 e na declaração anexa do Conselho ${ }^{2}$ - que revela a “ligação umbilical” entre os contratos públicos e o mercado - , o legislador comunitário e europeu foi concretizando, step by step, e em feed-back com o Tribunal de Justiça (TJ), todo um quadro normativo orientado para a integração dos contratos públicos num mercado que visa promover e garantir o acesso e a competição, com base no mérito, entre os operadores económicos, neles se incluindo os interessados na celebração de um contrato público.

Atualmente ${ }^{3}$, a disciplina jurídica específica integra: a Diretiva 2014/23/UE, do

\footnotetext{
${ }^{1}$ Atualmente, cerca de 18\% do PIB da União Europeia.

${ }^{2}$ Declaração aprovada na 563. ${ }^{\circ}$ sessão do Conselho da CEE, Bruxelas, dias 23 a 25 de outubro de 1961.

${ }^{3}$ Numa breve sinopse histórica do direito derivado comunitário e europeu dos contratos públicos, podemos destacar várias fases normativas, a saber: i) as diretivas de "liberalização" e de "coordenação" - ou, dito de outro modo, diretivas de integração negativa e de integração positiva; ii) as diretivas de "consolidação", incluindo a aprovação das "diretivas-recursos"; iii) as diretivas de "codificação" de 2004; e, por último, volvidos dez anos, iv) a aprovação das diretivas de 2014, habitualmente designadas "diretivas de quarta geração".

Até à Reforma de 2014, as diretivas substantivas regulavam, de forma muito detalhada, aspetos diversos, ainda que quase exclusivamente relativos à fase de formação do contrato, privilegiando a efetiva abertura
} 
Parlamento Europeu e do Conselho, de 26 de fevereiro de 2014, relativa à adjudicação de contratos de concessão; a Diretiva 2014/24/UE, do Parlamento Europeu e do Conselho, de 26 de fevereiro de 2014, relativa aos contratos públicos; e a Diretiva 2014/25/UE, do Parlamento Europeu e do Conselho, de 26 de fevereiro de 2014, relativa aos contratos públicos celebrados pelas entidades que operam nos setores da água, energia, transportes e serviços postais, todas publicadas no JO L, n. ${ }^{\circ}$ 94, de 28 de março de 2014.

$\mathrm{Na}$ medida em que, e contrariamente ao que sucede no contexto empresarial, a motivação das decisões do Estado e das restantes entidades públicas raramente assenta na estrita racionalidade económica, visa-se garantir que os contratos que estes pretendem celebrar com os operadores económicos, enquanto transações económicas com impacto no mercado interno, respeitem as regras em que este

dos contratos públicos ao mercado, incluindo em especial: i) a proibição de discriminações diretas e indiretas, abrangendo as que decorrem de especificações, requisitos e cláusulas insertas nos documentos do procedimento; ii) a garantia de condições de igualdade de oportunidades e de tratamento entre todos os concorrentes, em condições de transparência, designadamente através da publicidade e da prévia fixação (autovinculação) e estabilização ("congelamento") das "regras do jogo"; e, iii) a objetividade da decisão de adjudicação, vinculada a critérios previamente definidos e divulgados. Destacam-se, entre outros: a definição do âmbito subjetivo e objetivo de aplicação; a proibição de fracionamentos indevidos; a definição técnica do objeto do contrato, através das denominadas especificações técnicas; os tipos de procedimentos pré-contratuais; critérios de seleção qualitativa -"situação pessoal" e capacidades técnica e financeira - dos concorrentes ou candidatos; critérios de adjudicação e regras de publicidade. Há, de todo o modo, que sublinhar que a "diretiva-setores especiais" admitia uma maior flexibilidade das regras relativas aos procedimentos pré-contratuais, comparativamente com o regime traçado nas "diretivas-setores gerais", o que se mantém, enquanto caraterística (originariamente) diferenciadora dos dois regimes.

Por último, impõe-se uma, ainda que sucinta, referência às "diretivas-recursos" - Diretivas 89/665 e 92/13, alteradas pela Diretiva 2007/66 - que contemplam os meios de tutela a utilizar pelos agentes económicos que se considerem lesados por decisões ilegais das entidades adjudicantes, como sejam o processo urgente de impugnação de decisões; adoção de medidas cautelares e de medidas urgentes; concessão de indemnização, incluindo ainda regras relativas à invalidade dos contratos.

A finalizar, registe-se ainda a aprovação da primeira diretiva sobre os contratos públicos celebrados no setor da defesa - a Diretiva 2009/81/CE, do Parlamento Europeu e do Conselho, de 13 de Julho de 2009, relativa à "coordenação dos processos de adjudicação de determinados contratos de empreitada de obras públicas, de fornecimento de bens móveis e de aquisição de serviços, celebrados por entidades adjudicantes nos domínios da defesa e da segurança" - que, não obstante as suas especificidades, representa mais um "passo" na evolução expansiva do direito europeu dos contratos públicos, incidindo numa área especialmente "sensível”, com inevitáveis e relevantes consequências nos regimes jurídicos nacionais. 
assenta, assegurando-se, assim, uma competição em condições de igualdade, não discriminação em razão da nacionalidade e sem obstáculos ou entraves, diretos ou indiretos, às liberdades de circulação.

E, por isso, esta disciplina jurídica dirige-se aos Estados, bem como às entidades públicas (e, para esse efeito, equiparadas ${ }^{4}$ ) que, não atuando em ambiente concorrencial, têm de recorrer ao mercado seja para a prossecução das suas atividades seja para a satisfação das suas necessidades de funcionamento, celebrando, para esse efeito, contratos com agentes económicos, a quem também se garante a tutela dos seus direitos e interesses ${ }^{5}$.

E se é certo que a evolução do direito europeu dos contratos públicos foi sendo concretizada através de diversas diretivas, sucessivamente aperfeiçoadas, aplicáveis quer aos procedimentos pré-contratuais quer aos direitos e garantias dos operadores económicos interessados na obtenção de um contrato público, há que sublinhar que esta construção jurídica foi ainda, ao longo destas décadas, objeto de uma interpretação teleológica e funcional do TJ, que contribuiu inequivocamente para a sua consolidação, reforço e mesmo expansão, em ordem a garantir a efetividade do direito dos contratos públicos enquanto instrumento de concretização do mercado único e de prossecução do projeto europeu, posteriomente "alinhado", como veremos, com a promoção de políticas sociais (e ambientais) através dos contratos públicos.

Trata-se, por isso, hoje, de um corpus iuris constituído por direito originário - Tratados e Jurisprudência - e direito derivado, integrado num contexto jurídico global, em especial o resultante da Organização Mundial de Comércio (OMC), na sequência dos compromissos internacionais assumidos pela União Europeia no

\footnotetext{
${ }^{4}$ Reportamo-nos aos “organismos de direito público" (artigo 2. ${ }^{\circ}$, n. $\left.{ }^{\circ} 1,4\right)$ da Diretiva 2014/24). Há ainda que ter em conta as entidades privadas submetidas ao regime de contratação pública, em virtude da natureza do financiamento obtido (artigo 13. ${ }^{\circ}$ da Diretiva 2014/24). Apenas por razões de simplificação do texto, doravante apenas indicaremos os artigos da Diretiva 2014/24, sem prejuízo das disposições pertinentes contidas nas Diretivas 2014/23 e 2014/25.

${ }^{5}$ Por via da imposição de uma disciplina processual específica, concretizada nas vulgarmente designadas "diretivas-recursos", mencionadas na nota 3.
} 
âmbito do Acordo sobre os Contratos Públicos (ACP) $)^{6}$. É ainda de notar que o direito europeu dos contratos públicos integra princípios e normas jurídicas substantivos, procedimentais e processuais, comummente reconhecidos por organizações internacionais, como os vertidos na "Lei-Modelo" das Nações Unidas", entre outras.

\section{A Reforma de 2014: uma contratação pública socialmente comprometida}

A Reforma de 2014, concretizada nas já referidas Diretivas 23, 24 e 25, visa alcançar dois objetivos principais: por um lado, e numa linha de continuidade, pretende-se garantir que a celebração dos contratos públicos respeita os princípios fundamentais dos Tratados, de modo a prosseguir a efetiva abertura do mercado à concorrência; e, por outro lado, de forma inovadora, pretende-se utilizar os contratos públicos como ferramentas ou "alavancas" de promoção de políticas públicas sociais, ambientais e de inovação, de molde a contribuir para o crescimento inteligente, sustentável e inclusivo do mercado, tal como assumido na Estratégia Europa 2020.

Ainda que de modo necessariamente sucinto, afigura-se-nos importante realçar que a Reforma de 2014 privilegia: i) o incremento do acesso aos contratos públicos, designadamente por via da obrigatoriedade ${ }^{9}$ do e-procurement integral ${ }^{10}$ e da simplificação das formalidades, de que se destaca a utilização do

\footnotetext{
${ }^{6}$ Cfr. ACP (2012) publicado no JO L 68, de 07.03.2014.

7 A "Lei-Modelo" (1994) da UNCITRAL - United Nations Commission on International Trade Law tem contribuído significativamente para a harmonização internacional dos regimes nacionais de contratação pública, através da adoção de um padrão normativo flexível e abrangente, estimando-se que já tenha sido acolhida em mais de 30 países, sobretudo países em vias de desenvolvimento. Com a revisão de 2011, pretende refletir as melhores práticas internacionais e representar a interseção do carrefour jurídico mundial em matéria de contratação pública, alargando e reforçando a sua influência num maior número de ordenamentos jurídicos nacionais.

${ }^{8}$ Comunicação da Comissão ao Parlamento Europeu, ao Conselho, ao Comité Económico e Social Europeu e ao Comité das Regiões - Acto para o Mercado Único - dože alavancas para estimular o crescimento e reforçar a confiança mútua "Juntos para um novo crescimento", COM (2011) 206 final, Bruxelas.

${ }^{9}$ Sem prejuízo da fixação de um prazo longo para a transposição - cfr. artigo 90. ${ }^{\circ}$, n. 2 da Diretiva 2014/24.

${ }^{10}$ Comunicação da Comissão ao Parlamento Europeu, ao Conselho, ao Comité Económico e Social Europeu e ao Comité das Regiōes - Acto para o Mercado Único II - "Juntos para um novo crescimento", COM (2012) 573 final, Bruxelas.
} 
"Documento Europeu Único da Contratação Pública" "11; ii) a flexibilização de procedimentos e a explicitação das condições da sua utilização; iii) a utilização de técnicas promotoras de maior racionalização e eficiência nas despesas públicas subjacentes aos contratos públicos, como a agregação ou a centralização ou ainda a adjudicação conjunta, sem prejuízo de se reafirmar e explicitar a opção por outras formas de colaboração interadministrativa, decorrentes do princípio da liberdade de auto-organização administrativa ${ }^{12}$; iv) a promoção da participação das PME, através de um elenco de medidas específicas - como a simplificação dos encargos administrativos, através da utilização do "Documento Europeu Único da Contratação Pública" e a participação em procedimentos précontratuais, com apresentação de proposta relativa a apenas um ou vários lotes do objeto do contrato - e/ou tendencialmente favorecedoras do seu acesso aos contratos públicos; v) a promoção da inovação, através da previsão de um novo procedimento designado "parceria para a inovação", bem como do incentivo à utilização de propostas variantes, potenciando a investigação aplicada e o Knowhow do mercado; vi) a utilização dos contratos públicos como instrumentos de concretização de outras políticas públicas, designadamente no âmbito ambiental e social; e, vii) o reforço da integridade nos contratos públicos.

Na Reforma de 2014, destaca-se ainda a aprovação da Diretiva 2014/23, relativa aos contratos de concessão, que representa um marco relevante da evolução do direito europeu dos contratos públicos, ao estabelecer, pela primeira vez, um regime jurídico único e específico para todos os contratos de concessão, quer de obras quer de serviços públicos - que, como se sabe, representam cerca de $60 \%$ das parcerias

Cfr. ainda a Diretiva 2014/55, do Parlamento Europeu e do Conselho, de 16 de abril de 2014, relativa à faturação eletrónica nos contratos públicos.

${ }^{11}$ Aprovado pelo Regulamento de Execução (UE) da Comissão, de 5 de janeiro de 2016, que estabelece o formulário-tipo do "Documento Europeu Único de Contratação Pública", na sequência do estabelecido no art. 59. ${ }^{\circ}$, n. $^{\circ} 2$ da Diretiva 2014/24 e no art. 80. ${ }^{\circ}$, n. 3 da Diretiva 2014/25.

${ }^{12}$ Cfr. artigo $12{ }^{\circ}$ da Diretiva 2014/24, que, também aqui, procede à positivação da jurisprudência do TJ. Vale a pena recordar que no que respeita à vulgarmente designada contratação in house essa positivação já tinha sido equacionada no âmbito do processo legislativo relativo às Diretivas de 2004, mas, lamentavelmente, não se conretizou. Para mais desenvolvimentos, ver o nosso Os princípios comunitários e contratação pública (Coimbra Editora, 2007), 474 e ss. 
ou colaborações público-privadas -, positivando uma jurisprudência consistente e reiterada do TJ, iniciada com o acórdão Telaustria, de dezembro de $2000^{13}$.

Mas a grande novidade da Reforma de 2014 consiste, em nosso entender, na adoção de uma visão estratégica e sustentável ou, como preferimos, socialmente comprometida da contratação pública, agora perspetivada como instrumento de políticas públicas diversas e setoriais, em detrimento da exclusividade da racionalidade económico-financeira que sempre dominou a evolução do direito europeu dos contratos públicos, ainda que (já) ligeiramente mitigada nas Diretivas de 2004.

Dito de outro modo, não obstante a mutabilidade dos concretos objetivos que se associam, como acima referimos, a cada uma das "geracõos" de diretivas, certo é que todos eles representam (apenas) momentos de um percurso (sempre) orientado para a abertura dos contratos públicos à concorrência e competição dos operadores económicos no espaço europeu, decorrente de uma conceção (quase) exclusivamente económico-financeira, quer na perspetiva do setor privado quer na perspetiva do setor público.

Sem prejuízo, também nos últimos anos, e como adiante veremos, foram sendo visíveis preocupações de outra índole, designadamente a possibilidade de integração de políticas de natureza social e ambiental, bem como a promoção do acesso das PME aos contratos públicos, que justificaram algumas referências nas Diretivas de 2004, bem como nas diversas iniciativas de soft law, revelando também aqui, mais uma vez, um "fenómeno de feed-back, [em que] jurisprudência e norma se retroalimentam"14.

Agora expressamente enquadrada na Estratégia Europa 2020, visa-se um reforço do caráter instrumental dos contratos públicos, que, por isso, está - ou deve estar - ao serviço dos diversos interesses e fins de interesse público que justificam e norteiam a construção do projeto europeu, sem prejuízo da manutenção, reiterada, da prossecução

\footnotetext{
${ }_{13}$ Coloca-se, assim, um ponto final numa longa controvérsia assente em construções jurídicas (que se vieram a revelar) incompatíveis com a conceção europeia dos contratos públicos enquanto transações económicas com impacto no mercado, e que consubstancia (mais) um relevante alargamento do âmbito objetivo do direito dos contratos públicos.

${ }^{14}$ Assim se refere Melán Gil, no "Prólogo", com que nos honrou aquando da publicação da nossa tese de doutoramento Os princípios comunitários e contratação pública (Coimbra: Coimbra Editora, 2007), 7 e ss.
} 
dos objetivos de uma economia de mercado e da racionalidade da gestão dos dinheiros públicos, também eles de reconhecido interesse público - europeu, e não meramente nacional -, tal como decorre do nosso compromisso com a União Europeia ${ }^{15}$.

Importa, assim, reenquadrar a contratação pública e reforçar a sua utilização em ordem à promoção de políticas públicas, que não apenas de índole económica e financeira, no novo contexto em que vivemos. Um novo contexto, porque o mercado mudou e porque a União Europeia e o mundo também mudaram, o que obriga e exige a adaptabilidade dos objetivos associados aos contratos públicos, enquanto ferramentas orientadas num e para um compromisso com a sociedade, que reclama, (já) não um qualquer crescimento, mas um crescimento sustentável, inteligente e inclusivo numa Europa que, apesar da crise, et pour cause, se pretende concretizar e salvaguardar.

Assim, entendemos que a concretização da Reforma de 2014 depende, em grande medida - e para além de um acervo relevante de fatores exógenos, que aqui não cumpre explicitar -, de uma atuação dos poderes públicos que (já) não se basta com o apelo tout court ao mercado, mas exige responsabilidade e compromisso com as exigências e os desafios que a sociedade enfrenta.

Ora, é nesta perspetiva que, a nosso ver, se deve reenquadrar e compreender a promoção de políticas sociais através dos contratos públicos, enquanto pressuposto indispensável à concretização de uma contratação pública responsável e comprometida com a sociedade.

Nas próximas linhas, procurar-se-á dar conta da relevância deste novo paradigma da contratação pública, focando as novidades relativas à promoção de políticas sociais insertas na Reforma de 2014.

\footnotetext{
${ }^{15}$ Como salienta a Comissão Europeia, “as entidades públicas gastam cerca de $18 \%$ do PIB da UE em bens, serviços e obras. As legislações europeias e nacionais abriram os contratos públicos à concorrência leal, o que teve por consequência facultar aos cidadãos uma melhor qualidade ao melhor preço. Mas, [...] os contratos públicos oferecem oportunidades de aumentar a procura de bens, serviços e obras respeitadores do ambiente, socialmente responsáveis e inovadores. Por outras palavras, os contratos públicos podem servir de ferramenta para fomentar o desenvolvimento de um mercado interno mais ecológico, social e inovador". Acresce que [...] o acesso ao mercado deve tornar-se ainda mais fácil, em particular para as PME in Comunicação da Comissão ao Parlamento Europeu, ao Conselho, ao Comité Económico e Social Europeu e ao Comité das Regiões - Acto para o Mercado Único - doze alavancas para estimular o crescimento e reforçar a confiança mútua..., cit., p.20.
} 


\section{Em especial: a promoção de políticas sociais através dos contratos públicos}

Como acima dissemos, a marca identitária do direito europeu dos contratos públicos pode caracterizar-se como o resultado de um processso step by step e de feed-back entre a jurisprudência e a norma, fenómeno esse que também se evidencia na promoção de objetivos sociais (e ambientais) através dos contratos públicos. Cumpre, aliás, notar que a evolução registada na utilização dos contratos públicos para a promoção de políticas sociais não pode ser dissociada da relativa às políticas ambientais, o que ocorre, em grande medida, através da jurisprudência ${ }^{16}$.

\subsection{Antecedentes jurisprudenciais e normativos}

No acórdão Beentjes, de 20 de setembro de $1988^{17}$, o Tribunal de Justiça admitiu, pela primeira vez, a possibilidade de integração de cláusulas de índole social nos contratos públicos.

Admitindo que "a exigência de empregar desempregados de longa duração poderia violar o princípio da não discriminação em razãa da nacionalidade consagrado no $n .^{\circ} 2$ do artigo $7 .^{\circ}$ do Tratado no caso de se verificar que essa condição apenas poderia ser preenchida pelos proponentes

\footnotetext{
${ }^{16}$ Por isso mesmo, teremos aqui de chamar à colação alguma jurisprudência emblemática relativa à integração de políticas ambientais nos contratos públicos.

${ }^{17}$ Acórdão TJUE de 20 de setembro de 1988, Beentjes, Processo 31/87, EU:C:1988:422. Estava em causa um contrato de empreitada de obras públicas, regido pela Diretiva 71/35. Como refere o Tribunal, no que respeita aos critérios de adjudicação das obras, o n. ${ }^{\circ} 1$ do artigo $29 .^{\circ}$ prevê que as entidades adjudicantes utilizem ou o critério do "preço mais baixo" ou o critério da "proposta economicamente mais vantajosa", que implica a consideração de diversos subcritérios, variáveis consoante o objeto do contrato ( no caso, um contrato de empreitada de obras públicas), como por exemplo: o preço, o prazo de execução, o custo de utilização, a rendibilidade, o valor técnico. "Se a segunda alternativa deixa às entidades adjudicantes a escolha dos critérios de adjudicação das obras que entendam fixar, essa escolha só pode fazer-se entre critérios para identificação da proposta economicamente mais vantajosa. De facto, é apenas a título de excepção que o n. ${ }^{\circ} 4$ do mesmo artigo admite que a adjudicação possa ser baseada em critérios de natureza diversa "no âmbito de uma regulamentação que vise beneficiar certos concorrentes de uma preferência a título de auxílio, desde que a regulamentação invocada seja compatível com o Tratado e, designadamente, com os artigos $92 .^{\circ}$ e seguintes”““.
} 
nacionais ou que seria mais dificilmente preenchida por proponentes de outros Estados-membros" - o que "cabe ao juiz nacional verificar, tendo em consideração as circunstâncias do caso concreto, se a exigência dessa condição tem ou não uma incidência discriminatória directa ou indirecta" -, o Tribunal concluiu que "a condição de emprego dos desempregados de longa duração é compativel com a directiva se não tiver incidência discriminatória directa ou indirecta em relação a proponentes de outros Estados-membros da Comunidade. Tal condição particular suplementar deve ser obrigatoriamente mencionada no anúncio do concurso".

Isto é, o Tribunal admitiu que a entidade adjudicante podia impôr condições de natureza social, enquanto "condição suplementar", desde que não discriminatória e previamente publicitada, ainda que fique a dúvida se esta condição se qualifica como subcritério de adjudicação ou condição de execução do contrato ${ }^{18}$.

No acórdão Comissão/França, de 26 de setembro de $2000^{19}$, o Tribunal começou por recordar que, "nos termos do $n .{ }^{\circ} 1$ do artigo $30{ }^{\circ}$ da Directiva 93/37, os critérios que a entidade adjudicante pode tomar por base para a adjudicação de contratos são unicamente o preço mais baixo ou, quando a adjudicação se fizer à proposta economicamente mais vantajosa, vários critérios que variam consoante o contrato em questão: por exemplo, o preço, o prazo de execução, o custo de utilização, a rentabilidade e o valor técnico".

Contudo, o Tribunal admitiu que aquela disposição " não exclui contudo a possibilidade de as entidades adjudicantes utilizarem como critério uma condição relacionada com a luta contra o desemprego se tal condição respeitar todos os princípios fundamentais do direito comunitário e designadamente o princípio da não discriminação, tal como resulta das disposições do Tratado em matéria de direito de estabelecimento e de livre prestação de serviços (v., neste sentido, referido acórdão Beentjes). Além disso, mesmo que tal critério não seja enquanto tal incompativel com a Directiva 93/37, a sua aplicação deve ter lugar no respeito de todas as normas processuais da directiva, e nomeadamente das regras de publicidade dela constantes (v., neste sentido, relativamente à Directiva 71/305, o acórdão Beentjes, já referido). Daqui decorre que um critério de adjudicação relacionado

\footnotetext{
${ }^{18}$ Neste sentido, D.C. Dragos e B. Neamtu, "Sustainable public procurement in the EU: experiences and prospects" in Modernising Public Procurement: the new directive, eds. Francois Lichère, Roberto Caranta e Steen Treumer (European Procurement Law Series, DJOF Publishing, 2014), 301 e ss.

${ }^{19}$ Acórdão TJUE de 26 de setembro de 2000, Comissão vs. França, Processo C-225/98, EU:C:2000:494, relativo a um contrato de empreitada de obras públicas regido pela Diretiva 93/37.
} 
com a luta contra o desemprego deve ser expressamente mencionado no anúncio de concurso por forma que os empreiteiros estejam em condiçôes de ter conhecimento da existência de tal condição".

Mas o Tribunal vai mais longe e esclarece que "no que se refere ao argumento apresentado pela Comissão de que o acórdão Beentjes, já referido, dizía respeito a uma condição de execução do contrato e não a um critério de adjudicação da empreitada, basta declarar que, como claramente decorre do [...] referido acórdão Beentjes, a condição de emprego de desempregados de longa duração, que estava em causa nesse processo, servia de fundamento para a exclusão de um proponente, não podendo, assim, deixar de constituir um critério de adjudicação da empreitada, relacionado com a luta contra o desemprego e que deve ser expressamente mencionado", pelo que conclui que "não tendo a Comissão argumentado que o critério relacionado com a luta contra o desemprego não respeita os princípios fundamentais do direito comunitário, designadamente o princípio da não discriminação, nem que não foi publicado no anúncio de concurso", deve ser aceite o critério de adjudicação adicional relacionado com a luta contra o desemprego.

Esta jurisprudência foi objeto da atenção da Comissão Europeia, que, em 15 de outubro de 2001, aprova uma Comunicação interpretativa sobre o direito comunitário aplicável aos contratos públicos e as possibilidades de integrar aspetos sociais nesse contexto ${ }^{20}$. No essencial, a Comissão refere que as possibilidades de integração de aspetos sociais na contratação pública ocorrem privilegiadamente no momento da escolha do objeto do contrato e da definição das respetivas especificações técnicas (momento prévio, que antecede o lançamento do procedimento pré-contratual) e em sede de execução do contrato, considerando que se trata de uma fase não regulada ou escassamente regulada pelas diretivas comunitárias, mas sempre desde que sejam respeitados os princípios fundamentais e as liberdades de circulação ${ }^{21}$.

\footnotetext{
${ }^{20} \mathrm{COM}$ (2001) 566 final, de 15.10.2001. Esta Comunicação é antecedida da aprovação, no mesmo ano, pela Comissão da Comunicação interpretativa sobre o direito comunitário aplicável aos contratos públicos e as possibilidades de integrar considerações ambientais nos contratos públicos, COM (2001) 274 final, de 04.07.2001. Esta última Comunicação foi seguida de diversas outras sobre o ambiente, ainda que de âmbito mais extenso, mas que frequentemente incluíam referências aos contratos públicos. Para mais desenvolvimentos, ver o nosso Os princípios comunitários e contratação, 54 e ss.

${ }^{21}$ Note-se que, nas propostas de diretivas, apresentadas pela Comissão no ano de 2000, não constavam quaisquer regras sobre esta matéria. Isto, não obstante o Parlamento Europeu, na Resolução sobre a Comunicação da Comissão relativa aos contratos públicos, de 9 de setembro de 1999 (JO C 150, de 28.05.1999), ter defendido a inclusão "em futuras directivas relativas a contratos públicos, de disposições que obriguem
} 
Mas o passo decisivo decorre da interpretação perfilhada pelo Tribunal de Justiça que, no acórdão Concordia, de 17 de setembro de 200222, adota uma interpretação mais ampla e deixa claro que o critério da "proposta economicamente mais vantajosa" 23 previsto no art. $36 .^{\circ}$ da Diretiva 92/50 (com redação substancialmente idêntica nas restantes diretivas, e em especial na Diretiva 93/38), permite a utilização de vários subcritérios que não são enumerados de modo taxativo no preceito e, em especial, e contrariamente ao defendido pela Comissão, não têm de ser de natureza puramente económica, desde que fique salvaguardada a sua ligação ao objeto do contrato e o respeito pelos princípios fundamentais e liberdades de circulação.

Assim, para o Tribunal, na utilização do "critério da proposta economicamente mas vantajosa", é possível "tomar em consideraşão critérios ecológicos, como o nivel de emissões de óxido de azoto on o nivel sonoro dos autocarros, desde que esses critérios estejam relacionados com o objecto do contrato, não confiram à referida entidade adjudicante uma liberdade de escolha incondicional, estejam expressamente mencionados no caderno de encargos ou no anúncio de concurso e respeitem os princípios fundamentais do direito comunitário, designadamente o princípio da não discriminação" ${ }^{24}$.

O passo seguinte consistiu na positivação desta jurisprudência nas Diretivas de $2004^{25}$, que é assumida pelo legislador logo no $1 .^{\circ}$ Considerando ${ }^{26}$, ao dispor que "a presente directiva baseia-se na jurisprudência do Tribunal de Justiça, nomeadamente naquela

ao cumprimento de cláusulas sociais nos contratos, a fim de permitir aos contratantes desenvolver uma acção positiva ao nível do emprego e da promoção dos objectivos sociais".

22 Acórdão TJUE de 17 de setembro de 2002, Concordia, Processo C-513/99, EU:C:2002:495. Neste leading case, e de forma sucinta, estava em causa a celebração de um contrato de serviços de gestão da rede de autocarros urbanos da cidade de Helsínquia.

${ }^{23}$ As Diretivas 92/50,93/36,93/37 e 93/38, à data aplicáveis, estabeleciam que as entidades adjudicantes podiam optar entre um de dois critérios: o critério do "preço mais baixo" ou o critério da "proposta economicamente mais vantajosa", integrado por ais do que um subcritério, pelo menos.

${ }^{24}$ Também com interesse, cfr. acórdão TJUE de 18 de outubro de 2001, SLAC, Processo 19/00, EU:C:2001:553 e acórdão TJUE de 4 de dezembro de 2003, EVN AG, Processo C-448/01, EU:C:2003:651.

${ }^{25}$ Diretiva 2004/17/CE, do Parlamento Europeu e do Conselho, relativa aos contratos públicos nos setores da água, energia, transportes e serviços postais, e Diretiva 2004/18/CE, do Parlamento Europeu e do Conselho, relativa aos contratos públicos de empreitada de obras públicas, de fornecimento de bens e de prestação de serviços, ambas de 31 de março de 2004.

${ }^{26}$ As referências doravante feitas no texto reportam-se à Diretiva 2004/18 (“diretiva-mãe"), sendo muito similares às constantes da Diretiva 2004/17, relativa aos vulgarmente designados "setores especiais". 
relativa aos critérios de adjudicação, que explica quais as possibilidades de as entidades adjudicantes satisfazerem as necessidades dos públicos em causa, incluindo no domínio ambiental e/ ou social, desde que aqueles critérios estejam ligados ao objecto do contrato, não confiram à entidade adjudicante liberdade de escolha ilimitada, sejam expressamente indicados e respeitem os principios fundamentais referidos no Considerando (2)", a saber: as liberdades de circulação e os princípios da igualdade de tratamento (de que o princípio da não discriminação não é mais do que uma expressão particular), do reconhecimento mútuo, da proporcionalidade, da transparência, bem como na concorrência efetiva para a adjudicação dos contratos.

As Diretivas de 2004 integram vários Considerandos e preceitos relativos à promoção de políticas sociais e ambientais, ainda que, e na linha do que já era defendido pela Comissão, o leque de possibilidades de concretização de políticas ambientais através dos contratos públicos é substancialmente maior do que o que sucede no âmbito social.

Isso mesmo é notório quando confrontamos as disposições das Diretivas da década de 90, sobre o critério da "proposta economicamente mais vantajosa" com as correspondentes disposições das Diretivas de 2004, que, à semelhança das antecedentes, não incluem qualquer subcritério de índole social, inovando apenas na expressa referência à ligação ao objeto do contrato e à integração de características ambientais ${ }^{27}$.

Sem prejuízo, é de salientar que, e em sintonia com o teor do 28. Considerando, o art. 19. ${ }^{\circ}$ admite que "os Estados-Membros podem reservar a participação em processos de adjudicação de contratos públicos a oficinas protegidas ou reservar-lhes a execução desses contratos no âmbito de programas de emprego protegidos, quando a maioria dos trabalhadores em causa seja constituida por deficientes que, por força da natureza ou gravidade das suas deficiências, não possam exercer uma actividade profissional em condições normais", devendo tal constar do anúncio do concurso.

Um segundo aspeto digno de nota, e na linha do explicitado no $33 .{ }^{\circ}$ Considerando, consta do art. 26." que admite que "as entidades adjudicantes podem fixar condições especiais de execucãa do contrato desde que as mesmas sejam compativeis com o direito comunitário e sejam

\footnotetext{
${ }^{27}$ A título de exemplo, cfr. o art. 26. ${ }^{\circ}$ da Diretiva 93/36 e o art. 53. ${ }^{\circ}$ da Diretiva 2004/18.
} 
indicadas no anúncio de concurso ou no caderno de encargos, que podem, designadamente, visar condições de indole social e ambiental'. A este respeito, registe-se ainda a possibilidade de as entidades adjudicantes, cumpridas determinadas obrigações de informação, poderem solicitar aos concorrentes que "indiquem ter tomado em consideração, ao elaborarem as respectivas propostas, as obrigações (nacionais) relativas às disposições em matéria de proteç̧ão e condicões de trabalho em vigor no local onde a prestação será realizada ${ }^{28 "}$.

$\mathrm{Na}$ eventualidade da apresentação de "propostas anormalmente baixas", o que é especialmente relevante quando o critério de adjudicação é o do "preço mais baixo", a entidade adjudicante deve solicitar esclarecimentos, incluindo designadamente sobre o respeito das condições relativas à proteção e às condições de trabalho em vigor no local de execução das obras ${ }^{29}$.

Uma última nota para assinalar que, em 2010, a Comissão publicou um Guia de Boas Práticas, destinado a orientar as entidades adjudicantes na promoção de políticas sociais através dos contratos públicos ${ }^{30}$.

\subsection{A Reforma de 2014}

Logo no $2 .^{\circ}$ Considerando, assume-se a relevância da contratação pública na Estratégia Europa 2020, perspetivando os contratos públicos como instrumentos ou "alavancas" do mercado suscetíveis de promover um crescimento inteligente, sustentável e inclusivo, assegurando simultaneamente a utilização mais eficiente dos fundos públicos.

Uma das principais novidades da Reforma de 2014 que - para o tema que nos ocupa -, interessa destacar e que constitui um dos aspetos que melhor espelha a mudança de paradigma, a que acima aludimos, prende-se com a preferência,

\footnotetext{
${ }^{28}$ Cfr. art. $27 .{ }^{\circ}$.

${ }^{29}$ Cfr. art. 55. ${ }^{\circ}$

30 "Buying social - A Guide to Taking Account of Social Considerations in Public Procurement", Comissão Europeia, acesso em dezembro 15, 2017, http://ec.europa.eu/social/ BlobServlet?docId=6457\&langId $=$ en.
} 
manifestamente assumida pelo legislador ${ }^{31}$, atribuída à utilização do critério da "proposta economicamente mais vantajosa", sendo ainda de notar que, apesar de manter a designação tradicional, o legislador deixa claro que este critério de avaliação das propostas deverá ser interpretado como o critério da "melhor relação qualidade/preço" 32 . Isto sem prejuízo de se conceder ao Estado-Membro a liberdade de optar seja por uma total proibição da utilização do preço ou do custo como único critério de adjudicação seja pela sua admissibilidade em determinadas situações ${ }^{33}$.

Ora, é precisamente na utilização do "novo" critério da "proposta economicamente mais vantajosa" que se abre um leque de possibilidades na promoção de políticas sociais naquela que é a fase fulcral do procedimento pré-contratual - isto é, a fase da avaliação das propostas -, referindo-se expressamente que os subcritérios podem incluir, não apenas aspetos ambientais ${ }^{34}$, mas também aspetos sociais ${ }^{35}$. A isto acresce que a Reforma de 2014 dedica uma maior atenção à promoção das políticas sociais através dos contratos públicos, consubstanciada na previsão de um conjunto de medidas que, a seguir, procuraremos destacar, ainda que sem carácter exaustivo, por razões de limitação de espaço.

Particular atenção merece a referência ao emprego e trabalho, assumindo o legislador, no 36. ${ }^{\circ}$ Considerando, que "as entidades cujo objetivo principal seja a integração social e profissional podem desempenhar um papel significativo", o mesmo se aplicando a "outras empresas sociais cujo objetivo principal é apoiar a integração ou reintegração social e profissional das pessoas com deficiência e pessoas desfavorecidas, tais como desempregados, membros de minorias desfavorecidas ou grupos socialmente marginalizados". Porquanto estas entidades ou empresas podem não estar em condições de competir no mercado, admite-se que os Estados-

\footnotetext{
${ }^{31}$ Contrariamente ao que sucedia nas diretivas antecedentes, que previam os dois critérios, sendo que a opção entre um e outro era decidida pela entidade adjudicante.

${ }^{32}$ Cfr. $89 .^{\circ}$ e $90 .^{\circ}$ Considerandos e art. 67. ${ }^{\circ}$.

${ }^{33}$ Cfr. art. $67 .^{\circ}$, n. $^{\circ} 2,3 .^{\circ}$ parágrafo.

${ }^{34}$ Recorde-se que no que respeita ao critério de adjudicação, as diretivas de 2004 apenas incluíam expressamente as características ambientais, sem prejuízo de, no já mencionado acórdão Comissão/ França, de 26 de setembro de 2000, o Tribunal de Justiça ter deixado claro que a enumeração dos subcritérios da "proposta economicamente mais vantajosa" era meramente exemplificativa.

${ }^{35}$ Cfr. art. $67 .^{\circ}$, n. ${ }^{\circ} 2$.
} 
Membros possam reservar-lhes a participação em procedimentos pré-contratuais, ou ainda reservar-lhes a execução dos contratos no âmbito de programas de emprego protegido, ou ainda - o que é inovador - reservar-lhes a adjudicação de determinados $\operatorname{lotes}^{36}$ do objeto do contrato no âmbito do respetivo procedimento pré-contratual.

Para garantir o cumprimento das obrigações em matéria de direito ambiental, social e laboral ${ }^{37}$, o legislador determina que este deve ser efetuado ao longo do procedimento pré-contratual, designadamente aquando da verificação das situações de exclusão dos concorrentes e no âmbito da avalição das "propostas anormalmente baixas"38. Acresce que o cumprimento dessas obrigações deve também ser garantido em sede de execução do contrato, admitindo-se que possam constar das cláusulas contratuais ${ }^{39}$.

Alarga-se a utilização de rótulos, não apenas de natureza ambiental ${ }^{40}$, mas também de índole social ou outro, podendo as autoridades adjudicantes - quer nas especificações técnicas do objeto do contrato, quer no critério de adjudicação, quer nas condições de execução do contrato - exigir um rótulo de natureza social, desde que os requisitos da rotulagem digam exclusivamente respeito ao objeto do contrato, sejam objetivamente verificáveis e não discriminatórios, entre outras condições ${ }^{41}$.

\footnotetext{
${ }^{36}$ Cumpre referir que uma das novidades das Diretivas de 2014, especificamente orientada para promover o acesso das PME (vulgarmente consideradas como o "gigante oculto" da economia europeia) aos contratos públicos consiste na inversão do regime tradicional relativo à adjudicação por lotes. A regra tradicional apenas admitia, a título excecional, a adjudicação de um contrato por lotes; a regra vigente estabelece como regra geral a adjudicação por lotes, o que, implicando a divisão do objeto do contrato em lotes, promove e facilita o acesso das PME e consequentemente a adjudicação, no âmbito do mesmo procedimeto pré-contratual, a vários concorrentes, que podem inclusivamente concorrer e apresentar propostas em relação a apenas um ou alguns dos lotes. Cfr. Considerandos 78..$^{\circ}$ e $79 .^{\circ}$ e art. $46 .^{\circ}$ da Diretiva 2014/24. À semelhança do que temos vindo a fazer, limitamos as referências à Diretiva 2014/24 (também ela, a "diretiva-mãe"), sendo que as disposições constantes da Diretiva 2014/25 são substancialmente idênticas e salvaguardando as especificidades da Diretiva 2014/23 relativa às concessões.

${ }^{37}$ Essas obrigações podem resultar de leis, regulamentos, decretos e decisões, quer no plano nacional quer da União, bem como de convenções coletivas e acordos internacionais conformes com o direito da União ou ratificados por todos os Estados-Membros, respetivamente. Cfr. $40 .{ }^{\circ}$ Considerando e arts. 18. ${ }^{\circ}$, n. $^{\circ} 2,56^{\circ},{ }^{\circ} .^{\circ} 1$ e $57 .^{\circ}, n .^{\circ} 1$, alínea f) e n. ${ }^{\circ} 4$, alínea a). Cfr. ainda Anexo X.

${ }^{38}$ Cfr. art. $69 .^{\circ}$, n. ${ }^{\circ}$ 2, alínea d).

${ }^{39}$ Cfr. $37 .^{\circ}$ Considerando e art. $70 .{ }^{\circ}$.

${ }^{40}$ Já previstos nas Diretivas de 2004.

${ }^{41} \mathrm{Cfr} .75 .^{\circ}$ Considerando e art. $43 .^{\circ}$.
} 
Na linha da jurisprudência do TJ ${ }^{42}$, o legislador admite expressamente, nos 97. ${ }^{\circ}$ e 98. ${ }^{\circ}$ Considerandos, a possibilidade de prever, no critério de adjudicação ou nas condições de execução do contrato, o fornecimento ou a utilização de produtos de comércio justo, sendo, de todo o modo, essencial que "os critérios de adjudicação on as condições de execução dos contratos relacionados com os aspetos sociais do processo de produção digam respeito" ao objeto do contrato ${ }^{43}$. Incluem-se ainda, também no âmbito do critério de adjudicação da "proposta economicamente mais vantajosa" ou em sede de execução do contrato, a utilização de medidas destinadas a favorecer a promoção da igualdade do género e o aumento da participação das mulheres no mercado de trabalho, a conciliação da vida profisssional com a vida privada, assim como medidas de proteção da saúde do pessoal afeto ao contrato, do fomento da inserção social de pessoas desfavorecidas ou de grupos vulneráveis, o recrutamento de desempregados de longa duração e a implementação de ações de formação para desempregados ou jovens no decurso da execução do contrato, entre outras ${ }^{44}$.

Em jeito de conclusão, pode dizer-se que as Diretivas de 2014 possibilitam, através de um conjunto numeroso de medidas - umas de transposição obrigatória, outras de transposição facultativa - a implementação de uma contratação pública socialmente comprometida, em sintonia com a Estratégia Europa 2020, mas a sua concreta aplicação depende, em grande medida, das opções dos legisladores nacionais e das (boas) práticas das entidades públicas adjudicantes.

\footnotetext{
${ }^{42}$ A este respeito, revestem especial interesse algumas considerações vertidas no acórdão TJUE de 10 de maio de 2012, Comissão/Países Baixos, Processo C - 368/10, EU:C:2012:284.

${ }^{43}$ Em qualquer caso, a sua aplicação deverá ser feita em conformidade com a Directiva 96/71, tal como interpretada pelo Tribunal de Justiça, e como é salientado no $98 .^{\circ}$ Considerando.

${ }^{44}$ Cfr. 99. ${ }^{\circ}$ Considerando.
} 



\title{
A imprescindibilidade da democracia deliberativa na esfera local para uma ampliação na interlocução entre Estado e sociedade
}

\author{
Cynthia Gruendling Juruena*
}

RESUMO: O presente artigo visou abordar a democracia deliberativa e a sua imprescindibilidade na esfera local, para que assim possa haver uma ampliação no diálogo entre Estado e sociedade. Dessa forma, tratou-se as matrizes teóricas da democracia deliberativa, conferindo um enfoque ao referencial de Jürgen Habermas. Após, enfatizou-se a importância do espaço local na interlocução entre Estado e sociedade. Os resultados preliminares foram que há a necessidade de instrumentos que de fato possibilitem o processo democrático deliberativo. A metodologia de pesquisa utilizada na presente pesquisa foi o método hipotético-dedutivo, onde a hipótese testada foi se há essa imprescindibilidade da democracia deliberativa para ampliar a interlocução entre os cidadãos e o poder público.

PALAVRAS-CHAVE: democracia deliberativa - esfera local - Estado - sociedade.

ABSTRACT: The present article aimed to discuss deliberative democracy and its indispensability at the local level, so that there can be an expansion in the dialogue between State and society. In this way, the theoretical matrices of deliberative democracy were treated, giving an approach to the reference of Jürgen Habermas. Afterwards, the importance of local space in the interlocution between State and society was emphasized. The preliminary results were that there is a need for instruments that will in fact enable the deliberative democratic process. The research methodology used in the present research was the hypothetical-deductive method, where the hypothesis tested was if exists this indispensability of deliberative democracy to expand the interlocution between citizens and public authority.

KEYWORDS: deliberative democracy - local sphere - society - State.

\footnotetext{
* Mestre em Direitos Sociais e Políticas Públicas pela Universidade de Santa Cruz do Sul - UNISC.
} 


\section{Considerações iniciais}

O presente ensaio tem por escopo verificar, diante um enfraquecimento da representatividade parlamentar, a imprescindibilidade da democracia deliberativa para o fortalecimento da esfera local, a fim de que haja maior interlocução entre o Estado e a sociedade. Dessa forma, analisar-se-á as matrizes teóricas da democracia deliberativa, não sendo possível, entretanto, o esgotamento desse modelo. Será verificado certos aspetos desse processo de deliberação política democrática a partir de Jürgen Habermas.

Para mais, a partir do âmbito local, será referenciada a possibilidade de que haja, neste espaço, maior interlocução entre o Estado e a sociedade. Assim, tratar-se-á de que forma a esfera local impulsiona essa ampliação no diálogo dos cidadãos com o ente estatal.

O presente trabalho possui a problemática de verificar a importância de mecanismos de democracia deliberativa para estreitar as relações entre os cidadãos e o poder público, trabalhando com o locus do espaço local.

\section{Matrizes teóricas da democracia deliberativa}

A democracia deliberativa se consubstancia em um processo de deliberação política democrática, onde a participação da sociedade civil é incorporada à regulação da vida coletiva. Um dos principais referenciais deste modelo é Jürgen Habermas ${ }^{1}$, o qual aqui será adotado.

A democracia na conceção deliberativa é mais do que simplesmente exercer o seu voto, isto é, vai além de registrar as suas preferências. A partir do diálogo dos cidadãos, a democracia deliberativa busca que eles alcancem as melhores preferências que satisfaçam o interesse público ${ }^{2}$.

\footnotetext{
${ }^{1}$ Há outros expoentes na democracia deliberativa, como Joshua e John Rawls. ver: Joshua Cohen, "Deliberation and Democratic Legitimacy", in Debates in contemporary political philosophy: an anthology, eds. Derek Matravers e Jon Pike (Estados Unidos da América e Canadá: Routledge: 2003, 342-360); John Rawls, Uma teoria da justiça (São Paulo: Martins Fontes, 1997). No entanto, não é possível esgotar aqui as vertentes da democracia deliberativa, tendo se elegido o autor Jürgen Habermas.

${ }^{2}$ Frank Cunningham, Teorias da democracia: uma introdução crítica (Porto Alegre: Artmed, 2009), 119-120.
} 
Importa ressaltar que tanto a democracia participativa quanto a democracia deliberativa encontram-se no mesmo campo teórico, isto é, se ocupam da problemática de como instituir e conferir maior efetividade à participação pública e à abertura dos processos de decisão pública. Nesta senda, "[...] o conceito deliberativo remete a complexos conjuntos teóricos, com conotações fortemente normativas, enquanto que a participação implica aspectos sobretudos aplicativos"3.

O processo democrático será legítimo se permitir e encorajar a deliberação pública em questões específicas. Além disso, importa ressaltar que os cidadãos devem ser aptos para que, de forma livre e igualitária, alcancem preferências a partir do processo deliberativo e exercitem as habilidades necessárias para a participação nos fóruns ${ }^{4}$. Com isso, tem-se que a conceção de uma democracia deliberativa requer que os cidadãos, a partir de suas respetivas orientações, convirjam para um espaço público de discussão (fórum). Dessa forma, será tomada uma decisão legítima a partir de um debate público 5 .

Para a construção do processo democrático deliberativo de Habermas, o autor perpassa as conceções liberal e republicana, pois a democracia deliberativa irá surgir como uma outra via a esses modelos. Inclusive, as crises pós-68 fizeram com que houvesse uma desilusão com o modelo de democracia liberal, tendo-se a necessidade de um modelo democrático que incorporasse o poder local, democracia nos locais de trabalho, deliberação entre os cidadãos, dentre outros ${ }^{6}$.

É a partir do delineamento do que seria política, direito, democracia, e outros conceitos para as conceções liberal e republicana, que Habermas delineia o modelo deliberativo, no viés de que através da comunicação que o processo político alcançará resultados racionais ${ }^{7}$. Na perspetiva habermasiana, além de haver a necessidade

\footnotetext{
${ }^{3}$ Rogério Gesta Leal., "Demarcações conceituais preliminares da democracia deliberativa: matrizes habermasianas", in A democracia deliberativa como nova matriz de gestão pública: alguns estudos de casos. Santa Cruz do Sul, org. Rogério Gesta Leal (Santa Cruz do Sul: EDUNISC, 2011), 14-15.

${ }^{4}$ Frank Cunningham Teorias da democracia, 120- 121.

${ }^{5}$ Geraldo Tadeu Monteiro, "Democracia Deliberativa", in Dicionário de Filosofia do Direito, coord. Vicente de Paulo Barreto (Rio de Janeiro: Renovar, São Leopoldo: Unisinos, 2006), 197.

${ }^{6}$ Geraldo Tadeu Monteiro, "Democracia Deliberativa", 197.

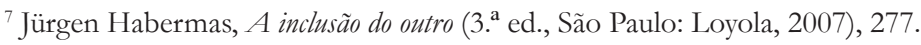


de uma participação dos cidadãos de forma livre e igualitária, deve-se haver um instrumento racional para guiar o processo democrático deliberativo.

Habermas, então, desenvolve a teoria do discurso, que seria o procedimento para o aconselhamento e a tomada de decisões. Este procedimento "[...] cria uma coesão interna entre negociações, discursos de auto-entendimento e discursos sobre a justiça, além de fundamentar a suposição de que sob tais condições se almejam resultados ora racionais, ora justos e honestos"s.

Neste contexto, o processo democrático deliberativo proposto por Habermas é entendido como um mecanismo de análise dos sistemas sociais e processos constitutivos da decisão, devendo ocorrer um compromisso comunicativo de entendimento e deliberação, para que, dessa forma, gere consensos legítimos. No entanto, para que haja a razoabilidade de uma conceção política, não se pode esperar dos cidadãos nenhum consenso se estes não estiverem dispostos a adotar um ponto de vista moral independente das distintas doutrinas compreensivas que cada um assume para si?.

Expostas as matrizes teóricas da democracia deliberativa e visto a sua importância para a interlocução entre os cidadãos e o Estado, será trabalhada a esfera local como o espaço mais propicio para que ocorra essa intercomunicação.

\section{A importância da esfera local na interlocução entre Estado e sociedade}

Analisada a matriz teórica do processo democrático deliberativo, de suas especificidades e de sua importância para que os cidadãos tomem parte em decisões públicas, verificar-se-á a importância da esfera local nessa interlocução entre Estado e sociedade, a qual será ampliada mediante a inserção de instrumentos deliberativos.

"Em particular, ao se deslocar boa parte das iniciativas do desenvolvimento para o nivel local, aproxima-se a decisão do espaço onde o cidadão pode efetivamente participar" ${ }^{\prime 10}$. Nesse sentido,

\footnotetext{
${ }^{8}$ Jürgen Habermas, A inclusão do outro, 278.

9 Jürgen Habermas, "Reconciliación mediante el uso público de la razón", in Debate sobre el liberalismo politico, Jürgen Habermas e John Rawls (Barcelona: Ariel, 1998).

${ }^{10}$ Ladislau Dowbor, Democracia econômica: alternativas de gestão social (Petrópolis: Vozes, 2008), 85.
} 
o espaço local assume significativa importância para que o cidadão se integre dos assuntos públicos.

Será no espaço municipal que o cidadão, o ator social, deixará o plano da abstração e passará a ser entendido conforme as especificidades e necessidades concretas daquela esfera a que ele pertence. É a partir do espaço local que será possível a atuação desses atores para a formação de decisões públicas, decorrentes de uma apropriação desse espaço pela sociedade ${ }^{11}$.O espaço local é importante para que ocorra essa interlocução entre os cidadãos e o poder público, visto que há as questões relacionadas à identidade, pertencimento e peculiaridades da esfera local.

Nesta senda, o espaço local "pode ser entendido como parte de um processo de reconstrução da esfera pública, orientado para a democratização da gestão de políticas públicas no país, o qual tem na descentralização um de seus componentes centrais" ${ }^{\prime 2}$. Devido à proximidade que essa esfera possui com o cidadão, o espaço público e a cidadania podem vir a se reconstruir, caso ocorra uma maior interlocução entre cidadãos e Estado diante os assuntos públicos.

Hermany ${ }^{13}$ assevera que a participação da sociedade "[...] se potencializa a partir de uma dimensão local, na qual se pode construir um efetivo processo de formação democrática e legitima das decisões públicas, sejam administrativas ou legislativas". E o mesmo pode se aferir do processo democrático deliberativo, onde se há um efetivo processo de formação democrática e legítima de decisões públicas. Dessa forma, tanto os mecanismos de participação como o de deliberação são fundamentais para este diálogo entre Estado e sociedade, se potencializando no espaço local.

A esfera local pode para muitos ser tido como um espaço simples, visto que abrange uma determinada localidade, mas é eficaz na manifestação de interesses e necessidades dos cidadãos ${ }^{14}$. Além do que, a partir desse locus pode haver maior controle social, participação pública, e, evidentemente, processos democráticos

\footnotetext{
${ }^{11}$ José Alfredo de Oliveira Baracho, O princípio de subsidiariedade:Conceito e evolução (Rio de Janeiro: Forense, 1996).

${ }^{12}$ Marta Ferreira Santos Farah, "Parcerias, novos arranjos institucionais e políticas públicas no nivvel local de governo", Revista de Administração Pública 35,1 (2001):132.

${ }^{13}$ Ricardo Hermany, (Re)Discutindo o espaço local: uma abordagem a partir do direito social de Gurvitch (Santa Cruz do Sul: Edunisc, 2007), 183.

${ }^{14}$ Ricardo Hermany, (Re)Discutindo o espaço local, 183.
} 
deliberativos. Neste sentido, a democracia local é fundamental, além de favorecer que as práticas de democracia participativa e deliberativa ali tenham um melhor espaço para o seu desenvolvimento.

O espaço público local se mostra, então, como o ambiente ideal para que ocorra a interação social e processos democráticos participativos e deliberativos, visto que na esfera local os cidadãos possuem maior contato com o poder público. Essa aproximação entre os cidadãos e o espaço local pode transformar essa interlocução de harmonia e de cooperação, basta que haja instrumentos disponíveis para a participação e que a mesma seja fomentada pelo Estado.

\section{Considerações finais}

A partir de um breve estudo do processo democrático deliberativo, destacouse que o espaço local é o locus ideal para que ocorra essa interlocução entre os cidadãos e o poder público. Isto porque normalmente as necessidades dos indivíduos se resolvem facilmente a partir da esfera local em que estão inseridos. Ademais, o cidadão possui maior proximidade com o espaço local, em virtude de uma questão de pertencimento.

Diante disso, se observou que deve ser incentivada maior participação e canais para a deliberação em assuntos públicos no espaço local, e isso ainda resultaria em uma reconstrução da cidadania, que se tornaria mais fortalecida com essas práticas.

Conclui-se que a deliberação pública, em determinadas questões, é de suma importância, em especial na esfera local, onde o cidadão se encontra mais próximo do poder público. Dessa forma, deve haver um incentivo em mecanismos de democracia deliberativa, para possibilitar uma ampliação nas relações entre Estado e sociedade. 


\section{A ineficiência da execução fiscal em números no Brasil}

\section{Elaine Gonçalves Weiss de Souza*}

RESUMO: Trata-se de uma análise quantitativa de dados numéricos fornecidos por órgãos oficiais a respeito da inadimplência no Brasil, principalmente no âmbito dos devedores de tributos federais. O crescimento das dividas e dos devedores é maior que os pagamentos dos montantes já devidos de anos anteriores. $O$ artigo discute os problemas que os dados revelaram: a) a ineficiência da execução fiscal na recuperação do crédito tributário, o que exige uma modificação urgente na legislação; b) a existência de tributos impagáveis que geram uma dívida ativa irreal, a qual quebra o princípio constitucional da isonomia.

PALAVRAS CHAVES: execução fiscal - ineficiência - números - Brasil.

ABSTRACT: This is a quantitative analysis of numerical data provided by official agencies concerning bad debt in Brazil, mainly in the context of the borrowers of federal taxes. The growth of debt and of debtors is bigger than the payments of amounts already due in previous years. The article discusses the issues that the data revealed: a) inefficiency of tax enforcement in the recovery of the tax credit, which requires an urgent modification in legislation; b) the existence of unpayable taxes that generate an unreal active debt, which breaks the constitutional principle of isonomy.

KEYWORDS: tax enforcement (execution) - inefficiency - numbers - Brazil.

* Doutoranda em Ciências Jurídicas Públicas na Universidade do Minho. 


\section{I.}

No Brasil, consoante dados do SERASA-EXPERIAN ${ }^{2}$, empresa privada reconhecida pelo Código Nacional de Defesa do Consumidor, Lei 8.078/90, art. 43. ${ }^{\circ}, 4^{\circ}$, como entidade de caráter público, em pesquisa realizada no ano de 2014 , foi identificado que quando destacadas as dívidas atrasadas há mais de noventa dias, e com valores acima de $\mathrm{R} \$ 200,00$ (duzentos reais) os inadimplentes brasileiros, pessoas físicas, totalizavam cerca de 35 milhões de pessoas, o equivalente a $24,5 \%$ de toda a população total do Brasil (e sem desconsiderar a população infantil).

Messias $^{3}$ explicita em dados que o valor do passivo tributário, em discussão na esfera administrativa no Brasil (ou seja, que não foram ainda objetos de ação de execução fiscal) em âmbito federal, totalizava no ano de 2013, aproximadamente US\$ 230 bilhões de dólares. Somam-se a este montante cerca de outros estimados US\$ 100 bilhões de dólares relacionados a casos emblemáticos já em discussão no judiciário, como sobre os temas referentes a preço de transferências de empresas controladas e coligadas no exterior, remessa de lucro ao exterior, contribuições sociais sobre instituições financeiras, inclusão das prestadoras de serviços no sistema não cumulativo e ágio (o que demonstra mais uma vez a insegurança jurídica diante de interpretações tão gravemente diferenciadas a ponto de representar indagações tributárias bilionárias, onde um posicionamento estatal pela administração ou pelo judiciário pode representar hecatombes em contas públicas ou privadas favorecendo inclusive a corrupção).

Com efeito, estão em discussões tributárias atualmente quase US $\$ 330$ bilhões de dólares, ou $15 \%$ do PIB brasileiro. Este número certamente é muito maior, uma vez que está sendo considerada na conta apenas a fração mais polêmica de temas, e somente em âmbito federal, dos casos em tramitação hoje no judiciário brasileiro. A dívida transmuda-se numa ficção, pois é impagável e irreal.

\footnotetext{
2 “Mapa da Inadimplência no Brasil em 2014”, SERASA, acesso em fevereiro 15, 2016, http:// www.serasaexperian.com.br/estudo-inadimplencia.

3 "Contencioso tributário brasileiro é muito superior ao dos EUA", Lorreine Messias, acesso em novembro 25, 2014, http://www.conjur.com.br/2013-nov-21/lorreine-messias-contencioso-tributariobrasileiro-superior-eua.
} 
Em parâmetros, nos Estados Unidos, por exemplo, segundo o Internal Revenue Service (IRS) ${ }^{4}$, agência americana responsável pela arrecadação fiscal em âmbito federal, o valor do passivo tributário em discussão alcançou a cifra de US\$ 40 bilhões em 2012, ou 0,2\% do PIB daquele país. Em termos de números de processos, o Brasil também fica à frente de outros países, são cerca 16 processos tributários em discussão atualmente para cada dez mil habitantes. Nos Estados Unidos e Austrália, estima-se que havia, em 2012, cerca de um processo tributário a cada dez mil habitantes 5 .

De acordo com a Procuradoria Geral da Fazenda Nacional - PGFN, o índice de recuperação do crédito tributário atrasado, quando este passou a ser protestado, passou num período de três anos, de 1\% para 19\%, ou seja, quase vinte vezes mais, que o crédito apenas enviado à execução fiscal ${ }^{6}$.

Os últimos dados estatísticos (balanço geral) sobre a dívida ativa, publicados pela União são do ano de 20117 , o que demonstra que até a transparência na detecção dos problemas não é muito eficiente. Em maio de 2015, o Departamento de Gestão de Dívida Ativa, ligado à PGFN informou que naquela data o valor inscrito em dívida ativa com a União já perfazia a quantia de aproximadamente um trilhão e meio de reais ${ }^{8}$.

No ano de 2016 a dívida ativa somente da União cresceu 14\% em relação ao ano anterior. Houve cerca de 1,5 milhão de novas inscrições em dívida ativa. No período, o valor de pagamentos foi menor que o valor de novas dívidas cadastradas, ou seja, o grau de recuperabilidade foi muito menor que o crédito inscrito em dívida ativa?.

\footnotetext{
${ }^{4}$ Disponível em: https://www.irs.gov.

5 "Contencioso tributário brasileiro é muito superior ao dos EUA", Lorreine Messias.

6 "Protesto de CDAs possui taxa de recuperação de 19\%", Procuradoria-Geral da Fazenda Nacional, acesso em novembro 17, 2016, http://www.pgfn.fazenda.gov.br/h_37806_interpgfn_site/noticias_ carrossel/protesto-de-cdas-possui-taxa-de-recuperacao-de-19.

7 “Dados Estatísticos da Dívida Ativa da União", Procuradoria-Geral da Fazenda Nacional, acesso em janeiro 15, 2017, http://www.pgfn.fazenda.gov.br/divida-ativa-da-uniao/dados-estatisticos.

8“Departamento de Gestão da Dívida Ativa Da União: Execução Fiscal”, Procuradoria-Geral da Fazenda Nacional, acesso em janeiro 15, 2017, http://www2.camara.leg.br/atividade-legislativa/ comissoes/comissoes-temporarias/especiais/55a-legislatura/pl-2412-07-execucao-da-divida-ativa/ documentos/audiencias-publicas/LUSINCIOLUCENAADAMS_Apresentao_Comisso_Maio2015. pdf.

9 "Dívida ativa da União aumenta 14\% em dez meses de 2016", Jornal do Comércio, acesso em janeiro
} 
Entre estes novos registros, cerca de 300 mil foram contribuintes devedores integrantes do programa de arrecadação simplificada, o "Simples Nacional", para pequenos empresários. E de outra ponta, em 2015, constatou-se que os quinhentos maiores devedores do país corresponderam a 37\% de tudo o que a União espera receber. E da dívida total deste quinhentos, só 11\% - R \$ 43 bilhões - estava suspenso por decisão judicial. Já em relação ao valor global, 90\% da Dívida Ativa da União estão judicializados, segundo a PGFN ${ }^{10}$. Em 2016, a situação se manteve muito semelhante ${ }^{11}$.

II.

Tais informações estatísticas auxiliam a demonstrar a importância de novos rumos para a cobrança dos tributos além de destacar a gigantesca problemática normativa e interpretativa existentes sobre as normas tributárias. Vê-se que no Brasil a execução fiscal é um esforço que não encontrou eco.

O tributo é visto como uma arma, e a racionalidade da cobrança pode entrar em choque com a quebra do contrato social. Rousseau explicou ${ }^{12}$ utilizando uma metáfora, que os políticos despedaçam a soberania de um país como desmembram os membros de um corpo, e depois não conseguem mais reunir as peças para reavivá-lo novamente. E esta separação do corpo é dividida em força e em vontade, em poder legislativo e em poder executivo, em justiça e em guerra, em administração interior e em poder de tratar com o estrangeiro, e notadamente, nos direitos de impostos.

A cobrança não pode ser exagerada, e sua efetividade deve ser exaltada. De nada adianta a um Estado gastar milhões para organizar uma justiça federal para, entre

15, 2017, http://jcrs.uol.com.br/_conteudo/2016/11/economia/531218-a-divida-ativa-da-uniaoaumentou-14-em-cerca-de-dez-meses.html.

10 "Fazenda divulga lista das 500 empresas que mais devem à União", Jornal do Comércio, acesso em janeiro 19, 2017, http://www.conjur.com.br/2015-out-14/fazenda-divulga-500-maiores-inscritosdivida-ativa-uniao.

11 "Novo Modelo de Cobrança da Dívida Ativa Da União", Procuradoria-Geral da Fazenda Nacional, acesso em janeiro 19, 2017, http:// fernandorodrigues.blogosfera.uol.com.br/files/2016/11/relatoriopgfn-divida-impostos-9nov2016.pdf.

12 "Do contrato social. Tradução de Rolando Roque da Silva", Jean Jacques Rousseau, acesso em novembro 21, 2016, 14. 
outras funções, realizar a cobrança tributária, mobilizar milhares de servidores para providenciar as execuções fiscais, ter procuradorias estruturas, se o retorno é pífio. Nestas condições, o Estado que não instituiu um tributo pagável, e que possa ser cobrado, é um Estado completamente desajustado e despedaçado, que não consegue se reajustar como na metáfora de Rousseau.

A inadimplência fiscal está também completamente interligada com a celeuma da sonegação fiscal, obviamente aí, imbricada com a corrupção ${ }^{13}$. Reproduz-se sistematicamente o desperdício de receitas públicas pela via da corrupção e, de outro, a perda de arrecadação por conta de receitas públicas não concretizadas ou postergadas, geradas pela sonegação ou ineficiência muitas vezes dolosa na recuperação dos créditos tributários.

Estudos da Federação das Indústrias do Estado de São Paulo (Fiesp) ${ }^{14}$ do ano de 2010 revelaram que a corrupção tem um custo médio anual entre 1,5\% a 2,6\% do PIB do Brasil, o que corresponderia, aproximadamente, segundo dados atuais, entre 79 bilhões e R\$ 137 bilhões, enquanto a sonegação resultaria em perdas de ordem de 10,1\% do PIB anual. Em tal medida, isso equivaleria a R \$ 518,2 bilhões levando em conta o PIB de 2014, segundo estudos do Sindicato dos Procuradores da PGFN ${ }^{15}$.

Para qualquer estatística que se observe, a inadimplência pública ou privada somente cresce. A conclusão mais forte para o Brasil é a de que o tributo não quitado no prazo legal, mesmo com o ajuizamento da execução fiscal, dificilmente será recuperado pelo Estado. Além disso, a recalcitrância do contribuinte para com

\footnotetext{
${ }^{13}$ Sobre a corrupção Tocqueville dizia que "O que é necessário recear, aliás, não é tanto a visão da imorabilidade dos grandes, mas a imoralidade condu₹̨indo à grandiosidade", ou seja, a admiração e inveja aos indivíduos que como simples cidadãos saem de suas classes e alcançam em poucos anos a riqueza e o poder com cargos púbicos. Alexis Tocqueville, Da democracia na américa (Trad. Maria da Conceição Ferreira da Cunha, Porto: Rés-Editora, 1978.), 74.

14 “Relatório Corrupção: custos econômicos e propostas de combate", Federação das Indústrias do Estado de São Paulo (FIESP), acesso em julho 16, 2016, https:/ /bvc.cgu.gov.br/bitstream/123456789/3113/1/ relatorio_corrupcao_custos_economicos.pdf >.

15 “Sonegação no Brasil - Uma Estimativa do Desvio da Arrecadação do Exercício de 2014”, Sindicato Nacional dos Procuradores da Fazenda Nacional (SINPROFAZ), acesso em novembro 21, 2016, www. quantocustaobrasil.com.br/artigos/sonegacao-no-brasil $\%$ E2\% $\% 0 \%$ 3uma-estimativa-do-desvio-daarrecadacao-do-exercicio-de-2014..
} 
o Fisco cresce tanto quanto as dívidas entre os particulares. O devedor do Fisco costuma ser alguém que já está a dever muito ao privado.

Identificada a falta de eficiência na cobrança fiscal, é certo que a legislação precisa ser melhorada a fim de buscar caminhos mais competentes. Este aprimoramento é imprescindível para que o princípio constitucional da isonomia, o qual também figura como um direito fundamental, se consolide. Não é possível cobrar de quem já esteja vivendo no limite do mínimo existencial fiscal. Cobrar de alguns contribuintes, e deixar que outros apostem na inoperância estatal para livrarem-se do pagamento é um atestado de desigualdade. Contudo, não há como cobrar aquilo que, como se vê, não pode ser pago. E também não é razoável organizar um aparato administrativo custoso e complexo para a cobrança de tributos, cujo êxito na exigibilidade é muito baixo. Assim, novas alternativas devem urgentemente serem construídas, seja na área da instituição justa e equilibrada do tributo, seja na forma de sua cobrança eficaz 


\title{
A Lei Anticorrupção Brasileira a partir de sua perspetiva histórica
}

\author{
Fábio Roque Sbardellotto*
}

RESUMO: O fenômeno da corrup̧ça não se limita a determinados espaços territoriais, grupos sociais ou atividades. Também não é hodierno, porquanto registrado em todos os periodos históricos. O que chama a atenção e merece consideração é o tratamento conferido ao problema, que deixou de ser artesanal e quase lúdico para exigir postura acadêmica e legislativa profilática, moderna e multidisciplinar. Por isso, propõe-se uma abordagem do tema em seu contexto bistórico e atual, notadamente a partir de postulados advindos de tratados e convenções internacionais, o que proporcionou, no Brasil, o surgimento da identificada Lei Anticorrupção Empresarial, contendo institutos precursores e alvissareiros, se postos em prática.

PALAVRAS-CHAVE: corrupşão - lei anticorrupção empresarial - boa administração.

ABSTRACT: The phenomenon of corruption is not limited to certain territorial spaces, social groups or activities. Nor is it modern, since it is recorded in all historical periods. What draws attention and deserves consideration is the treatment given to the problem, which has ceased to be artisanal and almost playful to demand prophylactic, modern and multidisciplinary academic and legislative posture. Therefore, it is proposed to approach the theme in its historical and current context, especially from postulates derived from international treaties and conventions, which in Brazil provided the emergence of the identified Business Anti-Corruption Law, containing precursor and alvissareiros institutes, if put into practice.

KEYWORDS: corruption - business anti-corruption law - good governance

* Diretor da Faculdade de Direito da Fundação Escola Superior do Ministério Público do Rio Grande do Sul - FMP. 


\section{Introdução}

A prática de atos corruptivos é um fenômeno histórico e multifacetado ${ }^{1}$, que a despeito de outras mazelas sociais, sempre vitimou a coletividade e privou os cidadãos da tão almejada dignidade da pessoa humana. Isso porque vultosos recursos criminosamente desviados do erário, notadamente, fazem falta para a erradicação da pobreza ou ao menos para a elevação dos índices de desenvolvimento humano e a implementação dos tão almejados e necessários direitos sociais. Importante se ter em vista as acentuadas desigualdades sociais vividas no Brasil e no mundo, com multidões passando fome e vivendo ainda em condições de miséria, sem alimento, educação, segurança, saúde e outras necessidades básicas. Ou mesmo direitos sociais que não são implementados ou mesmo são retirados a pretexto da falta de recursos.

Desde longa data enfatiza-se a necessidade de um novo paradigma no enfrentamento das práticas lesivas ao erário e à sociedade, incluindo a corrupção, para que se possa implementar os direitos fundamentais sociais e proporcionar dignidade aos cidadãos ${ }^{2}$.

Ocorre que o tema daquilo que hoje se denomina de corrupção historicamente não assumia tamanha relevância, sendo abordado pelas ciências criminais como crimes do colarinho branco ou cifra dourada da criminalidade, ou mesmo macrocriminalidade, notadamente com um viés criminal.

Nesse panorama, alvissareira a entrada em vigor, no Brasil, da Lei n. ${ }^{\circ} 12.846$, em 1. ${ }^{\circ}$ de agosto de 2013, denominada Lei Anticorrupção Empresarial, que incorporou ao sistema jurídico brasileiro um conjunto de normas e institutos precursores, voltados à prevenção e ao combate à corrupção por atos decorrentes das relações mercadológicas com o Estado. Visa ineditamente ao combate à corrupção originada

\footnotetext{
${ }^{1}$ Sobre os fundamentos filosóficos e políticos do fenômeno da corrupção, em sua perspectiva clássica e moderna, demonstrando o caráter multissetorial e complexo das práticas corruptivas, ver Rogério Gesta Leal, "Patologias corruptivas nas relações entre Estado, Administração Pública e Sociedade: causas, consequências e tratamentos" (Santa Cruz do Sul: EDUNISC, 2013) 14-47.

${ }^{2}$ Fábio Roque Sbardellotto, "Direito Penal no Estado Democrático de Direito: Perspectivas (re)legitimadoras." (Porto Alegre: Livraria do Advogado, 2001) 214-215.
} 
das pessoas jurídicas, refletindo o anseio dos organismos internacionais que, desde longa data, já manifestavam a necessidade dos os Estados estabelecerem normas destinadas ao combate às práticas corruptivas.

Com a entrada em vigor da Lei Anticorrupção Empresarial, verificou-se o surgimento de um novo paradigma estratégico e cultural para o enfrentamento do tema, com o investimento em práticas cautelares de prevenção em detrimento do viés sobremaneira punitivo. Ademais, a novel legislação representou uma virada substantiva quanto à política de enfrentamento do problema da corrupção. Centrou suas baterias na responsabilização das pessoas jurídicas em suas relações com o erário, o que inexistia no Brasil e, diga-se, em boa parte dos países, até então.

\section{O tratamento histórico-tradicional do fenômeno da corrupção}

É histórica a preocupação acadêmica e normativa voltada a priorizar a responsabilização da pessoa física quando da prática de atos corruptivos. Também tradicional é a preocupação criminológica acerca do tema sob o viés individualista, sem atentar para os reflexos sociais ou transindividuais do problema. Tal cultura decorre ainda das influências do Estado Liberal, marcante para o fomento da expressão individualista, que tem seu marco histórico na Revolução Francesa. Desde então, sob este modelo, buscou-se inverter as posições anteriormente vigentes na relação de primazia Estado-indivíduo para uma performação indivíduo-Estado. Daí poder-se falar em um perfil social e estatal liberal-individualista-normativista. Nesse período até recentemente, o tema das condutas sociais que caracterizassem práticas corruptivas, com lesão ao erário ou mesmo de consequências coletivas, não mereceu preocupação acadêmica ou mesmo legislativa adequada. $\mathrm{O}$ tratamento de questões desse jaez era restrito aos denominados "crimes do colarinho branco", "ifira oculta da criminalidade" ou mesmo macrocriminalidade, com performace "romântica" ou "artesanal". Não se via preocupação do Estado em prevenir e reprimir as infrações penais e/ou administrativas de alta lesividade social como fenômeno acentuadamente lesivo e multifacetado, com intensos reflexos sociais, polícitos, econômicos e jurídicos. 
Até meados do século passado, a criminologia foi precursora em desenvolver atenção científica sobre o tema dos desvios nas relações privadas-estatais, entre pessoas físicas ou jurídicas. Elegeu a obra de Cesare Lombroso, O Homem Delinqüente, de 1876, como o marco de seu surgimento. Lola Aniyar de Castro assevera que o segundo momento mais importante para a criminologia constitui-se no discurso pronunciado por Sutherland perante a Sociedade Americana de Criminologia, em 1949, no qual definiu o conceito de crime do colarinho branco (white-collar crime) ${ }^{3}$, que foi mais tarde desenvolvido pelo autor ${ }^{4}$ em razão de uma série de violações da Lei Antitrust, nos Estados Unidos, por diversas corporações minerais e comerciais privadas, além de corporações de serviço público de energia e luz elétrica daquele país. Sutherland destacou que as companhias produtoras de aparelhos elétricos mais importantes dos Estados Unidos haviam dividido o território em quatro partes, cada uma sob o domínio individual. Com isso, arbitrariamente, sem relação com os custos de produção ou com a oferta e procura, em detrimento dos consumidores, tais companhias fixavam preços exorbitantes, explorando o mercado. Os conchavos entre elas eram realizados em hotéis, clandestinamente, com a utilização de uma espécie de jargão característico, para dissimular o conteúdo dos acordos. "Em vez de falar em suas cartas, de listas de preços ou lista de pessoas que compareciam às reuniões, falavam em lista de cartões de natal. Telefonavam-se geralmente de telefones públicos e, ao se registrarem nos hotéis, não nomeavam as companhias representadas e assim por diante". Estas características foram utilizadas por Sutherland para definir os delitos do colarinho branco, em um primeiro momento, não apenas como aquelas condutas sancionadas no Código

\footnotetext{
${ }^{3}$ Sobre a origem do conceito de colarinho branco, Alberto Zacharias Toron, "Crimes de colarinho branco. Os novos perseguidos?” Revista Brasileira de Ciências Criminais 7: 28(1999): 75. esclarece que “Antes da contribuição de Sutherland, a sociologia já utilizava a expressão white collar (colarinho branco) para designar os trabalhadores não braçais em contraste com as vestimentas blue collar, os macacões, dos obreiros". Ressalta que Sutherland, "ao fixar o conceito de crimes do colarinho branco como aqueles cometidos por pessoas de elevada condição socioeconômica, o fez, como expressamente advertiu, por comodidade. Pois, o conceito não pretendia ser definitivo, mas visava a apenas chamar a atenção sobre os delitos que normalmente não adentravam o âmbito da criminologia". Odone Sanguiné assevera que a literatura sociológica empregou a expressão "colarinho branco (Wright Mills)" pela primeira vez para descrever a classe média norte-americana, apresentada como formadora da "elite do poder. Odone Sanguiné, "Função simbólica da pena.” Fascículos de Ciências Penais 4: 2(1991):18.

${ }^{4}$ Edwin H Sutherland, "Il crimine dei coletti bianchi." (Milão: Giuffré, 1987).
} 
Penal, mas também o que é sancionável pelo Código Penal, isto é, o que causa um dano importante aos interesses da comunidade, ainda que não previsto no aludido Código, bastando que se encontre em leis penais especiais ${ }^{5}$.

É nesse contexto histórico e dogmático que se insere o fenômeno das práticas corruptivas como fator de hodierna preocupação mundial. Se até meados do século passado verificava-se atenção acadêmica e até jurídica muito tênue sobre o problema no âmbito do Direito, que também utilizava denominações como crimes do colarinho branco, cifra dourada da criminalidade ou macrocriminalidade, passou-se a observar no plano dogmático e jurídico acentuada ênfase sob o prisma do combate daquilo que se passou a chamar de corrupção. Suas proporções e lesividade ao patrimônio público, à economía, política e reflexos sociais, bem como sua disseminação em todos os setores e níveis, a despeito da repercussão midiática, motivaram movimentos legislativos nos quais os Estados e Organismos Internacionais ${ }^{6}$ passaram a procurar uma resposta adequada ao problema. A despeito dos aspetos positivos desta progressiva amplitude da transparência material e formal (publicidade ampliada, mais leis, tratados, convenções, pactos, sentenças judiciais, pesquisas acadêmicas e procedimentos administrativos que se ocupam do tema) que surge em torno da corrupção, gerando até reflexos sobre a opinião pública de massa, resgatando a capacidade de indignação quanto ao problema, o que se afigura importante, isto tampouco dá conta da complexidade deste fenômeno ${ }^{7}$.

Leal, sobre o tema, assevera com absoluta propriedade: "Por outro lado, o debate sobre corrupção tem se centrado nos seus aspectos econômicos e jurídicos no Ocidente, todavia o problema é quando estes âmbitos de enquadramento restringem outras abordagens que dizem com causas e consequências para além deles, deixando de se reconhecer que, em verdade, que a corruption destroys the fundamental values of buman dignity and political equality, making it impossible to guarantee the rights to life, personal dignity and equality, and many other rights. É fácil entender

\footnotetext{
${ }^{5}$ Lola Aniyar de Castro, “Criminologia: Da reação social.” (Rio de Janeiro: Forense, 1983) 73.

${ }^{6}$ Veja-se pesquisa da Transparência Internacional, que é reveladora sobre os alarmantes índices de práticas corruptivas em diversos países, incluindo alguns de destaque por seu desenvolvimento econômico e social. https://www.transparency.org.

${ }^{7}$ Leal, "Patologias corruptivas", 9.
} 
que tais restrições de compreensão do fenômeno sob comento também são decorrência do foco e da intensidade das violações econômicas e jurídicas que a ele provoca, pois ocorre mesmo o que Klitgaard chama de capture of the state by elites and private interests. É possivel diferenciar entre corrupção provocada para ganhos públicos e ganhos privados? Ou mesmo entre corrupção provocada pelo setor público e pelo setor privado?"

Em especial a partir de movimentos internacionais gestados em organismos multinacionais, verifica-se uma virada hermenêutica no sentido de despertar para o fenômeno da corrupção no setor privado em suas relações mercadológicas e na esfera de suas relações com a Administração Pública como fenômeno de alta lesividade social, política e econômica, conforme já ressaltado, que precisa ser combatido. Perceptível a existência de movimentos transnacionais e internos na direção do estabelecimento de mecanismos normativos e axiológicos destinados ao combate à prática corruptiva, em todos os seus níveis, mas sempre com a preocupação da defesa do erário que, em última análise, se reflete na implementação dos direitos sociais fundamentais ainda deficitários na maior parte dos países.

A partir de uma mobilização internacional (notadamente 6. ${ }^{a}$ Covenção Interamericana contra a Corrupção de 1996, a Convenção das Nações Unidas contra a Corrupção - Convenção de Mérida de 2003, a Convenção sobre o Combate da Corrupção de Funcionários Públicos Estrangeiros em Transações Comerciais Internacionais da OCDE, de 23 de maio de 1997), culmina-se, no Brasil, com o surgimento da Lei Anticorrupção n. ${ }^{o}$ 12.846/2013, absolutamente precursora no sentido da prevenção e combate ao fenômeno da corrupção oriunda das empresas em sua relação com o poder público.

Este diploma legal fez emergir uma gama de ferramentas que ainda deverão ser implementadas, mas certamente muito valiosas aos fins da prevenção-combate à corrupção. Trata-se de instrumentos modernos e alguns deles pouco utilizados em muitos países. A Lei Anticorrupção n. ${ }^{\circ}$ 12.846/2013 introduziu um modelo no qual se busca estancar o mal da corrupção em uma de suas vertentes orgânicas que é o setor privado, notadamente as empresas quando de suas relações mercadológicas com o poder público. 
Nos limites deste extrato, é possível informar que a nova Lei Anticorrupção apresenta três instrumentos absolutamente inovadores e úteis sob a perspetiva da prevenção e combate às práticas corruptivas oriundas das pessoas jurídicas. São os institutos da responsabilidade civil e administrativa objetiva, os procedimentos de compliance e os acordos de leniência. A responsabilidade objetiva da pessoa jurídica por atos corruptivos na relação com o poder público é instituto inédito sob este viés, e poderá representar um grande avanço para os fins da aludida Lei. Quanto ao instituto do compliance, no Brasil, é absolutamente inédito, e certamente também será eficaz em termos preventivos à corrupção. Também os acordos de leniência, que já existiam, agora foram estendidos para as relações corruptivas específicas das empresas com o poder público, em paralelo a outros instrumentos como a colaboração premiada de extrema valia. São ferramentas inovadoras e eficazes para os fins propostos e, sobremaneira, em virtude dos reflexos que tais procedimentos podem representar no combate à corrupção e na efetivação das políticas públicas destinadas à implantação dos Direitos Sociais Fundamentais, tão necessários em favor dos cidadãos brasileiros.

\section{Considerações finais}

Portanto, se a corrupção é um fenômeno que não se limita a determinadas regiões, povos ou atividades, sendo altamente lesivo ao Estado e à sociedade em todos os seus fundamentos, a existência de políticas públicas preventivas é um dos caminhos a serem trilhados para se mitigar a sua prática e seus efeitos, sem prescindir, evidentemente, de ações corretivas. Após a superação da fase artesanal no trato de questões de alta lesividade ao erário, à sociedade, às instituições democráticas e ao próprio mercado, vislumbra-se com a Lei n. ${ }^{\circ} 12.846 / 2013$ uma nova perspetiva para, finalmente, termos instrumentos eficazes para a prevenção e o combate das práticas corruptivas em uma de suas origens mais comuns, isto é, a atuação das pessoas jurídicas em sua relação com o Estado. 



\title{
Ações afirmativas de gênero e a sua eficácia na garantia dos direitos das mulheres no cenário político brasileiro
}

\author{
Fernanda de Andrade Freire Lima*
}

RESUMO: As propostas de ação afirmativa que visam o estabelecimento de cotas eleitorais representam um desencanto democrático e demonstram que a mera igualdade formal é insuficiente. Embora as cotas possibilitem a participação de mulheres nos partidos políticos, se elas ou os partidos não demonstram interesse em questões de gênero, tem-se como consequência a inabilidade das cotas para a garantia da igualdade. O trabalho tem o objetivo de analisar brevemente esta questão, assim como apresentar algumas soluções para o problema, como a participação das mulheres em movimentos da sociedade civil e a educação de gênero desde a infância.

PALAVRAS-CHAVE: cotas - democracia - igualdade - género - politica.

ABSTR ACT: The affirmative actions proposals that aim to establish electoral quotas represent a disappointment with democracy and demonstrate that formal equality is not enough. Although the quotas enable the women's participation in the political parties, if they or the parties don't show interest in gender issues, the result is the inability of quotas to assure equality. The paper intends to briefly analyze this matter, as well as to present some possible solutions to the problem, like the women's participation in social movements and the gender education since childhood.

KEYWORDS: quotas - democracy - equality - gender - politics.

${ }^{*}$ Mestranda em Direitos Humanos e em Direito da União Europeia na Universidade do Minho. Membro não Doutorado do Centro de Estudos em Direito da União Europeia - CEDU. 
As democracias mais desenvolvidas são aquelas que mais têm respeito pelas minorias. Assim, para que as democracias contemporâneas sejam genuinamente inclusivas deve haver a preocupação de que os direitos fundamentais ultrapassem o âmbito normativo, ou seja, que passem do plano formal para a concretização material. As ações afirmativas, por exemplo, demonstram que a mera igualdade formal é insuficiente e que ela perpetua e legitima a desigualdade substantiva.

As cotas eleitorais para mulheres são resultado dessa constatação e representam um desencanto com o ideal de democracia, pois durante muito tempo as minorias reivindicaram o acesso aos direitos individuais e políticos prometidos. Os princípios democráticos passam a ser repensados quando há a constatação da sua aplicação prática insatisfatória e, consequentemente, da exclusão de grupos que compõem a sociedade, como as mulheres ${ }^{1}$.

No Brasil, o advento do voto feminino veio em 1932, mas a participação política das mulheres brasileiras foi praticamente nula até o fim da década de 1980, pois o direito ao voto foi suspenso durante dois períodos totalitários, o Estado Novo (19371945) e a ditadura militar (1964-1985).

Contudo, mesmo após a redemocratização e a promulgação da Constituição em 1988, a qual extinguiu completamente, pelo menos no plano formal, a desigualdade de gênero, até o ano de 2015 as mulheres não conseguiram ocupar mais de 10\% das cadeiras da Câmara Federal e mais de 16\% das cadeiras do Senado Federal. Diante da discrepância que continua a existir quanto à participação das mulheres na política, as ações afirmativas passaram a ser vistas como uma solução para o problema.

A Conferência Mundial sobre a Mulher de Beijing, realizada em 1995, trouxe definições importantes que influenciaram o estabelecimento da política de cotas no Brasil e em outros países. Em Beijing, os Estados reconheceram que os direitos das mulheres são direitos humanos e que o empoderamento da mulher e sua plena participação em situação de igualdade em todas as esferas sociais, inclusive nos processos de tomada de decisão e com acesso ao poder, são fundamentais para o alcance da igualdade, do desenvolvimento e da paz.

\footnotetext{
${ }^{1}$ Luis Felipe Miguel, "Teoria Política Feminista e Liberalismo: o caso das cotas de representação" Revista Brasileira de Ciências Sociais 15,44 (2000): 92.
} 
Após o encontro, o Brasil empreendeu esforços para mitigar a desigualdade de gênero na política. Assim, em 1997, foi elaborada e promulgada a Lei 9.504/97, determinando que cada partido ou coligação deveria reservar o mínimo de trinta por cento e o máximo de setenta por cento para candidaturas de cada sexo. No entanto, não houve um aumento efetivo das candidaturas femininas, o que pode ser justificado pela não obrigatoriedade do preenchimento das cotas, já que o entendimento prevalecente era no sentido de que as vagas estavam apenas "reservadas" para mulheres e o preenchimento real não era necessário².

Em 2009, a Lei 12.034/09 modificou a redação da Lei 9.504/97 e substituiu a obrigação de "reservar" pela obrigação de preencher efetivamente o mínimo de trinta por cento e o máximo de setenta por cento para candidaturas de cada sexo. Ainda que agora prevaleça a compreensão de que há obrigatoriedade no preenchimento das vagas, o que frequentemente ocorre é o descumprimento da obrigação, pois não existe sanção a ser aplicada ao desrespeito da lei nesse caso.

As cotas para mulheres nas candidaturas são chamadas cotas de representação. Atualmente, há uma proposta de emenda constitucional (PEC), já aprovada no Senado e em tramitação na Câmara, que tem o objetivo de implementar as chamadas cotas de legislatura, ou seja, a reserva de vagas para as mulheres no parlamento.

$\mathrm{O}$ advento das cotas representa uma desilusão com a prática política tradicional. Tal desengano provocou o afastamento da clássica "política de ideias" e a aproximação da "política de presença". A "política de ideias" julga que a identidade do representante não possui nenhuma relevância, desde que suas propostas políticas incorporem as demandas consideradas relevantes. Já a "política de presença" nasce da decepção causada pelos representantes, incapazes de protegerem as minorias3. Para a "política de presença", uma representação apenas das ideias políticas do eleitorado não é justa. A representação é legítima quando também estão representadas as diversas

\footnotetext{
${ }^{2}$ Eneida Desiree Salgado, Guilherme Ataides Guimarães e Eric Vinicius Lopes Costa Monte-Alto, "Cotas de gênero na politica: entre a história, as urnas e o parlamento", Periódico do Núcleo de Estudos e Pesquisas sobre Gênero e Direito 3 (2015): 167-168.

${ }^{3}$ Miguel, "Teoria Política Feminista e Liberalismo", 92 e 95.
} 
características dos cidadãos que compõem a sociedade como gênero, raça e etnia ${ }^{4}$.

Espera-se das mulheres que conseguem chegar a ocupar um cargo legislativo que defendam interesses das mulheres e façam políticas públicas para as mulheres. É uma espera quase que intuitiva, mas, infelizmente, as cotas apenas servem para que as mulheres sejam eleitas. Uma vez que isso ocorre, não há garantia de que o trabalho delas será voltado para a proteção dos direitos das mulheres.

Existem defensores ferrenhos da ideia de que a representação numérica das mulheres produz mudanças na sua representação substantiva. No entanto, nos países em que o parlamento conta com mais de 15\% de mulheres, a feminização da legislatura não produziu mudanças significativas no que os partidos e os governos fazem. Mulheres na política não necessariamente defendem um posicionamento feminista 5 .

Exemplo disso é o recém-criado Partido da Mulher Brasileira (PMB), que se apresenta como meio de maiorinclusão das mulheres na política, mas não busca defender interesses específicos das mulheres. O partido pronuncia-se como antifeminista e defende a volta da mulher ao seu devido lugar, como elemento agregador da família. Ainda, dos vinte deputados do partido eleitos, apenas dois são mulheres.

Aliás, para algumas mulheres, ganhar uma eleição e manter o cargo significa justamente afastar-se de pautas feministas. Foi o que a ex-presidente Dilma Roussef fez, pois na primeira campanha defendia, inicialmente, assuntos caros ao feminismo e de viés progressista, como a legalização do aborto, mas foi obrigada a voltar atrás quando a aliança com setores conservadores foi necessária para garantir a vitória e, posteriormente, a governabilidade.

Os interesses dos representantes políticos são mais definidos pela filiação aos partidos do que pelo sexo. A forma como as pessoas entram na política e engajamse na atividade política determina o seu aprendizado político e portanto molda seus interesses e suas habilidades. O senso de que as mulheres na política devem

\footnotetext{
${ }^{4}$ Anne Phillips, Democracy and the Representation of Difference and The Politics of Presence: Problems and Developments (Aalborg: Aalborg Universitet, 2000), 19.

${ }^{5}$ Andrea Cornwall e Anne Marie Goetz, "Democratizing Democracy: Feminist Perspectives", Democratization 12,5 (2005): 784.
} 
representar interesses femininos e têm um dever de prestação de contas com o eleitorado feminino é comum na opinião pública. No entanto, elas têm um dever com a linha seguida pelo partido e com os seus eleitores. A ação afirmativa para trazer mais mulheres para o espaço político não faz com que os partidos tenham interesse em problemas de desigualdade de gênero ou ajudam a construir um eleitorado mais consciente desses problemas ${ }^{6}$.

As cotas permitem que as mulheres participem nos partidos políticos, mas se estes não têm um programa explicitamente preocupado com questões de gênero, não há garantia de que os interesses das mulheres serão representados e, assim, as cotas como instrumento de igualdade de gênero são um tiro no escuro.

A ausência de impacto das cotas de gênero quanto à presença de mais argumentos feministas na política relembra que os interesses representados pelos parlamentares são aqueles bem preparados e organizados pelos partidos a que pertencem ou aqueles exigidos por grupos que fazem lobby político, oferecendo recursos financeiros para fazer avançar interesses próprios. A expectativa de que o sexo dos representantes determine seus interesses desconsidera que os políticos têm o dever de accountability, ou seja, de cumprir o programa dos seus partidos.

Assim, as cotas de gênero na política, sejam elas de representação ou de legislatura, apesar de serem um meio para garantir uma maior participação das mulheres nos espaços legislativos, não garantem que as mulheres ocuparão esses espaços para pensarem políticas para as mulheres. É ingênuo considerar que o simples fato de mais mulheres serem parlamentares resolve os problemas de desigualdade de gênero.

As mulheres continuam marcadas pelos estereótipos tradicionais sim, infelizmente. É claro que a sociedade avançou muito quanto aos direitos das mulheres, mas o ranço conservador e patriarcal ainda permanece. Os fatos de mais mulheres terem cargos no Legislativo e de o Brasil ter tido sua primeira presidente não são suficientes ainda para legitimar no inconsciente coletivo a ocupação dos espaços políticos por mulheres. Tais espaços são ainda vistos como essencialmente masculinos e os homens são considerados como melhores governantes.

\footnotetext{
${ }^{6}$ Cornwall e Goetz, "Democratizing Democracy”, 785.
} 
Um exemplo que pode ser dado sobre isso é a demonização que a imprensa e a população brasileiras fizeram da ex-presidente Dilma Roussef e a consequente bajulação da nova primeira dama, Marcela Temer. Dilma sofreu com críticas que tinham relação direta com a sua condição de mulher, foi chamada de louca, histérica, feia, falaram mal de suas roupas, fizeram piada com a suposta falta de feminilidade da presidente, com o fato dela não ter marido e levantaram suspeitas sobre a sua orientação sexual. Nenhuma dessas "críticas" têm relação de fato com as políticas adotadas em seu governo.

Por outro lado, após o impeachment, assumiu em seu lugar o vice-presidente Michel Temer e ele trouxe consigo o sonho de muitos brasileiros que criticavam Dilma: uma primeira-dama. Mas não só. Uma primeira-dama bela, recatada e do lar, como assim a descreveu a revista Veja em uma matéria que exalta as qualidades de Marcela Temer como mulher dedicada a cuidar do marido, do filho, da mãe e de sua beleza, claro. A clara tentativa da revista de vender a imagem de uma mulher ideal que fica em casa, que é alheia aos assuntos políticos, que cuida da família, que é o extremo oposto da ex-presidente, obviamente não passou despercebida pelas feministas e pelos setores mais progressistas da sociedade.

É evidente que a presença de mais mulheres na política alarga e aprofunda o projeto de democracia. No entanto, é necessário reconhecer que a busca por igualdade e justiça social não se resume a mais representatividade nas arenas políticas, mas também há a necessidade de democratização em outros domínios e instituições, incluindo a esfera privada.

O crescimento das organizações da sociedade civil dá às mulheres a possibilidade de exercerem influência no processo político de fora das instituições políticas formais. As organizações não governamentais feministas têm um papel muito importante no que Nancy Fraser chama de contra-públicos subalternos, que constituem contradiscursos ou arenas discursivas paralelas, nas quais os grupos marginalizados podem encontrar voz e formular interpretações opostas às dominantes sobre seus interesses, identidades e necessidades ${ }^{7}$.

${ }^{7}$ Nancy Fraser, "Rethinking the Public Sphere: A Contribution to the Critique of Actually Existing 
A política de cotas como forma de garantir os direitos das mulheres é vista como problemática por alguns, pois as mulheres não têm todas os mesmos interesses e ocupam, ao mesmo tempo, diferentes posições de sujeito na sociedade, sofrendo, por isso, pressões variadas e, por vezes, contraditórias. De fato, as mulheres não possuem interesses idênticos apenas por serem mulheres, mas possuem direitos fundamentais reconhecidos por organizações internacionais que devem ser garantidos e protegidos. Direitos fundamentais não são negociáveis e é por isso que são contra-majoritários. A defesa desses direitos não deveria depender da presença de mulheres na esfera política, pois são direitos humanos, mas a representação é sim importante e mulheres empoderadas e conscientes são as melhores advogadas de outras mulheres.

Assim, é importante buscar eleger representantes femininas que estejam atentas às questões de opressão e de desigualdade que afligem as mulheres e que sejam conscientes dos direitos que devem ser protegidos. Além disso, é preciso apostar na formação política a partir da base, com educação de gênero nas escolas e o incentivo à participação de mulheres em organizações não governamentais e outros movimentos da sociedade civil.

Existem tentativas, tanto do governo federal, como dos governos estaduais, de implantação de políticas de educação de gênero nas salas de aula, mas elas são veementemente rechaçadas pelos setores conservadores da política e da sociedade. Para a UNESCO (Organização das Nações Unidas para a Educação, a Ciência e a Cultura), a igualdade de gênero é uma prioridade global e está ligada intrinsicamente aos esforços para promover a educação. Segundo a organização, a discriminação de gênero na educação é, ao mesmo tempo, causa e consequência de outras formas de desigualdade de gênero na sociedade.

As políticas de ação afirmativa não devem ser entendidas como desimportantes, pois são uma tentativa de resposta às desigualdades sociais que contaminam o espaço público. O que deve-se ter em conta é que as cotas não têm capacidade para resolverem, sozinhas, os problemas de desigualdade de gênero. A conscientização

Democracy", in Habermas and the Public Sphere, org. Craig Calhoun (Cambridge, MA: MIT Press, 1992), 123. 
sobre os direitos das mulheres deve ser expandida para outros espaços da sociedade democrática. É necessário democratizar a democracia para que a igualdade material de gênero seja 


\section{Breves considerações sobre os critérios jurídicos de realização da despesa pública}

\section{Hugo Flores da Silva*}

RESUMO: A despesa pública e o respetivo controlo é um dos domínios onde a tensão entre as dimensões económicas e mercantis, por um lado, e juridicas e sociais, por outro, mais se faz notar. Cabe perguntar, quando se realiza e controla uma despesa pública, o que é mais importante: que a despesa pública seja económica, eficaz e eficiente, ou seja legal e justa? Ou ambas? Ou uma coisa pressupõe a outra?

PALAV RAS-CHAVE: despesa pública-economia-eficiência e eficácia.

ABSTR ACT: The public expenditure and its control is one domain in which the tension between economic and mercantile dimensions, on the one hand, and legal and social dimensions, on the other, is more strongly felt. When public expenditure is carried out, it is worth asking what is more important: if public expenditure is economic, efficient and effective or legal and fair? Or both? Or does one thing presupposes the other?

KEYWORDS: public expenditure - economic - efficiency and effectiveness.

* Docente e Doutorando em Ciências Jurídicas Públicas na Universidade do Minho (com bolsa FCT). Membro não Doutorado do Centro de Estudos em Direito da União Europeia - CEDU. 


\section{I.}

A prossecução do interesse público, concretizada numa atividade por via da qual é promovida a satisfação das necessidades coletivas, pressupõe que o Estado em si mesmo considerado, ou nos seus mais diversos desdobramentos - reúna um complexo de recursos financeiros e que efetivamente os afete a esse propósito. Neste contexto, articulam-se e complementam-se duas dimensões fundamentais, uma que respeita à arrecadação de recursos financeiros (receita pública) e outra que respeita à afetação dos recursos arrecadados (despesa pública). Sem prejuízo da interpenetração e necessária complementaridade das dimensões referidas, bem como da necessidade de perspetivar a atividade financeira pública na sua globalidade, considerando quer as receitas quer as despesas públicas ${ }^{1}$, a dimensão da despesa pública tende a ver o seu tratamento doutrinal negligenciado, quando comparado com o trabalho de investigação dedicado à componente da receita pública² .

Num contexto de escassez de recursos financeiros, a disciplina jurídica da despesa pública assume uma relevância tão ou mais preponderante que a disciplina da sua arrecadação. É certo que a componente da receita, comportando um complexo de atos destinados a produzir ablações patrimoniais na economia com vista a dela extrair recursos que serão destinados à satisfação das necessidades coletivas, se reveste de carater eminentemente restritivo, o que pressuporá um especial reforço do tratamento jurídico oferecido a estas matérias. Poderíamos, em contraposição, ser tentados a considerar que a realização da despesa pública, por se associar a uma atividade eminentemente prestadora, estaria dissociada desse carater restritivo, pelo que estariam dispensadas especiais preocupações de teorização jurídica neste domínio. Ficaria, por esta via, justificado o desequilíbrio que se verifica entre a atenção dada na doutrina a uma e outra matéria. No entanto, só aparentemente é possível afastar o caráter restritivo da realização da despesa pública. A despesa pública

\footnotetext{
${ }^{1}$ Cfr. Sofía Borgia Sorrosal, "Los principios constitucionales de eficiência y economia en la programación y ejecución de los gastos públicos" Presupuesto y Gasto Público 34 (2004): 42.

${ }^{2}$ Cfr. Benoît Chevauchez, "La dépense publique, au coeur de nos systèmes de finances publiques", Revue Française de Finances Publiques 77 (Mars, 2002): 27 e ss; e Sofía Borgia Sorrosal, Los principios constitucionales, 46.
} 
realizada repercute-se de forma direta e irremediável em termos quantitativos sobre o nível das necessidades financeiras, pelo que condiciona, ainda que indiretamente, o nível das referidas ablações patrimoniais produzidas na economia com vista a dela extrair recursos financeiros. Alias, num contexto de Estado fiscal, no âmbito do qual a obtenção de receitas é, essencialmente, levada a cabo por via da arrecadação de impostos, facilmente se concebe que o aumento da despesa pública - pelo menos em termos tendenciais - tem por consequência imediata o aumento, em termos quantitativos, do nível de impostos arrecadados ${ }^{3}$.

E se a rigorosa disciplina e controlo da realização da despesa pública é fundamental numa perspetiva nacional, também não poderá deixar de o ser numa ótica transestadual/supraestadual ou de integração, como a que se refere aos ordenamentos compostos, como o ordenamento da União Europeia. Excluindo da nossa análise as competências financeiras e orçamentais próprias da União, diremos, apenas, que aquela possui um complexo sistema financeiro que se reflete sobre a realidade financeira interna dos Estados-Nembros, como nomeadamente sucede ao nível do controlo dos défices excessivos (artigo 126. do TFUE), das normas que disciplinam o acesso aos fundos de Direito da União Europeia, as quais impõe aos Estados-Membros uma disciplina jurídica, financeira e orçamental própria, como forma de garantir a eficácia das políticas que se encontram subjacentes à atribuição dos mesmos ${ }^{4}$, ou das normas que disciplinam dos procedimentos a adotar aquando da realização de despesa de base contratual - isto é, da contratação pública ${ }^{5}$.

No presente texto - o qual corresponde, no essencial, à nossa exposição no âmbito do workshop que dá origem a este e-book - tecemos algumas considerações sobre os critérios que disciplinam a realização da "despesa pública", reconduzimos a este conceito qualquer ato jurídico-público que, no exercício de funções administrativas,

\footnotetext{
${ }^{3}$ Cfr. José Casalta Nabais, O Dever Fundamental de Pagar Impostos, Contributo para a compreensão constitucional do estado fiscal contemporâneo (Coimbra: Almedina, 1988), 210 e ss.

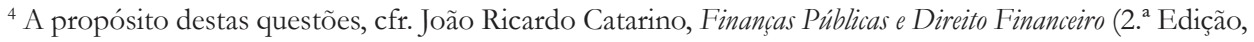
Coimbra: Almedina, 2014), 185 e ss.

${ }^{5}$ Sobre a questão, cfr. Hugo Flores da Silva, "Novas Diretivas e tópicos de despesa pública" Revista dos Contratos Públicos 11 (2016): 69 e ss.
} 
comporte uma afetação de recursos financeiros públicos - isto é, de bens (moveis ou imóveis) com expressão económica (portanto, suscetíveis de avaliação pecuniária) que integrem a esfera patrimonial das entidades jurídico-públicas ${ }^{6}$.

\section{II.}

Os critérios tradicionalmente associados à realização da "despesa pública" dizem respeito à verificação da sua conformidade legalidade e regularidade formais ${ }^{7}$. Importa, neste tipo de controlo, que os atos de gestão financeira sejam produzidos em estrita conformidade com as normas jurídicas em vigor, em termos tais que um bom ato de despesa será aquele que, em termos eminentemente formais, obedeça à disciplina normativa aplicável, mormente ao procedimento preestabelecido para esse efeito $^{8}$. Trata-se, no essencial, da convocação para o domínio do Direito financeiro do princípio da legalidade, exigindo-se que qualquer ato de realização de despesa pública tenha respaldo e se encontre em conformidade com a lei - amplamente concebida, no sentido da exigência de conformidade jurídica dos referidos atos. Em consequência, o controlo exercido sobre os referidos atos poderia limitar-se a aferir se os mesmos obedeciam às normas jurídicas em vigor, assumindo-se irrelevantes os resultados financeiros a que os mesmos conduzissem. Por exemplo, e a este respeito,

\footnotetext{
${ }^{6}$ Acompanhamos, no essencial, Freitas da Rocha, quando reconduz o conceito de despesa pública, em sentido jurídico, ao "ato jurídico-público de afetação de recursos financeiros à prossecução do Interesse público" - cfr. Joaquim Freitas da Rocha, Relatório sobre a unidade Curricular: Direito da despesa pública (disponibilizado pelo Autor).

${ }^{7}$ Entre outros, cfr. José F. F. Tavares, Estudos de Administração e Finanças Públicas (2. ${ }^{a}$ Edição Atualizada, Coimbra: Almedina, 2014), 171; Lia Olema F. V. J. Correia, “O Dever de Boa Gestão e a Responsabilidade Financeira", in Estudos Jurídicos e Económicos em Homenagem ao Prof. Doutor António de Sousa Franco (Vol. II, Coimbra: Coimbra Editora, 2006), 798; e Paulo Nogueira da Costa, O Tribunal de Contas e a Boa Governança, Contributo para uma Reforma do Controlo Financeiro Externo em Portugal (Coimbra: Coimbra Editora, 2014), 165-166.

${ }^{8} \mathrm{Na}$ nossa ordem jurídica, entre outras disposições, cfr. n. ${ }^{\circ} 2$ do artigo $266 .^{\circ}$ da Constituição da República Portuguesa (CRP), artigo 3. ${ }^{\circ}$ do Código de Procedimento Administrativo (CPA), al. a) do n. ${ }^{\circ}$ 3 do artigo 52. ${ }^{\circ}$ da Lei de Enquadramento Orçamental (LEO), Lei n. ${ }^{\circ}$ 151/2015, de 11 de setembro, e artigo 22. ${ }^{\circ}$ do Regime de Administração Financeira do Estado (RAFE), aprovado pelo Decreto-Lei n. ${ }^{\circ}$ 155/92, de 28 de julho.
} 
importará considerar se existe lei que autorize a despesa, se a mesma tem inscrição orçamental, esta cabimentada e adequadamente classificada.

A perceção de que a simples conformidade com a lei - aqui entendida em sentido amplo, integrando, nomeadamente, normas de Direito da União Europeia, Direito Internacional - e com o procedimento de realização da despesa seria insuficiente para garantir uma otimização da afetação dos recursos financeiros públicos deu lugar a uma reconfiguração do modelo de gestão financeira pública. Assim, para além da sua vinculação a critérios de legalidade formal e de regularidade, verificou-se uma evolução no sentido de se exigir que aquela atividade se conformasse com uma lógica de boa gestão. Importaria, neste sentido, garantir a racionalidade económica da despesa pública mediante a sujeição da sua realização a critérios de economia, eficiência e eficácia ${ }^{9}$. A boa gestão, que corresponde à transposição para o domínio económico do princípio constitucional da proporcionalidade, incorpora uma ideia de prudência nos gastos e apela à mais racional utilização possível dos recursos financeiros - desde logo, em atenção à necessidade de garantir a sustentabilidade das finanças públicas e, por maioria de razão, o cumprimento do princípio da equidade intergeracional ${ }^{10}$. Sem prejuízo da respetiva substância económica, trata-se de uma verdadeira imposição jurídica, procurando-se disciplinar no plano jurídico o mérito económico de um comportamento de gestão, mediante a imposição de deveres jurídicos de conduta no sentido de programar e desenvolver a gestão das atividades segundo critérios de racionalidade, maximizando a utilidade dos recursos disponíveis. Assim, a boa gestão da atividade financeira pública passa a ser aferida em atenção a três critérios essenciais: (i) a economia - exigência de que os recursos financeiros, humanos e materiais, tanto sob o ponto de vista da qualidade como da quantidade, sejam adquiridos no momento oportuno e pelo menor custo; (ii) a eficiência -

\footnotetext{
${ }^{9}$ Cfr. o artigo $22 .^{\circ}$ do RAFE e artigos $18 .^{\circ}$ e al. c) do n. ${ }^{\circ} 2$ do artigo $52 .{ }^{\circ}$ LEO.

${ }^{10}$ Sobre a temática, cfr. Joaquim Freitas da Rocha, "Sustentabilidade e Finanças Públicas Responsáveis, Urgência de Um Direito Financeiro Equigeracional”, in Estudos em Homenagem ao Prof. Doutor José Joaquim Gomes Canotilho, org. Fernando Alves Correia, Jónatas M. Machado e João Carlos Loureiro (Vol. I, Stvdia Ivridica - 102, Coimbra: Coimbra Editora, 2012), 612 e ss; Juan Martín Queralt et al., Curso de Derecho Financiero y Tributario (20. ed., Madrid: Tecnos, 2009), 116.
} 
exigência de que a utilização dos recursos financeiros seja levada a efeito de forma a obter a minimização do desperdício e o nível máximo de resultados possíveis, em termos qualitativos e quantitativos; e (iii) a eficácia - exigência de que a utilização dos recursos financeiros seja apta a produzir os objetivos que a determinaram ${ }^{11}$.

\section{III.}

A convocação da racionalidade económica como princípio disciplinador da atividade financeira pública procura garantir uma ótima afetação dos recursos públicos, mediante a obtenção dos resultados de gestão pretendidos com o menor nível de desperdício possível ${ }^{12}$. No entanto, a inegável preponderância da aplicação dos critérios de racionalidade económica à atividade financeira pública não pode ser assumida em termos absolutos e de modo a resultar no sacrifício dos demais valores juridicamente relevantes. Importa buscar um compromisso entre as exigências de boa gestão e de racionalidade económica - as quais no âmbito do Direito da União Europeia assumem uma relevância acrescida, em face da tendência para a funcionalização de soluções tendo em vista a necessidade de garantir o respeito pelas liberdades económicas fundamentais e pelos valores da concorrência - e as demais exigências que, no contexto de um Estado de Direito democrático, não poderão resultar sacrificadas, tais como os valores fundamentais da dignidade humana, da igualdade, da liberdade, da proteção do ambiente ${ }^{13}$.

\footnotetext{
${ }^{11}$ Sobre os aspetos em análise e, em geral, sobre os referidos critérios, cfr. Carlos Moreno, Finanças Públicas, Gestão e Controlo dos Dinbeiros Públicos (2. ${ }^{a}$ Edição Revista e Aumentada, Lisboa: Universidade Autónoma de Lisboa, 2000), 75 e ss; Lia Olema F. V. J. Correia, "O Dever de Boa Gestão", 791 e ss; Joaquim Freitas da Rocha, Direito Financeiro Local, 126 e ss; João Carlos Simões Gonçalves Loureiro, O Procedimento Administrativo entre a Eficiência e a Garantia dos Particulares (Algumas considerações) (Svdia Ivridica n. ${ }^{\circ}$ 13, Universidade de Coimbra: Coimbra Editora, 1995), 131-132. Numa perspetiva económica, cfr. Paul A. Samuelson e William D. Nordhaus, Economia (18. ${ }^{a}$ Edição, Tradução e Revisão Técnica Elsa Fontainha e Jorge Pires, Nova Iorque: McGraw-Hill, 2006), 4 e 738; e Francisco Mochón Morcillo e Roberto Luís Troster, Introdução à Economia (tradução e revisão técnica de Roberto Luís Troster, São Paulo: Makron Books, 1994), 86. Na jurisprudência, entre outros, cfr. Acórdão do Tribunal de Contas n..$^{\circ}$ 57/2011 - 11.Jul.2011 - 1'aS/SS, proferido no Processo n..$^{\circ}$ 364/2011.

${ }^{12}$ Cfr., Juan Martín Queralt et al., Curso de Derecho Financiero, 116.

${ }^{13}$ Cfr. Janet Denhardt e Robert Denhardt, The New Public Service: serving, not steering (Nova Iorque: M.E.
} 
Deverá ser assumida uma visão axiológica da atividade financeira pública, de modo a que resultem conciliados os interesses relacionados com a garantia da racionalidade económica dos atos de gestão pública e os que se associam ao respeito pelos valores constitucionais fundamentais. Em especial, no âmbito da União Europeia, deverá garantir-se a devida articulação entre duas dimensões axiológicas fundamentais: a dimensão económica, mercantil e concorrencial; e a dimensão "dignitária", social e redistributiva.

\section{IV.}

Tendo em consideração o exposto, o controlo financeiro exercido sobre a despesa pública deverá orientar-se no sentido da verificação do cumprimento dos referidos critérios disciplinadores da sua realização.

Tradicionalmente, a doutrina estabelecia uma distinção entre controlo de legalidade e da regularidade e o controlo do mérito da despesa pública. O controlo da regularidade e da legalidade financeira corresponderia à aferição da conformidade do ato controlado com o complexo de normas financeiras e contabilísticas aplicáveis. Por sua vez, o controlo do mérito corresponderia à verificação da conformidade do ato controlado com os critérios da economia, eficiência e eficácia, pelo ato controlado. A doutrina vem recusando a distinção estabelecida, com fundamento na sua falta de rigor, uma vez que, na medida em que se encontram positivados em normas jurídicas os critérios da economia, eficiência e eficácia, também decorrendo de princípios e valores constitucionalmente consagrados, deixa de ser possível conceber tal controlo com um controlo de mérito, mas sempre, e necessariamente, de legalidade.

Assumimos como válida a crítica assumida contra a referida categorização. No entanto, e sem prejuízo da necessidade de promovermos algumas precisões terminológicas, consideramos que poderá ser estabelecida uma distinção fundamental entre o controlo de legalidade e o controlo de mérito da decisão. Vejamos.

Sharp, Inc., 2007), 25 e ss; Carlos Moreno, Finanças Públicas, 77 e ss; Paulo Nogueira da Costa, O Tribunal de Contas e a Boa Governança, 194 e ss. 
O controlo da legalidade deverá ser concebido como a verificação da conformidade do ato de despesa controlado com o ordenamento jurídico amplamente considerado ${ }^{14}$ - nomeadamente, a conformidade dos atos de gestão financeira pública com os princípios e valores que enquadram tal atividade do ponto de vista jurídico-constitucional, como sejam os princípios da legalidade, da prossecução do interesse público, respeito pelos direitos e interesses legalmente protegidos, da justiça, da igualdade, da proporcionalidade, da boa-fé e da boagestão $^{15}$. Este exercício pressuporá o controlo da legalidade e da regularidade da despesa pública, portanto, da sua conformidade com as normas jurídicas financeiras e contabilísticas aplicáveis - que designaremos por controlo da legalidade formal -, como também pressupõe o controlo do cumprimento dos critérios de boa gestão (economia, eficiência e eficácia $)^{16}$, - que designaremos por controlo da legalidade material ${ }^{17}$. Trata-se, neste segundo caso, de controlar o mérito económico do ato de despesa sindicado, concebido como uma exigência legal - expressamente consagrada

\footnotetext{
${ }^{14}$ Por outro lado, afigurar-se-á problemática a questão de saber como deverá proceder o ente responsável pela realização da despesa pública nos casos em que se encontre vinculado a imperativos legais de sentido contrário. Pense-se, por exemplo, na hipótese de certo hospital se ver confrontado com a necessidade de adquirir determinado medicamento como condição de sobrevivência de determinado doente e, em simultâneo, com a impossibilidade de realizar despesa, por impossibilidade de cumprimento do disposto no n. 1 do artigo 5. ${ }^{\circ}$ na Lei dos Compromissos e dos Pagamentos em Atraso (LCPA), aprovada pela Lei n. ${ }^{\circ} 8 / 2012$, de 21 de fevereiro. A este respeito, guardamos algumas reservas relativamente àquela que tem sido a posição do Tribunal de Contas a respeito desta temática - a este respeito, cfr., nomeadamente, os Acórdãos n. ${ }^{\circ}$ s 3/2015 e 25/2014.

${ }^{15}$ Cfr. José F. F. Tavares, “A Ponderação de Interesses na Gestão Pública Vs. Gestão Privada”, in Estudos Jurídicos e Económicos em Homenagem ao Prof. Doutor António de Sousa Franco (Vol. II, Coimbra: Coimbra Editora, 2006), 668.

${ }^{16} \mathrm{O}$ exercício do referido controlo recebe previsão expressa na ordem jurídica interna - cfr. artigo 1. ${ }^{\circ}$, al. f) do n. ${ }^{\circ} 1$ do artigo $5 .^{\circ}$, als. f) e h) do.$^{\circ} 3$ do artigo $54 .^{\circ}$ e no n. ${ }^{\circ} 1$ do artigo $50 .^{\circ}$, todos da Lei de Organização e Processo do Tribunal de Contas (doravante, LOPTC). No Direito da União Europeia, cfr. n. ${ }^{\circ} 2$ do artigo $287 .^{\circ}$ do Tratado sobre o Funcionamento da União Europeia (doravante, TFUE), a respeito das competências do Tribunal de Contas da União Europeia.

${ }^{17}$ Cfr. José F. F. Tavares, "Sistema nacional de controlo: controlo interno e controlo externo", Revista do Tribunal de Contas 26 (1996); Lia Olema F. V. J. Correia, "O Dever de Boa Gestão”, 795; Francesc Boshc Ferré, "La función de control financiero en la administración local: Del control de legalidad y contable al control de lagestión económica" Revista de Hacienda Local 30,90 (Set-Dez, 2000); e J. Beckers, "O Controlo da Eficácia por Tribunais de Contas" Revista do Tribunal de Contas 28 (Jul-Dez, 1997): 85 e ss. Na jurisprudência, sobre a aplicabilidade dos referidos critérios, entre outros, cfr. Acórdãos do Tribunal de Contas, n. ${ }^{\circ}$ 15/2014, 24/2012, 282/2012; e 69/2011.
} 
em lei ordinária, mas que, sem prejuízo dessa previsão, decorre de princípios jurídicos constitucionalmente consagrados -, o que significa que não estamos perante um controlo da conveniência ou oportunidade do ato, mas, em sentido diametralmente oposto, perante um controlo de legalidade ${ }^{18}$. Significa isto que uma decisão que não respeite os referidos critérios de economia, eficiência, e eficácia será uma decisão ilegal. Entre uma solução que cumpra superiormente aqueles critérios, e uma outra que não os cumpra de forma tão satisfatória, o decisor público não se encontrará legitimado a optar, alternativamente, por uma ou por outra.

Não ignoramos as dificuldades materiais que se possam levantar neste domínio, nomeadamente quando a aplicação dos supramencionados critérios no caso concreto implique, por exemplo, o controlo da eficácia social de uma política redistributiva ou de uma política regional europeia de redução das assimetrias. No entanto, da referida dificuldade não poderá ser extraída uma requalificação da natureza jurídica de tais critérios. Se o decisor público se encontra legalmente vinculado a decidir em termos económicos, eficientes e eficazes, uma decisão que não cumpra tais exigências, atenta a sua desconformidade com as normas jurídicas que as estabelecem, será uma decisão ilegal, de onde poderá extrair-se a respetiva invalidade ${ }^{19}$ e ineficácia ${ }^{20}$.

Uma vez "juridificados", os referidos critérios de racionalidade económica não se movimentam no contexto do controlo do exercício de poderes discricionários, antes têm por função a delimitação de momentos/fronteiras de vinculação no âmbito do

\footnotetext{
${ }^{18}$ No sentido de que a legalidade substantiva da gestão de bens públicos só é apreciável mediante o recurso a critérios técnicos de avaliação do mérito financeiro, cfr. Lia Olema F. V. J. Correia, "O Dever de Boa Gestão", 795.

${ }^{19}$ Sobre o regime das invalidades, entre outros, cfr. Mário Aroso de Almeida, Teoria Geral do Direito Administrativo, O Novo Regime do Código do Procedimento Administrativo (Coimbra: Almedina, 2016), 255 e ss; Licínio Martins Lopes, "A invalidade do acto administrativo no Novo Código do Procedimento Administrativo: as alterações mais relevantes", in Comentários ao Novo Código do Procedimento Administrativo, coord. Carla Amado Gomes, Ana Fernanda Neves w Tiago Serrão (Vol. II, Lisboa: AAFDL, 2016), 286 e ss., e Fabrizio di Luciani, "L'invalidità e le altre anomalie dell'atto amministrativo: inquadramento teórico" in L'invalidità Amministrativa, a cura di Vicenzo Verulli Irelli, Luca de Lucia (Torino: G. Giappichelli Editore, 2009): 4 e ss.

${ }^{20}$ Nos termos da al. c) do n. ${ }^{\circ} 1$ do artigo 5. ${ }^{\circ}$ e artigos 44. ${ }^{\circ}$ e seguintes da Lei de Organização e Processo do Tribunal de Contas (LOPTC) os atos geradores de despesa pública encontrar-se-ão sujeitos a um controlo de eficácia, exercido no âmbito dos poderes de fiscalização prévia do Tribunal de Contas.
} 
exercício de tais poderes - ou seja, a discricionariedade administrativa é negativamente delimitada pelos critérios da economia, eficiência e eficácia da despesa.

Coloca-se portanto, a questão de saber se, permanece válida de conteúdo a distinção entre controlo de legalidade e controlo de mérito. Consideramos que sim. Quando o decisor público se encontre perante duas, ou mais, soluções que cumpram de igual forma os critérios da economia, eficiência e eficácia, estará legitimado a optar alternativamente entre as mesmas, sem que, porém, essa decisão possa ser objeto de um juízo de censura do ponto de vista legal. Entramos aqui no domínio da oportunidade e conveniência da decisão de realização da despesa pública, pelo que, por maioria de razão, o controlo exercido estará limitado a um controlo de mérito ${ }^{21}$. A apreciação do mérito permitirá a distinção entre boas e más decisões, mas umas e outras serão decisões legais, o que fundamentará a respetiva insindicabildidade do ponto de vista jurisdicional. Aliás, face ao já mencionado quadro jurídico-constitucional enformador da atividade de gestão dos recursos financeiros públicos, a margem de discricionariedade conferida aos gestores públicos é, no nosso ordenamento jurídico, relativamente reduzida ${ }^{22}$.

Este juízo, que em termos teórico-abstratos se apresenta bastante linear, em concreto poderá assumir contornos extremamente complexos. Assim, porque uma decisão mais eficiente poderá não corresponder a uma decisão mais eficaz, como o inverso também é verdadeiro. A eficiência reconduzir-se-á a uma lógica de redução ou minimização da utilização dos recursos necessários para produzir um determinado nível de resultados; ou, em sentido diverso, ao aumento do volume de resultados obtidos para um determinado nível de recursos. Neste sentido, o incremento dos níveis de eficiência poderá ocorrer: por via de um decréscimo do nível de recursos utilizados, caso em que deverá ser acompanhado pelo incremento, manutenção, ou redução menos que proporcional, dos níveis de resultados obtidos; como poderá ocorrer por via de um incremento do nível de recursos utilizados, desde que o

\footnotetext{
${ }^{21} \mathrm{Na}$ jurisprudência, sobre o controlo dos atos discricionários, cfr. Acórdão do STA de 03.03.2016, proferido no âmbito do Processo n. ${ }^{\circ}$ 0768/15.

${ }^{22}$ Neste sentido, cfr. Lia Olema F. V. J. Correia, "O Dever de Boa Gestão”, 795.
} 
mesmo seja acompanhado por um incremento mais do que proporcional dos níveis de resultados obtidos. Desta forma, o decisor público pode ser colocado perante a necessidade de escolher entre soluções igualmente eficientes - porque compreendem uma distinta distribuição entre as componentes dos custos e dos resultados -, mas que apresentam níveis de eficácia distintos. Por outro lado, poderá suceder que a obtenção de determinado nível de resultados (portanto, de eficácia) pressuponha a adoção de uma solução menos eficiente que outras que se colocam em alternativa. Tais situações deverão, quanto a nós, ser resolvidas com recurso a uma ponderação dos interesses públicos em presença: o específico interesse público que se pretende prosseguir com o concreto ato de despesa em causa; e o interesse público associado à eficiente afetação dos recursos financeiros públicos. Esta ponderação deverá passar pela definição do nível mínimo de resultados que ainda se possa considerar compatível com o interesse público prosseguido com o ato de despesa a realizar, de modo a que a busca da solução mais eficiente não possa determinar o sacrifício intolerável desse interesse - solução, aliás, conforme com a lógica de proporcionalidade que referimos ser inerente à consagração dos critérios de boa gestão ${ }^{23}$. Neste domínio, serão (naturalmente) acrescidas as exigências de fundamentação dos atos - de facto, o dever de fundamentação tem consagração constitucional expressa no artigo 268. ' da Constituição da República Portuguesa (CRP), e no domínio da atividade financeira pública traduz-se num especial dever de prestação de $\operatorname{contas}^{24}$. Poderá, inclusivamente, suceder que, em virtude da natureza do específico interesse público subjacente à realização do ato de despesa em causa, a componente da eficácia não possa ser assumida em termos variáveis. Nestes casos, deverá ser adotada a solução mais eficiente, portanto, a que, garantindo os resultados pretendidos, pressupõe uma menor afetação de recursos.

Para além das formas de controlo que acabamos de expor, a doutrina tem avançando a importância da avaliação da gestão financeira, entendida como uma

\footnotetext{
${ }^{23}$ Sobre a questão, cfr. Carlos Moreno, Finanças Públicas, 77.

${ }^{24}$ Sobre o dever de prestação de contas, cfr. Joaquim Freitas da Rocha e Hugo Flores da Silva, "Os deveres de prestação de contas por parte dos entes locais", in Anuário Publicista da Escola de Direito da Universidade do Minho (Tomo III., Braga: Escola de Direito da Universidade do Minho, 2015, no prelo).
} 
atividade técnico-científica que, podendo incidir sobre a pode incidir sobre a respetiva pertinência e oportunidade, não se limita à análise e apreciação dos objetivos fixados com os recursos financeiros aplicados para o efeito, mas que tem, ainda, por referência os respetivos efeitos (diretos e indiretos), o que permite a consideração neste domínio dos efeitos sociais e ambientais que se lhe associam ${ }^{25}$. Trata-se de uma forma de controlo que, socorrendo-se dos métodos de investigação e técnicas das ciências sociais, tais como inquéritos estatísticos, estudos económicos, sociológicos, ambientais, etc., assume como propósito essencial o de apreender a utilidade social dos gastos públicos, apurando os impactos da despesa pública na qualidade de vida das pessoas.

\section{V.}

Em face do que vimos de expor, e em jeito de conclusão, podemos dizer o seguinte:

i. A atividade desenvolvida pelo Estado - amplamente concebido - com o propósito de ver prosseguidas as suas atribuições - em termos gerais, a prossecução do Interesse Público - traduz-se em inevitáveis onerações da esfera jurídica fundamental dos privados, na medida em que é junto destes que são arrecadados os recursos financeiros que constituem pressuposto de tal atividade;

ii. Em consequência, os recursos utilizados deverão corresponder aos indispensáveis para a garantir o nível de resultados pretendidos, evitando-se desperdícios injustificados;

iii. Procurando garantir o referido propósito, o legislador exige que despesa pública obedeça aos critérios seguintes: (i) a conformidade legal; (ii) a regularidade financeira; e (iii) a economia, eficiência e eficácia;

iv. A verificação do cumprimento dos referidos critérios constitui um

\footnotetext{
${ }^{25}$ Sobre o conceito, métodos e objetivos da avaliação, cfr. José F. F. Tavares, Estudos de Administração e Finanças Públicas, 172-173; e Carlos Moreno, Finanças Públicas, 78.
} 
controlo de legalidade - a confrontação dos atos de despesa com os critérios de economia, eficiência e eficácia corresponde, ainda, a um controlo de legalidade, porquanto os mesmos têm por finalidade delimitar negativamente os âmbito do exercício dos poderes discricionários;

v. $\mathrm{O}$ que se refere não exclui, no entanto, a existência de poderes discricionários neste contexto, os quais emergirão nos casos em que o legislador conceda à administração uma margem de conformação da aplicação da lei no caso concreto, e se verifique a existência de várias soluções compatíveis com os supramencionados critérios de legalidade material - em tais casos, a atuação administrativa apenas poderá resultar sujeita a um controlo de mérito. 



\title{
Organizações Sociais e Organizações da Sociedade Civil de Interesse Público como prestadoras de serviços públicos não exclusivos: reflexões em termos de controle e de abertura às práticas corruptivas a partir da interpretação constitucional dada à Lei 9.637/1998
}

\author{
Janriê Rodrigues Reck*/Ana Helena Scalco Corazza**
}

RESUMO: Os processos de (des)publicização do Estado, iniciados a partir da reforma gerencial da administração pública na década de 90 no Brasil, revelaram a transferência do gerenciamento e da execução de serviços públicos não exclusivos para Organizações Sociais e Organizações da Sociedade Civil de Interesse Público (OS e OSCIPs), entidades de direito privado sem fins lucrativos. O Supremo Tribunal Federal manifestou-se acerca da matéria, ao apreciar a constitucionalidade da Lei n. ${ }^{\circ}$ 9.637/1998, através do julgamento da Ação Direta de Inconstitucionalidade ${ }^{\circ}{ }^{\circ} 1923$, conferindo à norma uma interpretação que ratifica a adoção desse modelo de gestão pelo Estado brasileiro. Entretanto, a decisão exarada constituiu-se de uma linguagem demasiado vaga, notadamente ao referenciar princípios e prescindir de institutos jurídicos próprios da administração pública, como a licitação e o concurso público. Destarte, este ensaio visa à demonstração do elo existente entre a interpretação constitucional conferida à Lei 9.637/ 1998 e a amplitude de um ambiente pouco propício ao controle da administração pública e ao combate à fraude e corrupşão.

PALAV RAS-CHAVE: corrupção - Organizações Sociais - Organizações da Sociedade Civil de Interesse Público reforma do Estado - Tribunais de Contas.

ABSTR ACT: Processes of the State depublicisation started with the 1990s Brazilian public management reform have showed the shift of the non-exclusive public service management and performance for Social Organisations and Public Interest NonGovernmental Organisations, private non-profit entities. The Supreme Court Justice examined the Act no. 9637/1998 by judging the Direct Action of Unconstitutionality no. 1923, which gave the norm an interpretation ratifying the Brazilian State's use of this standard of management. However, the decision is presented in a too vague language, especially when referring to principles and dispensing with judicial instruments proper to the public administration, such as public tender and public bidding. Thus, this paper aims to show the link between the constitutional interpretation for the Act no. 9637/1998 and the range of an environment proper to control the public administration and combat fraud and corruption.

KEYWORDS: corruption - Social organisations - Public Interest Non-Governmental Organisations - State reform Court of auditors.

\footnotetext{
* Doutor pela Universidade do Vale do Rio dos Sinos - UNISINOS. Professor no Programa de PósGraduação em Direito da Universidade de Santa Cruz do Sul - UNISC.

** Mestranda em Direito na Universidade de Santa Cruz do Sul - UNISC.
} 


\section{Considerações iniciais}

As Organizações Sociais (OS) e as Organizações da Sociedade Civil de Interesse Público (OSCIPs) foram institucionalizadas e normatizadas pelas Leis Federais n. ${ }^{\circ} 9.637 / 1998^{1}$ e $9.790 / 1999^{2}$, respectivamente, visando atender ao comando de publicização do Estado, nos moldes propagados pela reforma gerencial iniciada no Brasil em 1995. Os discursos que gestaram a adoção desse modelo apregoaram uma maior flexibilidade e eficiência na prestação dos serviços públicos, a partir da retórica de ineficiência e ineficácia do modelo de administração pública burocrática.

Nessa linha, as parcerias do Estado com OS e OSCIPs, viabilizadas juridicamente por meio de Contratos de Gestão ou Termos de Parceria, a depender da qualificação recebida pela entidade, viabilizam o repasse de recursos públicos para o financiamento da execução dos objetivos avençados, serviços públicos não exclusivos, assumindo tais organizações não governamentais o compromisso de alcance de metas e resultados.

Atualmente, a transferência do gerenciamento e da execução de serviços públicos, como saúde e educação, por exemplo, a OS e OSCIPs é uma realidade corriqueiramente posta no Brasil, ainda que a o Supremo Tribunal Federal-STF tenha se pronunciado em definitivo sobre a matéria somente em abril de 2015. A atuação interpretativa do STF foi requerida por meio da interposição da Ação Direta de Inconstitucionalidade n. ${ }^{\circ} 1923$ que questionou a constitucionalidade da Lei n. ${ }^{\circ}$ 9.637 de 1998 - diploma legal que inseriu as OS no cenário administrativo brasileiro e instituiu o Programa Nacional de Publicização - e que será pormenorizadamente analisada nesse ensaio a fim de relacioná-la à atuação do controle externo e ao fenômeno das patologias corruptivas.

\footnotetext{
${ }^{1}$ Cfr. Lei 9.637 de 23 de março de 1998. Dispõe sobre a qualificação de entidades como organizações sociais, a criação do Programa Nacional de Publicização, a extinção dos órgãos e entidades que menciona e a absorção de suas atividades por organizações sociais, e dá outras providências. Publicado no Diário Oficial da União (DOU) de 18.5.1998.

${ }^{2}$ Cfr. Lei 9.790 de 23 de março de 1999, que dispõe sobre a qualificação de pessoas jurídicas de direito privado, sem fins lucrativos, como Organizações da Sociedade Civil de Interesse Público, institui e disciplina o Termo de Parceria, e outras providências. Publicado no DOU de 24.3.1999.
} 


\section{Instituições privadas atuando na prestação de serviços públicos e a atuação dos Tribunais de Contas}

Passados mais de 20 anos da instituição das reformas gerenciais no Brasil, OS e OSCIPS (além de muitas outras organizações não governamentais-ONGs) atuam nas mais diversas frentes de prestação de serviços públicos no país. De início, na reforma idealizada pelo então Ministro da Administração Federal e Reforma do Estado (Mare), Luiz Carlos Bresser Pereira, no primeiro governo do presidente Fernando Henrique Cardoso, o modelo das organizações sociais foi esboçado no projeto “Organização Social e Publicização" integrante do Plano Diretor de Reforma do Aparelho do Estado ${ }^{3}$. Em 1997, o Presidente da República promulgou o primeiro marco legislativo do modelo gerencial, a Medida Provisória n. ${ }^{\circ} 1.591$, convertida em maio de 1998, na Lei n. ${ }^{\circ}$ 9.637, a alcunhada "Lei das OS". Tal regramento estipulou os requisitos para a qualificação de entidades privadas sem fins lucrativos como organizações sociais e lançou o Programa Nacional de Publicização que previu o alargamento do modelo das OS por todo o país.

As OSCIPs, instituídas em âmbito federal pela Lei n. ${ }^{\circ}$ 9.790/1999, assim como as OS, nasceram sob a narrativa de modernização do Estado própria das reformas gerenciais de 1995. Fontoura (2010) descreve que a constituição das OSCIPs remota ao Programa Comunidade Solidária, criado pela antropóloga e então primeira-dama Ruth Cardoso, sob o arcabouço conceitual da Nova Gestão Pública. Tais entidades, à semelhança das $\mathrm{OS}^{4}$, não têm finalidade lucrativa e são instituídas com o objetivo de promover serviços de interesse coletivo, sendo a qualificação também uma condição para a celebração do ajuste de fomento (termo de parceria) vinculado ao alcance de resultados, ou seja, "por ter o seu caráter público

\footnotetext{
3 "Informações pormenorizadas acerca da Reforma Gerencial de 1995", acessadas em Fevereiro 12, 2017, http://www.bresserpereira.org.br/RGP.asp.

${ }^{4}$ As OS, em geral comportam estruturas administrativas maiores e se envolvem em operações que carecem de prazos e planejamentos mais longos. Já as OSCIPs tendem a ter estrutura física e de pessoal mais enxuta e se comprometem com metas e projetos pontuais da administração pública a que se vinculam.
} 
reconbecido, uma Oscip tem acesso mais fácil e menos burocrático a recursos públicos para a realização de projetos" 5 .

Com efeito, a delimitação entre esfera pública e privada, para Gabardo ${ }^{6}$, é decorrência típica da modernidade pós-absolutista (esta excluindo a competência política formal e jurídica da sociedade civil), delimitação que seguiu rumo ao século $\mathrm{XX}$, período este no qual a expressão "sociedade civil" foi utilizada para designar algo oposto ao Estado. Nessa linha, a expressão "sociedade civil", no Brasil da década de 70, passou a ser disseminada em um contexto de contraposição à ditadura militar, de forma que o Estado passou a representar tudo aquilo que era negativo (imagem do mal) e a sociedade civil lembrava à população tudo o que era positivo (imagem do bem $)^{7}$. Dado esse contexto, na década seguinte a ideologia neoliberal se apropria da mentalidade de que o Estado é fonte de mazelas (ainda que se esteja a falar de um Estado Democrático de Direito), tendo a mídia favorecido a disseminação de uma apologia à sociedade civil despolitizada, configurada em um terceiro setor falsamente situado além de Estado e mercado.

Ocorre que ainda em 1998 a agenda de disseminação do modelo das organizações sociais foi alvo de oposição por uma minoria governista à época, que propôs uma ADIn em face da Lei n. ${ }^{\circ} 9.637$ e do inciso XXIV, do artigo 24, da Lei n. ${ }^{\circ}$ 8.666/1993 (Lei de Licitações), com redação dada pela Lei n. ${ }^{0}$ 9.648/98, sob a justificativa de que a vigência desses dispositivos traria prejuízos ao erário e danos irreparáveis à população e aos servidores públicos. Houve o pedido de medida cautelar, a qual foi indeferida integralmente, por decisão majoritária, em agosto de 2007, sendo o julgamento de mérito concluso apenas em 2015.

Registra-se que desde a sua instituição, o programa de publicização foi alvo de inúmeras controvérsias ideológicas, jurídicas e mesmo técnicas - destacando-se

\footnotetext{
${ }^{5}$ Leandro Heitich Fontoura, "A influência de atores não estatais na formulação da lei das OSCIPS no Rio Grande do Sul: um estudo a partir da teoria das redes de politicas públicas" (Master's diss., Pontifícia Universidade Católica do Rio Grande do Sul, 2010), 55.

${ }^{6}$ Emerson Gabardo, "O Jardim e a Praça para além do Bem e do Mal - uma antítese ao critério de subsidiariedade como determinante dos fins do Estado social”, (PhD diss., Programa de Pós-Graduação em Direito do Estado Universidade Federal do Paraná, 2009), 49.

${ }^{7}$ Gabardo, "O Jardim e a Praça para além do Bem e do Mal”, 53.
} 
as polêmicas em torno da natureza jurídica do contrato de gestão e dos termos de parceria (contrato versus convênio), a eventual terceirização de atividade finalística, a discricionariedade na qualificação e seleção das entidades, além das interpretações divergentes acerca da necessidade de concurso público para o provimento de pessoal e de certame licitatório para a captação das entidades e também para as aquisições de bens e serviços ao longo da execução contratual junto a terceiros.

Quanto ao controle sobre tais parcerias, registra-se que os discursos que fundamentam a atuação fiscalizatória dos Tribunais de Contas sobre as organizações não estatais decorrem da própria Constituição Federal, já que o parágrafo único do artigo 70 dispõe que: "Prestará contas qualquer pessoa física on jurídica, pública ou privada, que utilize, arrecade, guarde, gerencie ou administre dinheiros, bens e valores públicos on pelos quais a União responda, ou que, em nome desta, assuma obrigações de natureza pecuniária". Dessa forma, a competência dos Tribunais de Contas para fiscalizar esses ajustes se fundamenta no fato de tais entidades privadas gerenciarem e alocarem recursos públicos, recursos esses sem os quais, muitas vezes, tais entidades sequer subsistiriam.

Por força do julgamento da ADIn 1923, que afastou qualquer restrição ao controle exercido pelas Cortes de Contas sobre ajustes com OS, a fiscalização exercida pelos Tribunais de Contas nesses casos, em regra, não questiona a constitucionalidade do modelo disseminado pela Lei n. ${ }^{\text {9 } 9.637 / 1998 . ~ D e s s a ~ f o r m a, ~ o s ~ o ́ r g a ̃ o s ~ d e ~ c o n t r o l e ~ c e n t r a m-s e, ~}$ normalmente, em um controle finalístico (de resultados) e de meios (legalidade), atuando com vistas a resguardar a minimização de fraudes e desvios de recursos.

Assim, em face do precário ambiente de controle da administração pública sobre tais vínculos - controle este que não se pode prescindir, ressalta-se, já que os ganhos de flexibilidade, economia e eficiência a partir do modelo proposto não são presumíveis, como sustentava a retórica modernizante -, qualquer tentativa de minimizar a atuação dos Tribunais de Contas nesse cenário parece ser temerária. A isso se alia a histórica cultura de abusos no trato do erário no Brasil e, notadamente, a ampliação de possibilidades de uma atuação arbitraria que a agenda de descentralização administrativa revelou.

\footnotetext{
${ }^{8}$ Constituição da República Federativa do Brasil. (Brasília: DF: Senado Federal, 1988).
} 


\section{Discricionariedade administrativa e a ADIn 1923}

Conforme exposto, a legislação inaugural do modelo da OS foi objeto de controle concentrado de constitucionalidade, por meio da Ação Direta de Inconstitucionalidade ainda em 19989 , quando da edição da Lei n. ${ }^{\circ}$ 9.637/1998. A apreciação da matéria teve termo apenas em 16 de abril de 2015, tendo o STF enfrentado a validade da norma considerada em abstrato mediante um discurso de justificação, e controvérsias acerca da aplicação da norma ao caso concreto (hipotético ou não $)^{10}$. Sinaliza-se que o interregno entre a propositura da ADIn e seu julgamento final, contemplou uma franca expansão das práticas de financiamento público de entidades não governamentais, como OS e OSCIPs, em todas as esferas de governo.

A conclusão levada a efeito pelo STF determinou que a celebração dos "convênios" (natureza jurídica dos contratos de gestão, à luz da Corte), seja conduzida de forma pública, objetiva e impessoal "em observância aos princípios constitucionais que regem a Administração Pública"11. Alguns dos Votos dos Ministros fizeram franca menção à retórica do engessamento estatal e da necessidade de uma gestão pública ágil e flexível, como o Voto-Vista do Ministro Gilmar Mendes ${ }^{12}$. Com o fim de analisar a linguagem que constituiu o posicionamento da Corte judicial acerca da matéria, cumpre a análise de excerto da parte dispositiva do referido Acórdão ${ }^{13}$.

\footnotetext{
9 Supremo Tribunal Federal. Ação Direta de Inconstitucionalidade 1.923 Distrito Federal, em 16/04/2015. Acessado em 15 de Outubro de 2016, http://redir.stf.jus.br/paginadorpub/paginador. jsp?docTP=TP\&docID=10 006961 .

${ }^{10}$ Almiro Eduardo de Almeida e Janriê Rodrigues Reck, Direito \& Ação Comunicativa: Apresentação e fundamentação teórica da matriz linguístico-pragmática de Jürgen Habermas e suas repercussões na compreensão do Direito, (Porto Alegre: HS Editora, 2013), 115.

${ }_{11}$ Supremo Tribunal Federal. Ação Direta de Inconstitucionalidade 1.923 Distrito Federal, em $16 / 04 / 2015$.

${ }^{12}$ Cfr. Lei 9.637/98: Organizações Sociais - 5, "O Min. Gilmar Mendes, em voto-vista, nesta assentada, também indeferindo a liminar, asseverou que a Lei 9.637/98 institui um programa de publicização de atividades e serviços não exclusivos do Estado, transferindo-os para a gestão desburocratizada a cargo de entidades de caráter privado e, portanto, submetendo-os a um regime mais flexivel, dinâmico e eficiente". acessado em Fevereiro, 2017, http://www.stf.jus. $\mathrm{br} /$ arquivo/informativo/documento/informativo474.htm.

13 “[... 20. Ação direta de inconstitucionalidade cujo pedido é julgado parcialmente procedente, para conferir interpretação conforme à Constituição à Lei n. ${ }^{\circ} 9.637 / 98$ e ao art. 24, XXIV, da Lei n. ${ }^{\circ}$ 8666/93, incluído pela Lei n. ${ }^{\circ}$ 9.648/98, para que: (i) o procedimento de qualificação seja conduz̨ido de forma pública, objetiva e impessoal,
} 
Assim, por votação majoritária, o Pretório Excelso julgou parcialmente procedente a ADIn 1923, dando interpretação conforme à Constituição aos diplomas legais impugnados, dentre os quais, as normas que dispensam licitação na celebração de contratos de gestão entre o Estado e as OS. Entretanto, ainda que assente pela Corte o posicionamento de que recursos públicos destinados a entidades qualificadas, os sejam por intermédio de procedimentos objetivos, públicos e impessoais, deixou o STF de caracterizar o que tais expressões significariam em termos práticos.

Veja-se que a utilização de termos vagos e lacunosos, como os referenciados no Acórdão, permite ver reconhecido nesse julgamento um discurso dotado de imprecisão denotativa, "com a aparência de descrever uma conduta, mas absolutamente vago em informações para ação" ${ }^{14}$. Por isso, os contornos práticos decorrentes da utilização de termos linguísticos anfibiológicos em uma decisão paradigma e vinculante para a administração pública pode resultar no incremento descompassado da discricionariedade daquele que opera recursos públicos (seja público ou privado) e, ao cabo, na abertura à arbitrariedade por parte deste.

Afigura-se igualmente como elemento favorável aos excessos de discricionariedade administrativa o fato de no decisum ter sido contemplado a dispensa de licitação para a celebração de contrato de gestão com OS qualificadas ${ }^{15}$, bem

com observância dos princípios do caput do art. 37 da CF, e de acordo com parâmetros fixados em abstrato segundo o que prega o art. 20 da Lei n. ${ }^{\circ}$ 9.637/98; (ii) a celebração do contrato de gestão seja conduðida de forma pública, objetiva e impessoal, com observância dos princípios do caput do art. 37 da CF; (iii) as hipóteses de dispensa de licitação para contratações (Lei n. ${ }^{\circ}$ 8.666/93, art. 24, XXIV) e outorga de permissão de uso de bem público (Lei n. ${ }^{\circ} 9.637 / 98$, art. $12, \S 3^{\circ}$ ) sejam conduzidas de forma pública, objetiva e impessoal, com observância dos princípios do caput do art. 37 da CF; (iv) os contratos a serem celebrados pela Organização Social com terceiros, com recursos públicos, sejam conduzidos de forma pública, objetiva e impessoal, com observância dos princípios do caput do art. 37 da CF, e nos termos do regulamento próprio a ser editado por cada entidade; (v) a seleção de pessoal pelas Organizações Sociais seja conduzida de forma pública, objetiva e impessoal, com observância dos princípios do caput do art. 37 da CF, e nos termos do regulamento próprio a ser editado por cada entidade; e (vi) para afastar qualquer interpretação que restrinja o controle, pelo Ministério Público e pelo TCU, da aplicação de verbas públicas (Brasil 2015, grifo nosso)".

${ }^{14}$ Caroline Müller Bitencourt, Eduardo Dante Calatayud e Janriê Rodrigues Reck, Teoria do Direito e discricionariedade: fundamentos teóricos e crítica do positivismo (Santa Cruz do Sul: Essere nel Mondo, 2014), 219. ${ }^{15}$ No julgamento da ADIn 1923, houve o indeferimento do pleito dos requerentes de ver declarada a inconstitucionalidade do inciso XXIV do art. 24 da Lei n. ${ }^{\circ}$ 8.666/1993, com redação dada pela Lei 9.648/1998, que dispensa a licitação para a celebração de contratos de prestação de serviços com as organizações sociais. 
como pela desnecessidade de certame licitatório nos contratos de aquisição de bens e serviços celebrados pela OS com terceiros, mediante o uso de recursos públicos, já que a flexibilização dos procedimentos revelaria a própria natureza de convênio desses ajustes, o que autorizaria, segundo o STF, ademais, a permissão de uso de bem público sem prévia licitação.

Leal $^{16}$, ao tratar do controle jurisdicional da administração pública em face do problema da discricionariedade, pontua que esta precisa ser repensada e redefinida, de maneira a adequá-la a nova compreensão contemporânea de Estado Gestor vinculado a um sistema jurídico como plexo de valores em potencial estado de concretização, pois a discricionariedade é a exteriorização cotidiana dos atos de governo, não podendo ficar imune à sindicabilidade e controles dos Poderes Estatais.

O Tribunal de Contas da União-TCU mantém entendimento em consonância às disposições do STF quanto à constitucionalidade da Lei 9.637/1998. Porém, a Corte de Contas, dada as distorções que o modelo tem revelado na prática, dirige sua atenção aos aspetos que envolvem a qualificação e seleção das organizações não governamentais pelo Poder Público, sugerindo inclusive a realização de chamamento público para tanto. A preocupação do TCU resulta da sua própria perceção acerca da utilização de critérios não objetivos na escolha de entidades privadas para atuar em colaboração com o Estado e da falta de controle sobre a aplicação dos recursos públicos transpassados ao setor privado por meio desse ambiente de negociação. A chamada pública, ainda que não prevista na Lei 9.637/1998, está positivada atualmente em várias leis municipais e estaduais pautadas no modelo das OS.

Em síntese, considerando-se que "em uma ação comunicativa, a comunicação de agora, vincula a ação e as cadeias de interação do indivíduo para o futuro" ${ }^{17}$, o julgamento da ADIn 1923 pelo STF representa a adesão do Estado brasileiro a uma nova estruturação na forma de prestar serviços públicos sociais, o que que não representa um mal por si só. Entretanto, por meio de uma interpretação constitucional pouco precisa,

\footnotetext{
${ }^{16}$ Rogério Gesta Leal, "Controle da Administração Pública no Brasil: mecanismos de efetivação da transparência na gestão pública", in Patologias corruptivas: as múltiplas faces da bidra, org. Rogério Gesta Leal (Santa Cruz do Sul: EDUNISC, 2015), 94.

${ }^{17}$ Almeida e Reck, Direito \& Ação Comunicativa, 88.
} 
o modelo acabou recebendo contornos práticos mais condizentes com a dinâmica do setor privado, menos sujeito a controles, portanto, e mais suscetível a práticas discricionárias que se distanciam do interesse público.

\section{A abertura às práticas corruptivas por meio da adoção do modelo da "Lei das OS"}

O regime jurídico público no Brasil estabelece a autorização legislativa como pressuposto para a atuação administrativa. Ademais, o gestor público deve observância à regra geral de motivação, fática e jurídica, dos atos administrativos como forma de atestar o interesse público da ação administrativa. Não bastasse, o regime democrático brasileiro se caracteriza pelo contínuo fortalecimento das instituições de controle, como os Tribunais de Contas, de edição de legislação direcionada ao trato da despesa pública, como a Lei 8.666/1993, além da ênfase hoje conferida ao controle social.

Isso quer dizer que a esfera pública, ao possuir parâmetros mais bem delineados de autolimitação, em cotejo com a esfera não estatal que, aprioristicamente, atua sob a égide da autonomia da vontade, deve atuar na contenção dos interesses particulares rumo ao êxito (ações estratégicas) a uma escala socialmente aceitável, ainda mais em se tratando de um país cuja percepção da corrupção atinge níveis tão alarmantes. Nessa linha, interesses privados podem se referir a direitos, mas esta possibilidade é extrínseca, sendo a proteção de direito a essência do interesse público, sob pena de sua desnaturação, ou seja: "Para o interesse público o respeito aos direitos é uma condição necessária; para o interesse privado é apenas uma consequência possivel ${ }^{p 18}$.

Destarte, uma configuração privatista de prestação de serviços públicos reclama do Estado, ao contrário do posicionamento adotado na ADIn 1923, a adoção de institutos jurídicos de cunho mais publicistas, como a licitação e o concurso público. Estes são procedimentos administrativos capazes de produzir ações mais racionais e, portanto, mais aptas a coordenar a ação dos atores envolvidos (setor público x setor privado) evitando a colonização do mundo da vida do primeiro pelo segundo.

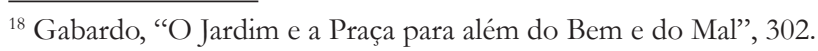


Leal $^{19}$ aponta que a corrupção é um fenômeno de múltiplos fundamentos e nexos causais, não sendo de fácil compreensão e delimitação. Em sua conceção, a diminuição do Estado, as privatizações, a desregulamentação, o fortalecimento dos controles externos e o insulamento burocrático dos centros decisórios da política não geraram os efeitos esperados de controle da corrupção, "podendo-se até questionar se este foi em algum momento um objetivo determinado deste modelo, até porque ele se beneficia indiretamente de algumas relações corruptivas" ${ }^{20}$.

Desse modo o modelo, da forma como instrumentalizado hoje, traz, sem sombra de dúvida, abertura à concessão de privilégios pessoais na contratação de funcionários (ainda que se entenda que esses cargos não são públicos, por não serem criados por lei, tais postos de trabalho são custeados por meio de recursos públicos), além de facilitar mecanismos de preferencias ideológicas na captação de pessoal. Ademais, ao se ampliar a esfera de discricionariedade do responsável por gerir dinheiro público, possibilita-se o descontrole da despesa, o uso indevido e direcionado de subcontratações, a chamada "troca de favores", a mera intermediação de mão de obra de atividades fins da administração pública e a homologação de prestações de contas superficiais que, ao cabo, acabam por impedir uma atuação efetiva das instituições de controle externo, dentre outras incontáveis possibilidades de fraude e patologias corruptivas que a elasticidade própria do modelo pode proporcionar.

É percetível, pelo exposto, que os ajustes do Estado com OS e OSCIPs revelam pouca coordenação da ação entre Estado e as entidades privadas referidas, já que os instrumentos de comunicação utilizados, em geral, são vagos e genéricos e estão amparados por uma interpretação constitucional do modelo de publicização estatal que também se valeu de uma linguagem repleta de lacunas. Em suma, recorre-se a Gabardo $^{21}$ para sinalar que a pós-modernidade retrata uma situação sui generis, já que nunca antes a doutrina liberal foi tão combatida ao mesmo tempo em que a prática

\footnotetext{
${ }^{19}$ Rogério Gesta Leal, "Os descaminhos da corrupcão e seus impactos sociais e institucionais - Causas, consequências e tratamentos", Interesse Público Revista Bimestral de Direito Público 74 (2012): Página 33.

${ }^{20}$ Leal, "Os descaminhos da corrupção e seus impactos sociais e institucionais", 53.

${ }^{21}$ Gabardo, "O Jardim e a Praça para além do Bem e do Mal”, 360.
} 
liberal é tão aplicada, sob a perspetiva da prática governamental de que as ações devem ser pragmáticas e não há outra saída. Para o Autor, em decorrência dessa realidade que "o espirito do Estado social deve desenvolver mais do que um modelo descrito, uma efetiva proposta normativa (que até mesmo ultrapassa o dever ser caracteristicamente jurídico)"22.

\section{Considerações finais}

No atual cenário político-social brasileiro, as instituições públicas estão voltadas ao combate à fraude e corrupção em todas as esferas de governo. Ocorre que a agenda proposta e instituída legalmente pelo modelo privatista de prestação de serviços públicos não contribuiu para equacionar o ideal de eficiência no serviço público no Brasil e de controle da despesa estatal; pelo contrário, a adoção de um regime administrativo mais flexível, pautado, dentre outros aspetos, pela desnecessidade de licitação e de concurso público no âmbito de ajustes entre Estado e OS e OSCIPs distorceu os paramentos de alocação dos recursos públicos, reduziu a transparência sobre o gasto público e contribui para a perda de confiança da população na retórica modernizante. Assim, o trabalho interpretativo do Pretório Excelso acerca da matéria revelou-se demasiado impreciso, especialmente por se tratar de uma decisão que pode alterar profundamente a estrutura do Estado brasileiro, ratificando inclusive a fragilização dos mecanismos de fiscalização sobre as organizações privadas que operam mediante financiamento público, como as OS e OSCIPs. Esse ambiente permite, ao cabo, a conexão desses vínculos com uma atuação demasiado discricionária por parte dos Gestores de dinheiro estatal e com um ambiente propicio a ocorrência de fraude e corrupção, conforme demonstrado nesse ensaio.

${ }^{22}$ Gabardo, "O Jardim e a Praça para além do Bem e do Mal”, 361. 



\title{
$O$ acórdão do Tribunal Constitucional português n. ${ }^{\circ}$ 591/2016 em matéria de concessão de apoio judiciário a pessoas coletivas com fins lucrativos e a jurisprudência do Tribunal de Justiça - reflexões prospetivas à luz da interjurisdicionalidade
}

\author{
Joana Covelo de Abreu*
}

RESUMO: Em novembro de 2016 o Tribunal Constitucional português, auxiliando-se da jurisprudência DEB Deutsche do Tribunal de Justiça da União Europeia (em sede de concessão de apoio judiciário a pessoas coletivas com fins lucrativos), emana um acórdão onde se distancia da sua tendência jurisprudencial maioritária. Na realidade, esta ventilava a não inconstitucionalidade da norma portuguesa que expressamente nega apoio judiciário àquelas pessoas legais. Neste sentido, o Tribunal Constitucional, alicerçando-se no mencionado aresto do Tribunal de Justiça, enceta um diálogo reflexivo entre diferentes jurisdiçoes, importando os desdobramentos realizados pelo tribunal organicamente europeu de modo a legitimar o seu julgamento de inconstitucionalidade, em sede de fiscalização concreta, incidental e difusa, o que deixa antever, em termos pragmáticos e empíricos, o resultado concreto do fenómeno da interjurisdicionalidade. No entanto, o Tribunal Constitucional parece retirar mais do acórdão do Tribunal de Justiça do que seria literalmente possível, percebendo-se que um reenvio prejudicial de interpretação teria dado total resposta aos ensejos buscados pelo tribunal nacional. Ainda assim, é claramente evidente a tendência marcadamente positiva desta jurisprudência que, aliada aos números cada vez mais satisfatórios de interações dos órgãos jurisdicionais portugueses com o Tribunal de Justiça, através do reenvio prejudicial, nos conduzem a intuir que também aqui é cada vez. mais evidente a existência de uma verdadeira integração judiciária.

PAL AV RAS-CHAV E: apoio judiciário-interjurisdicionalidade - integração judiciária - fiscalização da constitucionalidade - DEB Deustche-reenvio prejudicial.

ABSTR ACT: On November 2016, the Portuguese Constitutional Court issues a decision where it walks away from its jurisprudential prevailing tendency by using Court of Justice's DEB Deutsche decision (concerning legal aid concession to legal persons operating for profit). In fact, that jurisprudential prevailing tendency states the non unconstitutionality of the Portuguese rule that expressly denies legal aid to those legal persons. In this sense, the Constitutional Court, using the mentioned Court of Justice's decision, settles a reflexive dialogue between different jurisdictions, importing the European organic court's unfolding so it can legitimate its unconstitutionality judgement in a concrete, incidental and diffuse constitutional control. This lets us foresee, in pragmatic and empirical terms, the concrete result of interjurisdictionality phenomenon. However, the Constitutional Court seems to derive further from the Court of Justice's decision than should be literally possible, so a preliminary ruling of interpretation ought to have given the answer to the aspiration searched by the national court. Still, it is evident a pronouncedly positive trend of this decision which, allied to the numbers more and more satisfactory concerning Portuguese jurisdictional organs' interactions with the Court of Justice, through the preliminary ruling process, lead us to understand that also here it is more clear the existence of a true judicial integration.

KEYWORDS: legal aid - interjurisdictionality - judicial integration - constitutionality control-DEB Deutsche - preliminary ruling.

* Professora da Escola de Direito da Universidade do Minho. Doutora, Mestre e Licenciada em Direito pela Escola de Direito da Universidade do Minho. Bolseira de Doutoramento da FCT de 2012 a 2015. 


\section{Concessão de apoio judiciário a pessoas coletivas com fins lucrativos e a realidade portuguesa}

No âmbito do artigo $47 .^{\circ}, 3^{\circ}$ parágrafo, da CDFUE foi plasmado o direito a gozar de apoio judiciário em circunstâncias de carência económica.

Neste contexto, o direito a apoio judiciário configura-se como instrumental à efetivação do direito de acesso à justiça e aos tribunais "já que este direito fundamental não deve ser denegado por insuficiência de meios económicos"1.

Assim, no que diz respeito ao apoio judiciário, a União Europeia, para além de conter disposições particulares nos Regulamentos de Processo dos tribunais organicamente europeus, também adotou a Diretiva n. ${ }^{\circ}$ 2003/8/CE² de modo a promover o acesso à justiça em contexto transfronteiriço, estabelecendo normas mínimas comuns no domínio do apoio judiciário a conceder mediante litígios emergentes em matérias civis e comerciais.

Neste sentido, Portugal adotou a Lei n. ${ }^{0} 34 / 2004$, que teve o objetivo de parcialmente transpor, para este ordenamento jurídico, a diretiva em apreço. Tal ato normativo dá, aos Estados-Membros, a faculdade de prever condições menos restritivas já que somente estabelece regras mínimas a serem observadas.

A diretiva foi pensada no sentido de promover um melhor acesso à justiça, especialmente daqueles "que não disponham de recursos suficientes", sendo capaz de compreender inteiramente os objetivos prosseguidos pela proclamação de uma tutela jurisdicional efetiva nos termos do disposto no artigo 47. ${ }^{\circ}$ da CDFUE 4 . Afinal, “[a] falta de recursos de uma pessoa implicada num litígio, como demandante ou demandado, bem como as dificuldades resultantes da incidência transfronteiriça de um litígio, não deverão constituir obstáculos a um acesso efetivo à justiça”.

\footnotetext{
${ }^{1}$ Cfr. Maria José Rangel de Mesquita, “Anotação ao artigo 47. ${ }^{\circ}$ da CDFUE”, in Alessandra Silveira e Mariana Canotilho (coords.), Carta dos Direitos Fundamentais da União Europeia Comentada (Coimbra: Almedina, 2013), 544.

${ }^{2}$ Cfr. Diretiva n. ${ }^{\circ}$ 2003/8/CE, do Conselho, de 27 de janeiro de 2003, relativa à melhoria do acesso à justiça nos litígios transfronteiriços, através do estabelecimento de regras mínimas comuns relativas ao apoio judiciário no âmbito desses litígios.

${ }^{3}$ Cfr. Diretiva n. ${ }^{\circ}$ 2003/8/CE, cons. 5 .

${ }^{4}$ Cfr. Diretiva n. ${ }^{\circ}$ 2003/8/CE, cons. 5 .

${ }^{5}$ Cfr. Diretiva n. ${ }^{\circ}$ 2003/8/CE, cons. 6.
} 
Assim, o objetivo da diretiva prende-se com a necessidade de "promover o acesso à justiça de todos que não tenham os meios financeiros necessários de modo a garantir que nenbuma pessoa fique sem defesa porque lhe faltam os recursos financeiros para litigar"

Tal sai particularmente sedimentado porque, antes da adoção da diretiva, todos os Estados-Membros já tinham um sistema próprio de apoio judiciário, mas cada sistema era distinto e com requisitos diferenciados "onde as condições de concessão eram díspares e a sua extensão também acabava por variar"'

No Livro Verde da Comissão sobre a assistência judiciária, foram apontados alguns riscos e obstáculos à tutela jurisdicional efetiva por se verificarem situações de carência económica. Aliás, determina este Livro Verde que " [u]m estudo comparado dos dispositivos nacionais relativos à assistência judiciária demonstra que, na realidade, estes sistemas divergem consideravelmente, o que suscita sérias dificuldades para o litigante envolvido em processos transfronteiras" $"$.

A diretiva permite "uma crescente harmonização entre as legislações dos Estados-Membros, obrigados à sua transposição, em estrito respeito pela sua autonomia processual”.

Neste sentido, a diretiva não define "pessoa coletiva" apenas se referindo a "pessoa singular"10, "resultando da sua interpretação literal que as mesmas [as pessoas coletivas] não gozam deste género de apoio" $"$. A diretiva obriga os Estados-Membros a observarem as suas regras mínimas - impedindo-os de adotar outras mais restritivas - mas deixa-lhes

\footnotetext{
${ }^{6}$ Cfr. Virginia Pardo Iranzo e Rosa Pascual Serrats, "Minimum common regulations on legal aid: Directive 2003/8", in Andrés de Oliva Santos (Director), Maria Pía Calderon Cuadrado, Fernando Gascon Inchausti, Carmen Senés Motilla e Jaime Vegas Torres (Coords.), European Civil Procedure (Madrid, Londres: Aranzadi, Swett \& Maxwell, 2011), 265.

${ }^{7}$ Cfr. Joana Rita de Sousa Covelo de Abreu, "Tribunais nacionais e tutela jurisdicional efetiva: da cooperação à integração judiciária no Contencioso da União Europeia” (Tese de Doutoramento, Escola de Direito da Universidade do Minho, 2014), 279.

${ }^{8}$ Cfr. Comissão Europeia, «Livro Verde»: "Assistência judiciária em material civil: problemas com que se deparam os litigantes em processos transfronteiras", de 9 de Fevereiro de 2000, $\operatorname{COM}(2000) 51$ final, 3. ${ }^{9}$ Cfr. Joana Rita de Sousa Covelo de Abreu, "Tribunais nacionais e tutela jurisdicional efectiva", 279.

${ }^{10}$ Veja-se, a propósito, o artigo 3. ${ }^{\circ}$ da diretiva.

${ }^{11}$ Cfr. Joana Covelo de Abreu, "As interações entre jurisdições no contexto da adesão da União Europeia à Convenção Europeia dos Direitos do Homem: para onde caminha a tutela jurisdicional efetiva? - um exemplo no contexto do apoio judiciário", IX Encontro de Professores de Direito Público (Lisboa: Coleção Colóquios, Universidade Católica Editora, 2017), 136.
} 
a necessária liberdade para estabelecerem um regime mais favorável na sua ordem jurídica interna. Tendo em conta tal suscetibilidade, alguns deles, como é o caso de Portugal, reconhecem a algumas pessoas coletivas a possibilidade de gozarem de apoio judiciário, como se pode derivar da leitura do artigo $7^{\circ}$, n. 3 da Lei n. $34 / 2004$.

Apesar de já termos tido a oportunidade de comentar jurisprudência nacional que interpretou erroneamente o direito da União aplicável ao litígio ${ }^{12}$ - não apenas quanto ao âmbito de aplicação da diretiva mas, de forma mais incisiva, a interpretação do artigo $47 .^{\circ}$ da CDFUE, obliterando a jurisprudência consolidada do Tribunal de Justiça na matéria, nomeadamente o acórdão DEB Deutsche ${ }^{13}$-, novos desenvolvimentos na jurisprudência portuguesa foram detetados, especificamente uma decisão proferida pelo Tribunal Constitucional português. Torna-se, assim, imperioso analisar este acórdão de modo a entender pragmaticamente como o fenómeno da interjurisdicionalidade tem claras demonstrações, pois só assim se conseguirão delinear as estratégias de ação num espaço judiciário integrado como o da União Europeia.

\section{Do acórdão do Tribunal de Justiça DEB Deutsche}

Assim, não poderíamos deixar de analisar o mencionado acórdão DEB Deutsche, uma vez que o Tribunal de Justiça já se havia pronunciado pela possibilidade de também pessoas coletivas gozarem de apoio judiciário. $\mathrm{Na}$ realidade, no âmbito de um reenvio prejudicial ${ }^{14}$ de interpretação, este tribunal organicamente europeu

\footnotetext{
${ }^{12}$ Cfr., para maiores desenvolvimentos, Joana Covelo de Abreu, "As interações entre jurisdições no contexto da adesão da União Europeia".

${ }^{13}$ Cfr. Acórdão TJUE, de 22 de dezembro de 2010, DEB Deutsche, Processo n. ${ }^{\circ}$ C-279/09, ECLI:EU:C:2010:811.

${ }^{14}$ Cfr., para maiores desenvolvimentos, Recomendação do Tribunal de Justiça da União Europeia de 6 de novembro de 2012, Recomendações à atenção dos órgãos jurisdicionais nacionais, relativas à apresentação de processos prejudiciais, 2012/C 338/01, http://eur-lex.europa.eu/legal-content/PT/TXT/ PDF/?uri=CELEX:32012H1106(01)\&qid=1496908779643\&from=PT. No mesmo sentido, e para análise dogmática, cfr. Joana Covelo de Abreu, "Anotação ao Despacho do Tribunal de Justiça (10. Secção) de 16 de julho de 2015 - Processo n. ${ }^{\circ}$ C-507/14", in Anuário de Direito Internacional 2014/ 2015
} 
reformulou a questão submetida pelo tribunal nacional no sentido de aferir se, à luz da tutela jurisdicional efetiva, acautelada nos termos do artigo 47. ${ }^{\circ}$ da CDFUE, poderia uma pessoa coletiva com fins lucrativos gozar de apoio judiciário quando a sua não concessão determinasse a impossibilidade de tal pessoa coletiva poder exercer, em juízo, os seus direitos ${ }^{15}$.

Neste sentido, o Tribunal de Justiça recorda que, apesar de o artigo 47. ${ }^{\circ}$ da CDFUE apenas falar em pessoa - parecendo referir-se a "indivíduos" -, não exclui as pessoas coletivas já que, sistematicamente, no título em que se insere este artigo "estão consagrados outros princípios processuais que se aplicam tanto às pessoas singulares como às pessoas coletivas" ${ }^{16}$. Por sua vez, como o apoio judiciário não foi um direito incluído no título relativo à solidariedade, não pode ser entendido apenas como um “direito social' a fim de se extrair que "só deverá ser concedido às pessoas singulares"17.

Mais concretamente, o Tribunal de Justiça justifica que, apesar de a diretiva não abrir a porta a que também as pessoas coletivas gozem de apoio judiciário, tal não configura um argumento irrefutável de que a CDFUE afaste tal suscetibilidade, não se podendo daí "extrair uma conclusão de caráter geral"18.

Não se encontrando, à partida, afastada a possibilidade de conceder apoio judiciário às pessoas coletivas, o Tribunal de Justiça afiança, no considerando 52 deste aresto, que tal concessão terá de ser aferida tendo por referência a situação da sociedade em causa, nomeadamente a sua situação económica e financeira. Deste modo, "[n]o quadro da tomada em consideração da capacidade financeira do requerente, tratandose de uma pessoa coletiva, pode atender-se, nomeadamente à forma da sociedade - sociedade de capitais ou de pessoas, sociedade de responsabilidade limitada ou não - à capacidade financeira dos respetivos sócios, ao objeto social da sociedade, às modalidades da sua constituição e, em especial, à relação entre os meios que lhe foram atribuidos e a atividade a que pretende dedicar-se" 19 .

(Lisboa: Instituto Diplomático, Ministério dos Negócios Estrangeiros, 2016).

${ }^{15}$ Cfr. Acórdão DEB Deutsche ..., cons. 33.

${ }^{16}$ Cfr. Acórdão DEB Deutsche..., cons. 40.

${ }^{17} \mathrm{Cfr}$. Acórdão DEB Deutsche..., cons. 41.

${ }^{18}$ Cfr. Joana Covelo de Abreu, "As interações entre jurisdições no contexto da adesão da União Europeia", 139.

${ }^{19} \mathrm{Cfr}$. Acórdão DEB Deutsche..., cons. 54. 
Perante tais considerações, o Tribunal de Justiça respondeu que "o princípio da proteção jurisdicional efetiva, como consagrado no artigo $47 .^{\circ}$ da Carta, deve ser interpretado no sentido de que não está excluido que possa ser invocado por pessoas coletivas e que o apoio concedido em aplicação deste princípio pode abranger, designadamente, a dispensa de pagamento antecipado dos encargos judiciais e / ou a assistência de um advogado" ${ }^{20}$, cabendo "ao órgão jurisdicional nacional verificar se os requisitos de concessão do apoio judiciário constituem uma limitação do direito de acesso aos tribunais suscetivel de prejudicar a essência desse direito, se têm um objetivo legítimo e se existe uma relação raz̧óvel de proporcionalidade entre os meios utilizados e o objetivo prosseguido" 21 . Neste contexto, o Tribunal de Justiça reconhece, ao tribunal nacional, a faculdade de equacionar, nesse seu juízo, "o objeto do litígio, as hipóteses razoáveis de sucesso do requerente, a gravidade do que está em causa para este, a complexidade do direito e do processo aplicáveis bem como a capacidade de o requerente defender efetivamente a sua causa" ${ }^{22} \mathrm{e}$, concretamente no que diz respeito à proporcionalidade, tomar em consideração " $a$ importância dos encargos judiciais que deve ser paga antecipadamente e o carácter insuperável, ou não, do obstáculo que estes eventualmente representam para efeitos do acesso à justiça"23.

Finalizando, o Tribunal de Justiça concretiza as suas construções entendendo que, tratando-se de pessoas coletivas, caberá ao tribunal nacional "tomar em consideração a situação destas [...] designadamente, a forma e o fim lucrativo ou não da pessoa coletiva em causa bem como a capacidade financeira dos seus sócios ou acionistas e a possibilidade de estes obterem as quantias necessárias para a propositura da ação"24.

Deste modo, "o Tribunal de Justiça não fecha a porta a que as pessoas coletivas também possam gozar, por força do direito da União, de apoio judiciário. Contudo, deriva esta conclusão do fenómeno da interconstitucionalidade que subjaz ao processo de integração" ${ }^{25}$ : no caso, para além das conclusões vertidas neste acórdão derivarem das fontes que vivem em tensão comunicativa na União Europeia - a saber, "a jurisprudência consolidada do

\footnotetext{
${ }^{20}$ Cfr. Acórdão DEB Deutsche..., cons. 59.

${ }^{21}$ Cfr. Acórdão DEB Deutsche..., cons. 60.

${ }^{22} \mathrm{Cfr}$. Acórdão DEB Deutsche..., cons. 61.

${ }^{23}$ Cfr. Acórdão DEB Deutsche..., cons. 61.

${ }^{24}$ Cfr. Acórdão DEB Deutsche..., cons. 62.

${ }^{25}$ Cfr. Joana Covelo de Abreu, "As interações entre jurisdições no contexto da adesão da União Europeia", 140.
} 
TEDH, que ajuda a interpretar as disposições da CDFUE (que foi beber influências às tradições constitucionais comuns aos Estados-Membros e aos instrumentos de proteção de direitos humanos de caráter internacional, de onde se destaca a CEDH) -, o Tribunal de Justiça derivou, sistemática e literalmente, da CDFUE que também as pessoas coletivas poderão gozar de apoio judiciário em situaçôes de carência económica" ${ }^{26}$.

Assim, este é o pano de fundo que nos permite, com a análise da jurisprudência mais recente do Tribunal Constitucional português, falar numa verdadeira "interjurisdicionalidade", explicando o fenómeno alicerçado no exemplo paradigmático do apoio judiciário e da sua possibilidade de concessão a pessoas coletivas.

\section{O Acórdão do Tribunal Constitucional n. ${ }^{\circ} 591 / 2016$, de 9 de novembro de 2016}

A análise do acórdão emanado pelo Tribunal Constitucional português no dia 9 de novembro de 2016 prende-se com a sensibilidade que o mesmo gera à luz dos fenómenos da interjurisdicionalidade.

Afinal, tendo por referência os ensinamentos de Gomes Canotilho, "[e]m termos de interjurisdicionalidade, interessa verificar se a articulação de vários niveis de acesso aos tribunais pode ou não traduzir-se em restrições à abertura da via judiciária"27. Assim, tomando por referência a teoria da interconstitucionalidade ${ }^{28}$ desenhada por este autor, aventamos uma definição de interjurisdicionalidade, também veiculada por outros autores que se dedicam ao estudo dos fenómenos "inter-" 29 : interjurisdicionalidade pretende

\footnotetext{
${ }^{26}$ Cfr. Joana Covelo de Abreu, "As interações entre jurisdições no contexto da adesão da União Europeia", 140.

${ }^{27}$ Cfr. José Joaquim Gomes Canotilho, "Estado de direito e internormatividade", in Alessandra Silveira (Coord.), Direito da União Europeia e Transnacionalidade, (Lisboa: Ação Jean Monnet Information and Research Activities, Quid Juris, 2010), 178.

${ }^{28}$ Cfr., para maiores desenvolvimentos, José Joaquim Gomes Canotilho, "Brancosos" e Interconstitucionalidade. Itinerários dos discursos sobre a bistoricidade constitucional (Coimbra: Almedina, 2006).

${ }^{29}$ A propósito do conceito de interconstitucionalidade ou de constitucionalismo plural - caracterizadores do processo de integração europeu pós-Lisboa - cfr., entre outros, José Joaquim Gomes Canotilho, "Brancosos" e Interconstitucionalidade; Paulo Castro Rangel, O estado do Estado. Ensaios de política constitucional sobre justiça e democracia (Lisboa: Dom Quixote, 2009); Miguel Poiares Maduro, A Constituição Plural.
} 
significar a convivência de diferentes e complementares sistemas jurisdicionais no mesmo espaço jurídico-constitucional e estudar como as suas interações reflexivas podem ser mantidas de modo a promover, na plenitude, a observância de uma tutela jurisdicional efetiva ${ }^{30}$.

Assim, e como poderemos depreender ao longo do presente contributo, tratase de uma necessária aproximação à matéria atinente ao apoio judiciário de modo a entender como o Tribunal Constitucional português lidou com o problema.

No dia 9 de novembro de 2016, o Tribunal Constitucional português emanou o acórdão n. ${ }^{\circ}$ 591/2016, operando um julgamento de inconstitucionalidade, em sede de fiscalização concreta, incidental e difusa, da norma do artigo $7^{\circ}$, n. $^{\circ} 3$ da Lei n. $.^{\circ} 34 / 2004^{31}$.

$\mathrm{Na}$ ação principal, uma sociedade anónima apresentou, perante a autoridade administrativa competente (o Instituto de Segurança Social, I.P. - Centro Distrital

Constitucionalismo e União Europeia (Cascais, Principia, 2006); Miguel Poiares Maduro, "Three Claims of Constitutional Pluralism", in Matej Avbelj e Jan Komarek (Eds.), Constitutional pluralism in the European Union and beyond (Oxford: Hart Publishing, 2012); Alessandra Silveira, "Intersubjectividade, interdemocraticidade, interconstitucionalidade, Filosofia Política e juridicidade europeia", in Joao Cardoso Rosas e Vitor Moura (Orgs.), Pensar radicalmente a humanidade, Ensaios em homenagem ao Prof. Doutor Acílio da Silva Estanqueiro Rocha (Braga: Edições Humus, Universidade do Minho, Centro de Estudos Humanísticos, 2011); Alessandra Silveira, Pedro Madeira Froufe e Mariana Canotilho, "Portuguese Repor"t, in Julia Laffranque (Ed.), "The protection of fundamental rights post-Lisbon: the interaction between the Charter of Fundamental Rights of the European Union, the European Convention on Human Rights and National Constitutions", Reports of the XXV FIDE Congress (Vol. I, Tallinn: Tartu University Press, 2012); Di Federico Giacomo, "Fundamental rights in the EU: Legal pluralism and multi-level protection after the Lisbon Treaty", in Di Federico Giacomo (Ed.), The EU Charter of fundamental rights: from Declaration to Binding Instrument (Heidelberg: Springer, Ius Gentium - Comparative Perspectives on Law and Justice 8, 2011); Alexander Egger, "EU-fundamental rights in the national legal order: the obligations of the Member States revisited", in Yearbook of European Law, 25 (2006); Leonard Besselink, "Entrapped by the maximum standard: on fundamental rights, pluralism and subsidiarity in the European Union", Common Market Law Review, 35 (1998); Joseph H. Weiler e Nicholas Lokhart, "Taking rights seriously: the European Court and its fundamental rights jurisprudence, Parts I and II", Common Market Law Review, 32 (1995); Christiaan Timmermans, "Multilevel judicial co-operation", in Pascal Cardonnel, Allan Rosas e Mils Wahl (Eds.), Constitutionalising the EU Judicial System: Essays in honour of Pernilla Lindh (Oxford: Hart Publishing, 2012).

${ }^{30}$ Tal definição decorre ainda da noção aventada no programa do workshop cuja publicação das participações ora se promove: "a interjurisdicionalidade diz respeito à interação entre ordens jurisdicionais e as suas implicações na tutela jurisdicional efetiva", interação essa que a Autora descreveria como reflexiva (como o fez, na sua intervenção oral).

31 A norma do artigo 7. ${ }^{\circ}$, n. 3 da Lei n. ${ }^{\circ}$ 34/2004 dispõe: "[a]s pessoas coletivas com fins lucrativos e os estabelecimentos individuais de responsabilidade limitada não têm direito a proteção jurídica". 
de Braga), um requerimento de concessão de apoio judiciário, que foi rejeitado liminarmente com base no mencionado artigo 7. ${ }^{\circ}$, n. 3 da Lei n..$^{\circ}$ 34/2004.

Não se conformando, a sociedade anónima impugnou judicialmente tal decisão invocando, perante o tribunal competente de primeira instância, a inconstitucionalidade da norma do artigo $7 .^{\circ}$, n. 3 da mencionada lei e, simultaneamente, "a sua contrariedade relativamente ao direito da União Europeia, em particular no que respeita ao artigo $47 .^{\circ} \mathrm{da}$ Carta dos Direitos Fundamentais da União Europeia"32.

O tribunal de instância negou provimento à impugnação por "manifesta inviabilidade" dando conta, entre outros argumentos, que a legislação nacional aplicável não era inconstitucional já que o artigo $20 .^{\circ}$ da CRP, tratando-se de um conceito programático, demanda concretização por legislação ordinária e, assim, a limitação decorrente da legislação aplicável não compromete o padrão jusconstitucional já que existem outros mecanismos jurisdicionais que poderão ser utilizados pela pessoa coletiva se esta se encontrar em situação económica difícil ou em situação de insolvência atual ou iminente.

Relativamente ao direito da União Europeia invocado pela parte, o tribunal de instância nada mencionou no excerto dado a conhecer no acórdão do Tribunal Constitucional. Por sua vez, nada indica quanto à obrigação que sobre si impendia de proceder a uma interpretação conforme do direito interno à luz do direito da União, de acordo com os seus princípios gerais de direito ou sobre a sua faculdade ilimitada de reenviar para o Tribunal de Justiça.

Não se resignando com tal decisão, a impugnante interpôs recurso de constitucionalidade, perante o Tribunal Constitucional, a fim de este se pronunciar da compatibilidade do artigo $7 .^{\circ}$, n. $^{\circ} 3$ com, entre outros, o artigo $20 .^{\circ 33} \mathrm{da}$ CRP.

\footnotetext{
32 Cfr. Acórdão Tribunal Constitucional n. ${ }^{\circ}$ 591/2016, http://www.tribunalconstitucional.pt/tc/ acordaos/20160591.html, 1.

${ }^{33}$ Reza o artigo 13. ${ }^{\circ}$ da CRP, sob a epígrafe "Acesso ao direito e tutela jurisdicional efetiva":

"1. A todos é assegurado o acesso ao direito e aos tribunais para defesa dos seus direitos e interesses legalmente protegidos, não podendo a justiça ser denegada por insuficiência de meios económicos.

2. Todos têm direito, nos termos da lei, à informação e consulta jurídicas, ao patrocinio judiciário e a fazer-se acompanhar por advogado perante qualquer autoridade.

3. $[\cdots]$
} 
Relativamente à fundamentação do recurso, o Tribunal Constitucional entendeu que o artigo $7^{\circ}$, n. 3 da Lei n. ${ }^{\circ}$ 34/2004 é inconstitucional porque " 0 acesso aos tribunais [...] é uma garantia imprescindivel da proteção de direitos fundamentais e, como tal, inerente à ideia de Estado de direito: sem prejuizo da sua natureza de direito prestacionalmente dependente e de direito legalmente conformado, certo é que ninguém - pessoa singular ou pessoa coletiva, nacional ou não nacional - pode ser privado de levar a sua causa à apreciação de um tribunal’34.

Assim, "[o] conteúdo deste direito não pode ser esvaziado ou praticamente inutilizado por insuficiência de meios económicos" 35 .

Acresce que a aceitação da exclusão completa e absoluta de pessoas coletivas com fins lucrativos da ratio e teleologia do sistema de apoio judiciário configuraria o afastamento de toda uma categoria de pessoas (que também têm direito de aceder aos tribunais para exercer jurisdicionalmente os seus direitos) de um direito que é reconhecido simultaneamente pela Constituição nacional e também por regimes internacionais de proteção de direitos fundamentais / direitos humanos juridicamente vinculativos, aos quais Portugal se encontra submetido. Assim, o Tribunal Constitucional aventa que se deve proceder à avaliação da situação económica da pessoa coletiva em questão a fim de prevenir que se determine, em absoluto e de forma desproporcionada, que as pessoas coletivas com fins lucrativos fiquem totalmente afastadas do sistema de apoio judiciário em situação de carência económica.

No entanto, de forma particularmente mais premente, temos de atentar aos n. ${ }^{\text {s }}$ 7 e 8 da fundamentação da decisão em apreço a fim de intuirmos o fenómeno da interjurisdicionalidade nela presente.

Ora, em decisões anteriores, o Tribunal Constitucional entendeu que é diferente a situação de carência económica vivenciada por pessoas coletivas e por pessoas

\footnotetext{
4. Todos têm direito a que uma causa em que intervenham seja objeto de decisão em prazo razoável e mediante processo equitativo.

5. Para defesa dos direitos, liberdades e garantias pessoais, a lei assegura aos cidadãos procedimentos judiciais caracterizados pela celeridade e prioridade, de modo a obter a tutela efetiva e em tempo útil contra ameaças ou violaçoes desses direitos".

${ }^{34}$ Cfr. Acórdão Tribunal Constitucional n. ${ }^{\circ} 591 / 2016,3$, n. ${ }^{\circ} 4$, 2. $^{\circ}$ parágrafo.

${ }^{35}$ Cfr. Acórdão Tribunal Constitucional n. ${ }^{\circ} 591 / 2016,3$, n. ${ }^{\circ} 4$, 2. $^{\circ}$ parágrafo.
} 
singulares e o seu impacto em sede de acesso aos tribunais na medida em que os custos decorrentes do exercício jurisdicional dos direitos conferidos a pessoas coletivas com fins lucrativos já deve ser entendido como uma despesa inerente à sua atividade, acrescentando ainda que tais despesas ainda poderão ser minoradas já que "os custos derivados de contencioso [podem ser] deduzidos aos rendimentos das pessoas coletivas pelo que, apesar de serem suportados inicialmente, acabam por ser abatidos para efeitos de determinação da matéria coletável, ou mesmo quando a ação é alheia à atividade económica da empresa" ${ }^{36}$.

Ademais, o Tribunal Constitucional considerou que a concessão de apoio judiciário a pessoas coletivas com fins lucrativos acabaria por criar uma afetação desfavorável dos mercados, gerando um desequilíbrio nas relações concorrenciais entre empresas e afetando a sua competitividade ${ }^{37}$.

Seguindo a lógica aventada pela maioria das decisões antecedentes, o Tribunal Constitucional, na decisão ora sob escrutínio, demonstra que, então, "o apoio judiciário a pessoas coletivas com fins lucrativos surge como disfuncional e potencialmente criador de desigualdades entre as empresas concorrentes num mesmo mercado e, por essa via, como potencial fator de desequilíbrio desse mercado"38.

No entanto, distancia-se desta jurisprudência, mostrando-se inovador ao invocar a jurisprudência DEB Deutsche do Tribunal de Justiça. Afinal, alicerçandose na jurisprudência consolidada do Tribunal de Justiça, o Tribunal Constitucional português chegou à conclusão que "[e]ste entendimento [ventilado pelo Tribunal de Justiça] do princípio da proteção jurisdicional efetiva consagrado no artigo $47 .^{\circ}$ da CDFUE afasta a ideia de uma necessária incompatibilidade entre o apoio judiciário prestado a pessoas coletivas com fins lucrativos e o bom funcionamento de mercados concorrenciais, como é o caso do mercado interno"39. Afiança ainda que "o apoio judiciário não constitui forçosamente um fator de distorção da concorrência ou de favorecimento da litigância de sociedades comerciais; [...] o mesmo não pode

\footnotetext{
${ }^{36}$ Cfr. Acórdão Tribunal Constitucional (Plenário) n. ${ }^{o}$ 216/2010, http://www.tribunalconstitucional.pt/ tc/acordaos/20100216.htmlimpressao $=1,11$, n. $^{\circ} 13,8 .^{\circ}$ parágrafo

37 Para maiores desenvolvimentos, cfr. Acórdão Tribunal Constitucional n. ${ }^{\circ}$ 671/2014 e Decisões Sumárias n. ${ }^{\circ}$ s 379/2013, 343/2014, 717/2015, 54/2016, 142/2016 e 143/2016, http://www. tribunalconstitucional.pt/tc/acordaos/\# e http://www.tribunalconstitucional.pt/tc/decsumarias/

${ }^{38}$ Cfr. Acórdão Tribunal Constitucional n. ${ }^{\circ} 591 / 2016,6$, n. $^{\circ}$ 7, 3. ${ }^{\circ}$ parágrafo.

${ }^{39}$ Cfr. Acórdão Tribunal Constitucional n. ${ }^{\circ} 591 / 2016,7$, n. ${ }^{\circ} 8,4 .^{\circ}$ parágrafo.
} 
ser equiparado ou qualificado como um auxílio concedido pelo Estado ou proveniente de recursos financeiros públicos que falseia ou ameaça falsear a concorrência, favorecendo certas empresas" ${ }^{40}$.

Nesta senda, o Tribunal Constitucional ainda demonstra uma preocupação sistemática: "[b] asta pensar na hipótese de uma sociedade comercial, portuguesa ou nacional de um outro Estado-Membro da União Europeia, em dificuldades económicas devido à violação de normas de direito da União Europeia pelo Estado Português e que pretende efetivar a responsabilidade civil deste último: a impossibilidade absoluta de discutir - é esse o sentido da rejeição do pedido de proteção jurídica decidida in casu pelo recorrido - com as autoridades portuguesas competentes a sua insuficiência económica para efeitos de obtenção de proteção jurídica necessária a assegurar proteção jurisdicional efetiva é contrária ao artigo 47.', terceiro parágrafo, da CDFUE e coloca-a numa situação de desigualdade face às sociedades em situação paralela noutros Estados-Membros" "41.

Como podemos derivar, o Tribunal Constitucional português muniu-se de uma capacidade interpretativa que lhe permitiu, usando o direito da União aplicável à matéria, dar um novo arranjo jurisdicional à ideia de concessão de apoio judiciário a pessoas coletivas com fins lucrativos, potenciando o seu afastamento relativamente à jurisprudência constitucional maioritária que antecedeu este acórdão.

\section{Algumas reflexões prospetivas e a pragmática perceção da interjurisdicionalidade}

Feita a análise casuística do acórdão do Tribunal Constitucional, cabe-nos tentar extrair algumas conclusões e expor o fenómeno da interjurisdicionalidade que aí se encontra patente.

Assim, no que diz respeito à interpretação do artigo $47 .^{\circ}, 3^{\circ}{ }^{\circ}$ parágrafo da CDFUE, o Tribunal Constitucional conseguiu absorver a inovação inerente ao entendimento relativo ao apoio judiciário e a sua possibilidade de concessão a pessoas coletivas com fins lucrativos decorrente do acórdão DEB Deutsche - o que revela, à saciedade, que o Tribunal Constitucional português foi beber a interpretação

\footnotetext{
${ }^{40}$ Cfr. Acórdão Tribunal Constitucional n. ${ }^{\circ} 591 / 2016,8$, n. $^{\circ} 8,4$. $^{\circ}$ parágrafo.

${ }^{41}$ Cfr. Acórdão Tribunal Constitucional n. ${ }^{\circ} 591 / 2016,8$, n. $^{\circ} 8$, 5. $^{\circ}$ parágrafo.
} 
jurídica do direito da União realizada, previamente, pelo Tribunal de Justiça, dando observância ao fenómeno da interjurisdicionalidade. Afinal, o reenvio prejudicial não serve apenas para, in casu, suscitar as dúvidas interpretativas / de validade ao Tribunal de Justiça. Tem também uma capacidade de ser gerador de um acervo jurisprudencial que se fixa inelutavelmente como fonte imediata de direito da União, à disposição de todos os ordenamentos jurídicos nacionais; não fica, portanto, estribado a produzir efeitos inter partes, apenas no litígio onde o reenvio prejudicial foi realizado. Afinal, o próprio Tribunal de Justiça o refere, dizendo que "[o] reenvio prejudicial é um mecanismo fundamental do direito da União Europeia, que tem por finalidade fornecer aos órgãos jurisdicionais dos Estados-Membros o meio de assegurar uma interpretação e uma aplicação uniformes deste direito em toda a União" ${ }^{\prime 2}$. Assim, a interação reflexiva entre ordens jurisdicionais que convivem no mesmo espaço jurídico não se esgota no exercício presente de um reenvio prejudicial, mas resulta também (e, em termos práticos, de forma mais premente) da capacidade de um órgão jurisdicional nacional ser capaz de se auxiliar da jurisprudência consolidada do Tribunal de Justiça e de a aplicar à situação que tem perante si - "[o] processo prejudicial assenta na colaboração entre o Tribunal [de Justiça] e os órgãos jurisdicionais dos Estados-Membros" ${ }^{\text {*3 }}$. Ora, tal fenómeno foi cabalmente absorvido pelo Tribunal Constitucional na decisão que ora analisamos.

No entanto, apesar de se verificar esta aproximação - que, por si só, dava resposta às dúvidas quanto ao sentido a dar à tutela jurisdicional efetiva neste contexto de interconstitucionalidade em que Portugal se insere -, a realidade é que a jurisprudência do Tribunal de Justiça é chamada à colação para dispersar dúvidas interpretativas relativamente ao facto de a concessão de apoio judiciário a empresas poder configurar (ou não) uma distorção proibida ao bom funcionamento do mercado interno e, bem assim, atentatória da livre concorrência que se pretende promover neste contexto. Mais concretamente, a jurisprudência do Tribunal de Justiça é usada para afastar a seguinte dúvida concretizada: se a concessão de apoio judiciário a pessoas coletivas

\footnotetext{
${ }^{42}$ Cfr. Tribunal de Justiça da União Europeia, "Recomendações à atenção dos órgãos jurisdicionais nacionais, relativas à apresentação de processos prejudiciais": 1, n. $^{\circ} 1$.

${ }^{43}$ Cfr. Tribunal de Justiça da União Europeia, "Recomendações à atenção dos órgãos jurisdicionais nacionais, relativas à apresentação de processos prejudiciais": 2, n. ${ }^{\circ} 5$.
} 
com fins lucrativos se pode configurar como um auxílio de Estado, no sentido e para os efeitos do disposto no artigo $107 .^{\circ}$ do TFUE?

Ora, parece-nos que o Tribunal Constitucional conseguiria distanciar-se da sua jurisprudência anterior sedimentando esta sua decisão no acórdão DEB Deutsche, por força da efetivação de uma verdadeira tutela jurisdicional; no entanto, usando tal aresto como fundamento, o Tribunal Constitucional discorreu, das entrelinhas da decisão do Tribunal de Justiça, algo completamente inovador: que a concessão de apoio judiciário a empresas não se configura um auxílio de Estado e, portanto, não tem a veleidade de distorcer a concorrência.

Ora, tal aparece como uma nova leitura, que demandava que o Tribunal Constitucional reenviasse as suas dúvidas interpretativas para o Tribunal de Justiça só assim promovendo a verdadeira finalidade integradora inerente a tal mecanismo de diálogo ${ }^{44}$ entre tribunais...

Daqui se deduz que o Tribunal Constitucional, apesar de sensibilizado à congruente aplicação do direito da União Europeia, parece ainda não saber até que momento poderá exercer uma interpretação dos termos dos acórdãos do Tribunal de Justiça ou quando será adequado promover um reenvio prejudicial.

$\mathrm{Na}$ realidade, o Tribunal Constitucional deveria ter levado ao conhecimento do Tribunal de Justiça uma questão prejudicial onde tentasse aferir se, à luz da jurisprudência DEB Deutsche, e tendo em conta a interpretação do artigo $107 .{ }^{\circ}$ do TFUE, a concessão de apoio judiciário a pessoas coletivas com fins lucrativos poderia configurar uma distorção da concorrência por se tratar de um auxílio de Estado - o que, em termos de reenvio prejudicial, acabaria por se configurar como um reenvio de interpretação, na medida em que encerrava em si dúvidas interpretativas atinentes ao sentido a dar à disposição de direito originário do artigo 107. ' do TFUE e a leitura da jurisprudência DEB Deutsche neste contexto.

Parece, assim, que o Tribunal Constitucional perdeu uma oportunidade para, de uma vez por todas, afastar as dissidências jurisprudenciais quanto à

\footnotetext{
${ }^{44}$ Sobre a dicotomia "diálogo formal / diálogo informal" atinente às relações entre o Tribunal de Justiça e os tribunais nacionais, cfr. Christiaan Timmermans, "Multilevel judicial co-operation".
} 
constitucionalidade do artigo $7 .^{\circ}$, n. ${ }^{\circ} 3$ da Lei n. ${ }^{\circ} 34 / 2004$, quer fazendo - como fez! - referência ao acórdão DEB Deustche (quanto à interpretação da tutela jurisdicional efetiva e, concretamente, do artigo $47 .^{\circ}, 3^{\circ}$ parágrafo da CDFUE), quer reenviando as suas dúvidas a fim de demonstrar que tal não configuraria um auxílio de Estado, na aceção do artigo $107 .^{\circ}$ do TFUE.

Simultaneamente, poderia, no seu reenvio de interpretação, questionar o Tribunal de Justiça se, quando este dispõe que a concessão de apoio judiciário a pessoas coletivas com fins lucrativos ocorra pela cuidadosa aferição da sua situação económica, no acórdão DEB Deutsche, não está, deste modo e implicitamente, a evitar que tal apoio judiciário se configure como um auxílio de Estado. No entanto, para o efeito, apenas um reenvio prejudicial poderia dirimir tais dúvidas e, bem assim, servir cabalmente o propósito do Tribunal Constitucional em afastar a jurisprudência consolidada anteriormente.

No entanto, esta é uma reflexão prospetiva - e animada! - já que, além de uma clara predisposição do Tribunal Constitucional português a bem aplicar direito da União, chamamos a atenção para a recente publicação do Relatório Anual do Tribunal de Justiça, relativo ao ano de $2016^{45}$.

Assim, da sua análise resulta que o número de reenvios prejudiciais portugueses se encontra a aumentar - cifrando-se, em 2016, em 21 reenvios prejudiciais ${ }^{46}$ - o que nos permite antever que há um claro aumento de sensibilidade dos operadores judiciários nacionais. Acresce que há uma tendência em diminuir o tempo de decisão do Tribunal de Justiça - afinal, de acordo com o Relatório Anual, o Tribunal de Justiça decidiu, em média, em 14,7 meses e, atenta a média global da duração dos

\footnotetext{
${ }^{45}$ Cfr. "Relatório Anual 2016 - "Panorama do Ano", Tribunal de Justiça da União Europeia, acesso em junho 8, 2017, https://curia.europa.eu/jcms/upload/docs/application/pdf/2017-04/ti_pubpdf_ qdaq17001ptn_pdfweb_20170424163218.pdf.

${ }^{46}$ Cfr. "Annual Report 2016 - "Judicial activity" (provisional version)", Court of Justice of the European Union, acesso em junho 8, 2017, https://curia.europa.eu/jcms/upload/docs/application/pdf/201703/ra_jur_2016_en_web.pdf, 108, quadro 19. - "New references for a preliminary ruling (by Member State per year)".
} 
processos neste e no Tribunal Geral, a duração se cifra em 16,7 meses ${ }^{47}$. Assim, se a preocupação se prende com demoras processuais excessivas, esta começa, paulatinamente, a ser minorada.

Por sua vez, não deixa de ser um claro incentivo ver o Tribunal Constitucional português demonstrar tal sensibilidade ao direito da União; ora, poderia, contudo, ter sido ainda mais contundente se o reenvio se tivesse operado, de modo a permitir que todos os Estados-Membros pudessem gozar dos desdobramentos jurisprudenciais realizados pelo Tribunal de Justiça na senda de um reenvio português...

Daqui também se deriva que, ainda que se intuam algumas resistências dos órgãos jurisdicionais portugueses de cúpula em reenviar - não será, julgamos, outra a razão para que o Tribunal Constitucional português nunca tenha reenviado -, a realidade é que se nota uma clara evolução da sua jurisprudência, verificando-se que, neste contexto específico da concessão de apoio judiciário, que este Tribunal se sedimentou na decisão do Tribunal de Justiça para se afastar da jurisprudência maioritária nele veiculada.

Este sentido decisório acaba por vir, nesta sede, alicerçar a nossa convicção que a União Europeia se encontra a viver, nos dias de hoje, uma verdadeira integração judiciária. Aliás, muito recentemente, o Juiz Conselheiro Cruz Vilaça (Juiz no Tribunal de Justiça) sugeriu que o adensamento das componentes federativas do sistema da União Europeia passa pelo aprofundamento do que já existe neste contexto, tendo este Juiz incitado a que a cooperação entre o Tribunal de Justiça e os tribunais nacionais deve manter-se e continuar a adensar a sua "fertilização cruzada", promovendo-se uma "justiça em rede" com "mecanismos de qualidade de cooperação e de aprofundamento do diálogo" 48 .

De qualquer forma, o aprofundamento e densificação desta integração judiciária

\footnotetext{
${ }^{47}$ Cfr. Tribunal de Justiça da União Europeia, Relatório Anual 2016 - "Panorama do Ano”..., 15.

${ }^{48}$ Estas expressões resultam da intervenção do Juiz Conselheiro José Luís da Cruz Vilaça, na qualidade de orador convidado, no painel "A União Europeia como sistema federal suis generis: crise e desafios recentes" (dia 22 de maio de 2017), no âmbito da Conferência "The federal experience of the European Union: past, present and future", que teve lugar na Faculdade de Direito da Universidade Nova de Lisboa, Campus de Campolide, nos dias 22 e 23 de maio de 2017, em Lisboa.
} 
passa pela observância mais sedimentada do fenómeno da interjurisdicionalidade, na medida em que é da interação entre os tribunais nacionais e o Tribunal de Justiça que se sedimenta uma verdadeira integração judiciária no contexto da União. 



\title{
Implicações fiscais das disposições do TFUE relativas aos auxílios de Estado
}

\author{
João Sérgio Ribeiro*
}

RESUMO: O artigo que se inicia tem como objetivo faz̧er uma breve introdução às implicações fiscais das disposições do Tratado sobre o Funcionamento da União Europeia (TFUE) relativas aos auxílios de Estado. Nesse contexto, depois de fazer uma delimitação do tema, o autor dará conta dos principais desafios que se colocam quando se lida com os Auxílios de Estado no campo da tributação.

PALAV RAS-CHAVE: auxílios de Estado - Direito Fiscal da União Europeia.

ABSTR ACT: This article seeks to make a brief introduction to the tax consequences of the provisions of the Treaty on the Functioning of the European Union (TFEU) that deal with State Aid. In that context, after mapping out the topic, the author will address the main challenges that have to be faced when dealing with State Aid in the field of taxation.

KEYWORDS: State aid-European Tax Law.

\footnotetext{
* Diretor do LL.M. in European and Transglobal Business Law da Universidade do Minho. Membro Doutorado do Centro de Estudos em Direito da União Europeia - CEDU.
} 


\section{Direito da União Europeia e proibição dos auxílios de Estado}

O controlo dos auxílios de Estado faz parte do Direito Europeu da Concorrência e tem como principal suporte o artigo 107. ${ }^{\circ}$, n. 1 do TFUE, de onde decorre que "salvo disposição em contrário dos Tratados, são incompativeis com o mercado interno, na medida em que afetem as trocas comerciais entre os Estados-Membros, os auxílios concedidos pelos Estados ou provenientes de recursos estatais, independentemente da forma que assumam, que falseiem ou ameacem falsear a concorrência, favorecendo certas empresas ou certas produções".

De um modo genérico os auxílios de Estado são proibidos quando impliquem a verificação de quatro condições cumulativas:

- Uma vantagem para os sujeitos passivos a quem se aplica a medida;

- A vantagem seja concedida através de recursos estatais;

- A vantagem afete a concorrência e as trocas comerciais entre os EstadosMembros;

- A vantagem conferida seja específica e seletiva, favorecendo certas empresas ou certas produções.

A proibição dos auxílios de Estado serve o duplo propósito de evitar, por um lado, o desperdício de recursos públicos através da concessão de subsídios que podem ser ineficientes e, por outro, que investimentos eficientes assumam posições dominantes pondo em causa um mercado interno competitivo e aberto.

\section{Aplicação da proibição dos auxílios de Estado em matérias fiscais}

Foi essencialmente a partir de 1998, através de uma comunicação ${ }^{1}$, que a Comissão, órgão executivo com competência para determinar se um auxílio em concreto é ou não compatível com o mercado interno, começou a aplicar as disposições dos auxílios de Estado aos apoios fiscais. Essa comunicação tinha como objetivo fazer clarificações

\footnotetext{
1 "Comunicação da Comissão sobre a aplicação das regras relativas aos auxílios estatais às medidas que respeitam à fiscalidade directa das empresas”, JO 98/C, 384/03, de 10 de dezembro de 1998.
} 
acerca quer do tipo de medidas que poderiam ser consideradas como auxílios de Estado, quer das consequências que poderiam resultar daí . A ação da Direção-Geral da Concorrência na área da tributação direta é, portanto, relativamente recente, e um assunto, como veremos, não totalmente pacífico.

Esta nova prática apoiou-se não só no artigo 107, n. ${ }^{\circ} 1$ do TFUE, mas também em vários instrumentos de soft law, como comunicações, notas e outros instrumentos não vinculativos.

No contexto destes instrumentos destaca-se o Código de Conduta sobre Tributação de Sociedades ${ }^{3}$ adotado pelo Conselho de Ministros de Economia e Finanças (ECOFIN). Este código de conduta, tal como outros instrumentos de soft law, não é vinculativo, mas expressa, ainda assim, um compromisso político feito pelos Estados-Membros. Este código refere-se a todas as medidas que possam afetar de forma significativa a localização de uma atividade comercial, incluindo a desenvolvida por grupos de sociedades, independentemente da forma que assumam, sejam leis, regulamentos ou práticas administrativas ${ }^{4}$. Exemplos de medidas com esse efeito são aquelas que implicam uma redução da tributação ou até uma isenção, tendo como referência os níveis de tributação que se aplicam normalmente nos Estados em causa.

Por ocasião do momento em que se determina se as medidas tomadas têm ou não uma natureza negativa, considera-se, por exemplo:

- Se as vantagens são unicamente conferidas a não residentes ou a operações envolvendo não residentes;

- Se as medidas são preparadas de modo a não ter efeitos na base tributária nacional;

- Se as vantagens são conferidas mesmo em situações em que não há uma atividade económica real;

- Se na atribuição das vantagens são desconsiderados os princípios de direito fiscal internacional designadamente os aprovados no âmbito da OCDE;

- Se existe falta de transparência na atribuição de vantagens.

\footnotetext{
2 "Comunicação da Comissão", JO 98/C 384/03, 3-9, parág. 24-25, 27.

${ }^{3} \mathrm{JO}$ C $2 / 2$, de 6 de janeiro de 1998, 2-5.

${ }^{4}$ JO C 2/2, 2-5, parág. A.
} 
Verifica-se, portanto, que o código de conduta constitui uma base importante para que os Estados se comprometam a não introduzir medidas potencialmente nocivas e a reavaliar as existentes.

Porém, e no sentido de assegurar que, na consideração das medidas tomadas, estaria um instrumento vinculativo, a Comissão comprometeu-se a avaliar as questões de concorrência prejudicial à luz das regras dos auxilios de Estado. Nesse contexto, e para assegurar previsibilidade a nível das decisões e um tratamento igualitário, a Comissão comprometeu-se a publicar linhas orientadoras relativas à aplicação das regras sobre auxílios de Estado quando estivessem em causa medidas com impacto na tributação direta que incidisse sobre sociedades ${ }^{5}$ tendo para isso produzido a comunicação a que já aludimos ${ }^{6}$.

Essa comunicação prescreve, relativamente à relação entre o Código de Conduta e a proibição de auxílios de Estado, que "A qualificaşão de uma medida fiscal como prejudicial no contexto do código de conduta não afeta a possibilidade de qualificar uma determinada medida como sendo um Auxílio de Estado"'. Todavia, a determinação da compatibilidade da medida (considerada auxílio de Estado) com o mercado comum tem de ter em conta os efeitos dos auxílios no âmbito do código de conduta.

Em fevereiro de 2004, a Comissão fez um relatório (em 9 de fevereiro de 2004) sobre a implementação dessa comunicação ${ }^{8}$, de onde decorrem ilações importantes no que respeita à clarificação da prática da Comissão que concerne à aplicação da proibição dos auxílios de Estado à tributação direta dos lucros empresariais.

De salientar, por fim, que em 2009 é dado um novo impulso a estas matérias através de uma Comunicação que tinha em vista promover uma boa administração em matérias fiscais ${ }^{9}$. Sendo a boa administração (ou governança) aí definida como cooperação internacional a nível fiscal para promover referências comuns em termos de transparência, troca de informações e uma equilibrada concorrência fiscal ${ }^{10}$.

\footnotetext{
${ }^{5}$ COM (97) 459 final, outubro 1997, parág. 17.

6 "Comunicação da Comissão", JO C 384.

7 “Comunicação da Comissão", JO C 384, 3-9, parág. 30.

${ }^{8} \mathrm{C}(2004) 434$, de 9 de fevereiro de 2004.

${ }^{9}$ COM (2009) 201 final, de 28 abril de 2009.

${ }^{10}$ Cfr. Manuel Fontaine Campos, "O Controlo da Concessão de Ajudas Públicas na União Europeia e na Organização mundial do Comércio - Fundamentos, Regimes e Resolução de Desconformidades”
} 


\section{Ponto de viragem}

Durante 2014 houve uma fuga de informação relativa a várias centenas de informações prévias (vinculativas) feitas pelas autoridades fiscais do Luxemburgo (Luxembourg Leaks). Esta fuga representou o culminar de uma investigação feita por uma rede de jornalistas que teve como consequência a imputação às autoridades Luxemburguesas da responsabilidade de terem ajudado multinacionais a evitar o pagamento de impostos em outros sistemas legais.

Mais recentemente, surgiram outros casos do mesmo teor dignos de nota, envolvendo as autoridades fiscais da Irlanda (Apple); da Holanda (Starbucks) e do Luxemburgo (Fiat, Amazon e mais recentemente a McDonalds). No caso específico da Apple, a Comissão, através da Comissária Margrethe Vestager, ordenou em agosto de 2016, à Irlanda que recuperasse 13 mil milhões de Euros de impostos ${ }^{11}$.

\section{Relação com as liberdades económicas fundamentais}

Também a proibição dos auxílios de Estado, tal como as liberdades de circulação, tem em vista assegurar uma livre concorrência no mercado interno e que este não sofra distorções.

O modo de funcionamento é, todavia, diferente. As liberdades têm em vista a remoção de barreiras à liberdade de circulação de serviços, mercadorias, capital e pessoas. A proibição dos auxílios de Estado, por sua vez, têm em vista assegurar que os Estados não atribuam vantagens seletivas a certas operações em detrimento de outras.

É muito importante salientar que o âmbito da proibição dos auxílios de Estado é muito mais alargado do que o das liberdades económicas fundamentais. Por um

(Tese apresentada à Universidade Católica Portuguesa para obtenção do Grau de Doutor em Direito, Porto: policopiada, 2011), 407-409.

${ }^{11}$ Cfr. Simon Bowers, "Apple and Ireland will fight the EU's $€ 13 b n$ tax ruling all the way", The Guardian, 19 de dezembro de 2016, https://www.theguardian.com/business/2016/dec/19/apple-ireland-eu-taxruling-european-commission-us-irs. 
lado, as liberdades aplicam-se unicamente a situações transfronteiriças, podendo os Auxílios aplicar-se a situações puramente internas. Para além do mais, enquanto as liberdades fundamentais proíbem a discriminação de não-residentes, os auxílios de Estado proíbem qualquer forma de discriminação que envolva a atribuição de uma vantagem a um determinado tipo de operações.

Na prática, podemos ser confrontados com aquilo a que certa doutrina chama infração paralela ${ }^{12}$. Isto porque, pelo facto de uma determinada medida ser considerada como constituindo um auxílio de Estado não invalida que se considere também como violando as liberdades económicas fundamentais. $\mathrm{O}$ que, aliás, é reconhecido pelo Tribunal de Justiça (TJ) ${ }^{13}$ que, nesse contexto, afirma expressamente que a Comissão não pode declarar que um determinado auxílio é compatível com o mercado interno se isso implicar uma violação de uma das liberdades fundamentais ${ }^{14}$. O TJ firmou, no entanto, uma orientação no sentido de que quando as medidas a considerar estiverem tão indissoluvelmente ligadas ao objeto do auxílio que não seja possível apreciá-las isoladamente, não podem ser apreciadas no contexto das liberdades económicas fundamentais ${ }^{15}$. Ora, isto implica, necessariamente, que antes de ser analisada uma determinada medida sob a perspetiva das liberdades económicas fundamentais seja, portanto, preciso verificar primeiro se é possível fazer a dissociação entre essas medidas e o objeto do auxílio.

O caso Sardegna ${ }^{16}$ é um bom exemplo de aplicação simultânea dos auxílios de Estado e das liberdades económicas fundamentais. Este caso tem a ver com a criação de um imposto ambiental a incidir sobre navios e aeronaves que fizessem escala na Sardenha, ficando isentas as embarcações detidas e operadas por pessoas aí residentes.

\footnotetext{
${ }^{12}$ Cfr. Marie-Ann Kronthaler, Yinon Tzubery, “The State Aid Provisions of the TFEU in Tax Matters",

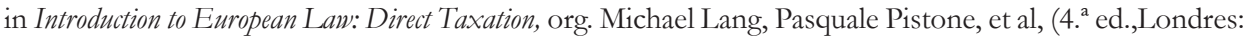
Spiramus, 2016), 103.

${ }^{13}$ Cfr. acórdão TJUE de 22 de março de 1977, Lanelli \& Volpi SpA v. Ditta Paolo Meroni, Processo C-74/76, ECLI:EU:C:1977:51, n. ${ }^{\circ} 9$.

${ }^{14}$ Cfr. acórdão TJUE de 15 de abril de 2008, Nuova Agricast Srl v. Ministero delle Attività Produttive, Processo C-390/06, ECLI:EU:C:2008:224, n. ${ }^{\circ} 50$.

${ }^{15}$ Cfr. acórdão Lanelli er Volpi SpA v. Ditta Paolo Meroni, n. ${ }^{\circ} 14$.

${ }^{16}$ Acórdão TJUE de 17 de novembro de 2009, Sardegna, Processo C-169/08, ECLI:EU:C:2009:709.
} 
O TJ concluiu que uma legislação fiscal como a que estava em causa constituía quer uma restrição à livre prestação de serviços - na medida em que onerava unicamente os operadores que exploram aeronaves destinadas ao transporte privado de pessoas e barcos de recreio, com domićlio fiscal fora do território regional, sem sujeitar ao mesmo imposto os operadores estabelecidos naquele território - quer um auxílio de Estado a favor das empresas estabelecidas na Sardenha ${ }^{17}$.

A violação simultânea das disposições sobre os auxílios de Estado e das liberdades económicas fundamentais gera problemas de difícil solução, pois, quando um auxílio de Estado não tem justificação, o montante em que se traduz a vantagem deve ser restituído pelo sujeito passivo com juros, à taxa definida pela Comissão ${ }^{18}$. Ao mesmo tempo, porém, os sujeitos passivos que foram afetados pela infração (discriminados) têm direito a ser reembolsados. Verificar-se-á, por conseguinte, uma inversão da discriminação o que se apresenta como imensamente problemático.

Apesar da sua importância, o caso Sardegna deixou este problema por resolver. O que se justifica pelo facto de o reenvio ter sido feito pelo Tribunal Constitucional Italiano, e, por conseguinte, a questão ter sido apreciada no plano puramente abstrato.

Entendemos, porém, que apesar de sob o ponto de vista do Direito da União Europeia ser indiferente existir uma recuperação do auxílio ou um reembolso do imposto indevidamente pago, nestas situações, a recuperação do auxílio terá vantagens, devendo, por isso, ser privilegiada. Até porque resolveria simultaneamente o problema dos auxílios e o da violação das liberdades de circulação.

Aliás, o reembolso do imposto pago indevidamente teria apenas como consequência generalizar, o auxílio, deixando de fora os residentes que fossem eventualmente discriminados e que, nesse enquadramento, poderiam ficar desprotegidos. Depois, além de manter a discriminação de residentes que pudessem ser eventualmente discriminados, a solução de reembolso, em termos financeiros, poderia ser problemática para o Estado em causa ${ }^{19}$, dado que envolveria consideráveis despesas.

\footnotetext{
${ }^{17}$ Cfr. acórdão Sardegna, 35-38, 62-64.

${ }^{18}$ Art. 14. ${ }^{\circ}$ do Regulamento (CE) 659/1999.

${ }^{19}$ Cfr. Mélanie Staes, "The Combined Application of the Fundamental Freedoms and the EU State Rules: In Search of a Way Out of the Maze", Intertax 42, 2 (2014): 119.
} 
Não obstante a opinião expressa, é óbvio que cabe ao Estado-Membro envolvido a decisão acerca de qual das soluções deve aplicar.

\section{Desafios}

O caso McDonald's é um dos exemplos mais recentes e exemplificativos de como a Comissão Europeia está a tentar combater as disparidades entre legislações através dos auxílios de Estado. Resumidamente, no contexto deste caso, a Comissão Europeia iniciou uma investigação formal sobre o tratamento fiscal da McDonald's no Luxemburgo, tendo concluído, na sequência de uma análise preliminar, que um acordo fiscal prévio pode ter concedido à McDonald's um tratamento fiscal favorável em violação da legislação da UE em matéria de auxílios estatais. A Comissão tentará verificar, na decorrência do procedimento de investigação, se as autoridades luxemburguesas aplicaram uma derrogação seletiva das disposições da sua legislação nacional em matéria fiscal e da convenção de dupla tributação celebrada entre o Luxemburgo e os EUA, concedendo, assim, à McDonald's, uma vantagem não conferida às outras empresas em situação factual e jurídica comparável ${ }^{20}$.

Entendemos que em casos como aquele a que acabámos de aludir, a solução para as disparidades, até porque não são imputáveis a um Estado individualmente considerado, passa por legislação que promova uma harmonização e não pela aplicação dos auxílios de Estado ${ }^{21}$. Até porque a aplicação destes, naquelas situações, pode implicar que a Comissão choque com a soberania fiscal dos Estados e a liberdade que estes têm de celebrar tratados, neste momento pacífica ${ }^{22}$.

A ação da comissão na área dos auxílios de Estado aplicados à tributação direta

\footnotetext{
${ }^{20}$ Cfr. "Auxílios estatais: Comissão dá início a uma investigação formal sobre o tratamento fiscal da McDonald's no Luxemburgo", Comissão Europeia - Comunicado de imprensa, 3 de dezembro de 2015, http://europa.eu/rapid/press-release_IP-15-6221_pt.htm.

${ }^{21}$ Cfr. Daniel S. Smit, "International Juridical Double Non.-Taxation and State Aid", EC Tax Review, 2 (2016): 109-112.

${ }^{22}$ Cfr. acórdão TJUE de 5 de julho de 2005, D, Processo C-376/03, ECLI:EU:C:2005:424. No passado existiam dúvidas. Ver, a este propósito, Raymond Luja, "Tax Treaties and State Aid: Some Thoughts", European Taxation, 44, 5 (2004): 234-238.
} 
suscita também a dúvida de saber se a Comissão terá capacidade e recursos para analisar tanta informação. Só em 2015, como já foi aludido, solicitou informação acerca de informações prévias a mais de 15 países, tendo, além disso, pedido a todos os Estados-membros para reportarem as informações prévias dadas entre 2010 e $2013^{23}$, tendo ainda iniciado uma investigação acerca de 165 informações prévias dadas por Gibraltar ${ }^{24}$.

O recurso demasiado frequente ao expediente dos auxílios de Estado pode gerar problemas a nível da articulação entre a competência dos Estados Membros e da União Europeia, identificados já na decisão do Tribunal Geral, no acórdão Banco Santander ${ }^{25}$, e retomados de forma magistral pela Advogada Geral Kokott na opinião referente ao caso Finanz $\operatorname{Linz}^{26}$, que não resistimos a transcrever:

" [U]m entendimento demasiado amplo da seletividade de regimes nacionais implica o risco de afetar a repartição das competências entre os Estados-Membros e a União, estabelecida nos artigos $2 .^{\circ}$ a $60^{\circ}$ TFUE, bem como a repartição das competências, na União, entre o Parlamento Europeu e o Conselho, nos termos do artigo 14. ${ }^{\circ}$ TFUE, por um lado, e a Comissão, nos termos do artigo 17. ${ }^{\circ}$ TFUE, por outro. Com efeito, face a um auxílio na aceção do artigo $107 .{ }^{\circ}, n .^{\circ} 1$, TFUE, a Comissão dispõe em regra, nos termos do artigo $107 .^{\circ}, n .^{\circ} 3$, TFUE, de uma ampla margem de manobra para apreciar se, e em que condições, apoia ou não as decisões políticas tomadas pelos Estados-Membros, sem que os Tratados the atribuam um poder normativo autónomo nos domínios políticos em causa.

Contudo, particularmente em direito fiscal, o caráter seletivo de um regime é o critério decisivo, porque os restantes requisitos do artigo 107. ${ }^{\circ},{ }^{\circ}{ }^{\circ}$, TFUE se verificam quase sempre. Assim, segundo jurisprudência assente, não épreciso provar uma efetiva distorção da concorrência pelo auxilio em causa nem qualquer incidência efetiva sobre as trocas comerciais entre os Estados-Membros, mas

\footnotetext{
${ }^{23}$ Cfr. "State aid: Commission extends information enquiry on tax rulings practice to all Member States", , Comissão Europeia - Comunicado de imprensa, 17 de dezembro de 2014, http://europa.eu/rapid/ press-release_IP-14-2742_en.htm.

${ }^{24}$ Cfr. "State aid: Commission extends in-depth investigation into Gibraltar corporate tax regime to include tax rulings practice", Comissão Europeia - Comunicado de imprensa, 1 de outubro de 2014, http:// europa.eu/rapid/press-release_IP-14-1073_en.htm.

${ }^{25}$ Acórdão Banco Santander, de 7 de novembro de 2014, Processo T- 399/11, ECLI:EU:T:2014:938.

${ }^{26}$ Acórdão Finanz Lin₹, de 16 de abril de 2015, Processo C-66/14, ECLI:EU:C:2015:661.
} 
apenas examinar se o auxilio é suscetivel de falsear a concorrência e afetar as trocas comerciais entre os Estados-Membros ${ }^{27}$. Nem é necessário que as empresas favorecidas participem, elas próprias, nas trocas comerciais entre os Estados-Membros, sendo suficiente que o possam fazer no futuro ou que as suas concorrentes estrangeiras possam tentar expandir-se no mercado nacionalp.

Por conseguinte, há que utilizar com cuidado o critério da seletividade de um regime nacional. Se o regime não afeta um ou mais sectores concretos identificáveis que possam delimitar-se pela sua atividade económica, nem empresas identificáveis individualmente, como exige o teor do artigo $107 .^{\circ}$, $n .^{\circ} 1$, TFUE, não se pode, em princípio, considerar que o regime tem caráter seletivo" 29 .

Para além dos problemas no seio da União levantam-se questões também a nível da relação com países terceiros, designadamente com os EUA de onde são provenientes uma grande parte das empresas tecnológicas sujeitas a investigação. Sendo também fonte de dificuldades a articulação das regras europeias relativas aos auxílios de Estado com as regras congéneres na Organização Mundial do Comércio que, apesar de alguma proximidade, não são imunes a alguns problemas de conciliação de regimes ${ }^{30}$. Para não falar dos danos de reputação para essas empresas, dado que na sequência destas investigações, domina neste momento a ideia de que toda e qualquer informação prévia ou acordo a nível dos preços de transferência se traduz num auxílio de Estado.

Esta questão é particularmente grave pelo facto de as questões sujeitas a investigação terem essencialmente a ver com preços de transferência ${ }^{31}$ que, pela natureza especialmente complexa e indeterminada de muitas das suas disposições,

\footnotetext{
${ }^{27}$ Cfr., designadamente, os acórdãos TJUE de 29 de abril de 2004, Itália/ Comissão, Processo C-372/97, ECLI:EU:C:2004:23, n. ${ }^{\circ}$ 44, de 8 de setembro de 2011, Paint Graphos e o, Processos C-78/08 a C-80/08., ECLI:EU:C:2011:550, n. 78 e de 14 de janeiro de 2015, Eventech, Processo C-518/13, ECLI:EU:C:2015:9, n. ${ }^{\circ} 65$.

${ }^{28}$ Cfr. o acórdão TJUE de 10 de janeiro de 2006, Cassa di Risparmio di Firenze e o, Processo C-222/04, ECLI:EU:C:2006:8, n. ${ }^{\circ}$ 143, bem como o acórdão Paint Graphos e o., n. ${ }^{\circ} 80$.

${ }^{29}$ Acórdão Finanz Linz, no. ${ }^{\text {os } 113-115 . ~}$

${ }^{30}$ Cfr. Pernille Wegener Jessen, "State Aid and Taxation in Relation with Third Countries", Intertax, 40, 2 (2012): 132-138; Laura Allevi, Chiara Celesti, "10 $0^{\text {th }}$ GREIT Annual Conference on EU BEPS; Fiscal Transparency, Protection of Taxpayer Rights and STATE Aid and $7^{\text {th }}$ GREIT Summer Course on Tax Evasion, Tax Avoidance \& Aggressive Tax Planning", Intertax, 44, 1 (2016): 83.

${ }^{31}$ Cfr. Eduard Sporken \& Yves Cattel, "Investigations by European Commission into Transfer Pricing Underlying Certain Tax Rulings in the European Union", International Transfer Pricing Journal, maio/junho (2015): 131-140.
} 
se prestam a inúmeras interpretações. Ora, é precisamente essa circunstância que faz com que os acordos e informações prévias sejam especialmente procurados pelas multinacionais, para conseguirem ter alguma certeza jurídica.

Este enquadramento aconselharia a que essas questões, principalmente as ligadas aos preços de transferência, não fossem apreciadas no âmbito dos auxílios de Estado. É um terreno movediço aquele em que atua, neste momento, a Comissão, pois não é de modo algum claro onde determinado acordo ou informação prévia está meramente a interpretar a lei ou desviar-se da aplicação normal de uma determinada disposição. Isso sem esquecer que os acordos e informações prévias fazem claramente parte da competência dos Estados-Membros, sendo uma expressão da sua soberania $\mathrm{Fiscal}^{32}$. Além do mais, existe a possibilidade de os Estados recorrerem, para resolver esse tipo de diferendos, a um procedimento amigável, no domínio da OCDE, ou à Convenção de arbitragem ${ }^{33}$, no seio da União Europeia.

Os excessos da Comissão verificam-se, por exemplo, no facto de substituir, inclusive, o há muito consolidado princípio da independência aplicável em matéria de preços de transferência pela OCDE por um conceito vago, e muito menos elaborado, de operador de mercado prudente e independente (prudent independent market operator). Ora, esta substituição tem como efeitos maximizar a incerteza e indeterminação ${ }^{34}$.

Julgamos que existem outros meios muito mais eficientes para conseguir uma harmonização do que o uso do mecanismo dos auxilios de Estado. Destacamos, a este propósito desenvolvimentos como, por exemplo, o estabelecimento de regras contra as práticas de elisão fiscal que tenham incidência direta no funcionamento do mercado interno ${ }^{35}$; a troca automática de informações; o relançamento da matéria coletável comum consolidada do imposto sobre as sociedades (MCCCIS); entre outros mecanismos, o que aconselha, por conseguinte, a alguma contenção no uso dos auxílios de Estado.

\footnotetext{
${ }^{32}$ Cfr. Raymond H. C. Luja, "(Re)shaping Fiscal State Aid: Selected Recent Cases and Their Impact", Intertax, 40, 2 (2012): 120-131.

${ }^{33}$ Convenção 90/463/CEE, de 20 de agosto de 1990.

${ }^{34}$ Cfr. Luc de Broe, "The State Aid Review against Aggressive Tax Planning: 'Always Look a Gift Horse in the Mouth”, EC Tax Review, 6 (2015): 291.

${ }^{35}$ Diretiva (UE) 2016/1164 do Conselho, de 12 de julho de 2016, que estabelece regras contra as práticas de elisão fiscal que tenham incidência direta no funcionamento do mercado interno.
} 



\title{
Ponderações sucintas sobre despesa pública e sustentabilidade financeira nos ordenamentos brasileiro e português
}

\author{
Joaquim Freitas da Rocha*
}

RESUMO: An entity's finances are sustainable if the entity is both able to fulfil the generality of obligations it previously assumed and also demonstrate that it is capable of assuming new obligations. The obligation of maintaining assumed commitments is related with the issue of assure positive rights of economic, social, and cultural nature. In this regard it is frequent to question if there are really "acquired rights" and if it is possible to positively assert the existence of a binding principle banning social regression. Notwithstanding the fact that the constitutional jurisprudence of several legal orders states that this principle does not exist in absolute and intangible terms (something that is reinforced by the Brazilian constitutional amendment $n .{ }^{\circ} 95$ and by the restrictive policies resulting from the impositions by Troika), it is acknowledged that there is, with binding force, an obligation of protecting the legitimate expectations acquired by the beneficiaries of social benefits.

PALAV RAS-CHAVE: finanças públicas - despesa pública - sustentabilidade financeira - equidade intergeracional - retrocesso social.

ABSTRACT: An entity's finances are sustainable if the entity is both able to fulfil the generality of obligations it previously assumed and also demonstrate that it is capable of assuming new obligations caused by the natural evolution of affairs. The obligation of maintaining assumed commitments centres its discourse on the issue of upholding positive rights of economic, social, and cultural nature. In this regard it is frequent to question if there are really "acquired rights" and if it is possible to positively assert the existence of a binding principle banning social regression. Notwithstanding the fact that the constitutional jurisprudence of several legal orders states that this principle does not exist in absolute and intangible terms (something that is reinforced by the constitutional amendment $n .{ }^{\circ} 95$ and by the restrictive policies resulting from the impositions by Troika), it is acknowledged that there is, with binding force, an obligation of protecting the legitimate expectations acquired by the beneficiaries of social benefits.

KEYWORDS: public finances - public spending - financial sustainability - intergenerational equity - social regression.

* Diretor do Mestrado em Direito Tributário da Universidade do Minho. Membro Doutorado do Centro de Estudos em Direito da União Europeia - CEDU. 


\section{I.}

A consideração estratificada ou multinível de um determinado arranjo jurídico institucional (baseado ou não da ideia de Estado) não dispensa a abordagem das dimensões financeiras e dos correspondentes nexos relacionais que no âmbito do mesmo se podem estabelecer. Na verdade, dir-se-á que tão importante quanto as dimensões organizatória (qual o aparato de órgãos legiferantes e aplicativos que se considera relevante), democrático-legitimatória (quais os esquemas de eleição e participação que os cidadãos em geral podem utilizar) ou material (quais as garantias de justiça substantiva e adjetiva que existem ao dispor dos interessados), será a dimensão jurídico-financeira, contendo as questões inerentes aos dinheiros públicos, particularmente aos seus modos de obtenção e utilização.

Nesta medida, num evento sobre cruzamentos jurídico-normativos e internormatividade não será despropositado trazer ao discurso a temática do Direito financeiro público, numa perspetiva abrangente, cuidando de refletir sobre os inerentes esquemas relacionais que se podem perspetivar entre sujeitos integrados em ordenamentos compostos, particularmente no quadro de arranjos caracterizados pela complexidade, como o são os ordenamentos federais ou o ordenamento da União Europeia (UE).

Sendo verdade que abstratamente muitos problemas poderiam ser considerados, nas presentes ponderações dois serão objeto de particular atenção e reflexão: por um lado, (i) a ideia de sustentabilidade do sistema financeiro e, por outro lado, (ii) a compatibilização dessa sustentabilidade com a tutela das legítimas expectativas dos destinatários das atuações públicas, especificamente das atuações sociais.

Antecipa-se que serão reflexões muito breves e concisas, e apenas se terá em vista a sustentabilidade numa perspetiva financeira, embora não possa ser descurado que o mesmo predicado pode e deve ser tematizado sob variados outros pontos de vista (ambiental, social, político, económico, etc.). 


\section{II.}

A primeira grande ideia a reter é a de que contas equilibradas não é sinónimo necessariamente de contas estabilizadas nem, muito menos, de contas sustentáveis. Não sendo este o local nem a colocação discursiva certa para efetuar aprofundamentos conceituais que se revelariam desapropriados ${ }^{1}$, sempre se pode adiantar que genericamente o equilíbrio das contas públicas convoca uma ideia de localização temporal determinada, reportada a um exercício financeiro (um ano) e, consequentemente, a um orçamento determinado. Diferentemente, a estabilidade já convoca uma ideia de plurianualidade e de ultrapassagem do concreto período financeiro, envolvendo nessa medida uma apreciação de médio prazo. Assim, as contas estabilizadas (não necessariamente coincidentes com as contas "estáveis") serão aquelas que, mesmo que eventualmente deficitárias num concreto exercício, conseguem demonstrar que, nos exercícios seguintes, é possível reverter a patologia - e o défice é, para todos os efeitos, uma patologia - e alinhar numa demonstração de resultados positivos.

De resto, até será este o enfoque que ressalta do enquadramento jurídiconormativo da UE, no âmbito do qual não se pró́be liminarmente o défice das contas públicas, mas apenas se pró́be a sua existência quando o mesmo se revelar "excessivo", atendendo a determinados critérios pré-definidos e pré-determinados (nos termos do art. $126 .^{\circ}$ do TFUE) ${ }^{2}$.

Já a sustentabilidade não se reporta diretamente às contas públicas - pelo que não será rigorosamente adequado falar em "contas sustentáveis" -, mas ao arranjo institucional a que as mesmas dizem respeito. Por outras palavras: enquanto o equilíbrio e a estabilidade serão um predicado das partes (das contas, do orçamento,

\footnotetext{
${ }^{1}$ Cfr., a propósito, o nosso “Autonomia e sustentabilidade financeira das autarquias locais”, Dereito: Revista Xurídica da Universidade de Santiago de Compostela 25 (2016): 159 e ss.

${ }^{2}$ Para a consideração do carácter excessivo do défice público no quadro do arranjo jurídico-financeiro da construção europeia, v. o nosso "A solidez das finanças públicas estaduais e o Direito da União europeia. Em particular, o pacto de estabilidade e crescimento e o procedimento relativo a défices excessivos", in Direito da União Europeia e Transnacionalidade: Aç̧ão Jean Monnet (Information and Research Activities), coord. Alessandra Silveira (Lisboa: Quid Iuris, 2010), 145 e ss.
} 
etc.), a sustentabilidade será um predicado do todo (as finanças). O que será, ou não, sustentável será o arranjo jurídico-financeiro, o sistema financeiro público, do qual as contas constituem apenas uma parcela de apreciação, ao lado de outras parcelas.

\section{III.}

A verdade é que não é fácil definir sustentabilidade ou, em modo menos ambicioso, precisar os seus contornos, tratando-se de um conceito extremamente amplo, além de plurissignificativo. Numa tarefa de aproximação, entende-se que um determinado sistema será sustentável quando se afirmar suscetível de manutenção em termos de não retrocesso significativo. Significa isto que a noção de sustentabilidade convoca várias coordenadas distintas, a saber: (i) a transtemporalidade, na medida em se apela à ideia de manutenção temporal e de ultrapassagem do concreto momento em que se existe (e já não, como supra, à localização num certo ano ou simplesmente nos anos próximos); e (ii) a manutenção da identidade, uma vez que só se pode afirmar sustentável o que, sendo o que é, continua a ser aquilo que já era, antes do decurso de um lapso de tempo alargado. Logo, não será sustentável aquela realidade que não consegue persistir no tempo, nem aquela que, persistindo, perdeu traços significativos da sua identidade ou em que estes se apresentam manifestamente desvirtuados. Por exemplo, uma instituição não será sustentável se é possível adiantar que em alguns anos deixará de existir ou apenas conseguirá afirmar a sua existência se perder algumas das características essenciais que atualmente detém. Localizando ainda mais o discurso: não serão sustentáveis as finanças públicas de um Estado ou de um ordenamento se, mantendo-se as atuais condições (v.g., o mesmo nível qualitativo e quantitativo de receita, a mesma produtividade, a mesma eficiência administrativa), se demonstra que não é possível manter o nível de despesa pública e de prestações que o mesmo vinha dispensado em termos regulares.

Nesta medida, e como está fácil de ver, o predicado da sustentabilidade surge frequentemente associado a realidades institucionais, como o Estado, a família, a 
igreja, o mercado, etc., embora não seja desacertado a utilização do termo como predicativo de determinada realidade não institucional.

Enfim, e em termos gerais, aquela instituição que com o tempo vai perdendo as suas características essenciais não se pode afirmar sustentável, pois na verdade tornase em algo diferente daquilo que originariamente era.

\section{IV.}

Ora, partindo do pressuposto de que as coisas se podem assim conceber, as finanças de determinado ente serão sustentáveis se este último consegue fazer face à generalidade dos encargos que já assumiu e demonstra estar apto a assumir responsavelmente novos encargos decorrentes da evolução normal das coisas. De um modo mais específico, é possível dizer-se que um sistema financeiro público será sustentável se o atual nível prestacional pode ser mantido sem alteração dos seus traços significativos e essenciais, seja ao nível das receitas - poderá ser mantido com o mesmo manancial de recursos ou com um manancial equiparado - seja ao nível das despesas - poderá ser mantido sem restrições e cortes excessivos ou retrocesso (social) intolerável ${ }^{3}$.

Nesta perspetiva, a sustentabilidade de um sistema financeiro público encontrase estreitamente conexionada com o denominado princípio da equidade intergeracional, num duplo sentido garantístico:

Em primeiro lugar, tendo por referência o passado (garantia de manutenção), procurando significar que o atual sistema é capaz de respeitar os compromissos assumidos pelas anteriores gerações e as obrigações e os deveres que dos mesmos resultam. Aqui, relevam essencialmente os compromissos assumidos em sede de Direito da União Europeia (por exemplo, cumprimento de imposições em matéria

\footnotetext{
${ }^{3}$ Num certo sentido, a lei de enquadramento orçamental portuguesa (Lei n. ${ }^{\circ}$ 151/2015) adota em enfoque alinhado com o referido no texto ao prescrever (art. $1 .^{\circ}$ ) que a sustentabilidade consiste na capacidade de financiar todos compromissos, assumidos ou a assumir, com respeito pela regra do saldo orçamental estrutural e da dívida pública.
} 
de políticas comunitárias ou de coordenação das finanças dos Estados-membros), de Direito internacional público (como os deveres decorrentes de missões de paz, de financiamento de organizações internacionais ou de protocolos de cooperação), de contratação pública em geral (designadamente em domínios concessionais ou de parceria público-privado) e de prestações sociais (cuidados de saúde, fornecimento de refeições escolares, ajudas a idosos, proteção de crianças e jovens em risco, etc.);

Em segundo lugar, tendo por referência o futuro (garantia de continuidade), demonstrando que o mesmo é capaz de manter a longo prazo, em termos equivalentes, o atual nível de utilidades e prestações.

Ora, o sistema que não consiga atualmente cumprir com os compromissos assumidos no passado ou assegurar a proteção das legítimas expectativas no futuro não é sustentável. Note-se que a qualificação de determinado sistema como "insustentável" não envolve necessariamente um juízo negativo ou uma componente de desvalor pode acontecer que o sistema assim seja considerado porque, na verdade, não pode ser de outro modo, atendendo, por exemplo, às bases irresponsáveis sobre as quais o mesmo foi construído.

\section{V.}

A obrigatoriedade de manutenção dos compromissos anteriormente assumidos como decorrência do princípio da equidade intergeracional e da sustentabilidade de um sistema de finanças públicas, torna possível centrar o discurso no âmbito da efetivação dos direitos positivos, de natureza económica, social e cultural, campo no qual é recorrente a questão de saber se existem "direitos adquiridos" e se é possível afirmar a existência de um princípio vinculativo de proibição do retrocesso social.

A questão assume uma relevância acrescida se for lembrado que um dos grandes argumentos para que não se possa renegociar livremente contratos públicoadministrativos, designadamente em forma de parceria, é o de que os co-contratantes que assumiram compromissos juntos do Estado e de outras entidades públicas não podem agora, a pretexto da crise e da sustentabilidade das finanças públicas, ver as 
suas legítimas expectativas afetadas, por via da diminuição das remunerações (rendas) a cuja perceção tenham eventualmente direito. Em termos simples: o Estado, mesmo em crise, não poderia tocar em remunerações já contratualizadas com determinadas empresas que se comprometeram a prosseguir finalidades de interesse público (como por exemplo, a gestão de infraestruturas aeroportuárias, a gestão de hospitais, a exploração de rodovias ou ferrovias, etc.), pois estas esperam que o Estado, como "pessoa de bem", cumpra os compromissos que assumiu.

Ora, assim sendo, cabe perguntar: e os compromissos assumidos, não junto de empresas com as quais se contratualizou a prossecução do Interesse público, mas junto dos cidadãos em geral? Também estes não terão direito à tutela das suas legítimas expectativas, esperando que as prestações que lhes foram "prometidas" sejam efetivamente realizadas?

Não será este o local certo para a resposta a esta questão, até porque tal resposta obrigará à consideração de coordenadas de conhecimento que não poderão ser aqui adequadamente desenvolvidas. Em todo o caso, existem duas notas fundamentais que não podem deixar de ser relevadas:

Em primeiro lugar, a jurisprudência constitucional de vários ordenamentos tem vindo a afirmar que não existe um estrito princípio constitucional de proibição do retrocesso ou de intangibilidade social, isto é, um princípio jurídico-constitucional com eficácia jurídico-normativa vinculativa, em termos de inconstitucionalizar eventuais soluções legislativas restritivas. Tal assim será não apenas por razões jurídico-financeiras (argumento da "reserva do possível" e da sustentabilidade do sistema financeiro público), mas igualmente por razões jurídico-democráticas (inadmissibilidade de vinculação absoluta do legislador futuro) ${ }^{4}$;

Em segundo lugar, e não obstante o acabado de referir, reconhece-se a existência, com eficácia vinculativa, de uma regra de obrigatoriedade de tutela das legítimas expectativas adquiridas por parte dos destinatários de prestações sociais.

\footnotetext{
${ }^{4}$ Sugere-se, por exemplo, BVerfGE 59, 231 (263) ("Freie Mitarbeiter", disponível em http://www. servat.unibe.ch/dfr/bv059231.html) :, onde se pode ler: "Das Sozialstaatsprinzip stellt also dem Staat eine Aufgabe, sagt aber nichts darüber, wie diese Aufgabe im einzelnen zu verwirklichen ist - wäre es anders, dann würde das Prinzip mit dem Prinzip der Demokratie in Widerspruch geraten (...)".
} 
A questão da tutela dessas legítimas expectativas assume acrescida importância se as mesmas têm por referente direitos e prestações sociais em contextos de crise, designadamente os inerentes à consecução dos imperativos da socialidade (Estado social) e do asseguramento de uma existência condigna. Na verdade, é precisamente nessas alturas que se coloca com maior relevo e premência a questão de saber se as políticas de austeridade e de contenção das despesas públicas são compatíveis com os deveres constitucionalmente impostos de efetivação de prestações materiais (e apenas destas aqui se cuida, não colocando o enfoque nas ditas prestaçoes jurídicas).

\section{VI.}

No quadro dos ordenamentos português e brasileiro tais questões não poderiam ser mais atual.

No âmbito deste último (ordenamento brasileiro), cumpre trazer ao discurso a emenda constitucional n. ${ }^{\circ}$ 95, a qual acrescentou vários artigos às disposições constitucionais transitórias, dando corpo ao "Novo Regime Fiscal no âmbito dos Orçamentos Fiscal e da Seguridade Social da União", que vigorará por vinte exercícios financeiros ${ }^{5}$. Trata-se, portanto, de um conjunto de disposições jurídicas com intencionalidade normativa de longo prazo.

Neste novo "regime fiscal" avultam significativas imposições de limite à despesa pública de natureza orgânico-funcional, vinculando os mais altos órgãos e cargos do Estado, e com materialização em verdadeiras proibições de aumento de encargos tendo por referência o exercício imediatamente anterior (em termos reais, isto é, com correção pela variação do índice nacional de preços ao consumidor). Por outras palavras: não se pode gastar mais do que aquilo que se gastou no ano anterior. Em caso de incumprimento dos limites impostos, aplicam-se determinadas medidas restritivas ao ente infrator, designadamente a proibição (vedação) de concessão de vantagens remuneratórias ou a impossibilidade de admissões de pessoal. Em qualquer caso, um

\footnotetext{
${ }^{5} \mathrm{O}$ respetivo texto encontra-se disponível em http://pesquisa.in.gov.br/imprensa/jsp/visualiza/index. jsp?data $=16 / 12 / 2016 \&$ jornal $=1 \&$ pagina $=2 \&$ total Arquivos $=368$.
} 
regime especial aplica-se em matéria serviços públicos de saúde e ensino. Significativa é a menção específica contida no art. 112., de acordo com o qual "As disposições introduzidas pelo Novo Regime Fiscal (...) não constituirão obrigação de pagamento futuro pela União ou direitos de outrem sobre o erário". Trata-se, bem entendido, de uma cláusula de aviso ou de alerta, no sentido de que não se devem entender aqui contidas promessas ou compromissos insuscetíveis de retrocesso.

No ordenamento português, ainda estão na memória as políticas restritivas decorrentes das imposições da Troikea (Fundo Monetário Internacional, Banco Central Europeu, Comissão Europeia), relativamente às quais o Tribunal constitucional se debruçou e concluiu, entre demais considerações, que as "reduções significativas, capaz̧es de gerarem ou acentuarem dificuldades de manutenção de práticas vivenciais e de satisfação de compromissos assumidos pelos cidadãos" não devem ser consideradas constitucionalmente inadmissíveis, tendo em vista a "conjuntura de absoluta excecionalidade, do ponto de vista da gestão financeira dos recursos públicos" que o país então atravessava. Neste contexto, entendeu-se que não se estaria em presença de uma mutação da ordem jurídica com que os destinatários das normas dela constantes não pudessem verdadeiramente contar, vistas as ponderosas razões de interesse público que motivaram a alteração legislativa operada ${ }^{6}$.

Deste modo, parece inegável, num ordenamento e no outro, a não existência de uma cláusula de imutabilidade ou de proibição do retrocesso social, embora de modo mais vincado no ordenamento português.

Por aqui terminamos, embora com a fundada convicção de que muito mais haveria a considerar e a refletir. Porém, fica a nota de que se está aqui em presença de tópicos problemáticos que merecem, a vários níveis, estudo e reflexão crítica.

O Estado de Direito e social merece-o.

\footnotetext{
${ }^{6}$ Cf. acórdão do Tribunal constitucional n. ${ }^{\circ}$ 187/2013.
} 



\title{
O solidarismo jurídico no constitucionalismo contemporâneo brasileiro: breves notas introdutórias
}

\author{
Jorge Renato dos Reis*/Aneline dos Santos Ziemann*
}

RESUMO: O presente texto teve como objetivo efetuar a análise do constitucionalismo contemporâneo brasileiro e do princípio constitucional da solidariedade. Inicialmente analisou-se o constitucionalismo contemporâneo brasileiro pós Constituição Federal de 1988, passando em seguida à análise do princípio da solidariedade com a verificação de situações práticas. Concluiu-se que o ordenamento jurídico se modifica conforme a estrutura principiológica disposta na normativa constitucional, razão pela qual o princípio jurídico da solidariedade de estende por todo o ordenamento jurídico brasileiro remodelando as relações jurídicas que passaram a ter como eixo fundamental a dignidade da pessoa humana.

PALAV RAS-CHAVE: solidarismo - Direito - Constituição-Brasil-dignidade.

ABSTRACT: This paper aimed to make the analysis of the Brazilian contemporary constitutionalism and the constitutional principle of solidarity. Initially, Brazilian contemporary constitutionalism was analyzed after the 1988 Federal Constitution, followed by an analysis of the principle of solidarity with the verification of practical situations. It was concluded that the legal system is modified according to the principle structure laid down in the constitutional law, which is why the legal principle of solidarity extends throughout the Brazilian legal system remodeling legal relationships that have as a fundamental axis the dignity of the buman person.

KEYWORDS: solidarism - law - Constitution - Brazil-dignity.

* Doutor pela Universidade do Vale do Rio dos Sinos - UNISINOS. Professor do Programa de PósGraduação em Direito da Universidade de Santa Cruz do Sul - UNISC.

** Doutoranda em Direito na Universidade de Santa Cruz do Sul - UNISC com bolsa CAPES/Prosup (Tipo II). Docente do curso de Direito da Universidade Regional Integrada do Alto Uruguai e das Missões - URI, São Luiz Gonzaga. 


\section{Introdução}

Há sempre um eixo fundamental que direciona a leitura e a interpretação dos institutos jurídicos. A depender do momento histórico, este eixo se modifica de maneira que a interpretação do ordenamento jurídico e de seus institutos varia conforme a dinâmica constitucional vigente em cada momento histórico.

Afinal, qual é a influência que a Constituição Federal brasileira exerce sobre a normativa infraconstitucional? E qual o papel desempenhado pelos princípios constitucionais? Em busca de respostas para tais questionamentos o presente texto pretende realizar uma abordagem do princípio constitucional da solidariedade como um marco no constitucionalismo contemporâneo brasileiro.

Com este objetivo, as linhas que se desenvolvem abaixo buscam demonstrar que, contemporaneamente, o Direito brasileiro exige uma leitura e uma compreensão que estejam em consonância com o solidarismo jurídico, uma forma não individualista e cooperativa de ler, de compreender e de aplicar o ordenamento jurídico.

\section{Constitucionalismo contemporâneo no Brasil}

Inicialmente, convém traçar alguns esboços em torno daquilo que se vem denominando de "constitucionalismo". Notadamente, a delimitação espacial fica por conta do cenário brasileiro. Temporalmente, delimita-se a abordagem aqui realizada entre o ano de 1988, ano de promulgação da Constituição Federal vigente no Brasil, e o corrente ano de 2016.

No Brasil vive-se sob a égide de um Estado Democrático de Direito ${ }^{1}$, o que significa dizer que Estado brasileiro se constrói sobre a fusão de duas ideias centrais, a de "constitucionalismo", ou seja, a concepção de que o Estado é limitado pelos direitos fundamentais, e a de "democracia" que pressupõe a vontade e soberania do povo

\footnotetext{
1 “Art. 1. A República Federativa do Brasil, formada pela união indissolúvel dos Esta- dos e Municípios e do Distrito Federal, constitui-se em Estado Democrático de Direito e tem como fundamentos: [...]”, Constituição Federal Brasileira, acesso em outubro 1, 2016, http://www.planalto.gov.br/ccivil_03/ constituicao/constituicaocompilado.htm.
} 
como elemento indissociável do Estado ${ }^{2}$. É possível destacar, portanto, como notas basilares do constitucionalismo brasileiro, a sua intrínseca relação com os direitos fundamentais e com a soberania popular.

Inclusive, a constituinte que culminou com a promulgação da Constituição Federal de 1988 foi um processo que contou com a participação de uma sociedade que estava superando mais de vinte anos de vivência de um regime autoritário ${ }^{3}$.

É importante mencionar, com relação à força normativa da Constituição que esta não pode ignorar suas condicionantes materiais, sociais e econômicas além de que, conforme criação de Konrad Hesse, o elemento essencial para que a Constituição se transforme em força viva é a "vontade de Constituição", ou seja, a vontade social de que as suas disposições sejam realmente efetivadas. Importa lembrar também, que mesmo existindo uma profunda "vontade de Constituição", invariavelmente existirão limites impostos pela realidade social à sua efetivação e é importante que o constituinte esteja atento a tais limites, não fazendo da efetividade constitucional um mero devaneio, o que poderia acabar por erodir a força normativa constitucional ${ }^{4}$.

Importa também destacar o papel que a principiologia constitucional desempenha no cenário da constitucionalização, especialmente no Estado Democrático de Direito e que se alia a esta busca pela efetividade das normas constitucionais, a partir da sua imprescindível conexão com a realidade social. Neste sentido: "Na passagem para o Estado Democrático de Direito, por sua vez̧ especialmente em face do recrudescimento da idéia dos direitos fundamentais e da noção de dignidade humana, a Constituição acaba, mais do que nunca, assumindo uma função principiológica, assentada em dispositivos de textura aberta, numa estrutura que permite uma aferição ampla de seus conteúdos na realidade cotidiana, isto é, em face da vida constitucional propriamente dita's.

\footnotetext{
2 "O Constitucionalismo Democrático No Brasil: Crônica De Um Sucesso Imprevisto", Luís Roberto Barroso, acesso em outubro 1, 2016, http://www.luisrobertobarroso.com.br/wp-content/themes/ LRB/pdf/constitucionalismo_democratico_brasil_cronica_um_sucesso_imprevisto.pdf, 01-02.

3 "O Constitucionalismo Democrático", Luís Roberto Barroso, 01-02.

${ }^{4}$ Daniel Sarmento, Direitos Fundamentais e Relações Privadas (2. ${ }^{a}$ ed. Rio de Janeiro: Lumen Juris, 2010).

${ }^{5}$ Mônia Clarissa Hennig Leal, Jurisdição Constitucional Aberta: reflexões sobre a legitimidade e os limites da jurisdição constitucional na ordem democrática uma abordagem a partir das teorias constitucionais alemã e norte-americana (Rio de Janeiro: Lumen Juris, 2007), 40.
} 
Percetível portanto que a efetividade das normas constitucionais nasce de sua necessária vinculação entre as duas disposições e a realidade social subjacente.

Nesta perspetiva, a totalidade do ambiente jurídico passa a ser revista pela principiologia constitucional. As constituições que seguem esta lógica possuem um caráter de "abertura", que por sua vez, demanda uma atividade de criação hermenêutica dos tribunais, que possuem a tarefa de definir a abrangência e os limites dos direitos abarcados pela normativa constitucional ${ }^{6}$.

Tarefa esta que se pode ver sendo exercida, contemporaneamente, através dos meios de comunicação e que é frequentemente televisionada e porque não dizer, espetacularizada?

Enfim, já que se propôs a abordagem do solidarismo jurídico como um marco do direito contemporâneo, convém relembrar alguns outros marcos anteriores.

No paradigma do liberalismo, a Constituição se restringia à esfera pública não sendo "bem-vinda" no campo das relações privadas. Estas relações eram de exclusividade da normativa infra- constitucional, a exemplo do Código Civil. Já no estado social, a autonomia privada passou a sofrer restrições em benefício de interesses coletivos. A ordem civil passou a dividir espaço com a Constituição que trouxe consigo a ratificação de valores solidarísticos ${ }^{7}$.

Quando se fala em "principiologia” se fazem necessárias algumas considerações a respeito das dificuldades procedimentais que surgem ao se trabalhar com categorias tão ampla em significa- do. O Brasil vive um momento de midiatização do Poder Judiciário no qual as decisões tomadas pela Corte Suprema (Supremo Tribunal Federal) são amplamente divulgadas e discutidas ${ }^{8}$. Um dos motivos talvez

\footnotetext{
${ }^{6}$ Cfr. Mônia Clarissa Hennig Leal, Jurisdição Constitucional, 53.

${ }^{7}$ Cfr. Daniel Sarmento, Direitos Fundamentais.

${ }^{8}$ Serve de exemplo as recentes discussões amplamente divulgadas na mídia em torno da (in) constitucionalidade das "vaquejadas". Conforme notícia do Senado Federal: "De um lado, o bem-estar de animais submetidos a estresse, tração nas caudas e quedas arriscadas enquanto tentam escapar dos vaqueiros. De outro, uma prática secular que é tradição cultural no Nordeste, gera empregos e movimenta a economia na região. A polêmica envolvendo as vaquejadas se intensificou em outubro, depois que o Supremo Tribunal Federal (STF) julgou procedente ação do Ministério Público contra a lei que regulamenta as vaquejadas no Ceará. O relator, ministro Marco Aurélio Mello, considerou baver 'crueldade intrínseca' contra os animais." "Legalização das vaquejadas divide opiniões", Isabela Vilar, acesso em novembro 1, 2016, http:// www12.senado.leg.br/noticias/materias/2016/11/01/legalizacao-das-vaquejadas-divide-opinioes.
} 
seja justamente a dificuldade em decidir os casos que chegam às mãos dos juízes constitucionais.

Isto porque os princípios, diferentes das regras, não descrevem condutas determinadas. Os princípios consagram valores e indicam fins públicos a serem perseguidos. Assim, "a definição do conteúdo de cláusulas como dignidade da pessoa humana, razoabilidade, solidariedade e eficiência também transfere para o intérprete uma dose importante de discricionariedade?"”

Dizer o Direito, portanto, é tarefa que hoje ganha espaço de protagonismo na mídia.

A colisão entre normas constitucionais é fenômeno natural no constitucionalismo contemporâneo. Exemplo disso é a possibilidade de choque entre a proteção ambiental de um lado e a promoção do desenvolvimento de outro, embora fosse possível mencionar uma variedade de outros exemplos. No caso da ocorrência de tais choques entre normas hierarquicamente idênticas não se pode encontrar solução em abstrato, sendo necessário ao intérprete criar, no caso concreto, o Direito. Será, portanto, mediante concessões recíprocas (ponderação) que busquem preservar ao máximo cada um dos interesses colidentes que se realizará a verificação de qual deles prevalecerá no caso concreto em razão da sua mais fiel adequação ao espírito constitucional ${ }^{10}$.

Enfim, é possível sintetizar as linhas que conformam o constitucionalismo contemporâneo no Brasil mencionando, em primeiro lugar, a busca pela efetividade prática das disposições constitucionais. Em segundo lugar, os princípios constitucionais, espelho dos valores mais caros à sociedade brasileira exercem o papel de unificadores lógicos do ordenamento jurídico, espalhando a sua sistemática por todas as disposições infraconstitucionais.

Por fim, a textura aberta das disposições constitucionais exige dos aplicadores do Direito um papel criativo mais destacado. Este papel, desempenhado, por

\footnotetext{
${ }^{9}$ Luís Roberto Barroso, "Neoconstitucionalismo e Constitucionalização do Direito: O triunfo tardio do direito constitucional no Brasil”, Revista Questio Iuris 2,1 (2006): 1-48.

${ }^{10}$ Cfr. Luís Roberto Barroso, "Neoconstitucionalismo e Constitucionalização", 1-48.
} 
exemplo, pelos Ministros do Supremo Tribunal Federal, é acompanhado por vezes pela mídia que expõe os casos difíceis que chegam à Suprema Corte e que ganham a atenção da coletividade. Talvez, seja a "vontade de constituição" que desperta a curiosidade popular para os rumos que são traçados cotidianamente para o país pelos operadores do Direito. Esta "vontade" poderia se traduzir em uma "vontade de solidariedade"?

\section{A solidariedade jurídica como princípio fundamental}

Desde as primeiras linhas deste texto se está a falar sobre "princípios". Notadamente, princípios constitucionais. Já não é segredo que se defende aqui a ideia de que a solidariedade está disposta na Constituição Federal brasileira na qualidade de princípio. Mas o que isso significa, afinal?

Contemporaneamente os princípios obtiveram o reconhecimento de que constituem verdadeiras normas jurídicas, dotadas de obrigatoriedade, de forma que a sua observância deve ser garantida pelo Estado. Os princípios informam materialmente a totalidade das normas jurídicas, ou seja, são verdadeiras inspirações para o ordenamento jurídico. Apresentam uma forma mais ampla, mais abstrata que os permite expressar com riqueza os valores fundamentais a serem aplicados a uma extensa gama de relações ${ }^{11}$.

A solidariedade que aqui se trabalha está positivada no artigo $3 .^{\circ}$, inciso I da Constituição Federal, sob o título que consagra os "princípios fundamentais", razão pela qual a abordagem da solidariedade ocupando a qualidade de um princípio vem sendo realizada desde o início do texto ${ }^{12}$.

A solidariedade é um ramo que se estende após a incorporação da igualdade, pois a construção de uma "sociedade solidária", pressupõe a prévia incorporação da igualdade

\footnotetext{
${ }^{11}$ Walter Claudius Rothenburg, "Verbete: "Princípios"”, in Dicionário Brasileiro de Direito Constitucional, coord. Dimitri Dimoulis (2. ${ }^{a}$ ed., São Paulo: Saraiva, 2012).

${ }^{12}$ Conforme menciona Maria Celina Bodin de Moraes: "antes de serprincípio jurídico, a solidariedade é também virtude ético-teologal." Maria Celina Bodin de Moraes, "O Princípio da Solidariedade", in A construção dos novos direitos, org. Ana Carla Harmatiuk Matos (Porto Alegre: Núria Fabris, 2008, 239).
} 
pelo contexto constitucional. Oriunda de uma matriz religiosa, contemporaneamente a solidariedade se estende pelo campo das complexas relações sociais ${ }^{13}$.

León Duguit" ${ }^{14}$ em sua obra "Fundamentos do Direito" explica que o homem vive naturalmente em sociedade, de forma que a consciência da sua individualidade convive com a consciência da sua sociabilidade. De acordo com Duguit, é a solidariedade social que cria o laço que mantém os homens unidos. Porém, estes laços são ainda muito frágeis, posto que a humanidade se subdivide em uma infinidade de grupos sociais, e comumente o homem só se solidariza verdadeiramente com aqueles que fazem parte do seu grupo social.

Conforme o contexto social, a solidariedade se manifesta como força de coesão por similitude ou por divisão do trabalho social, sendo que a sociedade se revela mais forte quanto mais nítidos forem os laços de solidariedade entre seus integrantes ${ }^{15}$.

Não é sem motivo que a Constituição Federal de 1988 dispôs como um objetivo fundamental, ao lado da construção de uma sociedade livre e justa a construção também de uma sociedade solidária.

Os direitos relacionados à fraternidade ou solidariedade ${ }^{16}$ surgiram da constatação da necessidade de colaboração entre países com a finalidade de superação das diferenças entre nações desenvolvidas e subdesenvolvidas. São chamados de direitos fundamentais de terceira dimensão e se relacionam com questões como o meio ambiente e o desenvolvimento entre outras ${ }^{17}$.

Em termos jurídicos a solidariedade abarca uma gama de instrumentos que se voltam para garantir a todos uma existência digna livre de excluídos e de marginalizados ${ }^{18}$. Note-se, inclusive, que não se trata de um sentimento beneficente, pois este se circunscreve no âmbito da consciência, enquanto que

\footnotetext{
13 Martonio Mont'Alverne Barreto Lima, "Verbete: "Solidariedade"” in Dicionário Brasileiro de Direito Constitucional, coord. Dimitri Dimoulis (2. ${ }^{a}$ ed., São Paulo: Saraiva, 2012).

${ }^{14}$ Léon Duguit, Fundamentos do Direito (Trad. Márcio Pugliesi, São Paulo: Martin Claret, 2009).

${ }^{15}$ Cfr. Léon Duguit. Fundamentos do Direito.

${ }^{16}$ Guardadas as devidas diferenças entre os termos "fraternidade" e "solidariedade".

${ }^{17}$ Marcelo Novelino, Manual de Direito Constitucional (8. ${ }^{\circ}$ ed. rev. e atual., São Paulo: Método, 2013).

${ }^{18}$ Cfr. Maria Celina Bodin de Moraes, "O Princípio da Solidariedade".
} 
a solidariedade aqui abordada e insculpida no texto constitucional é um dever jurídico ${ }^{19}$.

Fica aqui o protesto, inclusive, a respeito do pouco espaço dedicado pela literatura jurídica à perspetiva dos deveres fundamentais. Mas e em termos práticos, como este princípio se efetiva no mundo dos fatos? Este é o objeto de análise do próximo tópico.

\section{O solidarismo jurídico no constitucionalismo contemporâneo brasileiro: aplicações práticas}

Não haveria sentido em se construir todo um arcabouço teórico em torno do princípio da solidariedade sem que houvesse uma forma de aplicação prática de toda esta construção.

No que tange à seara contratual, a solidariedade remodela a função social do contrato, que deixa de revelar um caráter estritamente patrimonial e passa a abarcar também um viés social. $\mathrm{O}$ contrato não é mais visto como um instrumento de "egoísmo" e passa a ser observado como instrumento de justiça social. Os contratantes passam a ter o dever de se conduzir de maneira cooperativa, de forma que o núcleo da obrigação deixa de ser a vontade e passa a ser o respeito à dignidade das partes ${ }^{20}$.

Não se quer dizer que a vontade das partes tenha sido suprimida, mas sim que há um equilíbrio entre vontades e dignidade sob esta perspetiva constitucionalizada.

No âmbito da responsabilidade civil, Maria Celina Bodin de Moraes ${ }^{21}$ menciona que o fundamento da responsabilidade objetiva é encontrado na conceção solidarista inaugurada pela Constituição Federal de 1988 que protege qualquer pessoa que tenha sido, de maneira injusta, lesada. De acordo com a autora, "em decorrência do princípio

\footnotetext{
${ }^{19}$ Cfr. Maria Celina Bodin de Moraes, "O Princípio da Solidariedade".

${ }^{20}$ Eros Belin de Moura Cordeiro, "Repersonalização, Solidarismo e Preservação do Contrato: em busca do papel contemporâneo da revisão contratual", Constituição, Economia e Desenvolvimento: Revista da Academia Brasileira de Direito Constitucional 2 (2010).

${ }^{21}$ Maria Celina Bodin de Moraes, "A constitucionalização do direito civil e seus efeitos sobre a responsabilidade civil", Direito, Estado e Sociedade 9,29 (jul/dez 2006).
} 
constitucional de solidariedade social, pois, distribuem-se as perdas e estende-se o mais amplamente possivvel as garantias à integridade psicofísica e material de cada pessoa humana".

Outro exemplo de aplicação do princípio da solidariedade foi a desapropriação de um imóvel rural localizado no Pantanal Mato-Grossense. Esta decisão teve como base a imposição decorrente da função social de utilização adequada de recursos e de preservação do meio ambiente do local. Neste caso, o Supremo Tribunal Federal entendeu que o respeito ao meio ambiente constitui um direito de terceira geração que espelha o princípio da solidariedade ${ }^{22}$.

Os direitos relacionados ao ideário solidarista, chamados de direitos de "terceira geração" direcionam-se, por vezes, ao próprio gênero humano e não a um ou outro indivíduo. Entre estes direitos se pode mencionar o direito à paz internacional, ao desenvolvimento, à comunicação, ao meio ambiente entre outros ${ }^{23}$.

Percetível, portanto, que a conceção solidarista é uma conceção que ultrapassa os limites dos direitos individuais e amplia os horizontes do Direito para uma perspetiva coletiva. Até mesmo os direitos das futuras gerações estão abarcados por esta lógica.

Enfim, estes breves apontamentos buscam traças uma rápida ideia acerca do Direito Constitucional contemporâneo e da solidariedade como um marco qualitativo deste constitucionalismo.

\section{Considerações finais}

$\mathrm{Na}$ sequência do exposto, impõem-se algumas considerações a título de conclusão. A primeira delas é a de que é papel do operador do Direito estar atento às transformações sociais que inevitavelmente conformarão a leitura do ordenamento jurídico. Perceba-se que um olhar menos apurado pode levar o intérprete do Direito a tomar conclusões equivocadas.

O princípio da solidariedade, insculpido como princípio fundamental da República Federativa do Brasil traz ao ordenamento jurídico uma perspetiva

\footnotetext{
${ }^{22}$ Cfr. Maria Celina Bodin de Moraes, "O Princípio da Solidariedade".

${ }^{23}$ Cfr. Maria Celina Bodin de Moraes, "O Princípio da Solidariedade".
} 
transindividual que se espalha por todos os institutos jurídicos. Assim, seja em questões ambientais, seja no âmbito familiar, seja nos contratos ou em qualquer outro ramo do Direito, há que se ter em mente esta perspetiva que coloca o bem comum acima dos interesses puramente individuais.

Por fim, é preciso lembrar que a textura aberta das normas constitucionais conclama os intérpretes do Direito a atribuir o seu sentido e o seu alcance. Desta forma há também um ônus a estes operadores jurídicos de esclarecer as razões pelas quais compreendem as disposições constitucionais da forma como compreendem, ou seja, decisões genéricas e fundamentações rasas não são apenas desaconselháveis como também se mostram incompatíveis com o sistema constitucional vigente e, portanto, são eivadas de inconstitucionalidade. 


\title{
A transparência dos atos da administração pública como mecanismo de combate à corrupção através do controle social: uma análise do caso brasileiro e português
}

\author{
Juliana Machado Fraga* / Luiz Felipe Nunes*
}

RESUMO: O presente trabalho tem o escopo de abordar uma das maiores garantias do Estado Democrático de Direito, o pleno acesso às informações públicas. Assim, a transparência dos atos da administração pública evidencia-se como uma possibilidade de um mecanismo de combate à corrupşão através da abertura de espaços democráticos para incidência de participação e consequentemente do exercício do controle social. Nesse sentido, tem-se que a nova matriz constitucional do Estado Democrático de Direito facilita a transparência e publicidade dos atos de gestão pública, assim, é importante a análise do papel da sociedade civil e dos "media" perante essa possibilidade de controle dos atos da administração pública. Objetivou-se, então, uma análise quanto à realidade brasileira e portuguesa acerca da transparência na divulgação das informacões públicas como forma de capacitar seus cidadãos ao exercício do controle social da corrupção, bem como sen papel perante a possibilidade de controle social. Empregou-se o método dedutivo para direcionar a pesquisa documental e bibliográfica sobre o direito ao acesso à informação pública enquanto instrumento no combate à corrupção.

PALAVRAS-CHAVE: Administração pública - controle social - corrupção - democracia - transparência.

ABSTRACT: This study has the scope to address one of the biggest guarantees of the democratic rule of law, full access to public information. Thus the transparency of the acts of public administration is evidenced as a possibility of a mechanism to combat corruption through the opening of democratic spaces for incidence of participation and consequently the exercise of social control. In this sense, there is the new constitutional matrix of Law Democratic State facilitates transparency and publicity of the acts of public management, so it is important to analyze the role of civil society and the "media" before the possibility of control of the acts public administration. The objective, then, an analysis on the Brazilian and Portuguese reality and transparency in the dissemination of public information in order to enable its citizens to exercise social control of corruption, as well as its role in the possibility of social control. the deductive method was employed to direct the documentary and bibliographical research on the right to access to public information as a tool in fighting corruption.

KEYWORDS: public administration - social control - corruption - democracy - transparency.

\footnotetext{
${ }^{1 *}$ Doutoranda em Direito na Universidade de Santa Cruz do Sul - UNISC. Mestre em Direitos Sociais e Políticas Públicas pela UNISC e em Direitos Humanos pela Universidade do Minho.

$2^{2 * *}$ Doutorando e Bolsista CAPES/Prosup na Universidade de Santa Cruz do Sul - UNISC.
} 


\section{Introdução}

A efetiva transparência dos atos da administração pública demonstra-se como uma ampliação dos métodos de combate à corrupção por meio da participação cidadã e pela possibilidade do exercício do controle social. Com a nova matriz constitucional do Estado Democrático de Direito há uma facilitação dos mecanismos e políticas públicas voltadas à transparência e publicidade dos atos da administração pública, tornando a cultura do segredo, que vigorava até então, meramente uma exceção à nova perspetiva de publicização dos atos públicos.

Nesse tocante, é de extrema relevância que se aprecie o papel da sociedade civil e dos "media”, ou seja, a mídia possuem papel fundamental no controle dos atos da administração pública. O objetivo deste escorço é a análise das realidades brasileira e portuguesa quanto à transparência na divulgação das informações públicas como mecanismo de capacitação dos cidadãos para o controle social dos atos da gestão pública e consequentemente do combate à corrupção. Para tal feito empregou-se o método dedutivo direcionando a pesquisa documental e bibliográfica acerca do direito ao acesso à informação pública como forma de combate à corrupção através do controle social.

\section{O Estado Democrático de Direito e sua nova matriz constitucional: a transparência dos atos da administração pública}

A partir do advento da nova ordem constitucional o Brasil aderiu a uma nova fase constitucional, na qual a sociedade passa a ser cogestora do interesse público. A Constituição Federal de 1988 trouxe consigo a publicidade dos atos da administração e a inserção popular nos assuntos de gestão pública, ocasionando uma crescente inclusão social e majorando a cidadania ativa. Coube ao Estado garantir o mínimo ideal para informação do cidadão e criar políticas públicas capazes de possibilitar o exercício da cidadania ativa ${ }^{1}$.

\footnotetext{
${ }^{1}$ Noam Chomsky, Sobre el poder y la ideología: conferencia de Managua 2 (1. ${ }^{\text {a }}$ ed. Madrid: VISOR Lingüística y Conocimiento, 1989), 141.
} 
Desde que instaurada a nova matriz constitucional brasileira, teve-se uma alteração no pensamento social, pois a censura ideológica até então instaurada pelo regime militar deu lugar às liberdades de acesso à informação da administração pública no país. Portanto, o direito de informação pode ser entendido como uma forma de amadurecimento democrático de um país, pois o conhecimento de fatos e das situações de interesse geral tem o condão de informar e interliga-se com o direito de ser informado. A liberdade de informação compreende a liberdade de informar e a liberdade de ser informado ${ }^{2}$.

Hodiernamente o direito de informação possui natureza individual e social, ao passo que se caracteriza como direito individual quando consiste no poder de se expressar e de manifestar opiniões, e, também, por sua vez, quando envolve a comunidade, e quando se projeta para os atos da administração pública, exigindolhes transparência, publicidade, moralidade etc, objetivando um maior controle dos atos do Estado ${ }^{3}$, ele manifesta sua natureza social, difusa, coletiva ${ }^{4}$.

Com a promulgação da Lei de Acesso à Informação Pública, em 18 de novembro de 2011, realmente inicia-se uma nova fase relativa ao acesso à informação no Brasil. Sob o fundamento basilar do princípio da legalidade, impessoalidade, moralidade, publicidade e eficiência, conforme preceitua o art. 37, caput, da Constituição Federal de 1988, e tendo como essência o princípio constitucional da publicidade e transparência dos atos da administração pública, configurando, então, o segredo como mera exceção, aceito sob justificativa inexorável, compete ao Estado o fornecimento da informação requerida de forma clara, rápida e objetiva, consoante dispõe o artigo 5. da Lei 12.527/2011. Essa nova lei, em conjunto com a Constituição Federal e demais

\footnotetext{
${ }^{2}$ José Afonso da Silva,. Curso de direito constitucional positive (São Paulo: Malheiros Editores, 2002).

${ }^{3}$ Rogério Gesta Leal, Verdade, memória e justiça no Brasil: responsabilidades compartidas: morte, tortura, sequestro e desaparecimento de pessoas no regime militar brasileiro: de quem é a responsabilidade? (Porto Alegre: Livraria do Advogado Editora, 2012).

4 "Assuntos de interesse público são aqueles assuntos que dizem respeito às escolhas que a pessoa deve fazer, como membro de sua comunidade, que interessem às demais e nelas interfiram, bem como que influenciem e interfiram no que pertine à sua organização política e social", e "Os assuntos de interesse privado de expressão coletiva são aqueles considerados importantes para o desenvolvimento da sociedade" vd. Rosita E. Carvalho, "Integração e inclusão: do que estamos falando?", in Salto para o futuro: tendências atuais, (Brasília: Ministério da Educação - Secretaria de Educação a Distância, 1999).
} 
preceitos sobre a matéria abriram maiores espaços democráticos de participação cidadã na medida em que trazem a transparência dos atos administrativos ${ }^{5}$.

\section{O combate à corrupção a partir de mecanismos de controle social}

A participação social é um dos princípios basilares dos Estados Democráticos de Direito, modelo este adotado pela Constituição Federal de 1988. O principal fundamento é a ampliação do papel dos atores sociais, a fim de garantir instrumentos para que os cidadãos possam controlar os atos dos gestores públicos.

Observando a história do Estado moderno, pôde-se demonstrar que o nível de corrupção, que sempre esteve presente na sociedade, tem aumentado gradualmente com a globalização, ao passo que expande mais facilmente as fronteiras da criminalidade, e, infelizmente, da impunidade também ${ }^{6}$. É possível assegurar que as práticas corruptivas se alastram e se impregnam na sociedade, tornando-se um problema crônico mundial. É preciso encontrar formas de comunicação dos diversos meios de repressão a essas práticas $^{7}$. Nesse sentido, ressalta-se que o combate à corrupção só é possível quando há uma união entre políticas públicas eficientes e sociedade civil ativa. Assim, o problema da falta de eficácia nos controles públicos brasileiros pode ser associado ao controle direto da sociedade civil acerca da corrupção. ${ }^{8}$

Dessa maneira, percebe-se que a participação é inerente à transparência e com estes aliados é possível haver o controle social, pois não é possível exercer o controle do que não se tem conhecimento, motivo pelo qual é imperioso que se tenha transparência dos atos públicos ${ }^{9}$. O exercício do controle social é justamente

\footnotetext{
${ }^{5}$ Maria Eduarda Gonçalves, Direito da informação: novos direitos e formas de regulação na sociedade de informação. (Coimbra: Livraria Almedina, 2003).

${ }^{6}$ Rogério Gesta Leal, Patologias corruptivas nas relações entre Estado, Administração Pública e Sociedade - Causas consequências e tratamentos (Santa Cruz do Sul: Edunisc, 2013).

${ }^{7}$ Evelina Dagnino, "Concepciones de la ciudadanía en Brasil: proyectos políticos en disputa" in sociedade civily participación politica, comp. Isidoro Cheresky (Madrid: Miño y Dávila, 2006).

${ }^{8}$ Fernando Gil Villa, La cultura de la corrupción (Madrid: Maia ediciones, 2008).

9 "Programa Olho Vivo no Dinheiro Público", Ministério da transparência, fiscalização e ControladoriaGeral da União, acesso em novembro 16, 2016, http:/ /www.cgu.gov.br/assuntos/controle-social/olhovivo.
} 
a possibilidade da sociedade verificar se uma determinada atividade pública se desvia dos objetivos ou dos princípios previstos pela norma constituinte. ${ }^{10}$ Cabe à sociedade civil o monitoramento das instituições e dos processos aplicados pela gestão pública, sendo essencial para um diagnóstico regular os mecanismos de combate à corrupção.

\section{O papel da sociedade civil e os "media": em análise o caso brasileiro e português}

A crise da democracia em grande parte caracteriza-se como uma crise do modelo representativo, no qual os governantes quando eleitos esquecem-se de seus tutelados e passam a representar interesses próprios ou de parcelas minoritárias da população cujo poder aquisitivo é maior em troca de favorecimentos. Sob a falta de interesse na política e o declínio da militância é percetível a falta de confiança na máquina estatal face aos atos de seus representantes. Nesse sentido, a democracia é um conjunto de regras que definem quem está autorizado a tomar as decisões de gestão, mas acima disso, define os valores fundamentais que permeiam o governo e estes se traduzem nos princípios da igualdade, liberdade, transparência, legalidade, entre outros. Logo, a democracia consubstancia-se na premissa da capacidade eleitoral ativa e passiva. Isso significa dizer que todos podem votar e participar da gestão como todos podem se opor ao governo.

Para que estes pressupostos do Estado Democrático de Direito sejam efetivamente cumpridos é essencial que a administração pública se valha de mecanismos de transparência a fim de garantir que o sistema político torne-se claro para seus tutelados e com isso possa garantir a legalidade e legitimidade na tomara de decisões sob o viés do controle social cidadão. Logo, tem-se que o papel da sociedade civil e dos media são essenciais ao combate à corrupção.

$\mathrm{O}$ aparelho de justiça por vezes recorre aos media para aliar estratégias que visam ancorar o exercício de suas funções ao da sociedade civil, promovendo informação

\footnotetext{
${ }^{10}$ Luís de Sousa e João Triães, Corrup̣cão e os portugueses (Cascais: RCP, 2008).
} 
clara e verídica à comunidade. Os media ajudam ou prejudicam a transferência da informação para o tutelado perante seus governantes ${ }^{11}$. Os media detetam, publicizam e dramatizam a informação. Esta anemia cívica hoje constatada deve-se à minimização de deveres e maximização dos direitos. É necessária uma alteração do pensamento social com um "revigoramento cívico" trazendo um discurso claro acerca dos direitos e dos deveres do cidadão, facilitando a formulação de um pacto de integração entre todos componentes deste meio ${ }^{12}$.

\section{Considerações finais}

Entende-se que para recuperar a credibilidade nas instituições de governo, é preciso demonstrar transparência e seriedade em suas ações, para isso os media ou a mídia pode auxiliar à sociedade civil possibilitando maior interação dos cidadãos com o conhecimento dos atos corruptivos. É preciso ainda que o cidadão seja inserido nas metas governamentais, e deixando-o a par dos assuntos públicos através de políticas públicas de transparência e controle social. De outra banda, para refrear a corrupção, combatendo-a efetivamente, é necessário que o cidadão assuma uma postura proativa, assim se buscará uma democracia que atenda à coletividade com a cidadania figurando-se como crucial para a eficácia do controle governamental.

As experiências sociais, tanto a brasileira quanto a portuguesa, evidenciam que a perceção da corrupção tem se dado de forma gradual, com auxilio dos media, que possibilitam inserção dos cidadãos nos assuntos de gestão. Nessa feita, entende-se que o papel da cidadania ativa é essencial para o deslinde desta série de atos corruptivos que vemos frequentemente noticiados e para o posterior controle social. Contudo, ainda há muito que se trabalhar para a maior incidência de políticas públicas de transparência e para fomentar o papel dos media como veiculadores de informação.

\footnotetext{
${ }^{11}$ Luís de Sousa e João Triães, Corrup̣ção.

${ }^{12}$ Andreia Sofia Pinto Oliveira, "Responsabilidade e Cidadania", in: Anuário publicista da Escola de Direito da Universidade do Minho (Tomo I, Braga: Escola de Direito da Universidade do Minho, 2012).
} 


\section{Prolegômenos interconstitucionais: para uma teoria da constitucionalidade europeia}

\section{Larissa A. Coelho*}

RESUMO: As transformações decorrentes do processo de integração europeia não produzem efeitos apenas nos campos econômicos e sociais, por isso a doutrina juridica tem questionado qual o impacto dessas mudanças sobretudo diante de um cenário de crise sobre o pensamento jurídico, em especial no campo do direito constitucional, em que suscitam questões acerca da teoria da constitucionalidade. Uma possível solução tem sido apontada pelos doutrinadores que a designam por teoria da interconstitucionalidade. Analisando a teoria da constitucionalidade e da interconstitucionalidade, somos levados a concluir que a segunda já possui uma resposta para o debatido problema do poder constituinte em sede da Constituição Europeia, mas ainda não possui uma resposta aos novos problemas com que o direito europeu passou a lidar nos tribunais.

PALAVRAS-CHAVE: teoria da constitucionalidade - teoria da interconstitucionalidade - constituição europeia integração política - União Europeia.

ABSTR ACT: The transformations due to the european integration process don't produce effects only in economical and social fields, hence the legal doctrine has been questioning what is the impact of those changes mainly in front of a crisis scenario about legal thinking, specially in the constitutional law field, where questioning about constitutional theory are raised. A possible solution has been pointed out by doctrinators which name it interconstitutionality theory. Analysing constitutionality and interconstitutionality theory, we're of concluding that the second already has an answer to the debated constituent power problem in the European Constitution, but still doesn't have an answer to the new problems that the european law has been dealing with in courts.

KEYWORDS: constitutionality theory - interconstitutionality theory - European constitution - political integration - European Union.

* Doutoranda em Ciências Jurídicas Públicas na Universidade do Minho. Membro não Doutorado do Centro de Estudos em Direito da União Europeia - CEDU. 
O processo de integração europeu desde a sua origem com a criação da Comunidade Europeia do Carvão e do Aço (1951) e da Comunidade Econômica Europeia - CEE (1957) tem passado por períodos intercalados entre integração, alargamento e crises. Desde 2008 encontra-se diante do seu maior teste de resistência pois que em razão das medidas de austeridade e a redução do Estado social passou a ser questionada não apenas por decisores políticos, mas sobretudo pelos próprios cidadãos que influenciados por infortúnios pessoais e/ou ideologias antieuropeístas pedem a saída dos seus países, como ocorreu com o Brexit, dando sequência ao que se designa por "[...] a crise de legitimidade da União". Por outro lado, defendem os europeístas que vivenciamos o momento em que se faz necessário mais aprofundamento na integração, não apenas econômica como tem sido feito nos pacotes de economic governance mas sobretudo política, uma vez que é a própria integração econômica que nos direciona para uma união política².

Deste modo, a doutrina tem questionado qual o impacto da crise e das mudanças de pensamento que ela tem gerado no plano jurídico, em especial no campo do direito constitucional, em que se suscitam questões como qual seria a teoria da constitucionalidade que necessita a União Europeia hoje para que possa contribuir com um maior aprofundamento na integração, sendo apresentado por doutrinadores na linha de Gomes Canotilho e Alessandra Silveira influenciados pela filosofia habermasiana a teoria da interconstitucionalidade.

Entretanto, para que possamos compreender a teoria da interconstitucionalidade, é preciso primeiramente entender a teoria clássica da constitucionalidade, embora argumente Gomes Canotilho que em função dos problemas que enfrenta o

\footnotetext{
${ }^{1}$ Cfr. Eugénia da Conceição, O futuro da União Europeia (Lisboa: Fundação Francisco Manuel dos Santos, 2016), 29 - 32, descreve que "o fim do consenso permissivo e o início do período de dissenso constrangedor no período pós-Maastricht são comprovados pela contestação e pela politização geral e por uma ruptura entre as elites políticas e os cidadãos em relação ao aprofundamento da integração e à transferência automática de competências para a UE".

${ }^{2}$ Cfr. Alessandra Silveira, "Teoria da interconstitucionalidade: entre os processos de constitucionalização e democratização da UE”, in Interrelación filosófico-jurídico multinivel. Retos de un mundo global, coord. Gonçal Mayos e Jose Carlos Remotti (Barcelona: Ed. Linkgua, s/d), 1 - 2 (no prelo).
} 
constitucionalismo não possamos afirmar que exista uma teoria clássica ${ }^{3}$. Neste artigo, utilizaremos o termo clássico em contraposição aos fenômenos inter ${ }^{4}$, dentre os quais se insere a interconstitucionalidade.

O termo constitucionalismo associado à ideia de um documento escrito, supremo, que congrega a organização do Estado e da comunidade, surge em finais do século XVIII com os processos historicamente conhecidos por Revoluções Liberais, que compreendem a título de exemplo na Europa a Revolução Francesa (1789) e na América a Independência Americana (1776).

De acordo com Luís Roberto Barroso, constitucionalismo significa a "[...] limitação do poder e supremacia da lei (Estado de direito, rule of law, Rechtsstaat)" em que apesar do nome sugerir a existência do documento escrito - uma Constituição, essa "[...] associação nem sempre é necessária ou verdadeira". No entanto, para que tal documento tenha valor no ordenamento jurídico, explica o citado autor é preciso que a Constituição seja "[...] dotada de determinados atributos e que tenha legitimidade, adesão voluntária e espontânea de seus destinatários" $"$.

Deste modo, o termo Constituição não é entendido apenas como os limites e pilares da organização do Estado como foi caracterizado no período oitocentista,

\footnotetext{
${ }^{3}$ Cfr. J. J. Gomes Canotilho, Direito constitucional e teoria da constituição (7a ed., $15^{\mathrm{a}}$ reimp., Coimbra: Almedina, 2003), 1333.

4 Por fenômenos "inter" entendemos as teorias da interconstitucionalidade, interculturalidade, interjusfundamentalidade, internormatividade e interjurisdicionalidade, que assentam no critério de partilha e troca, de um diálogo entre culturas jurídicas. Para, Alessandra Silveira, "Interconstitucionalidade: normas constitucionais em rede e integração europeia na sociedade mundial", in Interconstitucionalidade e interdisciplinariedade: desafios, âmbitos e niveis de interação no mundo global, coords. Alexandre Walmott e Saulo Pinto Coelho (Uberlândia: Edição Laboratório Americano de Estudos Constitucionais Comparado LAECC, 2015), 27, correspondem a nova metódica que busca fundamentar em termos jurídico-políticos o processo de integração europeia correspondente à construção do constitucionalismo europeu. De acordo com Gonçal Mayos, "Interconstitucionalidad e interculturalidad como modelos de 'fenómenos inter", in Interconstitucionalidade e interdisciplinariedade, 6 e ss., os fenômenos inter são impulsionados por processos provenientes da sociedade pós-industrial que têm levado a novos conflitos no campo do direito constitucional, podendo os mesmos serem explicados em função da economia, geopolítica, demografia e razões socioculturais.

${ }^{5}$ Cfr. Luís Roberto Barroso, Curso de direito constitucional contemporâneo: os conceitos fundamentais e a construção do novo modelo ( $5^{a}$ ed., São Paulo: Saraiva, 2015), 29 (itálicos no original).

${ }^{6}$ Cfr. Barroso, Curso de direito constitucional, 29.
} 
mas sim, como um mecanismo que "[...] desempenha relevante papel como instrumento de estabilidade, de racionalização do poder e de garantia da liberdade"7. Em virtude desta perspetiva é um documento que ao ser conjugado com conceções como Estado de Direito, Democracia e Cidadania, compreende não só a proteção de um povo como fornece padrões mínimos para uma vida condigna.

Sendo desenvolvidas ao longo da história várias teorias que procuravam identificar a natureza, o papel e o significado da Constituição como por exemplo a conceção sociológica de Ferdinand Lassalle, a positivista de Kelsen, a histórica de Burke, a decisionista de Schmitt, a marxista, dentre outras, atualmente, segundo a doutrina, estamos diante da ideia de Constituição normativa que se encontra condicionada ao tempo e espaço no qual vigora, que carrega os traços sociais e políticos, mas que vive à luz de uma permanente tensão entre a realidade e a norma resultando nos limites ao direito constitucional ${ }^{8}$.

Por isso, a teoria da constitucionalidade relaciona-se com a teoria normativa da política", que de acordo com Jorge Miranda compreende o "[...] esforço de elaboração $e$ aprofundamento do seu conceito e de equacionação das questões fundamentais da dogmática constitucional' ${ }^{\prime 0}$. Quanto ao seu conteúdo, a título de exemplo, relaciona-se a temas como a distinção entre princípios e regras; a caracterização das normas constitucionais em programáticas ou diretivas; o regime da aplicabilidade direta e da prevalência das normas constitucionais; a jurisdição constitucional; a jurisprudência constitucional, a interação entre o constitucionalismo e o direito internacional, a relação da teoria da constitucionalidade com a teoria da justiça e dos valores ${ }^{11}$.

Entretanto os fatores desenvolvidos com a globalização, que passam a ser designados como os problemas do século XXI em que temos os avanços tecnológicos,

\footnotetext{
${ }^{7}$ Cfr. Gilmar Ferreira Mendes; Inocêncio Mártires Coelho e Paulo Gustavo Gonet Branco, Curso de direito constitucional (4. ${ }^{a}$ ed. rev. e atual., São Paulo: Saraiva, 2009), 1051.

${ }^{8}$ Cfr. Barroso, Curso de direito constitucional, 105.

${ }^{9}$ Cfr. Canotilho, Direito constitucional, 1335; Miguel Poiares Maduro, A Constituição Plural: constitucionalismo e União Europeia (Cascais: Principia, 2006), 336.

${ }^{10}$ Cfr. Jorge Miranda, Manual de Direito Constitucional ( $7^{\mathrm{a}}$ ed., rev. e actual., Coimbra: Coimbra Editora, 2013, Tomo II), 70.

${ }^{11}$ Cfr. Miranda, Manual de Direito Constitucional, 57.
} 
o corporativismo, os fenômenos migratórios, a diversidade cultural, as interações econômicas, os problemas ambientais, os conflitos armados, o retrocesso no Estado social e a necessidade crescente por parte dos Estados de se integrarem regionalmente em espaços transnacionais e supranacionais ${ }^{12}$, leva a afirmações como a proferida por Gomes Canotilho de que hoje está em crise " [...] um conceito de constituição referido exclusivamente ao estado"13, devendo esta ser compreendida materialmente de acordo com a interpretação desenvolvida por Peter Häberle de constituição aberta ${ }^{14}$.

Em razão deste conjunto de elementos ganha força a doutrina sobre um constitucionalismo global, que em termos regionais é um fenômeno que refletese na teoria da interconstitucionalidade ${ }^{15}$. Definida como o diálogo constitucional, ou ainda como a "[...] influência recíproca de certas Constituições ou das jurisprudências constitucionais de uns países sobre as de outros paises" "16, a teoria da interconstitucionalidade segundo Gomes Canotilho estuda as relações interconstitucionais " [...] da concorrência, convergência, justaposição e conflito de várias constituições e de vários poderes constituintes no mesmo espaço político" ${ }^{17}$, sendo este um termo preferível ao termo constitucionalismo multilateral. Para Alessandra Silveira, esta teoria "[...] pressupõe a convivência de normas constitucionais em rede no mesmo espaço político, o da UE [...] [ou seja, decorre do] fenômeno da pluralidade de fontes constitucionais [...]"18, embora estejam diante de um contexto jurídico-constitucional não hierarquizado, a teoria apresenta como um dos problemas centrais a conceitualização de um poder constituinte cujas fontes e seus legitimadores

\footnotetext{
${ }^{12}$ Cfr. Miranda, Manual de Direito Constitucional, 56.

${ }^{13}$ Cfr. Canotilho, Direito constitucional, 1337.

${ }^{14}$ Cfr. Peter Häberle, Die offene Gesellschaft der Verfassungsinterpreten. Ein Beitrag zur pluralistischen und "prozessualen" Verfassungsinterpretation (1975, tradução portuguesa por Gilmar Ferreira Mendes, Hermenêtica constitucional: a sociedade aberta dos intérpretes da constituição: contribuição para a interpretação pluralista e "procedimental" da Constituição. Porto Alegre: Sergio Antonio Fabris Editor, 2002).

${ }^{15}$ Cfr. Miranda, Manual de Direito Constitucional, 68.

${ }^{16}$ Cfr. Miranda, Manual de Direito Constitucional, 69.

${ }^{17}$ Cfr. J. J. Gomes Canotilho, "Brancosos" e interconstitucionalidade: itinerários dos discursos dos discursos sobre a historicidade constitucional (2 $2^{\mathrm{a}}$ ed., Coimbra: Almedina, 2008), 266; Canotilho, Direito constitucional, 1425.

${ }^{18}$ Cfr. Silveira, Teoria da interconstitucionalidade, 4 - 5. Esta teoria pretende conforme defende a citada autora definir a identidade do constitucionalismo europeu, justificando-se no pluralismo constitucional da União Europeia.
} 
são diferentes ${ }^{19}$. Esta ideia foi cunhada por Francisco Lucas Pires na obra Introdução ao Direito Constitucional Europeư ${ }^{20}$.

Neste contexto, a constituição entendida como um texto que reflete a memória e a identidade política de um povo ${ }^{21}$, impregnada por fatores culturais suscita problemas quando pensada num âmbito regional, especificamente no tratamento de uma Constituição para a UE, sobretudo quanto à delimitação do seu poder constituinte. Segundo Gomes Canotilho o problema reside no fato de ainda compreendermos a constituição de acordo com os parâmetros estatais, no qual o poder constituinte corresponde a um momento simbólico e histórico em que se edita um texto com valor de lei superior. Para o citado autor a associação rígida entre constituição e poder constituinte, entendidos em termos clássicos, não se coaduna com os esforços e desafios impostos por um processo de integração regional, tampouco com a ideia de um constitucionalismo globalizado. É, portanto, necessário que ultrapassemos os paradigmas umbilicais entre Constituição e Estado, bem como da dependência da existência de um momento constituinte ${ }^{22}$.

Poiares Maduro argumenta que o momento constituinte europeu não pode ser identificado simbolicamente uma vez que ele decorre de forma paulatina através do desenvolvimento judicial do Tribunal de Justiça da UE e dos tribunais nacionais ao aplicarem o direito europeu, mas também da ampliação do poder político da UE. Entretanto são fatores que têm sido construídos por "[...] referência a fontes constitucionais nacionais" Deste modo o poder constituinte decorre da interpretação dos tratados e da colaboração dos diversos atores jurídicos e políticos. O afastamento da noção clássica de um poder constituinte demarca um caminho autoconstrutivo do constitucionalismo europeu ${ }^{24}$.

\footnotetext{
${ }^{19}$ Cfr. Canotilho, "Brancosos" e interconstitucionalidade, 267 - 268; Silveira, Teoria da interconstitucionalidade, 5; Silveira, Interconstitucionalidade: normas constitucionais em rede, 23.

${ }^{20} \mathrm{Cfr}$. Francisco Lucas Pires, Introdução ao Direito Europeu: seu sentido, problemas e limites (Coimbra: Almedina, 1997), 18 e ss.

${ }^{21}$ Cfr. Canotilho, "Brancosos" e interconstitucionalidade, 269 e ss.

${ }^{22}$ Cfr. Canotilho, "Brancosos" e interconstitucionalidade, 282 - 283.

${ }^{23}$ Cfr. Maduro, A Constituição Plural, 344; Silveira, Interconstitucionalidade: normas constitucionais em rede, 43 $-44$.

${ }^{24}$ Cfr. Pires, Introdução ao Direito Europeu, 75.
} 
Uma vez que a Constituição Europeia tem sido depreendida da interpretação e aplicação dos tratados juntamente com a Carta de Direitos Fundamentais da UE ${ }^{25}$, para nós a discussão do momento constituinte poderia ser ultrapassada entendendo que este ocorreria no momento da ratificação pelos Estados-Membros desses mesmos instrumentos jurídicos, pois como explicitou Lucas Pires as normas comunitárias são fruto de um consenso, ainda que não haja unanimidade ${ }^{26}$. Contudo esta conceção ainda imbricada de um sentido estatal vê-se em causa uma vez que a União atualmente assume poderes que estão além dos limites pré-definidos nos tratados.

O constitucionalismo na Europa, disserta Maduro, surge para efetivar o princípio do primado, ou seja, da "[...] supremacia normativa das suas regras" por empréstimo conceitos constitucionais clássicos como de direitos fundamentais, separação de poderes, Estado de Direito para poder formar o seu corpo jurídico e legitimar a sua autoridade normativa e política ${ }^{28}$, o que a partir da jurisprudência do TJUE assume-se como uma força não apenas jurídica, mas política e autônoma. Em consequência acompanhamos um aumento das competências da União, em matérias não delegadas pelos Estados, a que Maduro designa de europeização, e que se torna legítima pois "[o] tratado é apresentado como muito mais do que um acordo entre Estados - é um acordo entre os povos da Europa"29, ao qual esses mesmos povos têm aderido de forma voluntária e espontânea, preenchendo o conceito apresentado acima por Barroso, a que Habermas designa por transnacionalização da soberania do povo $0^{30}$

\footnotetext{
${ }^{25}$ Neste sentido, Canotilho, Direito constitucional, 1374 constrói a ideia de "constituição evolucionista" que se assenta nos "[...] tratados da Comunidade Europeia, [...] em princípios jurídicos fundamentais, standards, costumes, decisões jurisdicionais, constitutivos de um verdadeiro Jus Commune Europeum e de uma autêntica cultura jurídica europeia" (itálicos no original). Silveira, Interconstitucionalidade: normas constitucionais em rede, 30 - 31.

${ }^{26}$ Cfr. Pires, Introducão ao Direito Europeu, 76.

${ }^{27}$ Cfr. Maduro, A Constituição Plural, 339.

${ }^{28}$ Cfr. Maduro, A Constituição Plural, 345.

${ }^{29}$ Cfr. Maduro, A Constituição Plural, 341.

${ }^{30}$ Cfr. Jürgen Habermas, Essay zur Verfassung Europas (tradução portuguesa por Marian Toldy e Teresa Toldy, Um ensaio sobre a Constituição Europeia. Lisboa: Edições 70, 2012), 74. A mudança no entendimento do poder constituinte decorre da ideia de que a legitimidade não deve estar adstrita a um momento constituinte ou a um quem, no sentido de quem legisla, mas sim na capacidade de resposta e de garantia aos direitos subjetivos que se vêm afetados perante as adversidades, sobre ver Silveira, Teoria da interconstitucionalidade, 8; Silveira, Interconstitucionalidade: normas constitucionais em rede, 32.
} 
Em resposta a essa nova realidade, a Europa se depara com novos problemas, essencialmente relacionados à ideia de um constitucionalismo europeu, pois que passa a colidir constitucionalismo e intergovernamentalismo ${ }^{31}$. Ou seja, por um lado temos um avanço no pensamento constitucional europeu que se torna autônomo à deliberação dos Estados-Membros, mas que lida diariamente com o risco de assumir uma autoridade constitucional colocando em causa as constituições nacionais, e por outro lado temos os Estados-Membros enquanto atores políticos e que seriam os "donos do poder" ainda que partilhado, que deveriam ter uma última palavra em termos políticos, e que passam a não ter mais.

Assim, estamos ante não apenas a uma união de Estados que visam partilhar competências em determinadas matérias, ou mesmo a uma união do tipo federalista. Habermas descreve o atual nível de evolução da União Europeia como um "[...] caminho para a sociedade mundial constituida politicamente", é segundo o autor a "[...] construção de capacidades de ação política além dos Estados nacionais" ${ }^{32}$, resgatando a ideia do cosmopolitismo kantiano ${ }^{33}$, o que corresponde ao aprofundamento da integração política. Chega a afirmar que enquanto mantivermos o discurso direcionado a saber se estamos perante uma federação de Estados ou um Estado federal estaremos tolhendo a evolução da política constitucional ${ }^{34}$.

Face ao exposto, uma vez que a integração europeia representa uma transformação no paradigma do Estado constitucional ${ }^{35}$, em que este já não é identificado como o

\footnotetext{
${ }^{31}$ Cfr. Maduro, A Constituição Plural, 356.

${ }^{32}$ Cfr. Habermas, Essay zur Verfassung, 24 - 62. Esse novo paradigma apontado por Habermas pode ser traduzido na seguinte passagem do autor (77), "[...] temos de admitir como [se tornou] irreversivel a dependência crescente dos Estados nacionais dos constrangimentos sistémicos de uma sociedade mundial cada vez mais interdependente, impõe-se [assim] a necessidade política de alargar os procedimentos democráticos para lá das fronteiras do Estado nacional'.

${ }^{33}$ Para Kant a federação não significava a manutenção do poder de forma concentrada nas mãos de um governo central, antes tinha por intenção um pacto entre povos cuja finalidade era acabar com as guerras em prol da manutenção da paz, cf. Immanuel Kant, Zum ewigen Frieden (1795, tradução portuguesa por Artur Morão, A paz perpétua: um projecto filosófico. Covilhã: LusoSofia, 2008, acesso em abril de 2017, http://www.lusosofia.net/textos/kant_immanuel_paz_perpetua.pdf ), 18.

${ }^{34}$ Cfr. Habermas, Essay zur Verfassung, 82.

${ }^{35}$ Cfr. J. J. Gomes Canotilho; Vital Moreira, Constituição da República Portuguesa Anotada (4ª ed., rev., Coimbra: Coimbra Editora, 2007, Vol I), 243.
} 
referencial para a Constituição, passando a ser a comunidade política ${ }^{36}$, embora ainda em "[...] muitas partes do mundo - talvez, na maior parte - o ideal constitucional e a luta pela liberdade ainda são uma aventura em curso" ${ }^{37}$, no espaço europeu estamos vivenciando os problemas gerados por um constitucionalismo global que reconduz como determina Gomes Canotilho à "[...] regulação de outras dinâmicas sociais [...]"38, assim, os contornos do constitucionalismo a que designamos por clássico dificilmente se tornam adaptáveis às novas estruturas de poder ${ }^{39}$, surgindo deste modo novos atores legitimadores como descreve Habermas, o cidadão europeu, os povos europeus e os Estados-Membros concluindo o citado autor que a crise com a qual atualmente convivemos persiste porque "[o] debate atual restringiu-se às saídas imediatas da atual crise bancária, monetária e da dívida, perdendo de vista a dimensão política"40.

Deste modo, a teoria da interconstitucionalidade conforme as explicações constantes nas obras de Gomes Canotilho, Alessandra Silveira e Poiares Maduro além de buscar atualizar a teoria da constitucionalidade à nova realidade da União Europeia enquanto agente político, eleva a um nível ainda não atingido de integração, o nível político.

Assim, verifica-se que as questões colocadas parauma compreensão dalegitimidade democrática originária do poder constituinte já possui um desenvolvimento teórico, como exprime Lucas Pires, a demarcação histórica imbricada no poder constituinte enquanto agente revolucionário que delimita o nascimento do constitucionalismo não é mais um problema ${ }^{41}$, embora muitos ainda invoquem uma “[...] ligação ontológica do mesmo poder com o Povo" ${ }^{42}$, e neste sentido os atuais processos eleitorais nacionais que decorrem nos Estados-Membros sugerem que paira na Europa a sensação de que cada voto contabilizado nos coloca diante de um reafirmar ou rejeitar o momento

\footnotetext{
${ }^{36}$ Cfr. Silveira, Teoria da interconstitucionalidade, 7.

${ }^{37}$ Cfr. Barroso, Curso de direito constitucional, 30.

${ }^{38}$ Cfr. Canotilho, "Brancosos" e interconstitucionalidade, 286.

${ }^{39}$ Cfr. Canotilho, "Brancosos" e interconstitucionalidade, 291.

${ }^{40}$ Cfr. Habermas, Essay zur Verfassung, 62.

${ }^{41}$ Cfr. Pires, Introdução ao Direito Europeu, 76

${ }^{42}$ Cfr. Paulo Ferreira da Cunha; Joana Aguiar e Silva; António Lemos Soares, História do direito: do direito romano à constituição europeia (Coimbra: Almedina, 2010), 261.
} 
constituinte europeu. Em verdade, o problema do constitucionalismo reside ainda no seu desenvolvimento, como afirmou Lucas Pires, no seu crescimento ${ }^{43}$. Os demais temas que compreendem a teoria da constituição, como por exemplo a jurisdição constitucional ainda se encontram como um território pouco explorado pela doutrina ${ }^{44}$, em que existem muitas perguntas, mas poucas respostas.

\footnotetext{
${ }^{43}$ Cfr. Pires, Introdução ao Direito Europeu, 76.

${ }^{44}$ Cfr. Carlos Ortega Santiago, "La anulación total o parcial de los actos legislativos comunitarios por el Tribunal de Justicia de la Unión Europea”, UNED. Teoría y Relaidad Constitucional, 33 (2014), 247.
} 


\section{Um paradoxo e um embuste no mercado cultural}

\section{Luís Couto Gonçalves*}

RESUMO: Neste texto abordamos um paradoxo e um embuste ligados ao mercado cultural. O paradoxo traduz-se na possibilidade de a utilização de dispositivos tecnológicos por parte dos titulares de direitos de autor na "sociedade da informação" poder impedir o acesso a informação que é livre na "sociedade analógica". O embuste reporta-se à inoperância do sistema de compensação equitativa aos autores pela cópia privada. Na realidade, os autores não recebem nada. A referida compensação não chega aos seus destinatários.

PALAVRAS-CHAVE: direito de autor - acesso a informação digital - cópia privada - compensação aos autores.

ABSTRACT: In this paper, the Author examines a paradox and a deception in the cultural market. The paradox lies within the possibility that, by using technological devices, copyright owners in the "information society" might prevent access to information that was open in the "analogical society". The deception relates to the ineffectiveness of the system that should fairly compensate authors for private copying. The truth of the matter is that authors receive nothing. The aforementioned compensation never reaches its destination.

KEYWORDS: copyright - access to digital information - private copying - compensation for authors.

* Professor Catedrático da Escola de Direito da Universidade do Minho. Membro da Comissão Diretiva do Centro de Estudos em Direito da União Europeia - CEDU. 


\section{I - Paradoxo}

\section{Proteção das medidas de caráter tecnológico e das informações para a gestão eletrónica de direitos}

Os dispositivos tecnológicos de proteção e de informação para a gestão dos direitos de autor e direitos conexos são regulados em Portugal, como nos restantes países da União Europeia, de acordo com os Tratados da Organização Mundial da Propriedade Intelectual - OMPI, de 1996 (respetivamente, arts. 11. ${ }^{\circ}$ e 12. ${ }^{\circ}$ do Tratado sobre Direito de Autor e arts. $18 .^{\circ}$ e $19 .^{\circ}$ do Tratado sobre Interpretações ou Execuções e Fonogramas) e a Directiva 2001/29/CE, de 22 de Maio, relativa à harmonização de determinados aspetos dos direitos de autor e direitos conexos na sociedade da informação (arts. 6. ${ }^{\circ}$ e $\left.7 .^{\circ}\right)^{1}$.

De acordo com os Tratados em causa, os dispositivos tecnológicos de proteção só podem ser tutelados se forem eficazes, utilizados por autores, artistas, intérpretes, executantes ou produtores de fonogramas, no exercício dos direitos de autor ou direitos conexos previstos nos Tratados ou na Convenção de Berna e restringirem atos não autorizados pelos titulares dos direitos em causa ou não permitidos por lei.

É ainda admitida a proteção dos dispositivos tecnológicos de proteção contra formas de utilização livres de acordo com o Direito de Autor e Direitos Conexos, não consentidas pelos autores, titulares de direitos de autor ou titulares de direitos conexos.

Com a transposição da Diretiva, os dispositivos tecnológicos de proteção e as medidas para a informação e gestão de direitos passaram a ser previstos no Código do Direito de Autor e Direitos Conexos (aprovado pelo DL n. ${ }^{\circ}$ 63/85, de 14 de março), no Título VI (arts. 217. a 228. ), sob a epígrafe "Protecção das medidas de carácter tecnológico e das informaçoes para a gestão electrónica de direitos".

A proteção das medidas de tecnológicas e dos sistemas de informação e gestão de dados insere-se na questão mais vasta da criminalização dos downloads não autorizados (nomeadamente, através das redes P2P) e das iniciativas para cortar

${ }^{1}$ Diretiva transposta para o direito português pela Lei 50/2004, de 24 de Agosto. 
o acesso à Internet (cfr. Projtos de Lei HADOPI, em França e Lei SINDE, em Espanha, PIPA e SOPAnos EUA e Tratado ACTA).

A ideia de base é a de que as redes internacionais de comunicações eletrónicas e a digitalização implicaram o acesso fácil do público em geral à informação, máxime, que circula na Internet, e também aos bens culturais protegidos pelo Direito de Autor e pelos Direitos Conexos. No entanto, este acesso maciço implica um enorme risco de violação à escala mundial das obras, prestações ou informação protegidas, nomeadamente, dado o fácil acesso a tais bens e à realização de cópias idênticas aos originais. Mas, a tecnologia, só por si, não é suficiente, uma vez que é sempre possível criar novas tecnologias destinadas a neutralizar as já existentes. Impõe-se a intervenção do sistema jurídico, para sancionar a neutralização dos dispositivos tecnológicos e dos sistemas de informação e gestão de dados.

O problema surge quando estas sanções impostas pelo Direito vão além do desejável, criando uma proteção hipertrofiada que coloca em causa os direitos dos legítimos utilizadores das obras, prestações e produtos protegidos. Cria-se, então, um paradoxo na própria Sociedade da Informação. Numa época em que praticamente toda a informação relevante passa por meios digitais, em particular pela Internet, verificase uma proteção excessiva, desproporcionada, dos titulares de direitos, que asfixia a circulação da informação e conduz os utilizadores e a sociedade em geral à infoexclusão.

É bom lembrar que os titulares de direitos de autor e dos direitos conexos nunca tiveram o direito de controlar o uso privado.

Os dispositivos tecnológicos e os sistemas de gestão e informação, aplicados indiscriminadamente, fazem com que se corra o risco sério, paradoxal e irónico, de a sociedade da informação se transformar numa sociedade pay-per-view, em que o acesso à informação e a bens culturais, livres na era analógica, têm que ser pagos, numa época em que a Internet - meio, por excelência, de comunicação pública permite um fluxo cada vez maior de informação digitalizada, à distância de um clique.

Só um adequado balanço entre os interesses dos titulares de direitos e dos utilizadores permite a promoção e difusão da cultura e da informação, imprescindíveis para que a evolução da sociedade se revele aceitável. Este equilíbrio, em nosso 
entender, está colocado em causa pela legislação vigente, que restringe em demasia a liberdade de utilização das criações intelectuais e da própria informação pelo público em geral. O livre acesso à informação, convém não esquecer, é a regra e não a exceção.

As medidas tecnológicas colocam questões interessantes, no plano do direito da concorrência e do direito do consumo, mas não podemos afastar-nos do objetivo central: a questão do desequilíbrio gerado pelas medidas tecnológicas e sistemas de informação e gestão de dados em desfavor do utilizador e do acesso livre aos bens culturais, para fins exclusivamente privados.

\section{Conclusão}

A proteção das medidas tecnológicas e dos sistemas de informação e gestão de dados introduzida no CDADC, por força dos Tratados da OMPI de 1996 e da transposição da Diretiva 2001/29/CE, é excessivamente ampla, possibilitando aos titulares de direitos ampliar os seus exclusivos de exploração para áreas tradicionalmente livres, pondo em causa o equilíbrio entre os titulares de direitos e os utilizadores, com prejuízo para estes últimos e para a sociedade em geral, afetando o desenvolvimento da cultura, da educação, do ensino, da liberdade de expressão e de informação e criando uma situação paradoxal: na sociedade da informação, em que a informação digitalizada está à distância de um clique, o utilizador fica menos protegido do que na era analógica. A legislação nacional, no entanto, é apenas o reflexo do que se passa a nível da União Europeia e fora dela (por exemplo, nos EUA) pelo que urge repensar toda esta matéria a uma escala internacional.

\section{II- Embuste}

\section{Compensação equitativa relativa à cópia privada}

A cópia privada é uma exceção ao direito exclusivo de reprodução que assiste aos titulares de direito de autor e de direitos conexos, e permite reproduzir uma obra sem prévia autorização dos titulares de direitos, para uso exclusivamente privado 
(caso especial), desde que não atinja a exploração normal da obra e não cause prejuízo injustificado dos interesses legítimos do autor, não podendo ser utilizada para quaisquer fins de comunicação pública ou comercialização (a chamada "regra dos três passos").

Esta exceção a um dos mais relevantes direitos patrimoniais contidos no direito de autor está consagrada no Código do Direito de Autor desde 1985 (art. 75. ${ }^{\circ}$, n. $^{\circ}$ 4), na senda da Convenção de Berna (art. 9. ${ }^{\circ}$, n. ${ }^{\circ}$ ), após a revisão de Estocolmo de 1967, e tem como condição a compensação dos titulares de direitos. Este princípio é afirmado também no art. 5. ${ }^{\circ}$, n. ${ }^{\circ} 5$ da Directiva (CE) 2001/29, do Parlamento e do Conselho, relativa à harmonização de certos aspetos do direito de autor e dos direitos conexos na sociedade da informação, que refere a cópia privada como uma das exceções ao direito de reprodução que podem ser adotadas pelos Estados-Membros, desde que os titulares de direitos obtenham uma compensação equitativa.

O regime jurídico da cópia privada destina-se, assim, a regulamentar a compensação equitativa, conforme dispõe o artigo $82 .^{\circ}$ do Código do Direito de Autor e dos Direitos Conexos.

Considerando que a cópia privada é, por definição, uma reprodução efetuada por utilizadores privados para fins privados, a sua realização não pode nem deve ser previamente autorizada, o que significa que não podem ser controladas as cópias efetivamente realizadas pelos utilizadores. Assim, os sistemas de compensação equitativa são sempre baseados na suscetibilidade de efetuar reproduções de obras protegidas, que resulta da plena utilização de equipamentos, aparelhos, suportes e outros dispositivos que permitam efectuar a referida reprodução. É relevante ponderar as funcionalidades de reprodução destes produtos, mas não a utilização efetiva dos mesmos, pois tal equivaleria a subverter os alicerces da cópia privada.

Em Portugal, a Lei que regulamentou pela primeira vez a cobrança da remuneração pela cópia privada foi publicada em 1998 (Lei n. ${ }^{\circ}$ 62/98, de 1 de Setembro), treze anos após a previsão da exceção no art. 81. ${ }^{\circ}$ al. b) do Código do Direito de Autor e dos Direitos Conexos de 1985. Em 2004 operou-se a revisão da Lei n. ${ }^{\circ}$ 62/98, por força da transposição da Diretiva 2001/29/CE. Ambos os 
regimes são minimalistas, pois reduzem a compensação a uma tarifa a incluir em equipamentos analógicos e contemplam apenas os CD e os DVD, numa era em que existem centenas de equipamentos e suportes que permitem a reprodução de obras protegidas, sendo que a utilização de alguns destes produtos, como sucede com os leitores de MP3 e MP4, apenas pode ser feita com recurso à reprodução de obras.

A Lei n. ${ }^{o}$ 49/2015, de 5 de junho, introduziu o novo regime legal da cópia privada alargando a compensação pela cópia privada aos equipamentos digitais.

$\mathrm{Na}$ prática, a cópia incide maioritariamente sobre obras literárias, musicais e audiovisuais e, dentro destas, as obras cinematográficas e séries televisivas. No mundo analógico da reprografia, predomina esmagadoramente a cópia da obra literária, sendo que, no seu âmago, são as obras técnicas, os livros científicos e escolares, o alvo privilegiado da cópia privada.

A arquitetura jurídica do sistema de cópia privada repousa na aplicação de uma quantia - sobre o preço de certos aparelhos e dos suportes de gravação (analógicos e digitais).

O poder de cobrança dessa quantia cabe à Associação para a Gestão da Cópia Privada - AGECOP (art. ${ }^{\circ}$ 6. ${ }^{\circ}$, n. $^{\circ} 1$, Lei n. ${ }^{\circ}$ 62/98 de 1 de setembro).

A AGECOP foi constituída em dezembro de 1998, no cumprimento do disposto no artigo 6. ${ }^{\circ}$ da Lei n. ${ }^{\circ}$ 62/98, na atual redação dada pela Lei n. ${ }^{\circ}$ 49/2015, de 5 de junho. Esta Associação é uma pessoa coletiva de utilidade pública, sem fins lucrativos, estando devidamente registada junto da Inspeção Geral das Atividades Culturais (IGAC).

A AGECOP é constituída por todas as entidades de gestão coletiva que em Portugal representam autores, artistas, intérpretes e executantes, produtores de fonogramas e videogramas, editores livreiros e editores de publicações periódicas, as quais se encontram também registadas junto da Inspeção Geral das Atividades Culturais.

O seu objeto consiste em cobrar, gerir e distribuir as quantias devidas a todos os titulares de direitos, visando compensar esses titulares dos danos patrimoniais sofridos com a aplicação da Lei da Cópia Privada, nos termos do artigo $6 .^{\circ}$ das referidas Leis e do artigo $82 .^{\circ}$ do CDADC. 
As quantias recebidas pela AGECOP, provenientes das compensações equitativas acima referenciadas, são afetadas de acordo com o estabelecido no artigo 7. ${ }^{\circ}$ da Lei n. ${ }^{\circ}$ 62/98, de 1 de setembro, na atual redação dada pela Lei n. ${ }^{\circ}$ 49/2015, de 5 de junho.

Os autores, artistas, intérpretes e executantes e mesmo os produtores protegidos por direitos conexos não podem, individualmente, aderir à AGECOP.

Desta forma, o autor, o artista intérprete ou executante, o produtor, se não integrar uma entidade de gestão coletiva, fica fora da estrutura associativa da cópia privada, sem possibilidade de influenciar as suas decisões, sobretudo, a mais importante de todas elas: a deliberação de distribuição dos resultados decorrentes da cobrança das quantias legais.

Embora seja o consumidor final a suportar o custo do sistema de cópia privada, vendo aumentar o preço dos produtos sobre os quais recai a aplicação da "quantia", o devedor jurídico é o fabricante nacional ou o importador dos aparelhos e suportes gravados por ela (art. 5. ${ }^{\circ}$, n. 2 a 6 da Lei n. ${ }^{\circ}$ 62/98), sobre o qual recai o dever de cobrança e de entrega à entidade gestora (AGECOP).

A receita arrecadada pela AGECOP deve ser distribuída num segundo momento aos beneficiários. E aqui é que o sistema não funciona.

Como existe, este sistema aumenta, a expensas do consumidor, as receitas da entidade de gestão coletiva (a AGECOP), que distribui o dinheiro sem um controlo adequado, deixando sem a compensação adequada os titulares de direitos cuja exploração económica sofre o impacto do exercício do uso privado, sobretudo, e muito em particular, aqueles, e são muitos, autores de obras científicas e técnicas - as mais copiadas - que não aderem à gestão coletiva.

\section{Conclusão}

O sistema de cópia privada, como existe em Portugal, tem o seu correspondente em várias outras ordens jurídicas da Europa continental desde que a Alemanha o aplicou na sua ordem interna na década de sessenta do século passado. O nosso 
Direito não consagra, pois, qualquer solução inovadora e está, pelo contrário, alinhado com a família jurídica da qual faz parte.

Mas é tempo de refletir sobre o falhanço do sistema de cópia privada no cumprimento do seu objectivo principal. O sistema atual é um embuste. Os autores não recebem nada! A dita compensação não chega ao seu destinatário. Fica numa teia burocrática de intermediários e entidades coletivas de gestão de direitos de autor e de direitos conexos. 


\section{A crise dos direitos autorais em 20 minutos, ou 10 páginas $\mathrm{A} 4$}

\section{Luiz Gonzaga Silva Adolfo*}

RESUMO: O modelo clássico de Direitos Autorais - construido no século XX, a partir da Convenção de Berna - mostrase em descompasso com a realidade social e tecnológica da contemporaneidade e, em vários pontos, fere regras e princípios constitucionais. Foi estudada a necessidade de atualiz̧ação da regulação jurídica dos direitos autorais, especificamente para novas e várias formas de utilização no ambiente digital. Utilizaram-se tratados e convenções internacionais na área dos Direitos Intelectuais, Constituição Federal brasileira e Lei de Direitos Autorais, bem como autoralistas que enfocam o problema e, particularmente, a Proposta de Análise dos Direitos de Autor no Ambiente Digital (SCCR/31/4), apresentada pelo Grupo de Países da América Latina e o Caribe (Grulac) na trigésima primeira sessão do Comitê Permanente sobre Direitos de Autor e Direitos Conexos da Organização Mundial da Propriedade Intelectual (Ompi), em Genebra, de 7 a 11 de dezembro de 2015. Como resultado, ratifica-se o esgotamento de um "modelo" de regulação nas esferas internacional e nacional e conclui-se pela emergência de um novo padrão de direitos autorais para o entorno digital.

PALAV RAS-CHAVE: direitos fundamentais - direitos autorais-Organização Mundial da Propriedade Intelectual - Grupo de Países da América Latina e o Caribe/Grulac-ambiente digital.

ABSTR ACT: The classical model of Copyright - built in the 20th century, (starting) from the Berne Convention - is out of step with the social and technological reality of contemporary times and offends constitutional rules and principles in several points. The need of updating of the legal regulation of Copyright has been studied specifically for the new and various forms of use in the digital environment. Studies are based on international treaties and conventions in the area of Intellectual Property Rights, as well as the Brazilian Federal Constitution, Copyright Law and also professionals specialized on authorship who focus on the problem and, particularly, the Proposal of Analysis of Copyright in the Digital Environment (SCCR/31/4), presented by the Group of Countries of Latin America and the Caribbean (Grulac) in the 31st session of the World Intellectual Property Organization (Ompi) Standing Committee on Copyright and Related Rights, in Geneva, from 7 to 11 December 2015. As a result, the depletion of a "model" for regulation in the international and national spheres is ratified and it is concluded that a new standard of Copyright to the digital surroundings constitutes an emergency.

KEYWORDS: fundamental rights - copyright - World Intellectual Property Organization - Group of Countries of Latin America and the Caribbean/Grulac - digital environment.

\footnotetext{
* Professor do Programa de Pós-Graduação em Direito da Universidade de Santa Cruz do Sul - UNISC e do Curso de Direito da Universidade Luterana do Brasil - ULBRA (Gravataí/RS).
} 


\section{Breve introdução, contextualizando a crise extrínseca dos Direitos Autorais}

Antes de encetar a análise do tema proposto, quero registrar minha gratidão à comunidade jurídica de Portugal, e o faço citando o trecho inicial da música Vira virou, dos músicos gaúchos Kleiton e Kledir. Quando estudava na Universidade de Lisboa na construção de minha tese de doutoramento, em janeiro e fevereiro de 2006, sempre lembrava de casa com saudades, e esta obra musical era "ponto de lembrança" do Brasil. Hoje, de Portugal. Registro aqui inicialmente, então, em especial por se tratar de um evento de Universidades do Brasil e de Portugal, a influência muito significativa que a doutrina portuguesa teve e tem em meu modo de pensar. Muito particularmente, anoto o referencial teórico do Professor José de Oliveira Ascensão.

Estas linhas consignam uma síntese do que o autor sustentou em Braga no dia 14 de novembro de 2016, tendo a honrosa companhia nos debates do Professor Luís Manuel Couto Gonçalves. O painel foi intitulado "Mercado cultural e proteção da criação intelectual e artística".

Inicialmente, convém delimitar a problemática que aqui será enfocada. Os Direitos Autorais surgiram definitivamente a partir da Revolução Francesa. Pesou, neste particular, a construção da liberdade de expressão como valor-vértice dos sistemas democráticos contemporâneos. A superação do ancièn regime da autorização necessária do soberano para publicações intelectuais (o nibil obstat) significou um incremento avassalador nas criações intelectuais ${ }^{1}$. E também no verdadeiro surgimento dos Direitos Autorais.

É bem verdade que anteriormente já se concretizavam algumas iniciativas,

\footnotetext{
${ }^{1}$ José de Oliveira Ascensão, Direito de Autor e Direitos Conexos (Coimbra: Coimbra, 1992), 682. O autoralista português analisa com a profundidade incomum que se vê em toda a sua obra as origens históricas da visão patrimonialista do Direito de Autor e dele como Direito de Propriedade. Decorreria, ideologicamente, no mau sentido da palavra, da Revolução Francesa, que revogou os privilégios e atribuiu direitos aos autores. Como não eram mais privilégios, passou a ser propriedade, tão valorizada no sistema póstomada da Bastilha. A própria ideia clássica das limitações como exceções está diretamente relacionada a isso, pois, se são exceções (ao direito de propriedade), não comportam interpretação extensiva, e daí decorreu uma valorização excessiva das prerrogativas do titular, tudo proibindo.
} 
inclusive legislativas, como o Estatuto da Rainha Ana, na Inglaterra, em 10 de abril de 1710 (o Copyright Act). No Brasil, a primeira norma legislativa de tutela aos Direitos Autorais surgiu em 1. ${ }^{\circ}$ de agosto de 1898, com a Lei n. ${ }^{\circ}$ 496, também conhecida como Lei Medeiros e Albuquerque. Em Portugal, a primeira Lei de Direitos Autorais data de 1851.

Em 1886 surgiu a União Internacional das Nações para a Proteção das Obras Literárias e Artísticas, mais conhecida atualmente como Convenção de Berna. Inicialmente faziam parte de Berna a Alemanha, Bélgica, Espanha, França, Inglaterra, Itália e Suíça; hoje são praticamente todos os países do mundo, com poucas exceções.

Se Berna teve o mérito de consagrar um documento internacional de tutela das criações intelectuais e sua universalização, ao mesmo tempo alguns fatores corroeram a proteção na forma consignada - e que ainda vige - dos Direitos Autorais. Eles foram erigidos em um patamar especificamente patrimonialista, que entendia os Direitos Autorais como direito de propriedade. Algo típico do Direito de cariz liberal-individualista do período oitocentista. E assim permanecerem incólumes por praticamente todo o século XX.

A Convenção de Berna, e com ela o parâmetro patrimonialista dos Direitos Autorais, espalhou-se mundo afora. No século XX surgiram outros Tratados, Acordos e Convenções Internacionais em torno da temática. E em 1967, com a Convenção de Estocolmo, foi criada a Organização Mundial da Propriedade Intelectual - OMPI, que tem sede em Genebra. Propalou-se então a expressão Direito da Propriedade Intelectual, abrangendo tanto as criações intelectuais especificamente artísticas ou estéticas (Direitos Autorais) como as de cunho técnico ou industrial (Direitos Industriais, também denominado Direito da Propriedade Industrial).

Também a partir deste período, particularmente em torno do último quartel do século passado, passou-se a vislumbrar de forma mais cristalina a crise do modelo posto em prática. Por primeiro, esta inadequação decorreu das novas tecnologias, que surgiram em profusão durante o século XX, davam-se nos suportes que aqui podem ser ditos como "tradicionais" ou clássicos, de propagação das criações intelectuais. Vale dizer, naquele período estava-se ainda no "mundo analógico". 
Esta realidade não é nova. Como pode ser visto em Hobsbawn, que refere, em parte de sua obra, a importância que teve a tecnologia e tiveram os meios de comunicação da construção da realidade do século passado, que introduziu a fantástica situação atual, na primeira metade de década do século XXI e do novo milênio. O historiador analisa detidamente a importância da cultura, estreitamente ligada aos Direitos Intelectuais, no século XX, no capítulo 6 de sua obra, intitulado “ As Artes de 1914-1945”, onde discorre sobre o surrealismo, o jazz, o cinema, ${ }^{2}$ os jornais ${ }^{3}$ e o rádio, que "transformava a vida dos pobres, e sobretudo das mulheres presas ao lar, como nada fizera antes"4.

Neste particular, a adoção de um sistema centralizado em "cópias" ou exemplares mostrava-se plausível. Vale dizer, o acesso de dava pelo meio físico.

A verdadeira revolução tecnológica ocorrida com o desenvolvimento maciço de novas e avançadas tecnologias na computação, com os softwares que praticamente nos permitem "fazer e acessar a tudo", mostra-se a cada dia mais acentuada, modificando vários aspetos do feitio humano de ser e de viver em sociedade ${ }^{5}$ Com o surgimento da internet pôs em xeque o modelo clássico de Direitos Autorais. E escancarava

\footnotetext{
2 "Não apenas se tornou essencial admirar essa arte, e notadamente sua maior personalidade, Charles Chaplin (a quem poucos poetas modernos de respeito deixaram de dedicar uma composição), como também os próprios artistas de vanguarda se lançaram na realização cinematográfica, mais especialmente na Alemanha de Weimar e na Rússia soviética, onde na verdade dominaram a produção"; e: "Contudo, ao contrário da imprensa, que na maioria das partes do mundo interessava apenas a uma pequena elite, o cinema foi quase desde o início um veículo de massa internacional. O abandono da linguagem potencialmente universal do filme mudo, com seus códigos testados de comunicação intercultural, com certeza muito fez.para internacionalmente familiar o inglês falado, e com isso ajudou a estabelecer a língua como o patoá global do fim do século". Eric Hobsbawn, Era dos Extremos: o breve século XX - 1914-1991 (São Paulo: Companhia das Letras, 1995), 182 e 193.

3 “A circulação de jornais nos EUA cresceu muito mais rápido que a população, dobrando entre 1920 e 1950. Nessa altura, vendiam-se entre 300 e 350 jornais por cada 100 bomens, mulheres e crianças de um país 'desenvolvido' típico, embora os escandinavos e australianos consumissem ainda mais publicações, e os urbanizados britânicos, talvez por ser sua imprensa mais nacional que local, compravam espantosos 600 exemplares para cada 1.000 habitantes". vd. United Nations Statistics Division, UN Statistical Yearbook 1948 (New York: United Nations Statistics Division, 1949). Hobsbawn, Era dos Extremos, 193.

4 "Ao contrário do cinema, ou mesmo da nova imprensa de massa, o rádio não transformou de nenbum modo profundo a maneira bumana de perceber a realidade. Não criou novos meios de ver ou estabelecer relações entre as impressões dos sentidos e as ideias (ver a Era dos Impérios). Era simplesmente um veículo, não uma mensagem. Mas sua capacidade de falar simultaneamente a incontáveis milhões, cada um deles sentindo-se abordado como indivíduo, transformava-o numa ferramenta inconcebivelmente poderosa de informação e de massa, como governantes e vendedores logo perceberam, para propaganda politica e publicidade". Hobsbawn, Era dos Extremos, 194-195.

${ }^{5}$ Pierre Levy, O que é virtual (São Paulo: Editora 34, 1997), 11.
} 
uma desarmonia, pois a moderna tecnologia da Sociedade da Informação ${ }^{6}$ pode ser definida como do "sim" (não somente permite, como oferece o acesso), enquanto a regulação dos Direitos Autorais na maioria das vezes significava um "não", negando o acesso a menos com autorização prévia e expressa do titular dos direitos em debate.

O segundo fenômeno que desestruturou a formatação jurídico-legislativa dos Direitos Autorais - e frise-se que não necessariamente nesta ordem, foi o constitucionalismo contemporâneo. As Constituições democráticas do mesmo período consagraram em seus textos princípios e regras que entraram em conflito se não direto na maioria das vezes, ao menos de forma indireta com este arquétipo.

No caso do Brasil, de democracia já tardia (1988), a Carta Política elencou vários direitos em decalagem com a democracia substancial que se pretende ver além de redigida efetivada em terrae brasilis. Basta mencionar aqui o direito à educação, à cultura, e à informação, para citar somente três deles.

Está posta a crise.

\section{A crise intrínseca do modelo vigente de Direitos Autorais}

Além da crise que foi denominada anteriormente extrínseca por se dar por fora do sistema autoralista legislado - mormente em decorrência do constitucionalismo contemporâneo, outra mostra-se bastante visível nos tempos atuais. Para seguir na mesma linha de raciocínio, pode-se designá-la como intrínseca.

Peculiarmente o diploma legislativo brasileiro (atualmente a Lei n. ${ }^{\circ}$ 9.610, de 19 de fevereiro de 1998) escancara incongruências internas que se repetem algumas há muitos instantes (basta ver que a lei vigente repetiu em boa dose os conceitos daquela anterior de 1973, que se fundou em boa base no que prescrevia a respeito o Código Civil de 1973 em seus artigos 649 a 673).

\footnotetext{
${ }^{6}$ Castells consagra em sua obra mais famosa, em três volumes resultantes de 12 anos de pesquisa, a expressão "Sociedade em Rede", caracterizada pela primazia da morfologia social sobre a ação social. Manuel Castells, A Era da Informação: Economia, Sociedade e Cultura: V. I: A Sociedade em Rede (8. ${ }^{a}$ ed., São Paulo: Paz e Terra, 2005), 565.
} 
Veja-se que, embora se tenham valores que estão consignados no Direito contemporâneo, como a função social do contrato (exemplificando), eles não aparecem de modo claro na Lei de Direitos Autorais brasileira. Poderia se argumentar que não precisaria, diante do diálogo das fontes, mas não é a realidade concreta vista na maioria dos tribunais brasileiros.

Muito particularmente a tensão do diploma autoralista de nosso país (e acreditase na grande maioria dos países) se dá na configuração daquelas que são chamadas limitações aos direitos autorais. Elas são a prescrição, também com esteio em Berna (a batizada Regra dos Três Passos ${ }^{7}$, ou Three-Step Test) de formas e casos de utilização das obras intelectuais que não prescindem de autorização prévia e expressa do autor ou do titular dos direitos patrimoniais de autor.

Elas são reguladas em número de 13 ou 14 no Brasil $^{8}$, e boa parte delas não se coaduna com a moderna tecnologia de compartilhamento de conteúdo on-line, além de entrarem em conflito com os ditames da Constituição Cidadã de 1988. Mire-se em um exemplo bastante cotidiano: quem adquire um CD de música - enquanto existirem os CDs musicais - em princípio e nesta visão conservadora não pode fazer uma cópia integral da obra para outro suporte, sob pena de estar ferindo direitos autorais. Ou quem providenciar cópia de um livro para escrever sua tese de doutorado ou dissertação de mestrado estará em idêntica situação.

Neste particular, registre-se que a atual Lei de Direitos Autorais brasileira regrediu com relação à anterior, pois a Lei n. ${ }^{\circ}$ 5.988, de 1973, possibilitava a efetivação de cópia de um exemplar, desde que feito pelo interessado e sem intuito de lucro. A lei vigente simplesmente revogou a cópia privada.

\footnotetext{
${ }^{7}$ Pedro João Fialho da Costa Cordeiro, "Limitacões e excepsões sob a "Regra dos Três Passos" e nas legislações nacionais: "diferenças entre o meio analógico e o digital", in Direito da sociedade da informação, org. José de Oliveira Ascensão (Vol. III, Coimbra: Coimbra, 2002), 211-219. Diz o autor que a Regra dos Três Passos se tornou tema "inultrapassável" quando se trata de matéria atinente às limitações e exceções do Direito Autoral, pois, primeiramente, foi o art. $13 .^{\circ}$ do TRIPs que estendeu seu âmbito de aplicação aos demais direitos exclusivos patrimoniais dos autores regulados na Convenção de Berna. Por segundo, foi o TODA (WCT) que, no seu art. $10{ }^{\circ}$, não somente fez idêntica extensão como sujeitou os novos direitos que criavam a idêntico princípio. Finalmente, na mesma linha se pronunciou o art. $16 .^{\circ}$ do TOEIF (WPPT) que, no seu n. ${ }^{\circ} 2$, indica a Regra dos Três Passos como ordenadora dos direitos que contempla. ${ }^{8}$ Aqui se remetendo aos arts. $46 .^{\circ}$ a $48 .^{\circ}$ da Lei de Direitos Autorais brasileira e às boas obras que tratam da crise das limitações entre nós, tanto no Brasil como em Portugal.
} 
E também aquilo que pode ser chamado de "ironia do sistema". Os Estados Unidos, a par de terem um padrão de Direitos Autorais excessivamente patrimonialista (O copyright consagrado a partir da Inglaterra, em vez do Droit D'Auteur do modelo continental, cunhado na França), construíram uma cláusula geral de limitações, o fair use, na qual o intérprete averigua no caso concreto se aquela utilização sob análise significa um "uso justo", ou não.

No Brasil, principalmente a partir da gestão do cantor Gilberto Gil no Ministério da Cultura, concretizaram-se discussões bastante acaloradas pela configuração de uma nova Lei de Direitos Autorais. Os embates se deram principalmente nos dois primeiros governos do Partido dos Trabalhadores, vale dizer nos dois governos "Lula". A iniciativa, que redundou em um Anteprojeto de Lei dos Direitos Autorais, acabou sepultada por pressões de vários atores econômicos desta complexa berlinda.

Paralelamente, conseguiu-se levar a cabo uma reforma parcial, na esfera da arrecadação coletiva dos direitos autorais, que redundou na Lei n. ${ }^{\circ}$ 12.853, de 2013', já que em solo verde e amarelo a atuação do Escritório Central de Arrecadação e Distribuição - ECAD é objeto de muitas polêmicas e críticas.

\section{O streaming e a "nova crise dentro da crise"}

Não bastassem as "crises" antes enfocadas, as tecnologias e iniciativas empresariais deste meado da década de 2010 trouxeram novos pontos de interrogação aos Direitos Autorais na atualidade. O streaming seguramente é o símbolo mais vivo desta situação.

Principalmente os titulares de obras musicais (autores, artistas, intérpretes e executantes) viram-se diante de uma realidade que fez desaparecer o anterior padrão. A execução musical não se dá mais precipuamente na forma de utilização de um suporte material, mas na internet ouvindo-se instantaneamente as músicas sem a "baixa” da obra.

\footnotetext{
${ }^{9}$. Lei n. ${ }^{\circ} 12.853$, de 14 de agosto de 2013 . Altera os arts. 5. ${ }^{\circ}, 68 .^{\circ}, 97 . .^{\circ}, 98 .^{\circ}, 99 .^{\circ}$ e $100 .^{\circ}$, acrescenta arts. 98. $.^{\circ}-\mathrm{A}, 98 .^{\circ}-\mathrm{B}, 98 .^{\circ}-\mathrm{C}, 99 .^{\circ}-\mathrm{A}, 99 .^{\circ}-\mathrm{B}, 100 .^{\circ}-\mathrm{A}, 100 .^{\circ}-\mathrm{B}$ e $109 .^{\circ}$-A e revoga o art. $94 .^{\circ}$ da Lei n. ${ }^{\circ} 9.610$, de 19 de fevereiro de 1998, para dispor sobre a gestão coletiva de direitos autorais, e dá outras providências. Acessado em 06 de março, 2017, http://www.planalto.gov.br/ccivil_03/_Ato 2011-2014/2013/Lei/ L12853.htm.
} 
Pesquisa publicada na França fez uma radiografia bastante elucidativa do mundo da música naquele país. Aqui se remete para ela, por ser assaz significativo, o gráfico que apresenta a evolução da distribuição musical por meio de streaming ${ }^{10}$.

Dados recentemente divulgados pela Revista Forbes dão conta de que as vendas de álbuns musicais nos Estados Unidos chegaram ao montante de 785 milhões de dólares no ano de 2000, um ano após Shawn Fanning e Sean Parker terem criado o Napster, que, na época, foi considerado uma "revolução" por permitir troca de músicas pela Internet. Em 2008, a soma dos negócios tinha enfraquecido 45\%. Depois disso, mesmo que as empresas fonográficas tenham diminuído o que denominam downloads ilegais, a indústria musical tem faturado por ano, na atualidade, em torno de 7,9 bilhões de dólares a menos que uma década e meia atrás ${ }^{11}$. Esses valores estrondosos já bem ilustram a agrura de um sistema, provocando, no mínimo, a mudança em alguns modelos de negócio neste domínio.

Tudo levou o Grupo de Países da América Latina e o Caribe (Grulac), na trigésima primeira sessão do Comitê Permanente sobre Direitos de Autor e Direitos Conexos da Organização Mundial da Propriedade Intelectual (Ompi), em Genebra, de 7 a 11 de dezembro de 2015, a apresentar Proposta de Análise dos Direitos de Autor no Ambiente Digital, lá tombado sob classificação SCCR $/ 31 / 4^{12}$.

Ao mesmo tempo, no contorno interno, o Ministério da Cultura do Brasil implementou consulta pública no início de 2016 para perquirir a respeito da possibilidade de arrecadação de direitos autorais pelas entidades arrecadadoras (principalmente o Ecad), de utilização de obras no ambiente digital, mormente por meio do streaming ${ }^{13}$.

\footnotetext{
${ }^{10}$ SNEP - Syndicat National de l'Edition Phonographique, L'économie de la production musicale (Neuillysur-Seine: Souce SNEP, Edition 2015).

${ }^{11}$ Zack O’Milley Greenburg, “Como as gravadoras estão se apoderando da multibilionária revolução digital", Forbes Brasil, Negócios, dezembro 18, 2015. Embora no início, como relata Stephen Witt, Como a música ficon grátis: o fim de uma indústria, a virada do século e o paciente zero da pirataria (Rio de Janeiro: Intrínseca, 2015), 54-55, 83-86, as gravadoras musicais tenham menosprezado o poder do streaming. 12 "SCCR/31/4 - Proposal for Analysis of Copyright Related to the Digital Environment", WIPO - World Intellectual Property Organization, acessado em fevereiro 6, 2016, http://www.wipo.int/ meetings/en/details. jsp?meeting_id=35598.

13 “Consulta Pública para a redação de Instrução Normativa para cobrança de Direitos Autorais no
} 
Na seara de atuação do Poder Judiciário, uma decisão do Superior Tribunal de Justiça-STJ, do início de 2017, tenta por um foco de luz na controvérsia. No Recurso Especial (REsp) n. ${ }^{\circ}$ 1.559.264/RJ, tendo como relator o Ministro Ricardo Villas Bôas Cueva, o STJ decidiu que de fato cabe a cobrança de direitos autorais pelo ECAD na divulgação de obras musicais pelo sistema de streaming. O voto vencedor, do relator, tem mais de 20 páginas e faz diversos conceitos em torno do que se retrata ${ }^{14}$.

Em síntese, avaliou-se a conformação ou não da realidade da "execução pública" na disponibilização de músicas via streaming. A exigência de execução pública até aqui tem sido considerada o fator central para a cobrança dos direitos autorais em nosso país.

Houve embargos de declaração de ambas as partes, e enquanto se alinhavam estas linhas (final de fevereiro e início de março de 2017), a situação ainda soa como não definitiva.

\section{Conclusão}

Este texto pretendeu demonstrar os aspetos de uma crise que assola os Direitos Autorais há alguns anos e, simultaneamente, enfatizar o que pode existir "de novo" numa crise que parece ser definitiva.

A criatividade artística sempre acompanhou os seres humanos. Ao mesmo tempo que a inventividade, característica mais própria dos Direitos Industriais. No entanto, demorou muito para que surgisse um "direito" de autor. Isso de concretizou de forma mais clara a partir ou em torno da Revolução Francesa.

E foram concebidos os Direitos Autorais naquele período oitocentista como "direito de propriedade". E assim passaram a maior parte do século passado.

Os maiores pontos de rutura do sistema começaram a surgir no final do século XX. Primeiramente, em decorrência da construção do constitucionalismo

Ambiente Digital", Ministério da Cultura, DDI - Diretoria de Direitos Intelectuais, acessado fevereiro 15, 2016, http://culturadigital.br/ gcdigital.

${ }^{14}$ Superior Tribunal de Justiça, Segunda Secão, Recurso Especial n. 1559264, Relator Ministro Ricardo Villas Bôas Cueva, julgado em 8 de fevereiro 2017. 
contemporâneo, cujos valores democráticos muitas vezes conflitam com o protótipo proprietarista dos Direitos Autorais. Num segundo patamar - e registre-se que ambos os fatores não andam dissociados - em decorrência da Revolução Tecnológica verificada na Sociedade da Informação.

Concebidos em boa parte como direitos do "não", os Direitos Autorais de hoje estão estabelecidos na sociedade cuja técnica diz "sim" permanentemente. Ou seja, "compartilhamento" é a grande palavra e a realidade dos tempos modernos.

Há, portanto, verdadeiro conflito desta angulação dos Direitos Autorais clássicos com as realidades jurídicas e tecnológicas de nossa época.

A nova crise (ou a "crise dentro da crise", como aqui consignado) deu-se a partir da realidade do streaming. Vinculado inicialmente de forma mais cabal às obras musicais, atinge outras áreas dos Direitos Autorais, nas quais não se necessita do exemplar físico para ter acesso às obras.

As discussões deste tema são efetuadas nos âmbitos do Direito Internacional Público (aqui se referiu o círculo da OMPI), dos governos, dos legislativos nacionais, e principalmente pela classe artística. Esta - particularmente no que tem a ver com as obras musicais - reclama incessantemente das novas formas de universalização do acesso às obras. Especialmente que pouco ganham em termos pecuniários com suas obras.

Novos capítulos virão. Aguardemos. 


\title{
A transparência nos interesses que envolvem as relações de mercado e a administração pública
}

\author{
Mara Ahlert* \\ RESUMO: Tendo em vista o crescimento da improbidade administrativa que ocorre na administração pública, faz-se \\ necessário que haja uma revisão nas legislações que tratam das relações que envolvem o setor público e o privado. $O$ artigo \\ prevê que é necessário que haja um controle dos gastos públicos, com intuito de evitar práticas corruptivas no desvio de \\ verbas públicas, destacando que a corrupsão é um problema social, político e institucional. O estudo sustenta que através \\ da transparência e participação social da gestão pública brasileira poderia haver uma redução nas práticas corruptivas, \\ motivo pelo qual o Estado deve apurar as causas e circunstâncias dos comportamentos corruptivos, sob pena de estar o ente \\ público conivente com este fenômeno. É necessário que se avaliem medidas que favoreçam o controle social da gestão pública \\ como forma de combater o fenômeno da corrup̧cão que vigora em nosso país, e resulta no enriquecimento ilícito de agentes \\ públicos de um lado e administradores de empresas privadas de outro lado.
}

PALAVRAS-CHAVE: Administração pública - controle social - corrupção - empresa privada - transparência.

ABSTRACT: In view of the growth of administrative impropriety that occurs in the public administration, it is necessary to have a revision in the legislation that deals with the relations involving the public and private sectors. The article states that there is a need to control public spending in order to avoid corruptive practices in the diversion of public funds, pointing out that corruption is a social, political and institutional problem. The study maintains that through the transparency and social participation of Brazilian public management there will be a reduction in corruptive practices, which is why the State must investigate the causes and circumstances of corruptive behavior, otherwise the public entity will be conniving with this phenomenon. It is necessary to evaluate measures that favor the social control of public management as a way to combat the phenomenon of corruption that is in force in our country, and results in the illicit enrichment of public agents on the one hand and administrators of private companies on the other.

KEYWORDS: public administration - social control - corruption - private company - transparency.

* Mestranda em Direito na Universidade de Santa Cruz do Sul - UNISC. 


\section{Considerações iniciais}

Da forma que a corrupção vem tomando proporções, ela não está simplesmente corroendo o erário público, ela está destruindo a confiança do cidadão no poder estatal, gerando um impacto negativo em todas as áreas da sociedade.

O objetivo deste artigo é tratar da corrupção, bem como, analisar se de alguma maneira o controle social da educação poderá ser uma das formas no combate a práticas corruptivas que ocorrem nos mais diversos segmentos dos setores públicos.

Os comportamentos corruptivos estão cada vez mais presentes nas instituições e nas relações sociais, ocasionando variadas situações que envolvem a corrupção, tais como subornos, concessão de vantagem para obter vaga em hospital público, desvio de verba destinada a obras públicas, entre outras.

Desta forma, o desvio sistemático de recursos públicos, que seriam aplicados na melhoria da sociedade, condena não só as cidades, mas também o país, ao subdesenvolvimento econômico e social crônicos. Por isso, o combate à corrupção nas administrações públicas deve ser um compromisso de todas as pessoas que se preocupam com o desenvolvimento social e querem construir um país melhor para si e seus filhos.

Por fim, o estudo aponta a necessidade da transparência para o controle institucional no combate da corrupção, a fim de que a prática da corrupção perpetrada por agentes públicos, cujo interesse privado se sobrepõe ao interesse público, seja punido.

\section{O fenômeno da corrupção na sociedade brasileira}

A corrupção perpassa a história da sociedade humana, independente de época ou região, razão pela qual é possível afirmar que é um fenômeno universal e que tem se intensificado com o aumento dos fluxos de pessoas, capital e informação, facilitado pelos avanços tecnológicos ${ }^{1}$.

${ }^{1}$ Neste sentido, cfr. Giovanni Quaglia, "Por uma cultura anticorrupção”, Revista do Ministério Público do 
A corrupção em um país está intimamente ligada a fatores como a cultura e a educação de sua população. Podemos citar o Brasil, no qual existe um estado de anomia social.

Observando esse ponto, de fato, a cultura da corrupção no Brasil parece que, se não foi nascida, pelo menos foi difundida pela classe dos “bomens públicos". Políticos e administradores públicos desrespeitam a lei tranquilamente, praticam sucessivos atos de improbidade, e a sociedade, historicamente, não os assistiu serem punidos nem na esfera administrativa nem na esfera judicial criminal ou civil2

As práticas corruptivas são um problema de grau e extensão, pois encontra variação no tempo e no espaço. A experiência mostra que ela pode ser reduzida, se nunca eliminada, e que a maioria dos atos corruptos não são crimes de paixão, mas crimes calculados ${ }^{3}$.

Funcionários públicos não são corruptos todo o tempo, mas em cada oportunidade, de modo que é razoável afirmar que um funcionário pratica uma ação corrupta quando, a seu juízo, ela lhe proporcionará mais benefícios do que custos.

Assim, entre outras medidas, uma punição mais severa pode ser útil para a diminuição da corrupção. A escolha da pena poderia ser adotada com olhos voltados para a "cultura de corrupção". Quando a corrupção é sistemática, cinismo e alienação são a regra.

O sucesso com campanhas anticorrupção sugerem que a pena severa em um "peixe grande" é um modo de começar a subverter aquela cultura. Esse "peixe grande" deve ser um homem público importante, não devendo a punição denotar jogo político ${ }^{4}$.

A realidade brasileira atual aponta que a corrupção está inserida em todos os segmentos da sociedade e do Estado, sendo necessário o aprimoramento de mecanismos de identificação e prevenção das práticas corruptivas.

DF e Territórios. 4,7 (março/abril de 2007).

${ }^{2}$ Neste sentido, cfr. Marco Aurélio Lustosa Caminha, "A corrupção na Administração Pública no Brasil", Revista Jus Navigandi 8,176 (29 dez. 2003).

${ }^{3}$ Neste sentido, cfr. Robert Klitgaard. A corrupscão sob controle, (Trad. Otávio Alves Velho. Rio de Janeiro: Jorge Zahar Editor Ltda, 1994), 1233

${ }^{4}$ Cfr. Robert Klitgaard. A corrup̧̣ão sob controle, 123. 
A corrupção põe em risco a democracia, pois contamina a relação entre o Estado e os cidadãos, que passam a duvidar da credibilidade das instituições. Assim, resta evidente que a corrupção esvazia os cofres públicos e, por consequência, a impunidade vigora nos tempos atuais, tendo em vista que a legislação é tímida sobre o tema.

Dessa forma, o Estado vem perdendo vergonhosamente a guerra contra a corrupção, pois as práticas corruptivas estão inseridas no contexto da administração pública no Brasil, não sendo a punição a única forma de solucionar o problema. Embora seja necessária uma punição mais severa para coibir práticas ilícitas, faz-se necessário desenvolver mecanismos de identificação e prevenção.

A corrupção pode ser de menor monta, quando ocorre sob a forma de propina, onde o funcionário público recebe vantagem em troca de algum favor, ou de grande monta, na qual há processos de licitação, contratações entre Administração Pública e grandes empresas.

Urge que se reprima o fenômeno da corrupção que assombra o desenvolvimento do Brasil. É essencial que se promova a educação para o exercício da cidadania através de condutas éticas e sociais, transformando os cidadãos em coautores da construção de um país melhor e mais justo para todos.

\section{Transparência e o combate às práticas corruptivas}

Estamos vivendo um momento singular na história do Brasil, pois em decorrência da Operação Lava-Jato, a qual visa combater a corrupção, diversos cidadãos e políticos conhecidos nacionalmente estão sendo investigados e presos, pois estão envolvidos em escândalos que envolvem o dinheiro público ${ }^{5}$.

Segundo previsão no texto constitucional brasileiro, as entidades públicas têm o dever de promover a transparência de sua administração e a sociedade tem o

\footnotetext{
${ }^{5}$ Neste sentido, cfr. “Transparência e combate à corrupção: é imperativo continuar", Rejane Romano, acessado em dezembro 15, 2017, http://www3.ethos.org.br/cedoc/transparencia-e-combatecorrupcao-e-imperativo-continuar.
} 
direito ao acesso e o acompanhamento da administração pública, como forma de consolidação da cidadania.

Para se conseguir obter mudanças na participação social há a necessidade de transformações institucionais que garantam acessibilidade e transparência da gestão ${ }^{6}$.

A transparência proporciona um ambiente de análise e reflexão, mas para isso é necessário que os gestores públicos descortinem suas tomadas de decisões e divulguem-nas livremente nos meios de comunicação acessíveis à população, não permitindo que suas informações fiquem restritas a alguns servidores e assessores.

De forma breve, a transparência na Administração Pública tem como objetivo ampliar o compromisso mútuo entre os cidadãos e o Poder Público, fortalecendo as relações democráticas e incorporando a democracia participativa.

Os princípios da transparência e da democracia participativa são necessários para se atingir a boa governança, a qual irá tomar medidas no combate à corrupção no setor público.

Certamente a corrupção é um problema enfrentado por diversos países, em especial aqueles em que a democracia passou a vigorar recentemente e que buscam maior eficiência nos órgãos governamentais, por mais investimentos econômicos e igualdade social da população.

Ao dificultar ou impedir a informação a alguma pessoa, o gestor público fortalece seu poder e confirma o seu autoritarismo. A transparência é solução encontrada para coibir esse tipo de conduta autoritária. A divulgação das ações contribui para a análise crítica da gestão pública.

A participação social tem a intenção de pressionar as instituições a terem mais agilidade e transparência, bem como, propiciar um suporte de legitimidade às decisões de direção ${ }^{7}$. Trata-se de instância política que envolve uma comunidade de usuários de um serviço público.

\footnotetext{
${ }^{6}$ Neste sentido, cfr. Pedro Jacobi, "Educação ambiental, cidadania e sustentabilidade", Caderno de Pesquisa [online] 118 (2003), 189-206.

${ }^{7}$ Neste sentido, cfr. Alexandre Kalil Pires, Gestão pública e desenvolvimento (Vol. 6, Brasília: Ipea, 2011).
} 
A entidade ao dar transparência de seus dados, abre espaço para futuras reivindicações sociais que visem a um maior detalhamento e à ampliação das informações disponibilizadas. Por isso, há a necessidade do maior envolvimento social na gestão das políticas públicas.

A informação dotada de clareza e de fácil compreensão para o cidadão comum é peça fundamental para o controle social. A transparência e participação social são conceitos indissociáveis, interdependentes e intercambiáveis.

É este novo cidadão que vai contrapor à burocracia estatal demandas de participação e colaboração mais direta e intensiva, redimensionando os termos do contrato social firmado no âmago da Democracia Representativa. Eis que se ampliam radicalmente os espaços públicos de participação e decisões sociais, para além dos momentos estagnados do sufrágio e dos mandatos, rompendo de vez à noção tecnocrática de gestão estatal-burocrática?.

Por fim, resta claro que o crescimento da transparência auxilia no envolvimento de diferentes classes sociais no acompanhamento da gestão pública. É sabido que a divulgação de dados exclusivamente para grupos restritos inibe o seu caráter de promoção da democracia, ferindo os princípios constitucionais da legalidade, impessoalidade, moralidade, publicidade e eficiência. Isto acarretará no desenvolvimento de um ambiente propício a condutas ilícitas e corruptas.

\section{Fortalecimento do controle social no enfrentamento da corrupção no setor público e privado}

É sabido que as práticas corruptivas entre agentes públicos e agentes privados ocorre há longa data e o objetivo final é a obtenção de vantagens ilícitas para ambos os lados, ou seja, há uma parceria com a intenção de burlar a legislação para obter vantagem indevida.

\footnotetext{
${ }^{8}$ Neste sentido, cfr. José Luiz Lins dos Santos, Transparência Regulatória e Controle Social Experiências Exitosas em Regulação na América Latina e Caribe (Brasília:Presidência da República, 2012).

${ }^{9}$ Neste sentido, cfr. Rogério Gesta Leal, Patologias corruptivas nas relações entre Estado, Administração Pública e Sociedade: causas, consequências e tratamentos (Santa Cruz do Sul: Edunisc, 2013), 187.
} 
O noticiário está abarrotado que situações que relatam o envolvimento de empresas privadas com gestores públicos com o intuito de praticar atos corruptos.

A corrupção tem de ser punida, mas fundamentalmente, e antes de tudo, prevenida com medidas eficazes de detecção a serem implementadas pelos EstadosPartes, em decorrência dos prejuízos e danos irreversíveis - notadamente no âmbito da moralidade pública e desgaste das instituições democráticas atingidas na espécie ${ }^{10}$.

Dessa forma, o Brasil, através da Lei 12.846/13, denominada Lei Anticorrupção, impõe legalmente que as empresas do setor privado adotem o Programa de Integridade, cuja pretensão é coibir práticas corruptivas contra a Administração Pública, nacional ou estrangeira. Estes programas servem como ferramentas de credibilidade e transparência, para salvaguardar o interesse público de contratação de empresas privadas idôneas para servirem à coletividade.

É inegável a relevância do papel desempenhado pelo sistema de controle da Administração Pública no mundo contemporâneo. A crescente sintonia nas relações dos órgãos de controle e a sociedade estão contribuindo para estimular a fiscalização dos gastos públicos, aumentando a efetividade das políticas sociais, bem como dos próprios serviços que são prestados pelo Estado ${ }^{11}$. Esse esforço vem se tornando essencial para o fortalecimento da cidadania e da democracia.

Diante da transcrição acima referida, observa-se a necessidade de controlar as atividades exercidas na Administração Pública, como forma de coibir a má aplicação do dinheiro público, bem como, fazer com que as políticas públicas sejam efetivadas de acordo com o real interesse da sociedade.

O controle das práticas corruptivas na Administração Pública poderia ocorrer através de uma democracia mais participativa e deliberativa que envolva a sociedade civil como protagonista.

\footnotetext{
${ }^{10}$ Cfr. Rogério Gesta Leal. Patologias corruptivas, 132.

${ }^{11}$ Neste sentido, cfr. "Transparência, controle de contas públicas e combate à corrupção", José Matias Pereira, acessado em dezembro 15, 2017, http://www.tce.ce.gov.br/downloads/Controle_Cidadao/ f9_-_controle_cidadao.pdf.

José Matias Pereira, "Transparência, controle de contas públicas e combate à corrup̣ção", Controle Cidadão $9^{\circ}$ (2014).
} 
A corrupção do corpo político, significando impedimento, a restrição ou o desvirtuamento da vontade soberana do povo, introduz o reino dos privilégios ao acesso a direitos e a deveres e devasta o interesse público pela força do privatismo e do particularismo ${ }^{12}$.

Há alguns anos existe no Brasil um ciclo de participação por parte da cidadania, são os considerados fóruns híbridos e interativos, que ocorrem entre instituições públicas, privadas ou representações sociais, onde o assunto corrupção ultrapassa as fronteiras burocráticas do Estado e vai ao encontro das instâncias deliberativas da sociedade civil, como ator e protagonista, sujeito de direitos e deveres ${ }^{13}$.

É de forma urgente que se deve buscar um conhecimento mais elaborado sobre a corrupção e sobre as suas consequências no que tange ao enriquecimento pessoal decorrente dela, pois há ausência de informações precisas e indicadores confiáveis sobre níveis estatísticos que apontem onde ela opera, e em quais segmentos há maior incidência de práticas corruptivas.

Devemos gerar mecanismos capazes de demonstrar quais os fatores que mais facilitam a prática corruptiva e como a mesma se difunde. Talvez uma Democracia mais participativa e deliberativa responda de forma mais legítima a este problema da corrupção, envolvendo a Sociedade Civil como protagonista primordial à sua ocorrência ${ }^{14}$.

Há diversos mecanismos para o controle das atividades públicas e privadas, devendo-se adotar com ênfase as medidas cabíveis, inclusive a intervenção do Poder Judiciário quando necessário, com a finalidade de concretizar os mandamentos constitucionais eleitos pela sociedade.

A corrupção no Brasil afeta a livre concorrência quando da contratação com a Administração. As regras do procedimento licitatório foram criadas para garantir, entre tantos outros princípios, o da ampla concorrência, visando maior eficiência

\footnotetext{
${ }^{12}$ Neste sentido, cfr. Juarez Guimarães “Sociedade Civil e corrupção: crítica à razão liberal”, in Corrupção e sistema politico no Brasil, org. Leonardo Avritzer e Fernando Figueiras (Rio de Janeiro: Civilização Brasileira, 2011).

${ }^{13}$ Cfr. Rogério Gesta Leal. Patologias corruptivas, 81.

${ }^{14} \mathrm{Cfr}$. Rogério Gesta Leal. Patologias corruptivas, 81.
} 
e economicidade nos gastos públicos. Porém, a corrupção pode obstruir a livre competição ao favorecer uma empresa específica, não por conta de sua qualidade, mas por interesses particulares. Ocorre, não várias vezes, que diversas empresas não conseguem competir em licitações públicas porque há esquemas já instalados de favoritismo e corrupção.

Urge um comportamento ativo por parte do Estado para apurar as causas e circunstâncias dos comportamentos corruptivos, sob pena de estar o ente público conivente com este fenômeno.

\section{Considerações finais}

Atualmente a corrupção na Administração Pública é um tema que está presente diariamente nos meios de comunicação, sugerindo que possivelmente ela seja uma das principais causas da desigualdade social no Brasil.

Diante deste contexto, sob a ótica da transparência nas relações entre os setores público e privado, os gestores públicos devem estar atentos aos dispositivos legais, pois administrar um ente público visa o bem estar comum da coletividade administrada, atentando-se que somente são permitidos atos explicitados na legislação.

A transparência na gestão pública amplia o compromisso mútuo entre os cidadãos e o Poder Público e fortalece as relações democráticas. Nesse diapasão, é importante que a gestão pública esteja assessorada por ferramentas que permitam à sociedade o acompanhamento da efetivação do controle social.

A transparência na gestão pública ocorre quando os governos disponibilizam os dados por iniciativa própria, firmando assim uma postura proativa e esperada pela sociedade. Para tanto, são utilizadas ferramentas que permitem o acompanhamento da efetivação do controle social, com clareza nas ações, deixando a população informada dos gastos e investimentos público.

Assim, reitera-se a importância da busca por soluções através do controle social para coibir a corrupção, que por sua vez está conectada com a filosofia, ética, história, política, economia, sociologia e direito, razão pela qual merece amplo e profundo 
estudo investigativo, que abordará os seus diversos segmentos, tais como improbidade administrativa, lavagem de dinheiro, crimes contra economia popular, entre outros.

Através dos comportamentos corruptivos de alguns indivíduos, tanto do setor público quanto do setor privado, a prática corruptiva poderá atingir os direitos fundamentais garantidos constitucionalmente, demonstrando que o Estado é responsável por evitar essa prática, como por exemplo, a conduta na qual um cidadão paga suborno para obter vaga em hospital público para seu filho, o político que desvia verbas públicas destinadas à pavimentação e manutenção de estradas, entre outros.

O estudo demonstra a importância sobre a discussão do controle social, da transparência pública, do acesso à informação e das ações de combate à corrupção no Brasil, destacando que essas questões são relevantes, pois servem para consolidar a democracia no país e fortalecer os mecanismos de participação do cidadão nos assuntos do Estado.

Ao final, evidencia-se a importância deste tema, pois quanto mais ele será estudado e enfrentado, acredita-se que tanto mais surgirão formas eficazes para se detetar e implementar medidas punitivas e de prevenção ao fenômeno da corrupção. Portanto, cabe ao Estado uma desacomodação e o enfrentamento das diversas formas de corrupção, a qual causa inúmeros prejuízos aos cofres públicos. 


\title{
Integração judiciária e tutela jurisdicional dos interesses económicos e sociais
}

\author{
Marco Carvalho Gonçalves*
}

RESUMO: O presente texto procura analisar os principais desafios que se colocam atualmente em matéria de integração judiciária e proteção da tutela jurisdicional efetiva, particularmente no que diz respeito à competência judiciária, reconhecimento e execução de decisões em matéria civil e comercial, bem como à citação e notificação de atos judiciais e extrajudiciais. Assim, partindo da identificação prévia de alguns problemas que se colocam no domínio da proteção da segurança jurídica, serão apresentadas propostas de alterações legislativas no sentido de se garantir de forma plena a integração judiciária e a tutela jurisdicional efetiva na União Europeia.

PALAV RAS-CHAVE: cooperação judiciária - reconhecimento e execução de decisões - citação e notificação de atos judiciais e extrajudiciais - obtenção de provas - cobrança de dividas - assistência judiciária - princípio da territorialidade.

ABSTR ACT: This text seeks to analyze the main challenges currently facing judicial integration and the effective judicial protection, in particular as regards jurisdiction and the recognition and enforcement of judgments in civil and commercial matters, as well as citation and notification of judicial and extrajudicial acts. Therefore, starting from the preliminary identification of some problems regarding the legal security protection, will be made proposals for legislative changes to ensure full judicial integration and effective judicial protection in the European Union.

KEYWORDS: judicial cooperation - recognition and enforcement of decisions - citation and notification of judicial and extrajudicial acts - taking of evidence - European order for payment procedure - judicial assistance - principle of territoriality.

\footnotetext{
* Professor da Escola de Direito da Universidade do Minho. Membro Doutorado do Centro de Estudos em Direito da União Europeia - CEDU.
} 


\section{Nota introdutória}

Nos últimos anos, temos vindo a assistir a um crescente esforço de integração europeia ao nível da cooperação judiciária entre os diferentes Estados-Membros, tendo em vista a tutela jurisdicional efetiva.

$\mathrm{Na}$ verdade, a consagração do princípio da livre circulação de pessoas, bens e serviços, enquanto pilar fundamental da União Europeia, exige a adoção de medidas que, sob o prisma da interjurisdicionalidade, promovam a interação entre as diferentes ordens jurisdicionais. Com efeito, essa liberdade de circulação potenciou o surgimento de litígios transfronteiriços que, pela sua complexidade, decorrente, desde logo, da sua conexão com diferentes ordens jurídicas, impôs, num primeiro plano, a implementação de instrumentos de cooperação judiciária e de integração europeia em matéria civil e comercial.

Neste particular, os principais desafios que se colocam atualmente em matéria de integração judiciária traduzem-se, fundamentalmente, na facilidade de acesso à Justiça, na definição da competência internacional dos tribunais dos diferentes Estados-Membros, na cooperação judiciária em matéria processual civil e no reconhecimento e execução de decisões judiciais.

Com efeito, à luz do art. 81. ${ }^{\circ}$, n..$^{\circ}$ 1, do TFUE, a União Europeia deve desenvolver "uma cooperação judiciária nas matérias civis com incidência transfronteiriça, assente no princípio do reconbecimento mútuo das decisões judiciais e extrajudiciais", sendo que essa cooperação "pode incluir a adoção de medidas de aproximação das disposições legislativas e regulamentares dos Estados-Membros".

Por sua vez, de acordo com o n. ${ }^{\circ} 2$ da referida disposição normativa , o Parlamento Europeu e o Conselho, quando tal seja necessário para o bom funcionamento do mercado interno, devem adotar medidas destinadas a assegurar, nomeadamente, o reconhecimento mútuo entre os Estados-Membros das decisões judiciais e extrajudiciais e a respetiva execução, a citação e notificação transfronteiriça dos atos judiciais e extrajudiciais, a compatibilidade das normas aplicáveis nos EstadosMembros em matéria de conflitos de leis e de jurisdição, a cooperação em matéria de 
obtenção de meios de prova, o acesso efetivo à justiça, a eliminação dos obstáculos à boa tramitação das ações cíveis, promovendo, se necessário, a compatibilidade das normas de processo civil aplicáveis nos Estados-Membros, o desenvolvimento de métodos alternativos de resolução dos litígios e o apoio à formação dos magistrados e dos funcionários e agentes de justiça.

No prosseguimento desse desiderato, assumem especial destaque no âmbito da integração judiciária a definição de regras uniformes em matéria de competência, reconhecimento e execução das decisões judiciais ${ }^{1}$, citação e notificação transfronteiriça de atos judiciais e extrajudiciais ${ }^{2}$, obtenção de provas ${ }^{3}$, cobrança de dívidas $^{4}$ e assistência judiciária 5 .

\section{Competência judiciária, reconhecimento e execução de decisões}

\subsection{Generalidades}

Um dos domínios mais sensíveis em matéria de integração judiciária e tutela jurisdicional efetiva diz respeito à definição de normas comuns em matéria de competência judiciária, reconhecimento e execução de decisões. $\mathrm{Na}$ verdade, o direito de acesso aos tribunais, bem como o direito de obtenção de uma decisão em prazo razoável no âmbito de um litígio transfronteiriço, impõe a adoção de regras

\footnotetext{
${ }^{1}$ Regulamento (UE) n. ${ }^{\circ}$ 1215/2012, do Parlamento Europeu e do Conselho, de 12 de dezembro de 2012.

${ }^{2}$ Regulamento (CE) n. ${ }^{\circ}$ 1393/2007 do Parlamento Europeu e do Conselho, de 13 de novembro de 2007. ${ }^{3}$ Regulamento (CE) n. ${ }^{\circ} 1206 / 2001$, do Conselho, de 28 de maio de 2001.

${ }^{4}$ Vide, a este propósito, o Regulamento (CE) n. ${ }^{\circ}$ 1896/2006 do Parlamento Europeu e do Conselho, de 12 de dezembro de 2006, que cria um procedimento europeu de injunção de pagamento, o Regulamento (CE) n..$^{\circ}$ 861/2007, do Parlamento Europeu e do Conselho, de 11 de julho de 2007, que estabelece um processo europeu para ações de pequeno montante e procura simplificar e acelerar os procedimentos de natureza civil ou comercial em que o valor do pedido não exceda a quantia de 2000 euros, bem como o Regulamento (CE) n. ${ }^{o}$ 805/2004 do Parlamento Europeu e do Conselho, de 21 de abril de 2004, que cria o título executivo europeu para créditos não contestados

${ }^{5}$ Diretiva (CE) 2002/8 do Conselho, de 27 de janeiro de 2003, referente à melhoria do acesso à justiça nos litígios transfronteiriços, através do estabelecimento de regras mínimas comuns relativas ao apoio judiciário no âmbito desses litígios.
} 
que permitam determinar facilmente qual o tribunal competente para a resolução de um litígio, assim como o rápido e efetivo reconhecimento e execução das decisões proferidas por qualquer tribunal de um Estado Membro da União Europeia.

A este propósito, a revisão do Regulamento (CE) n. ${ }^{\circ}$ 44/2001, de 22 de dezembro de 2000, contribuiu sobremaneira para o reforço da tutela jurisdicional efetiva em matéria de competência judiciária, reconhecimento e execução de decisões. Em particular, importa destacar, entre outras medidas, a possibilidade de a ação ser proposta nos tribunais de um Estado-Membro da União Europeia em matéria de conflitos de consumo ou de conflitos laborais ainda que o réu não tenha o seu domicílio ou sede na União Europeia (arts. 6. ${ }^{\circ},{ }^{\circ}{ }^{\circ} 1,18 .^{\circ}$, n. $^{\circ} 1$, e $21 .{ }^{\circ}$, n. $^{\circ} 2$, do Regulamento) ${ }^{6}$, a alteração das regras em matéria de litispendência, que permitiu acabar com a utilização abusiva da técnica processual conhecida por "torpedo italiano" (art. 31. ${ }^{\circ}$, n. ${ }^{\circ}$ 2), e a abolição do exequatur, com o consequente reconhecimento de força executiva automática a qualquer sentença proferida pelos tribunais dos EstadosMembros da União Europeia (art. 39. ${ }^{\circ}$ ).

Todavia, as necessidades atuais de tutela jurisdicional efetiva e de proteção das relações económicas e sociais justificam, na nossa perspetiva, a revisão do Regulamento (UE) n. ${ }^{\circ}$ 1215/2012, de 12 de dezembro, em alguns aspetos que se revelam absolutamente essenciais.

\subsection{Competência em matéria contratual}

Desde logo, afigura-se essencial a revisão das regras de competência em matéria de litígios contratuais. Com efeito, muito embora o Regulamento (UE) n. ${ }^{\circ}$ 1215/2012, de 12 de dezembro, estabeleça como critério geral de competência o domicílio do réu (art. 4. $\left.{ }^{\circ},{ }^{\circ}{ }^{\circ} 1\right)$, a verdade é que a lei prevê diversos foros alternativos de competência "em razão do vínculo estreito entre a jurisdição e o litígio ou com vista a

\footnotetext{
${ }^{6}$ Assim, resulta do considerando (14) do Regulamento (UE) n. ${ }^{\circ}$ 1215/2012, de 12 de dezembro de 2012, que "a fim de assegurar a proteção de consumidores e trabalhadores, salvaguardar a competência dos tribunais dos Estados-Membros em situações em relação às quais têm competência exclusiva e respeitar a autonomia das partes, algumas normas de competência constantes do presente regulamento aplicam-se independentemente do domicílio do requerido".
} 
facilitar uma boa administração da justiça"7. Ora, um dos litígios transfronteiriços mais frequentes no atual contexto económico diz respeito às relações jurídicas contratuais, muito particularmente no âmbito da exportação de mercadorias ou de serviços. Assim, estando em causa um litígio em matéria contratual, o Regulamento (UE) n. ${ }^{\circ}$ 1215/2012, de 12 de dezembro, estabelece que a ação judicial pode ser intentada no tribunal do domicílio do réu (art. $4 .^{\circ},{ }^{\circ}{ }^{\circ} 1$ ) ou, em alternativa, no tribunal do lugar onde foi ou deva ser cumprida a obrigação em questão [art. . $^{\circ}$, n. $^{\circ} 1$, al. a)]. Contudo, o art. . $^{\circ}$, n. $^{\circ} 1$, al. b), do Regulamento estabelece que, para efeitos da presente disposição e salvo convenção em contrário, o lugar do cumprimento da obrigação em questão será, no caso da venda de bens, o lugar num Estado-Membro onde, nos termos do contrato, os bens foram ou devam ser entregues, e, no caso da prestação de serviços, o lugar num Estado-Membro onde, nos termos do contrato, os serviços foram ou devam ser prestados ${ }^{8}$.

Ora, na nossa perspetiva, este critério de competência não acautela devidamente os interesses do credor que, no âmbito de uma relação contratual internacional, pretende tão-só obter o cumprimento de uma obrigação pecuniária decorrente da venda de um bem ou da prestação de um serviço.

Com efeito, é um facto que, tal como decorre do considerando 16 do Regulamento (UE) n. ${ }^{\circ}$ 1215/2012, de 12 de dezembro, o legislador europeu teve a preocupação de "assegurar a certeza jurídica e evitar a possibilidade de o requerido ser demandado no tribunal de um Estado-Membro que não seria razoavelmente previsivel para ele".

Não obstante, não se pode ignorar que, num contexto de forte crise económica, que afeta a generalidade das economias europeias, a possibilidade de as empresas negociarem de forma livre no mercado único europeu é absolutamente essencial

\footnotetext{
${ }^{7}$ Considerando (16) do Regulamento (UE) n. ${ }^{\circ}$ 1215/2012, de 12 de dezembro de 2012.

${ }^{8}$ Conforme se decidiu no Acórdão do TJUE, de 25 de fevereiro de 2010, processo C-381/08, muito embora, em tese, o lugar da entrega do bem possa ser entendido como o lugar da entrega material do bem ao comprador ou o lugar da entrega do bem ao primeiro transportador, tendo em vista a sua posterior transmissão ao comprador, deve reconhecer-se que o lugar onde os bens foram ou devam ser materialmente entregues ao comprador, no destino final destes, corresponde melhor à génese, aos objetivos e ao sistema do regulamento, como o "lugar de entrega" na aceção do seu artigo 5. ${ }^{\circ}$, n. ${ }^{\circ}$, alínea b), primeiro travessão.
} 
para se garantir a sustentabilidade das economias, bem como o desenvolvimento e o crescimento das relações comerciais. Neste enquadramento, não se compreende que, no âmbito de uma relação jurídica plurilocalizada, em que uma empresa fornece mercadorias ou presta serviços a outra e pretende obter o pagamento correlativo, seja confrontada, na falta de convenção em sentido contrário ${ }^{9}$, com a obrigação de litigar junto dos tribunais do Estado-Membro onde os bens foram entregues ou os serviços prestados, e não dos tribunais do Estado-Membro do seu domicílio. Semelhante realidade constitui um entorpecimento ao desenvolvimento das relações comerciais no espaço europeu, porquanto, na generalidade dos casos, os agentes económicos que se deparem com a falta de pagamento de um fornecimento de bens ou de uma prestação de serviços ver-se-ão confrontados com a necessidade de proporem a ação junto dos tribunais do lugar onde os bens foram entregues ou os serviços prestados, lugar esse que, na generalidade dos casos, coincide com o domicílio do réu.

Seria, por isso desejável, face à necessidade de incremento das relações comerciais e de proteção da tutela jurisdicional efetiva, sob o prisma da facilidade de acesso aos tribunais, que o art. . $^{\circ}$ do Regulamento fosse revisto, no sentido de se estabelecer como elemento de conexão o domicílio do autor/credor quando esteja em causa um litígio em matéria contratual e este pretenda obter o cumprimento dessa obrigação.

\subsection{Competência em matéria executiva}

No domínio executivo, o Regulamento (UE) n. ${ }^{\circ}$ 1215/2012, de 12 de dezembro, procedeu à abolição do exequatur, assegurando, dessa forma, a plenitude do princípio da livre circulação das decisões.

De facto, tal como resulta do considerando (27) do Regulamento, "Para efeitos de livre circulação de decisões, uma decisão proferida num Estado-Membro deverá ser reconhecida

\footnotetext{
${ }^{9}$ Vide, a este propósito, o Acórdão do TRL, de 14 de dezembro de 2010, proc. 985/09.1TVLSB.L1-7, no qual se decidiu que "Constando do contrato que o pagamento dos créditos se realizará por meio de transferência bancária para as contas que ambas as partes comuniquem, e tendo a autora indicado para o efeito uma conta bancária domiciliada em Lisboa, encontra-se preenchido o critério especial previsto na al. a), do $n^{\circ} 1$ do art. $5^{\circ}$ do Regulamento, que remete para o tribunal do lugar onde foi ou devia ser cumprida a obrigação em questão".
} 
e executada em qualquer outro Estado-Membro, mesmo que seja tomada em relação a uma pessoa não domiciliada num Estado-Membro".

A consagração de semelhante princípio foi essencial não só para a tutela jurisdicional efetiva, como também para uma melhor integração judiciária, na medida em que o procedimento de exequatur, para além de se revelar excessivamente moroso e dispendioso, traduzia-se, na generalidade dos casos, num mero formalismo, sem que dele decorresse qualquer benefício ou garantia acrescida relativamente à decisão que se pretendia executar.

Todavia, muito embora seja inegável a importância da abolição do exequatur em matéria de integração judiciária, a verdade é que continuam a existir atualmente fortes restrições no tocante à execução de decisões, restrições essas que não se compreendem no contexto de uma Europa sem fronteiras.

$\mathrm{Na}$ verdade, em matéria executiva, continua ainda a prevalecer o princípio da territorialidade, segundo o qual cada Estado-Membro é soberano no que diz respeito à aplicação de medidas coercivas ou executivas dentro dos seus limites territoriais. Vale isto por dizer que, por força de tal princípio, correndo a ação executiva junto dos tribunais de um Estado-Membro da União Europeia, não é possível a aplicação de medidas coercivas (ex. penhora, apreensão ou entrega de bens) junto de um outro Estado-Membro.

Deste modo, ressalvada a possibilidade de o executado ser proprietário de um bem imóvel que se situe no Estado-Membro onde corre a execução, a facilidade de deslocação de bens móveis ou de direitos entre os diferentes Estados-Membros da União Europeia inviabiliza ou, no mínio, dificulta sobremaneira a possibilidade de esses bens ou direitos serem apreendidos.

Por outro lado, se o executado for proprietário de dois ou mais bens imóveis que se localizem em diferentes Estados-Membros da União Europeia, o credor ver-se-á sempre confrontado, para a eventualidade de o valor de cada um dos imóveis não ser suficiente para garantia a satisfação da dívida exequenda e das custas da execução, com a necessidade de intentar duas ou mais ações executivas, em diferentes Estados-Membros da União Europeia, em função da localização dos bens imóveis que pretenda executar. 
Ora, a questão que se coloca é a de saber se, num espaço europeu de livre circulação de decisões judiciais, faz sentido que se continue a justificar a manutenção do princípio da territorialidade, enquanto manifestação de reserva de soberania, em matéria executiva.

$\mathrm{Na}$ nossa opinião, a resposta a essa questão não pode deixar de ser negativa. $\mathrm{Na}$ verdade, não obstante a importância do reconhecimento e da força executiva automática das decisões judiciais, afigura-se que seria desejável a possibilidade de serem adotadas medidas coercivas em matéria executiva (ex. penhora, apreensão ou entrega de bens) independentemente do tribunal do lugar onde corra termos a execução.

De resto, esta solução, para além de ser perfeitamente compatível com os ideais da integração e da cooperação judiciária, tal como recebidos no art. 81. ${ }^{\circ}$ do TFUE, é igualmente a que melhor se harmoniza com a necessidade de se garantir a tutela jurisdicional efetiva no contexto europeu.

Com efeito, se é verdade que, em matéria declarativa, o legislador europeu teve a preocupação de consagrar, em alternativa ao critério geral de competência do domicílio do réu, foros especiais de competência que, "em razão do vínculo estreito entre a jurisdição e o litígio ou com vista a facilitar uma boa administração da justiça", permitem ao autor aceder aos tribunais de um Estado-Membro diferente daquele onde o réu tem o seu domicílio, a verdade é que, na fase executiva da decisão judicial que não seja voluntariamente cumprida, o autor ver-se-á inevitavelmente confrontado, na generalidade dos casos, com a necessidade de requerer a execução da sentença junto dos tribunais de um Estado-Membro diferente daquele onde a sentença foi proferida.

Assim, a título meramente exemplificativo, não faz sentido que, no contexto de um litígio em matéria contratual envolvendo uma empresa portuguesa e uma empresa francesa, em que esta última se recusa a proceder ao pagamento de uma mercadoria que lhe foi fornecida em Portugal, a ação declarativa, por via da qual a empresa portuguesa pretende obter o pagamento da quantia em dívida, possa ser proposta em Portugal, vendo-se, no entanto, a empresa portuguesa confrontada com a necessidade de propor a ação executiva junto dos tribunais franceses ou junto dos tribunais do Estado-Membro onde a empresa devedora tenha os seus bens. 
Não se ignora que a União Europeia está atenta a esta realidade e que já deu os primeiros passos no sentido de se garantir um espaço europeu de plena integração e cooperação judiciária em matéria executiva. Em concreto, assume especial destaque o Regulamento (UE) n. ${ }^{\circ}$ 655/2014, de 15 de maio de 2014, o qual criou um procedimento cautelar europeu para o arresto de contas bancárias. Com efeito, este regulamento permite que se proceda ao arresto de uma conta bancária que se encontre domiciliada num Estado-Membro diferente daquele onde corra termos o procedimento cautelar no âmbito do qual tenha sido decretado o arresto. Todavia, este regulamento não se aplica aos casos em que o credor pretenda obter o arresto de duas ou mais contas bancárias, estando uma domiciliada junto do Estado-Membro onde corre termos o procedimento cautelar de arresto e a(s) outra(s) num outro Estado-Membro - caso em que o credor terá de intentar dois procedimentos cautelares de arresto, um de âmbito nacional, e outro de âmbito europeu ${ }^{10}$ - nem tão pouco dá resposta à fase executiva da penhora da conta bancária previamente arrestada.

Deste modo, a plena integração judiciária em matéria civil e comercial, particularmente em sede executiva, reclama a derrogação do princípio da territorialidade, por forma a que, independentemente do tribunal do EstadoMembro onde corra termos a execução, seja possível a adoção de medidas coercivas, de natureza executiva, junto de qualquer outro Estado Membro da União Europeia.

\subsection{Execuçâo das decisóes}

O Regulamento (UE) n. ${ }^{\circ}$ 1215/2012, de 12 de dezembro, regula a execução das decisões dos tribunais judiciais nos seus arts. $399^{\circ}$ e ss.

Como decorrência da abolição do exequatur, o art. 39. ${ }^{\circ}$ estabelece a regra segundo

${ }^{10}$ Vide, a este respeito, o considerando (10) do Regulamento (UE) n. ${ }^{\circ}$ 655/2014, de 15 de maio de 2014, no qual se dispõe o seguinte: "O presente regulamento não deverá aplicar-se ao arresto de contas mantidas no Estado-Membro onde se encontra o tribunal em que foi apresentado o pedido de decisão de arresto se o domicílio do credor também for nesse Estado-Membro, ainda que o credor requeira ao mesmo tempo uma decisão de arresto respeitante a uma ou várias contas mantidas noutro Estado-Membro. Nesse caso, o credor deverá faz̧er dois pedidos distintos, um de decisão de arresto e outro destinado à obtenção de uma medida nacional.". 
a qual uma decisão proferida num Estado-Membro e que aí tenha força executória pode ser executada noutro Estado-Membro, sem que seja necessária qualquer declaração de executoriedade. Trata-se, com efeito, de um princípio essencial para a integração judiciária, na medida em que assegura a livre circulação das decisões no espaço europeu.

No entanto, o regime da execução de decisões previsto no Regulamento (UE) n. ${ }^{\circ}$ 1215/2012 apresenta algumas soluções que, na nossa perspetiva, devem ser revistas à luz da tutela jurisdicional efetiva.

Desde logo, dispõe o art. 42. , n. $^{\circ}$ 1, que, para efeitos da execução num EstadoMembro de uma decisão proferida noutro Estado-Membro, o requerente deve facultar às autoridades de execução competentes uma cópia da decisão que satisfaça as condições necessárias para atestar a sua autenticidade, bem como uma certidão emitida nos termos do artigo 53. ${ }^{\circ}$, que comprove que a decisão é executória e inclua um extrato da decisão, bem como, se for caso disso, informações relevantes sobre os custos processuais reembolsáveis e o cálculo dos juros.

Por sua vez, o art. 43..$^{\circ}$ n. ${ }^{\circ} 2$, do Regulamento preceitua que a pessoa contra quem seja requerida a execução pode requerer a tradução da decisão, a fim de contestar a execução, se esta não estiver traduzida numa língua que ela entenda ou na língua oficial do Estado-Membro onde está domiciliada, salvo se a pessoa já tiver sido notificada da decisão.

Muito embora a lei preveja a possibilidade de tradução da decisão, afigurase que, à luz dos princípios da segurança jurídica e da tutela jurisdicional efetiva, a decisão devia ser sempre traduzida numa língua que a pessoa compreenda, pois que só assim se pode assegurar que a pessoa contra a qual é requerida a execução da decisão compreendeu efetivamente o sentido e o alcance dessa decisão.

\section{Citação e notificação de atos judiciais e extrajudiciais}

Conforme se referiu supra, o Regulamento (CE) n. ${ }^{\circ}$ 1393/2007 do Parlamento Europeu e do Conselho, de 13 de novembro de 2007, dispõe sobre a citação e a 
notificação dos atos judiciais e extrajudiciais em matérias civil e comercial nos Estados-Membros.

O regulamento estabelece diferentes meios de citação e notificação dos atos, nomeadamente através da sua transmissão entre entidades de origem e entidades requeridas, transmissão por via diplomática e consular (arts. $12 .^{\circ}$ e $13 .^{\circ}$ ), transmissão por via postal (art. $14^{\circ}$ ) e transmissão direta com intervenção de pessoa competente (art. 15. $\left.{ }^{\circ}\right)$.

Ora, no que diz respeito à citação e notificação de atos através da sua transmissão entre entidades de origem e entidades requeridas, o art. 5. ${ }^{\circ}$ do Regulamento preceitua que o requerente deve ser avisado, pela entidade de origem competente para a transmissão, de que o destinatário pode recusar a receção do ato se este não estiver redigido numa das línguas previstas no art. 8. $^{\circ}$, ou seja, numa língua que o requerido compreenda ou na língua oficial do Estado-Membro requerido, ou, existindo várias línguas oficiais nesse Estado-Membro, na língua oficial ou numa das línguas oficiais do local onde deva ser efetuada a citação ou notificação. Nessa eventualidade, cabe ao requerente suportar as despesas de tradução que possam ter lugar previamente à transmissão do ato, sem prejuízo de eventual decisão posterior do tribunal ou autoridade competente em matéria de imputação dessas despesas.

Por sua vez, o art. $8 .^{\circ}$ do Regulamento determina que a entidade requerida deve avisar o destinatário, mediante o formulário constante do anexo II, de que pode recusar a receção do ato quer no momento da citação ou notificação, quer devolvendo o ato à entidade requerida no prazo de uma semana, se este não estiver redigido ou não for acompanhado de uma tradução numa língua que o destinatário compreenda ou na língua oficial do Estado-Membro requerido ou, existindo várias línguas oficiais nesse Estado-Membro, na língua oficial ou numa das línguas oficiais do local onde deva ser efetuada a citação ou a notificação.

Muito embora a lei preveja a possibilidade de o requerido recusar a receção do ato no momento da citação ou notificação, ou devolvendo o ato à entidade requerida no prazo de uma semana, afigura-se, mesmo assim, que este regime não tutela adequadamente o requerido, já que pode suceder que este, apesar de não 
compreender a citação ou a notificação, acabe por não recusar a receção do ato. Seria, por isso, preferível a introdução de um regime de tradução obrigatória do ato numa língua que o destinatário compreenda.

Por outro lado, o art. 14. ${ }^{\circ}$ do Regulamento (CE) n. ${ }^{\circ}$ 1393/2007 do Parlamento Europeu e do Conselho, de 13 de novembro de 2007, preceitua, quanto à citação ou notificação pelos serviços postais, que os Estados-Membros podem proceder diretamente pelos serviços postais à citação ou notificação de atos judiciais a pessoas que residam noutro Estado-Membro, por carta registada com aviso de receção ou equivalente. Com efeito, de acordo com o considerando (17) do referido regulamento, "Cada Estado-Membro deverá ter a faculdade de proceder directamente, pelos serviços postais, à citação ou notificação de actos a pessoas que residam noutro Estado-Membro por carta registada com aviso de recepção ou equivalente.".

Deste modo, não sendo feita qualquer reserva quanto a esta forma de citação, nada obsta a que o réu seja citado por via postal, ainda que essa citação seja feita em língua que o mesmo desconheça, já que a lei apenas exige que a citação ou a notificação sejam feitas através de carta registada com aviso de receção ou equivalente.

A este respeito, os tribunais portugueses têm vindo a considerar que "Se ao estrangeiro, no acto da citação, residente no estrangeiro, não for informado da possibilidade da recusa do acto, por não ir acompanhado de tradução, a citação é nula, por indiscutivelmente estarmos, face à lei portuguesa, diante de uma formalidade essencial (art. ${ }^{\circ} 198$, n. $^{\circ} 1$, do C.P.C).". Contudo, essa nulidade fica sanada se a mesma não for arguida dentro do prazo de contestação (art. 191. ${ }^{\circ}$, n. $^{\text {o }}$, do CPC) ${ }^{11}$.

Esta solução legislativa não protege minimamente o citando, já que a lei europeia não assegura adequadamente que o citando tome conhecimento efetivo do ato de citação ou de notificação, assim se acautelando a sua tutela jurisdicional efetiva.

É certo que o art. $19 .^{\circ}$ do regulamento preceitua que "Se tiver sido transmitida uma

\footnotetext{
${ }^{11}$ Vide, a este propósito, o Acórdão do TRL, de 17 de novembro de 2009, proc. 3003/08.3TVLSB-A. L1-7, com o seguinte sumário: "I - Se ao estrangeiro, no acto da citação, residente no estrangeiro, não for informado da possibilidade da recusa do acto, por não ir acompanhado de tradução, a citação é nula, por indiscutivelmente estamos, face à lei portuguesa, diante de uma formalidade essencial art. ${ }^{\circ} 198, n{ }^{\circ} 1$, do C.P.C».). II - Porém, a mesma fica sanada se não for arguida dentro do prazo do $n^{\circ} 2$, do art. ${ }^{\circ} 198$, do mesmo diploma.".
} 
petição inicial ou acto equivalente a outro Estado-Membro para citação ou notificação nos termos do presente regulamento, e se o demandado não tiver comparecido, o juiz sobrestará na decisão enquanto não for determinado: a) Que o acto foi objecto de citação ou notificação segundo a forma prescrita pela legislação do Estado-Membro requerido para a citação ou notificação de actos emitidos no seu território e dirigidos a pessoas que ai se encontrem; ou b) que o acto foi efectivamente entregue ao demandado ou na sua residência, segundo outra forma prevista pelo presente regulamento; e que, em qualquer destes casos, quer a citação ou notificação, quer a entrega, foi feita em tempo útil para que o demandado pudesse defender-se".

Se é um facto que a obrigatoriedade de realização da citação ou da notificação em conformidade com a legislação prescrita pelo Estado Português obriga que essa comunicação seja feita em língua portuguesa (arts. $133 .^{\circ}$ e $134{ }^{\circ}$ ), a verdade é que o regulamento permite que o juiz considere que a citação foi efetivamente realizada quando o ato tenha sido entregue ao demandado ou na sua residência.

Seria, por isso, desejável que o art. 14. ${ }^{\circ}$ do Regulamento previsse, quanto à citação ou notificação por via postal, a obrigatoriedade de o ato ser comunicado em língua que o destinatário compreenda ou em língua do Estado-Membro onde o requerido se encontre domiciliado.

\section{Conclusão}

A tutela jurisdicional efetiva europeia depende, essencialmente, da plena cooperação judiciária entre os diferentes Estados-Membros. Com efeito, apesar de, nos últimos anos, se ter assistido a um crescente esforço no sentido de se garantir a proteção da tutela jurisdicional efetiva, particularmente no domínio da competência judiciária, reconhecimento e execução de decisões, obtenção de provas, citação e notificação de atos judiciais e extrajudiciais e assistência judiciária, afigura-se necessário proceder a algumas correções legislativas, no sentido de se promover o reforço da integração judiciária europeia.

Assim, no que concerne à competência judiciária e ao reconhecimento e execução de decisões em matéria civil e comercial, continuam a verificar-se fortes restrições, 
particularmente no domínio da execução de decisões, que não são compatíveis com a ideia de uma Europa sem fronteiras. Na verdade, a possibilidade de livre execução das decisões no espaço europeu impõe, necessariamente, a abolição do princípio da territorialidade ou da soberania dos Estados em matéria executiva. Ademais, a segurança jurídica, inerente à tutela judicial efetiva, reclama a obrigatoriedade de tradução da decisão condenatória em língua que o réu conheça ou em língua oficial do Estado-Membro onde este se encontre domiciliado, só assim se garantindo que o réu compreendeu adequadamente o sentido e o alcance do ato judicial que poderá vir a ser objeto de execução.

Por outro lado, no que concerne à citação e notificação de atos judiciais e extrajudiciais no espaço europeu, afigura-se essencial a introdução de alterações legislativas que permitam proteger adequadamente o citando. Em particular, entendemos que a possibilidade de o ato ser transmitido diretamente por via postal, sem qualquer reserva quanto à língua empregue, não acautela devidamente a segurança jurídica, razão pela qual dever proceder-se a uma revisão legislativa, no sentido de se impor a obrigatoriedade de o ato ser comunicado em língua que o citando compreenda ou, no mínimo, em língua oficial do Estado-Membro do seu domicílio.

Em conclusão, as alterações legislativas ora propostas afiguram-se absolutamente essenciais para o reforço da integração judiciária e para a efetividade da tutela jurisdicional, enquanto pilares fundamentais do projeto europeu. 


\title{
Crise migratória na União Europeia: as principais medidas adotadas e a defesa dos direitos humanos
}

\author{
Maria Teresa Alves* \\ RESUMO: Neste artigo, temos como propósito mapear, sucintamente, as principais medidas adotadas pela União \\ Europeia para responder às necessidades prementes da crise migratória, e perceber que implicacõoes têm no âmbito dos \\ direitos humanos. \\ PALAVRAS-CHAVE: União Europeia - crise migratória - direitos bumanos - zonas dos pontos de crise - \\ recolocação - Declaração UE-Turquia - princípio de non-refoulement. \\ ABSTRACT: This paper aims to map the main measures adopted by the European Union to respond to the pressing \\ needs of the migratory crisis, and to realize the implications they have for human rights. \\ KEYWORDS: European Union - migratory crisis - buman rights - botspot areas - relocation - EU-Turkey Summit \\ - principle of non-refoulement.
}

\footnotetext{
* Mestranda em Direitos Humanos na Universidade do Minho.
} 


\section{Introdução}

Crise tem sido um dos termos adotados para descrever a chegada de migrantes e de requerentes de asilo à Europa, nos últimos anos. Neste caso particular, já qualificado como a maior crise humanitária alguma vez enfrentada pela União Europeia e uma das maiores desde o final da Segunda Guerra Mundial, não poderá ser imputada à chegada de um fluxo massivo de migrantes e de requerentes de proteção internacional. Pelo contrário, deverá ser reflexo da forma como a União Europeia tem procedido neste contexto. Por outras palavras, esta crise tornou-se, antes de mais, a crise de uma política comum da União em matéria de asilo, de proteção subsidiária e de proteção temporária, cuja configuração evidenciou sempre aspetos controversos. É também uma crise de solidariedade, uma vez que os Estados-Membros demonstram ser incapazes de encontrar uma abordagem comum e de cooperarem com os EstadosMembros mais procurados pelos migrantes e requerentes de proteção internacional.

Perante o exposto, neste artigo, pretendemos mapear, sucintamente, as principais medidas adotadas pela União Europeia para responder às necessidades prementes da crise humanitária, e perceber que implicações têm no âmbito dos direitos humanos.

\section{Migrantes económicos e refugiados}

Para um melhor esclarecimento desta exposição, consideramos fundamental traçar uma distinção conceptual entre migrantes económicos e refugiados. Porque o primeiro grupo de pessoas "procura melhores condições de vida, do ponto de vista socioeconómico" mas "não existe qualquer proteção legal prevista a nível internacional, o que permite uma maior margem de manobra aos países de destino no que diz respeito à gestão de fluxos migratórios desta natureza"2. Ao contrário, os refugiados, que representam a maioria das pessoas que procuram chegar à União Europeia, fogem à guerra e/ou à

\footnotetext{
${ }^{1}$ Daniela Nascimento e Maria Raquel Freire. "Desafiar a agenda? Políticas e práticas de in(ex)clusão na UE: um olhar sobre os fluxos de refugiados”, Debater a Europa 16 (outubro-2016): 136.

${ }^{2}$ Nascimento e Freire. "Desafiar a agenda? Políticas e práticas." 136.
} 
perseguição no seu país de origem e nacionalidade, existindo uma base de proteção legal e obrigatória, definida internacionalmente e concretizada na Convenção de Genebra de 1951 e no Protocolo de Nova Iorque de 1967. Nestes instrumentos de direito internacional, encontramos definido o estatuto de refugiado e os critérios de proteção que este estatuto garante, estabelecendo "uma 'proteção contratual' a uma escala sem precedentes", com o compromisso dos Estados-parte e "cuja matriz de proteção dos refugiados é, assumidamente, centrada nos direitos humanos e/ ou no bumanitarismo"4.

\section{As principais medidas adotadas e os direitos humanos em questão}

"São três as principais medidas tomadas no plano da União Europeia para fazer face à crise em epígrafe, que se tornou realmente sem precedentes a partir do Verão de 2015"5. Abordaremos, em primeiro lugar, a criação de zonas dos pontos de crise, que consta do Regulamento 2016/1624 de 14 de setembro, relativo à Guarda Europeia de Fronteiras e Costeira. $\mathrm{E}$ nos termos do art. 2. ${ }^{\circ}$, ponto 10 , encontram-se definidas como zonas em que " 0 Estado-membro de acolhimento, a Comissão, as agências da União competentes e os Estados-membros participantes cooperam, com o objectivo de gerir um desafio migratório existente ou potencialmente desproporcionado, caracterizado por um aumento significativo do número de migrantes que chegam às fronteiras externas". Tal cooperação concretiza-se através de "equipas de apoio à gestão dos fluxos migratórios", definidas pelo ponto 9 do mesmo art., como as equipas de peritos que fornecem reforço técnico e operacional, cujo regime jurídico se encontra no art. 18. ${ }^{\circ}$

Acontece que, "a sua instalação e colocação em funcionamento têm sido lentas, tendo em conta tudo o que exigem em termos de conjugação de esforços e de coordenação, assim como de aprovação de legislação adequada". ${ }^{6}$ O primado que o Regulamento 2016/1624 atribui à

\footnotetext{
${ }^{3}$ Atle Grahl-Madsen. "The European Tradition of Asylum and the Development of Refugee Law", Journal of Peace Research 1 (setembro-1996), 278.

${ }^{4}$ Patricia Tuitt. "Human rights and refugees", The International Journal of Human Rights(1997): 66-67.

${ }^{5}$ Piçarra Nuno. "A União Europeia e «a crise migratória e de refugiados sem precedentes»: crónica breve de uma ruptura do Sistema Europen Comum de Asilo, e-Pública. 2 (novembro-2016): 30.

${ }^{6}$ Piçarra. "A União Europeia e «a crise migratória", 34.
} 
Agência Europeia de Guardas de Fronteiras e Costeira, nas zonas dos pontos de crise, revela uma abordagem mais securitária do Sistema Europeu Comum de Asilo na gestão dos fluxos mistos, e, por conseguinte, menos centrada nas reais necessidades de proteção internacional que suscitam e às quais os Estados-Membros da União se encontram vinculados. Por outro lado, estas zonas dos pontos de crise e as atividades que aí se desenvolvem limitam-se a ajudar os Estados-Membros de primeira entrada na execução da tarefa desproporcionada que lhes impõem os Regulamentos Dublin III e Eurodac de recolher as impressões digitais de todas as pessoas que atravessaram irregularmente as respetivas fronteiras. O que determina "a responsabilidade desses Estados pela análise dos correspondentes pedidos de asilo, tornando efectivos os desequilíbrios

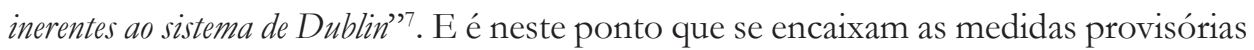
adotadas a favor da Itália e da Grécia, que analisamos no parágrafo seguinte.

A Decisão 2015/1523 do Conselho, de 14 de setembro, e a Decisão 2015/1601, também do Conselho, de 22 de setembro, adotadas com base no art. $78 .^{\circ}$, n. ${ }^{\circ}$ 3, do Tratado sobre o Funcionamento da União Europeia, que estipula a possibilidade de adoção de medidas provisórias, por parte do Conselho, sob proposta da Comissão, a favor de um ou mais Estados-Membros, confrontados com uma situação de emergência, determinam as medidas provisórias no domínio da proteção internacional a favor da Itália e da Grécia, a fim de ajudar estes países a enfrentarem melhor o súbito e desproporcionado afluxo de nacionais de países terceiros nos seus territórios. Ambas as decisões estabelecem um mecanismo de recolocação somente aplicável aos nacionais de países terceiros que i) tenham apresentado um pedido de proteção internacional em Itália ou na Grécia, pela análise do qual esses Estados seriam responsáveis, segundo os critérios estabelecidos no capítulo III do Regulamento Dublin III e ii) tenham nacionalidades relativamente às quais a percentagem de decisões de concessão de proteção internacional adotadas em primeira instância seja igual ou superior a 75\% do total dessas decisões. Nos termos do art. $4 .^{\circ}$, n. ${ }^{\circ}$ 5, da segunda decisão, qualquer Estado-Membro poderia, em circunstâncias excecionais, notificar o Conselho e a Comissão, até 26 de dezembro de 2015, de que se encontrava

${ }^{7}$ Piçarra. "A União Europeia e «a crise migratória", 34. 
temporariamente impedido de participar na recolocação de, no máximo, 30\% dos requerentes atribuídos, apresentando razões devidamente justificadas e compatíveis com os valores fundamentais da União, consagrados no artigo 2. ${ }^{\circ}$ do Tratado sobre o Funcionamento da União Europeia.

A primeira decisão estabelece a recolocação, voluntária, entre os EstadosMembros de recolocação, de 40.000 pessoas com clara necessidade de proteção internacional, 24.000 a partir da Itália e 16.000 a partir da Grécia (art. 4. ${ }^{\circ}$ ). A segunda decisão, em contrapartida, determina obrigatoriamente a recolocação de 120.000 pessoas carecidas de proteção nos outros Estados-Membros, de acordo com os quadros de contingentes estabelecidos em anexo (art. 4. ${ }^{\circ}$ ).

No preâmbulo das decisões em análise (respectivamente, $18 .^{\circ}$ e $23 .^{\circ}$ considerandos) reconhece-se, não apenas uma derrogação ao Regulamento Dublin III, como uma derrogação ao consentimento do requerente de proteção internacional, exigido pelo art. 7. $^{\circ}$, n. ${ }^{\circ}$ 2, do Regulamento n. ${ }^{\circ}$ 516/201464 que cria o Fundo para o Asilo, a Migração e a Integração. Atentemos, "essas operações são realizadas com o consentimento das pessoas em causa e consistem na transferência de um Estado-membro que lhes concedeu proteção internacional ou é responsável pela análise do seu pedido de asilo, para outro Estado-membro interessado, onde beneficiarão de proteção equivalente ou se procederá à análise dos seus pedidos de proteção internacional' (art. 7. ${ }^{\circ}$, n..$^{\circ} 2$ do Regulamento referido supra).

$\mathrm{Na}$ nossa opinião, estas Decisões do Conselho são o lado mais visível da "grave desunião europeia que se verifica no âmbito da politica comum de asilo e do Sistema Europeu Comum de Asilo"8. A segunda decisão teve os votos contra da Hungria, da República Checa, da Eslováquia e da Roménia e as abstenções da Polónia e da Finlândia. E os quatro Estados-Membros do grupo de Visegrád recusaram-se a dar cumprimento à decisão de recolocação. Na Hungria, a quota de refugiados atribuída pela Decisão 2015/1601 foi, inclusive, submetida a referendo, realizado no dia 2 de outubro de 2016, e rejeitada (apesar de não ser uma rejeição juridicamente vinculativa segundo o direito nacional húngaro). Por outro lado, a recolocação de pessoas nos EstadosMembros que não se opuseram ao cumprimento das decisões do Conselho "tem

\footnotetext{
${ }^{8}$ Piçarra. "A União Europeia e «a crise migratória", 36.
} 
experienciado obstáculos e lentidões burocráticas sérias, continuando o número de recolocações muito baixo (ultrapassando em pouco os seis mil)"'. Refletindo a falta de vontade da generalidade dos Estados-Membros na execução das decisões adotadas.

Finalmente, a Declaração UE-Turquia de 7 de março de 2016 surge como uma nova tentativa de alcançar solução para a crise no plano da União Europeia. Mediante tal declaração, a União Europeia, por um lado, e a Turquia, por outro, acordaram o seguinte: i) todos os novos migrantes em situação irregular que partam da Turquia e cheguem às ilhas gregas a partir de 20 de março de 2016 são devolvidos à Turquia; os custos das operações de retorno desses migrantes ficam a cargo da União Europeia; ii) por cada sírio devolvido à Turquia a partir das ilhas gregas, outro sírio deslocado na Turquia é reinstalado na União Europeia, devendo criar-se um mecanismo para o efeito, com o apoio da Comissão, das agências da União e de outros Estados-Membros; iii) a Turquia toma todas as medidas necessárias para evitar a abertura, a partir do seu território, de novas rotas de migração irregular, marítimas ou terrestres, em direção à União Europeia; iv) e esta, por seu lado, agiliza o pagamento à Turquia do montante de três biliões de euros para apoio aos refugiados instalados em território turco.

Este acordo foi alvo de várias críticas, entre as quais destacamos: i) a incompatibilidade com os art.: $70{ }^{\circ}$ do Tratado sobre o Funcionamento da União Europeia, $1 .^{\circ}, 18 .^{\circ}$ e $19 .^{\circ}$ da Carta dos Direitos Fundamentais da União Europeia e art. 4. ${ }^{\circ}$ do Protocolo n. ${ }^{\circ} 4$ à Convenção Europeia dos Direitos Humanos, que consagram as proibições de expulsão colectiva e de repulsão de acordo com o princípio de nonrefoulement; tendo em conta a cláusula da declaração que estipula que todos os novos migrantes irregulares que viagem da Turquia para a Grécia a partir de 20 de março de 2016 deverão ser devolvidos à Turquia; ii) a Turquia não é um país terceiro seguro na aceção do art. 38. ${ }^{\circ}$ da Diretiva 2013/32, na medida em que, devido a uma reserva feita no momento da assinatura da Convenção de Genebra, não está vinculada a aplicá-la em relação com os acontecimentos ocorridos fora da Europa. Ou seja, a Turquia apenas aplica plenamente a Convenção de Genebra às pessoas que fogem à perseguição e/ou à guerra, na Europa.

${ }^{9}$ Piçarra. "A União Europeia e «a crise migratória", 36. 
As críticas mais fortes contra um acordo UE-Turquia vieram de "organizações de direitos humanos preocupadas com as potenciais consequências bumanitárias e com a legalidade de um regresso directo de migrantes e/ ou refugiados da Grécia para a Turquia" ${ }^{10}$. Argumentando que a União Europeia e os seus membros têm a obrigação legal e moral de proteger as pessoas carecidas de proteção internacional que chegam às margens da Europa.

Apesar de todas as críticas, a declaração em análise, tem a possibilidade de, por um lado, impedir rotas irregulares de migração para a Europa e, por outro lado, de "viabilizar a reinstalação enquanto canal legal de acesso à União Europeia para as pessoas carecidas de proteção internacional"11. No entanto, o "imperativo bumanitário" exige que o acordo UE-Turquia seja complementado por uma política comum de asilo muito mais eficiente e por outras medidas a longo prazo", ${ }^{12}$ no âmbito de um plano global destinado a equilibrar solidariedade e segurança.

\section{Conclusão}

Até agora, "a União Europeia, e os seus Estados-Membros, dão prioridade à gestão das fronteiras externas e lutam contra a migração irregular, em detrimento de um regime de asilo e de migração legal adequado"'13. Consequentemente, a securitização do migrante como ameaça apenas contribui para distorcer os compromissos dos Estados-Membros em matéria de proteção internacional. O tratamento da questão, de forma eficiente, deveria, ao invés, contribuir para reforçar os direitos fundamentais tal como, a estabilidade interna e nas fronteiras da União.

Todas as medidas adotadas são de caráter conjuntural e de eficácia diminuta.

\footnotetext{
10 "Elements of a complex but still incomplete puzzle: as assessment of the EU (-Turkey) summit", Janis A. Emmanoulidis, acesso em setembro 7, 2016, http://www.epc.eu/pub_details.php?cat_id=5\&pub_ $\mathrm{id}=6417 \&$ year $=2016$

11 Piçarra. "A União Europeia e a crise migratória", 38.

12 "Elements of a complex but still incomplete puzzle: as assessment of the EU (-Turkey) summit", Janis A. Emmanoulidis.

13 "Migrants and Refugees have rights! Impact of UE policies on accessing protection", Patrick Taran, acesso em outubro 1, 2016, http://www.caritas.eu/sites/default/files/160317_migration_report_ migrants_have_rights.pdf.
} 
Tratando a gestão migratória de forma reativa e demorada. Além de que são acompanhadas por medidas unilaterais dos Estados-Membros de trânsito e de destino do afluxo de migrantes e de refugiados que, vão desde a reintrodução de controlos nas fronteiras internas, construção de muros nas fronteiras externas, às comunicações de limitações ou de recusas ao acolhimento de requerentes de proteção internacional.

Deste modo, por um lado, nunca foram tão evidentes as insuficiências das medidas adotadas para solucionar o afluxo massivo de migrantes na Europa, e, por outro lado, as condições políticas nunca foram tão adversas para reformar de forma eficaz, coesa e de acordo com os sistemas de proteção dos direitos humanos em geral e dos refugiados em particular, legalmente previstos, a política europeia comum em matéria de asilo, proteção subsidiária e proteção temporária, bem como o sistema de Dublin III. 


\title{
Corte Interamericana de Direitos Humanos e Jurisdição Constitucional: Interconstitucionalidade e diálogo entre Cortes na perspetiva do Supremo Tribunal Federal ${ }^{*}$
}

\author{
Mônia Clarissa Hennig Leal ${ }^{* *}$
}

RESUMO: A conformação de uma ordem jurídica internacional de proteção aos direitos humanos à qual estão submetidos os Estados traz o desafio de existência de uma pluralidade normativa, caracterizada pela existência de um direito originado de múltiplas fontes. No Brasil, este fenômeno se apresenta em razão da vinculação ao Sistema Interamericano $e$ ao reconbecimento da jurisdição da Corte Interamericana de Direitos Humanos, contexto em que a existência de um diálogo interjurisdicional se afigura como uma importante ferrramenta para a consecução desse fim. Assim, o problema que se pretende enfrentar no presente trabalho consiste em analisar este diálogo interjurisdicional e suas características.

PALAV RAS-CHAVE: interconstitucionalidade - diálogo entre Cortes - Corte Interamericana de Direitos Humanos.

ABSTR ACT: The development of an international system of human rights protection brings with it the challenge of concealing rights that provide from different and phural sources. In Brazil, this phenomenon arises from the the Interamerican System of Human Rights Protection and the recognition to the Interamerican Court of Human Rights jurisdiction, context in which the conformation of a dialog between Courts arises as important tool. So, the main purpose of this article is to anabyse this kind of dialog and its characteristics.

KEYWORDS: interconstitutionality - dialog between Courts - Interamerican Court of Human Rights.

\footnotetext{
* Este artigo é resultante das atividades do projeto de pesquisa 'Dever de proteção (Schutzpflicht) e proibição de proteção insuficiente (Untermassverbot) como critérios para o controle jurisdicional (qualitativo) de Políticas Públicas: possibilidades teóricas e análise crítica de sua utilização pelo Supremo Tribunal Federal e pela Corte Interamericana de Direitos Humanos", financiado pelo CNPq (Edital Universal - Edital 14/2014 - Processo 454740/2014-0) e pela FAPERGS (Programa Pesquisador Gaúcho - Edital 02/2014-Processo 2351-2551/14-5). A pesquisa é vinculada ao Grupo de Pesquisa "Jurisdição Constitucional aberta” (CNPq) e desenvolvida junto ao Centro Integrado de Estudos e Pesquisas em Políticas Públicas - CIEPPP (financiado pelo FINEP) e ao Observatório da Jurisdição Constitucional Latino-Americana (financiado pelo FINEP e pela Capes - Edital PGCI 02/2015), ligados ao Programa de PósGraduação em Direito - Mestrado e Doutorado da Universidade de Santa Cruz do Sul - UNISC. Também se insere no âmbito do projeto de cooperação internacional "Observatório da Jurisdição Constitucional Latino-Americana: recepção da jurisprudência da Corte Interamericana de Direitos Humanos e sua utilização como parâmetro para o controle jurisdicional de Políticas Públicas pelos Tribunais Constitucionais", financiado pela Capes (Edital PGCI 02/2015 - Processo 88881.1375114/2017-1 e Processo 88887.137513/2017-00).

** Coordenadora adjunta do Programa de Pós-Graduação em Direito da Universidade de Santa Cruz do Sul - UNISC. Doutora em Direito pela Universidade do Vale do Rio dos Sinos - UNISINOS, com estágio pós-doutoral na Ruprecht-Karls Universität Heidelberg, Alemanha.
} 


\section{Introdução}

A conformação de uma ordem jurídica internacional de proteção aos direitos humanos à qual estão submetidos os Estados (ainda que por meio de uma adesão voluntária) acaba por trazer o desafio de existência de uma pluralidade normativa, caracterizada pela existência de um direito originado de múltiplas fontes. No Brasil, este fenômeno se apresenta em razão da vinculação ao Sistema Interamericano e ao reconhecimento da jurisdição da Corte Interamericana de Direitos Humanos, demandando uma atividade interpretativa capaz de harmonizar a ordem jurídica interna e a ordem jurídica externa, no sentido da máxima proteção desses direitos, situação em que a existência de um diálogo interjurisdicional se afigura como uma importante ferrramenta para a consecução desse fim. Nesse contexto, o problema que se pretende enfrentar no trabalho consiste em analisar, este diálogo interjurisdicional e suas características.

\section{Diálogo jurisdicional vertical como instrumento de harmonização entre a ordem jurídica interna externa}

O diálogo interjurisdicional apresenta-se como uma das facetas da internacionalização dos direitos humanos, fenômeno histórico que vem se intensificando desde meados do século passado, consubstanciando-se em "un diálogo judicial que se desarrolla en un espacio en que las fronteras nacionales, culturales, lingüisticas retroceden cada día un poco más, ante sistemas jurídicos internacionales y supranacionales" 1 .

Assim, pode-se dizer que o Direito contemporâneo está passando “de formes de pouvoir autoritaires, hiérarchiques, verticales à des formes négociées, réticulaires, horizontales, consensuelles, plus civilisées, mais plus complexes"2. O diálogo interjurisdicional representa uma das características desse novo paradigma do Direito, que deixa de lado o state

\footnotetext{
${ }^{1}$ Humberto Nogueira Alcalá, "Diálogo interjurisdiccional, control de convencionalidad y jurisprudencia del Tribunal Constitucional en período 2006-2011”, Revista Estudios Constitucionales 10,2 (2012): 58.

${ }^{2}$ Ignacio Ramonet, Géopolitique du chaos (Paris: Gallimar, 2001), 7-8.
} 
approach, muito apegado à ideia de soberania nacional, para assumir o modelo do buman rights approach, centrado na primazia dos direitos humanos ${ }^{3}$. Dessa mudança paradigmática resulta, por sua vez: "el diálogo jurisprudencial entre la justicia local y la internacional, siempre teniendo en cuenta que los Estados al plegarse al Pacto de San José han consentido en limitar su soberania en beneficio de un bien superior al mismo que - como dice Nogueira Alcalá -, es el respeto a la dignidad inherente al ser bumano. Ello implica en definitiva reconocer que la soberanía Estatal está restringida en su ejercicio por el respeto y garantía efectiva de los derechos bumanos"'.

Segundo Piovesan", essa transformação positiva revela-se na "crescente abertura do Direito - agora 'impuro' -, marcado pelo diálogo do ângulo interno com o ângulo externo’. Para a autora, essa transformação é representada, inter alia, pela "permeabilidade do Direito mediante o diálogo entre jurisdições", o qual figura como "el novo referente jurisdicional para la efectividad de los derechos humanos em el Siglo XXT'. ${ }^{6}$

Com efeito, a ideia de diálogo interjurisdicional pressupõe uma sinergia entre os diversos juízes e tribunais, em busca da evolução do Direito, retirando, a priori, a relação de autoridade ou de hierarquia entre os órgãos judiciais, os quais, diante desse novo paradigma, visam, em conjunto, a alcançar soluções para os diferentes desafios jurídicos, notadamente na seara dos direitos humanos: “l'expression 'dialogue des juges' renvoie à l'idée de discussion, de concertation, et a le mérite de fournir un concept consensuel [...] écartant a priori toute relation d'autoritê"

No mesmo sentido é o escólio de Alcalá ${ }^{8}$, para quem o diálogo interjurisdicional

\footnotetext{
${ }^{3}$ Flávia Piovesan, "Direitos humanos e diálogo entre jurisdições”, Revista Brasileira de Direito Constitucional - RBDC 19 (jan./jun 2012).

${ }^{4}$ Juan Carlos Hitters, "Control de Convencionalidad (Adelantos y retrocesos)", Revista Estudios Constitucionales 13,1 (2015): 139.

${ }^{5}$ Flávia Piovesan, "Direitos humanos”, 70.

"Eduardo Ferrer Mac-Gregor, "La obligación de "respetar" y "garantizar" los derechos humanos a la luz de la jurisprudencia de la Corte Interamericana”, Revista Estudios Constitucionales, 10,2 (2012): 149.

${ }^{7}$ Frédéric Sudre, "Avant-propos", in Le dialogue des juges (Montpellier: Institut de Droit des Droits del L'Homme. Cahiers de L'IDEDH n. $\left.{ }^{\circ} 11,2007\right), 8$.

${ }^{8}$ Humberto Nogueira Alcalá, "Diálogo interjurisdiccional y control de convencionalidad entre los tribunales nacionales y la Corte Interamericana de Derechos Humanos en Chile", Anuario de Derecho Constitucional Latinoamericano XIX (2013): 531.
} 
propende a "construir soluciones mediante un esfuerzo común, dialogado, de fortalecimento de los derechos fundamentales". E, nesse diálogo, não são só os tribunais nacionais que tendem a evoluir em sua atuação na tutela dos direitos humanos, mas também os tribunais regionais e internacionais". Nesse passo é que se pode dizer que "el 'diálogo jurisprudencial se convierte en una herramienta de 'doble vía' de interacción" ${ }^{10}$ que beneficia ambos os dialogantes.

A própria Corte IDH reconhece a relevância desse diálogo, afirmando que ele possui dois efeitos concretos: de um lado, permite que os tribunais domésticos aumentem o grau de proteção dos direitos humanos no plano nacional ao adotar os standards mínimos definidos pela Corte IDH; de outro, a jurisprudência produzida no nível local auxilia no desenvolvimento de sua própria jurisprudência, enriquecendo-a e fortalecendo, assim, a vigência dos direitos humanos e fundamentais ${ }^{11}$.

Sem embargo, insta mencionar que o referido diálogo não se realiza apenas entre tribunais nacionais e tribunais internacionais. Trata-se, isto sim, de uma conversação que envolve todos os âmbitos da jurisdição interna e internacional, nas mais diversas combinações dialogais: "constituye un debate, una conversación o intercambio de puntos de vista entre dos o más jueces o tribunales, sean estos nacionales, o producto de una vinculación del Estado a un ordenamiento juridico y tribunal internacional o supranacional, un diálogo entre tribunales nacionales, como ocurre entre tribunales ordinarios y tribunal constitucional; entre tribunales nacionales e internacionales o supranacionales, como es el caso entre jueces y tribunales nacionales ordinarios o constitucionales con la Corte Interamericana de Derechos Humanos [... ] o en Europa con el Tribunal Europeo de Derechos Humanos [...]; como asimismo, puede darse como un diálogo entre tribunales internacionales o supranacionales, por ejemplo entre cortes regionales de derechos bumanos" ${ }^{\prime 2}$.

\footnotetext{
${ }^{9}$ Humberto Nogueira Alcalá, "Diálogo interjurisdiccional y control de convencionalidad”, 531-532.

${ }^{10}$ Eduardo Ferrer Mac-Gregor, “La obligación”, 154.

${ }^{11}$ De acordo com o seu mais recente relatório anual, "o diálogo judicial é de vital importância e continuará sendo um dos principais aspectos nos quais a Corte Interamericana deve continuar trabalhando". O relatório ainda refere que "a Corte Interamericana assumiu o diálogo como um dos principais caminhos para cumprir seu trabalho de defender e promover os direitos humanos de todas as pessoas das Américas". "Relatório Anual 2015", Corte Interamericana de Direitos Humanos (Corte IDH), acesso em setembro 15, 2017, http://www.corteidh.or.cr/index. $\mathrm{php} / \mathrm{en} /$ court-today/informes- anuales.

${ }^{12}$ Humberto Nogueira Alcalá, "Diálogo interjurisdiccional, control de convencionalidad y jurisprudencia”, 58.
} 
Quando o diálogo ocorre entre tribunais ou juízes cujas decisões não são vinculantes de um para o outro, tem-se um diálogo interjurisdicional horizontal. É o que ocorre, por exemplo, no fecundo diálogo entre a Corte IDH e a Corte Europeia de Direitos Humanos, responsável pela evolução de ambas as jurisdições. Em casos tais, o diálogo ocorre de modo aberto e espontâneo, livre de qualquer vinculação jurídica, sem necessariamente haver uma relação jurídica entre as cortes ou juízes dialogantes ${ }^{13}$.

Diferentemente, o diálogo vertical ocorre quando um dos tribunais ou juízes presentes no diálogo está vinculado às decisões proferidas pelo outro. É o que ocorre com a jurisprudência do Supremo Tribunal Federal, com relação aos demais órgãos judiciais que compõem a estrutura do Poder Judiciário nacional, sendo o que ocorre, também, na relação entre a Corte IDH e os tribunais nacionais dos países que, assim como o Brasil, tenham reconhecido a obrigatoriedade de sua jurisdição. Desse modo, o diálogo é vertical, uma vez que é levado a cabo "entre un juez interno y un juez. internacional, siendo este último el cual tiene la última palabra en las materias en que el Estado parte se ha sometido a su jurisdicción vinculante, en el ámbito de su competência" ${ }^{14}$.

É possível, ainda, neste contexto, falar-se de um diálogo vertical ascendente (quando ele se inicia no âmbito do órgão jurisdicional vinculado) e de um diálogo vertical descendente (quando é provocado pelo órgão judicial que detém a última palavra, em direção aos juízes e tribunais que a ele se vinculam) ${ }^{15}$.

Nesse aspeto, é possível diferenciarem-se cinco modalidades de interpretação/ diálogo: a) interpretação inovadora; b) interpretação extensiva; c) interpretação recetiva; d) interpretação corretiva; e) interpretação neutralizadora.

A interpretação inovadora ocorre quando o Judiciário nacional realiza interpretação de dispositivo convencional do corpus iuris sobre o qual a Corte IDH ainda não se manifestou. Nessa situação, o juiz doméstico cria uma solução

\footnotetext{
${ }^{13}$ Humberto Nogueira Alcalá, "Diálogo interjurisdiccional, control de convencionalidad y jurisprudência”, 59.

${ }^{14}$ Humberto Nogueira Alcalá, "Diálogo interjurisdiccional, control de convencionalidad y jurisprudência”, 58.

15 Para os fins do presente trabalho, interessa, especialmente, o diálogo interjurisdicional vertical ascendente realizado pelo Supremo Tribunal Federal com a Corte IDH. Cf. Humberto Nogueira Alcalá, "Diálogo interjurisdiccional y control de convencionalidad", 511-553.
} 
jurisprudencial inédita, pela invocação direta de norma do corpus iuris regional, e, desse modo, "abre la vía al diálogo com el juez de la CIDH, a través de un diálogo ascendente, el cual queda suspendido hasta que la CIDH conociendo de un caso análogo confirme o revierta la decisión adoptada por el juez nacional' ${ }^{\prime 16}$. Neste caso, entende-se que o juiz nacional dispõe de uma considerável margem de apreciação, visto que a Corte regional ainda não se manifestou sobre a matéria sub judice ${ }^{17}$.

Veja-se que, diante do princípio da inafastabilidade da jurisdição, essa modalidade de interpretação afigura-se incontornável, visto que o Judiciário não pode se abster de decidir o caso sob a alegação de que a norma convencional carece de interpretação pela Corte regional. De resto, é de se sinalar, também, que, no sistema interamericano, ela encontra guarida no princípio da subsidiariedade da jurisdição regional, pelo qual é o juiz nacional quem primeiro deve aplicar e interpretar o direito convencional nos casos levados a juízo ${ }^{18}$.

Já a interpretação extensiva ocorre quando o tribunal nacional desenvolve uma interpretação que ultrapassa, no que concerne ao grau de tutela dos direitos humanos, os contornos da definição até então desenvolvida pela Corte IDH em relação a determinado dispositivo do corpus iuris regional. Ela se distingue, por sua vez, da interpretação inovadora, pois, ao contrário daquela, há um pronunciamento e uma interpretação da Corte IDH, que é, todavia, ampliada pela jurisdição nacional: "a lieu à l'occasion d'une application de la Convention qui n'est pas inconnue de la Court de Strasbourg, le juge national confere une portée plus grande à um droit' ${ }^{19}$. Ela favorece, portanto, a ampliação do âmbito de proteção dos direitos humanos e fundamentais: "une interprétation de la Convention qui favorise un élargissement du champ d'application du droit garanti et, en conséquence, la soumission au respect de ce droit de situations qui ne sont pas visées par la jurisprudence européenne"20.

\footnotetext{
${ }^{16}$ Humberto Nogueira Alcalá, "Diálogo interjurisdiccional y control de convencionalidad”, 511-553.

${ }^{17}$ Hervé Suxe, La dimension objective du "dialogue des juges", in Le dialogue des juges (Montpellier: Institut de Droit des Droits del L'Homme. Cahiers de L'IDEDH N 11, 2007), 173-174.

${ }^{18}$ Humberto Nogueira Alcalá, "Diálogo interjurisdiccional, control de convencionalidad y jurisprudencia”, 79.

${ }^{19}$ Colombine Madelaine, "L'anticipation Manifestation d'un dialogue "vrai" entre juge national et juge européen?”, in Le dialogue des juges (Montpellier: Institut de Droit des Droits del L'Homme. Cahiers de L'IDEDH n. $\left.{ }^{\circ} 11,2007\right), 133$.

${ }^{20}$ Frédéric Sudre, "A propos du "dialogue des juges" et du control de conventionalité", in Etudes en
} 
Trata-se, por conseguinte, de uma modalidade de diálogo entre jurisdições que, ante o princípio "favor persona", é encorajada pelo direito internacional dos direitos humanos. Mediante uma interpretação extensiva, que alarga o grau de proteção de um direito humano previsto no corpus iuris interamericano, o Judiciário nacional está potencialmente a dialogar com a Corte IDH, a qual poderá adotar o entendimento doméstico em uma situação similar, caso em que o diálogo enfim se completará ${ }^{21}$.

De outro lado, a interpretação corretiva consiste no ajustamento de sua jurisprudência ao corpus iuris interamericano e, em especial, à jurisprudência da Corte IDH. Ela ocorre quando, diante de determinação direta, decorrente de decisão condenatória da Corte IDH, o Estado-parte ajusta sua jurisprudência ao direito convencional. Assim, nessa modalidade de diálogo os juízes ou tribunais domésticos "sacan las consecuencias de una condena por la CIDH [...], lo que genera un cambio en la jurisprudencia nacional, la que rectificará su jurisprudencia y practicará una interpretación conforme al derecho convencionap'22.

Trata-se de modalidade de interpretação conforme o corpus iuris interamericano e que se afigura, inclusive, como obrigatória ao Estado-parte, com base no princípio do "pacta sunt servanda" (arts. 26 e 27 da Convenção de Viena sobre o Direito dos Tratados) combinado com o art. 68.1, da CADH, segundo o qual "os Estados-partes na Convenção comprometem-se a cumprir a decisão da Corte em todo caso em que forem partes" 23 .

Outra modalidade de diálogo ascendente entre jurisdições é a interpretação recetiva, ocorrendo quando o Judiciário doméstico se utiliza da jurisprudência da Corte IDH para fundamentar sua decisão. Nesse caso, o juiz ou tribunal nacional pode invocar tanto as decisões da Corte IDH proferidas no exercício de sua jurisdição contenciosa quanto os pareces oriundos de sua competência consultiva. Neste caso, diferentemente do que ocorre na interpretação corretiva, o juiz doméstico não tem o

l'bonneur de Jean-Claude Gautron: Les dynamiques du droit européen en début du siècle (Paris: Ed. A. Pedone, 2004), 216.

${ }^{21}$ Humberto Nogueira Alcalá, "Diálogo interjurisdiccional y control de convencionalidad”, 511-553.

${ }^{22}$ Humberto Nogueira Alcalá, "Diálogo interjurisdiccional y control de convencionalidad”, 511-553.

23 "Convenção Americana sobre Direitos Humanos", Organização dos Estados Americanos (OEA), acesso em setembro 15, 2017, www.cidh.oas.org/basicos/portugues/c.convencao_americana.htm. 
seu país no polo passivo da demanda citada. Essa modalidade de diálogo é obrigatória, em razão da eficácia erga omnes da ratio decidendi das decisões da Corte $\mathrm{IDH}^{24}$.

Entende-se que todas as modalidades de interpretação judicial realizadas no âmbito nacional até aqui citadas são bem-vindas no sistema interamericano, podendo ser consideradas como interpretações conformes ao sistema interamericano. Quanto a essas duas últimas, viu-se, inclusive, que se afiguram obrigatórias ante o duplo caráter vinculante das decisões da Corte IDH.

Já na hipótese da interpretação neutralizadora, tem-se uma estratégia do Poder Judiciário nacional em se eximir do cumprimento do direito convencional, mediante uma exegese forçada do corpus iuris regional. Ela tem por finalidade falsear a conformidade entre a normativa e atuação estatal em face dos compromissos regionais e internacionais assumidos pelo Estado-membro. Essa modalidade interpretativa "muestra una falta de sinceridad por una de las partes que participa del diálogo"25 e constitui o que Sudre ${ }^{26}$ denomina de uma "estratégia de neutralização" do direito convencional, levada a cabo por uma releitura da lei nacional a fim de forjar uma adequação entre o direito interno e a norma regional ${ }^{27}$.

Nas palavras de Dubois ${ }^{28}$, “l'interprétation neutralisante joue sur une apparente soumission du juge national aux fins de préserver le droit national contraire au droit européen" ou, no caso

\footnotetext{
${ }^{24}$ Um exemplo em que este aspeto deveria ter sido observado é o caso julgado pelo STF em 24 de abril de 2010, referente à invalidade da Lei no 6.683, de 28 de agosto de 1979 (Lei de Anistia). Se o STF, naquela ocasião, houvesse adequado sua jurisprudência aos delineamentos claros e iterativos da Corte IDH (que, como visto, já em 2006, havia condenado o Chile no caso Almonacid Arellano) a respeito dessa matéria, teria, quem sabe, evitado ou, ao menos, amenizado a condenação do Brasil no sistema interamericano, ocorrida pouco tempo depois, em 24 de novembro do mesmo ano, no caso "Guerrilha do Araguaia" (caso Gomes Lund).

${ }^{25}$ Humberto Nogueira Alcalá, "Diálogo interjurisdiccional, control de convencionalidad y jurisprudencia”, 95.

${ }^{26}$ Frédéric Sudre, "A propos du "dialogue des juges"”, 210.

${ }^{27}$ Nas palavras originais do autor, a interpretação neutralizadora constitui uma "stratégie de contournement ou d'évitement, visant à neutraliser l'interprétation européenne en créant, par une interprétation un peu 'forcée' du droit national, voire par une réécriture de la loi, un rapport d'adéquation entre le droit interne et la norme européenne" (Frédéric Sudre, “A propos du “dialogue des juges"”, 210). Tradução livre: "estratégia de evasão, visando neutralizar a interpretação Europeia pela criação de uma interpretação um pouco 'forçada' da legislação nacional, que na realidade quer reescrever a lei em adequação do direito interno e a norma europeia".

${ }^{28}$ Julien Dubois, "La neutralisation: Dialogue des juges et interprétation neutralizante", in Le dialogue des juges (Montpellier: Institut de Droit des Droits del L’Homme. Cahiers de L’IDEDH Nº 11, 2007).
} 
brasileiro, contrário ao direito interamericano. Segundo Alcaláa ${ }^{29}$, a interpretação neutralizante pelo judiciário doméstico possui dois objetivos: a) validar lei nacional que contraria direito garantido por norma convencional conforme o entendimento da Corte regional; b) obter uma margem de apreciação em matéria não sujeita à margem de apreciação nacional.

Por fim, tem-se a interpretação discordante, que decorre de algo que é intrínseco a qualquer diálogo, isto é, a possibilidade de uma parte não concordar com a outra. Nesse passo, pode ocorrer de o judiciário nacional, de boa-fé, não aplicar a diretriz jurisprudencial da Corte regional, por entender que ela não está correta. Isso pode ocorrer, por exemplo, em razão de o tribunal doméstico entender que a Corte IDH não considerou, em determinada decisão, as implicações que a proteção de um direito humano poderia ocasionar a outro direito humano igualmente protegido.

Diante de tal situação, o tribunal nacional, ao apreciar caso análogo, pode realizar um diálogo interjurisdicional que, para ser legítimo, deve ser "franco, leal y de buena fe", devendo, então, expressar "razonadamente su desacuerdo con la CIDH, explicando los motivos del desacuerdo en el respectivo fallo" 30 , sempre cabendo, ainda, a possibilidade de a questão chegar à jurisdição interamericana e ser reexaminada pela Corte IDH.

Entende-se, nesse sentido, que a interpretação discordante, desde que feita de boa-fé, pode constituir-se em uma forma dialogal importante para a evolução do corpus iuris interamericano. Isto porque a Corte IDH não está isenta do erro e, portanto, negar a possibilidade de um questionamento razoável de sua jurisprudência seria contrário à própria ideia de diálogo judicial.

Ainda assim, é importante ter-se presente que as decisões da Corte IDH vinculam os Tribunais nacionais, sem prejuízo, contudo, de novos diálogos mudarem o cenário jurisprudencial ${ }^{31}$.

Feitas essas considerações acerca do diálogo interjurisdicional, passa-se, na sequência, a analisar como se deu esse diálogo, por parte do Supremo Tribunal

\footnotetext{
${ }^{29}$ Humberto Nogueira Alcalá, "Diálogo interjurisdiccional, control de convencionalidad y jurisprudencia”, 57-140.

${ }^{30}$ Humberto Nogueira Alcalá, "Diálogo interjurisdiccional y control de convencionalidad”, 542.

${ }^{31}$ Humberto Nogueira Alcalá, "Diálogo interjurisdiccionaly control de convencionalidad”, 542.
} 
Federal, no julgamento envolvendo a hierarquia dos Tratados Internacionais de Direitos Humanos (ou seja, a relação entre o direito interno e o direito internacional), tema da mais alta relevância para a consolidação do sistema interamericano no âmbito da realidade brasileira.

\section{Conclusão}

A internacionalização dos direitos humanos é um fenômeno que, paralelamente à conformação da noção de Estado Democrático de Direito, no âmbito interno, se recrudesce no contexto do segundo pós-Guerra, tendo como escopo evitar que se repetissem as gravíssimas violações a direitos perpetradas pelos regimes totalitários. Esse processo influencia, por sua vez, o surgimento dos chamados sistemas regionais de proteção dos direitos humanos, dentre os quais se encontra o Sistema Interamericano.

Nesse sentido, um papel relevante é cumprido pela previsão, constante no art. 2. ${ }^{\circ}$ da CADH, que determina aos Estados-partes a obrigação de adequar o seu direito interno às disposições da Convenção. Ou seja, diante do rol de direitos estabelecidos na $\mathrm{CADH}$, o Estado-parte assume a obrigação de respeitar e de assegurar o livre exercício desses direitos, comprometendo-se, ainda, a adotar não só todas as medidas legislativas indispensáveis a esta finalidade, como também a adotar outras que se mostrem necessárias para garantir efetividade aos direitos e liberdades nela compreendidos

Daí resulta, igualmente, o dever de os tribunais nacionais utilizarem o corpus iuris interamericano como fundamento para suas decisões, aspecto que conduz ao fato de que os magistrados estão vinculados a uma pluralidade de fontes, tanto de direito interno quanto de direito externo, cabendo-lhes a tarefa de compatibilização e de harmonização desses dispositivos. É neste contexto, por sua vez, que ganha relevo a figura do assim chamado "diálogo jurisdicional", enquanto instrumento para a adequada proteção dos direitos humanos e fundamentais em uma ordem jurídica complexa, caracterizada pela pluralidade normativa. 
O diálogo interjurisdicional deixa de lado o state approach, identificado com a ideia de soberania nacional, para assumir uma feição de human rights approach, centrado na primazia dos direitos humanos e pela permeabilidade do Direito mediante o diálogo entre jurisdições, que pressupõe uma sinergia entre os diversos juízes e tribunais, em busca da evolução do Direito, deslocando o seu foco da perspectiva de hierarquia entre os órgãos judiciais, que, em conjunto, devem alcançar soluções para os diferentes desafios jurídicos, notadamente na seara dos direitos humanos.

Quando esse diálogo ocorre entre tribunais ou juízes cujas decisões não são vinculantes de um para o outro, tem-se um diálogo interjurisdicional horizontal. É o que ocorre, por exemplo, no fecundo diálogo entre a Corte IDH e a Corte Europeia de Direitos Humanos, responsável pela evolução de ambas as jurisdições. Em casos tais, o diálogo ocorre de modo aberto e espontâneo, livre de qualquer vinculação jurídica. Já o diálogo vertical ocorre quando um dos tribunais ou juízes presentes no diálogo está vinculado às decisões proferidas pelo outro, como ocorre na relação entre a Corte IDH e os tribunais nacionais dos países que, assim como o Brasil, tenham reconhecido a obrigatoriedade de sua jurisdição.

É possível, ainda, neste contexto, falar-se de um diálogo vertical ascendente (quando ele se inicia no âmbito do órgão jurisdicional vinculado) e de um diálogo vertical descendente (quando é provocado pelo órgão judicial que detém a última palavra, em direção aos juízes e tribunais que a ele se vinculam). 



\title{
Emendas parlamentares e federalismo brasileiro: a governança e governabilidade e sua interconexão com a viabilidade orçamentária a partir da subsidiariedade
}

\author{
Ricardo Hermany*
}

RESUMO: A governança e governabilidade remetem para a análise da capacidade do sistema político de produzir e gerenciar políticas públicas, dessa maneira, se o governo contar com o apoio da sociedade ele detém a governabilidade, inserindo-se nos aspectos políticos do Estado. Assim, por meio da estratégia metodológica dedutiva e bibliográfica, o estudo objetiva verificar as relaçoes entre os poderes Executivo e Legislativo, bem como o desafio da governabilidade, para posteriormente analisar os mecanismos das emendas parlamentares e o orçamento impositivo e, ao final, observar a desigualdade orçamentária e a subsidiariedade no federalismo brasileiro.

PALAVRAS-CHAVE: emendas parlamentares - governança - governabilidade - gestão orçamentária - federalismo.

ABSTRACT: Governance and governance refer to the analysis of the capacity of the political system to produce and manage public policies, so that if the government has the support of society, it retains governance, inserting itself in the political aspects of the State. Thus, through the methodological deductive and bibliographical strategy, the study aims to verify the relations between the executive and legislative branches, as well as the governance challenge, to later analyze the mechanisms of parliamentary amendments and the tax budget, and in the end observe the inequality and budget subsidiarity in Brazilian federalism.

KEYWORDS: parliamentary amendments - governance - governability - budget management - federalism.

\footnotetext{
* Professor do Programa de Pós-Graduação em Direito da Universidade de Santa Cruz do Sul - UNISC. Doutor em Direito pela Universidade do Vale do Rio dos Sinos - UNISINOS, com estágio pós-doutoral na Universidade de Lisboa (bolsa CNPq).
} 


\section{Introdução:}

A governança e governabilidade começaram a ser mais debatidas depois das crises econômicas que ocorreram nos anos 70 e 80 em países em desenvolvimento. O Estado passa a refletir sobre as relações sociais, abrindo espaço de discussão em sua agenda política, criando uma articulação que passa a o sustentar. A partir disso, os conceitos de governança e governabilidade refletem para uma análise da capacidade do sistema político de produzir e gerenciar políticas públicas. Dessa maneira, a conceituação de governabilidade é muito mais interligada à capacidade política de governar, sendo relacionada com o exercício do poder, como também as condições materiais que devem existir para que determinado governo possa exercer as suas funções.

A governança fica vinculada a gestão de recursos e a capacidade de implementar políticas públicas. A organização do sistema orçamentário do Brasil tem previsão na Constituição e tem a elaboração com base na estrutura de três leis ordinárias de forma hierárquica, a Lei do Plano Plurianual (PPA), a Lei de Diretrizes Orçamentárias (LDO) e a Lei Orçamentária Anual (LOA). Ainda, pela leitura da Constituição, identifica-se que esse sistema possui inicio com a elaboração do PPA.

Dessa forma, quanto a esses instrumentos preconizados (PPA, LDO e LOA), permeia uma lógica institucional fragmentada, reproduzindo-se nos programadas definidos no PPA e na maneira de distribuição de recursos. No processo de elaboração do orçamento, a supremacia do Executivo se mantém, com prerrogativas de propor e decidir sobre a execução do gasto orçamentário ora aprovado. Quanto às emendas parlamentares, como forma de participação política, demonstrou-se permeável frente aos interesses e práticas clientelistas do Estado, o que envolve também uso irregular de recursos públicos.

Diante das relações entre os poderes Executivo e Legislativo, a finalidade do estudo perpassa por questões de governança e governabilidade, bem como pelos mecanismos das emendas parlamentares e do orçamento impositivo, para ao final verificar as emendas parlamentares no federalismo brasileiro, realizando uma discussão sobre a desigualdade orçamentária e as potencialidades a partir de uma perspetiva alicerçada na subsidiariedade administrativa interna. 


\section{Governança e governabilidade: as relações entre Executivo e Legislativo e o desafio da governabilidade}

A ideia de democracia como um fim a ser atingido, insere o Estado em uma posição de identificador dos diversos interesses e necessidade de abertura política ao diálogo dos atores. O Estado passa, então, a refletir as complexas relações sociais que o percorrem; abre espaço para a discussão da agenda política e cria uma articulação institucional que passa a sustentá-lo. Estes padrões de articulação e cooperação entre atores sociais, políticos e arranjos institucionais, passam a coordenar e regular a gestão pública ${ }^{1}$.

Diante desse quadro, surge a ideia de reformulação do modelo político de Estado, o qual deve ter como base a complexidade do sistema social contemporâneo. Quanto à restrição da atuação do Estado como mero produtor de direitos, demonstrando a nova urgência que se lhe impõe, qual seja, a articulação e regulamentação de políticas públicas. Neste aspeto, ressalta o papel de coordenação e cooperação das diversas áreas governamentais no sentido de buscarem conjuntamente o atendimento das demandas sociais ${ }^{2}$.

Dentro dessa conceção, governabilidade e governança são elementos que embora tenham conceituação distinta, tornam-se complementares, servindo de elo de ligação entre as diversas ações estatais. Assim sendo, é possível afirmar que o termo governabilidade refere-se às condições sistêmicas mais gerais sob as quais se dá o exercício do poder numa determinada sociedade. Governabilidade, neste diapasão, está ligada aos aspetos de construção do poder político e da gestão; liga-se aos variados níveis de exercício deste poder ${ }^{3}$.

Então, tendo como base as ideias de Maria Helena de Castro Santos, é possível afirmar que a conceituação de governabilidade leva em consideração os impactos que

\footnotetext{
${ }^{1}$ De acordo com Rafael Rocha Parente. "Executivo e Legislativo na alocação orçamentária: um estudo de caso sobre o programa oferta de água” (Phd Diss. Universidade de Brasília, 2014).

${ }^{2}$ Assevera Maria Helena de Castro dos Santos, "Governabilidade, governança e democracia: criação de capacidade governativa e relaçôes executivo-legislativo no brasil pós-constituinte", Dados -Revista de Ciências Sociais 40,3 (1997).

${ }^{3}$ Assim, cfr. Maria Helena de Castro dos Santos, "Governabilidade, governança".
} 
se desenvolvem sobre a gestão pública, tais como as características gerais do sistema político, a forma de governo, as relações entre os poderes, os sistemas partidários e o sistema de intermediação de interesses.

A manipulação desses fatores não conduz a um conceito seguro e acabado, mas demonstra a possibilidade de se verificar a sua própria existência dentro da gestão pública. Se a arquitetura institucional de determinado governo não dispõe de mecanismos capazes de conjugar os diferentes impactos que se debruçam sobre o sistema de governo, tem-se então uma não-governabilidade; contudo, se estes mesmo fatores sejam coordenados e bem aproveitados dentro da gestão, tem-se a governabilidade materializada.

A ingovernabilidade ou não-governabilidade, então, vincula-se ao fato de existir uma sobrecarga de demandas e questionamentos que contaminam a performance da gestão. Daí então, ser possível afirmar que a governabilidade está ligada à manipulação e desenvolvimento dos mecanismos que determinado governo dispõe para o exercício do poder político e construção da gestão ${ }^{4}$.

Por outro lado, a expressão governança faz referência aos resultados obtidos sobre a manipulação dos mecanismos políticos que se apresentam à disposição do gestor público. O termo tem origem nas publicações do Banco Mundial datadas da década de 80, quando a entidade passou a adotar critérios materiais para a concessão de estímulos financeiros aos países em desenvolvimentos. Assim, governança (governance) passa a identificar-se com sinônimo de bom governo, como aquele onde se mostra possível a criação e manutenção de ambiente que favoreça o desenvolvimento equitativo, forte e viável ao desenvolvimento de políticas públicas ${ }^{5}$.

Essas afirmações podem ser comprovadas mediante a descrição a respeito dos requisitos elencados pelo Banco Mundial como diretrizes para o estabelecimento de critérios materiais na verificação do bom governo. Neste sentido, os parâmetros propostos passam pela i) delimitação de um de regime político formal; ii) pela existência de processos legitimadores da gestão dos recursos econômicos e sociais e

\footnotetext{
${ }^{4}$ De acordo com, cfr. Maria Helena de Castro dos Santos, "Governabilidade, governança".

${ }^{5}$ Cfr. Maria Helena de Castro dos Santos, "Governabilidade, governança".
} 
iii) pela verificação da capacidade dos governos em formular e implementar políticas públicas $^{6}$. Vem daí a necessidade de se criarem mecanismos e procedimentos que rapidamente oportunizem uma negociação e solucionem os conflitos institucionais, evitando que o sistema político entre me crise.

Então, a solução que o próprio sistema encontra é o estabelecimento de mútuas transações. Ao oportunizar a troca e a concessão de apoio parlamentar, criase a chave para o entendimento das transações entre Executivo e Legislativo. Com respeito às causas de (in)governabilidade no ambiente democrático brasileiro, elas estão intimamente ligadas ao equilíbrio entre a autoridade das instituições de governo e à força das instituições de oposição ${ }^{7}$. Quando esta equação pesa mais para um lado do que para outro, tem-se então uma não governabilidade, a qual pode muito bem ser demonstrada pela impossibilidade de coalizão a todas legendas partidárias.

\section{O mecanismo das emendas parlamentares e o orçamento impositivo}

A organização do sistema orçamentário nacional possui previsão constitucional; sua elaboração tem como base a estrutura hierarquizada de três leis ordinárias: a Lei do Plano Plurianual (PPA), a Lei de Diretrizes Orçamentárias (LDO) e a Lei Orçamentária Anual (LOA). A partir da leitura do art. ${ }^{\circ} 165$ da Constituição Federal da República do Brasil, é possível identificar que o sistema orçamentário nacional tem início com a elaboração do PPA. Esta lei é um dispositivo abrangente, com duração de quatro anos; sua função principal é a fixação de diretrizes, objetivos e metas para os investimentos públicos e para as despesas que possuam duração continuada, descritas como aquelas com duração igual ou superior a dois anos do exercício financeiro. $\mathrm{O}$ PPA é, portanto, um instrumento de planejamento de longo prazo.

Seguindo a análise sistemática da elaboração orçamentária, após aprovado o PPA, tem-se a análise da LDO. A função primordial da LDO é fixar os parâmetros

\footnotetext{
${ }^{6}$ André Borges "Governança e política educacional: A agenda recente do banco mundial', Revista Brasileira de Ciências Sociais 18, 52 (2003).

7 Fábio Wanderley Reis, “Governabilidade, Instituições e partidos”, Novos Estudos 41 (1995).
} 
gerais para orientação do orçamento do ano seguinte, estabelecendo suas metas e prioridades. Diferentemente do PPA que tem validade por quatro anos, a LDO possui validade anual, destinando-se ao exercício financeiro de cada ano ${ }^{8}$.

Aliada a diretrizes gerais traçadas no PPA e aos parâmetros delimitados na LDO, encontra-se a terceira peça orçamentária, a Lei de Orçamento Anual- LOA. Assim como a LDO, a LOA também possui vigência anual, entretanto sua função principal é estimar a receita e fixar a despesa para o exercício financeiro. A elaboração orçamentária, portanto, tem um nítido processo de planejamento no qual o PPA contribui com as diretrizes gerais, indicando os rumos político-administrativos a serem tomados, fixando as prioridades e os principais programas de cada ministério, estabelecendo metas qualitativas e quantitativas. O tema proposto no PPA diz respeito a ideia global da consistência fiscal e direcionamento das políticas públicas prioritárias, traduzindo-se em importante espécie legislativa cuja atribuição primordial é consagrar o planejamento e a continuidade na gestão pública, entendido este último princípio como a necessidade das obras e serviços não sofrerem descontinuidade com a troca de gestão.

A partir daí cabe à LDO especificar, ano após ano, quais as metas descritas no PPA serão realizadas mediante o enquadramento das prioridades às realidades fiscal e financeira do governo. A LDO tem como objetivo a manutenção da política fiscal do governo, no sentido de promover a gestão equilibrada dos recursos públicos, de forma a assegurar a manutenção da estabilidade econômica, o crescimento sustentado, a distribuição da renda e prover adequadamente o acesso aos serviços públicos universais. Por fim, o planejamento orçamentário encerra-se com a promulgação da LOA. Enquanto o PPA traça as diretrizes gerais e a LDO estabelece as metas a serem atingidas, por sua vez, a LOA demarca a execução prática do orçamento.

A composição do projeto da LOA pode ser dividida em três partes gerais. Em um primeiro momento será traçado o Orçamento Fiscal, onde serão incluídos os três

\footnotetext{
8 “A PEC do Orçamento Impositivo”, Marcos José Mendes e Fernando Alvares Correa Dias, Acessado em maio 14, 2016, https://www12.senado.leg.br/publicacoes/estudos-legislativos/tipos-de-estudos/ textos-para-discussao/td-149-a-pec-do-orcamento-impositivo.
} 
Poderes da União, a administração indireta, fundos e fundações mantidos pelo poder público. Posteriormente tem-se a fixação do Orçamento da Seguridade Social, o qual compreende a previdência social, a assistência social e saúde; abrangendo todas as entidades dos ministérios que executam tais funções, inclusive a administração indireta, fundos e fundações mantidos pelo poder público. Por fim, há a fixação do Orçamento de Investimento das empresas estatais, aquelas em que a União detenha a maioria do capital social com direito a voto?

A LOA, conforme dispõe o art. ${ }^{o} 165$ da CFRB, é uma lei de lei de iniciativa privativa do Poder Executivo. Após encaminhado e aprovado pelo Congresso, o projeto volta para sanção presidencial. Uma vez promulgada, a LOA é executada por meio da edição de decretos de programação financeira, nos quais fica estabelecido o cronograma de liberação dos recursos e os limites de despesa de cada órgão e unidade orçamentária.

Todo esse procedimento tem início no Ministério do Planejamento que, mediante um levantamento acerca da estimativa de receitas, desconta os valores a serem empregados em despesas obrigatórias e o valor fixado na LDO para o resultado primário. O que resta será destinado às despesas não obrigatórias de custeio e investimento. O Ministério do Planejamento, de posse deste valor, fixa cotas de despesas para cada ministério, repassando uma proposta de orçamento ao Presidente da República, para envio ao Congresso ${ }^{10}$.

É justamente neste ponto que a governabilidade começa a ser testada e posta em prática. Por ser formado a partir de uma diversidade de propostas, oriundas dos diversos ministérios, o processo de elaboração da LOA é sujeito a uma intensa negociação política. A coalizão política faz com que os gabinetes ministeriais sejam ocupados muitas vezes, senão diretamente por parlamentares, por indicações da base

\footnotetext{
9 "Sistema orçamentário brasileiro: Planejamento, equilíbrio fiscal e qualidade do gasto público", Marcos José Mendes, Acessado em agosto 3, 2016, https://www12.senado.leg.br/publicacoes/ estudos-legislativos/tipos-de-estudos/textos-para-discussao/td-39-sistema-orcamentario-brasileiroplanejamento-equilibrio-fiscal-e-qualidade-do-gasto-publico.

10 "O Orçamento Público e a Automação do Processo orçamentário", Laerte Ferreira Morgado, Acessado em julho 11, 2016, http://www12.senado.leg.br/publicacoes/estudos-legislativos/tipos-deestudos/textos-para-discussao/td-85-o-orcamento-publico-e-a-automacao-do-processo-orcamentario.
} 
de governo com assento no parlamento. Assim, cada ministério procura aumentar sua dotação, o que significa mais poder político, pressionando o Ministério do Planejamento e a Presidência da República quando da elaboração do projeto da $\mathrm{LOA}^{11}$.

Até a edição da EC-86/2015, as emendas parlamentares não possuíam a obrigatoriedade de cumprimento; o contingenciamento de receitas realizado mediante decretos poderia ou não as tornar efetiva. Contudo, a alteração constitucional, tornou impositiva a aplicação das programações contidas nas emendas individuais.

Essa profunda modificação na aplicação das regras orçamentárias resultou de dois fatores centrais ${ }^{12}$. O primeiro refere-se ao descontentamento parlamentar com os baixos níveis de execução das emendas individuais, fato evidenciado na aprovação com ampla margem de votos da EC-86/2015. Em segundo, a cultura e a prática administrativa sempre consideraram que os orçamentos públicos possuíam caráter meramente autorizativo, garantindo ao gestor uma ampla discricionariedade na sua efetiva execução.

Porém, com EC-86/2015novas disposições foram acrescidas aos arts. ${ }^{\text {os }} 165$ e 166 da Constituição Federal, determinando a obrigatoriedade de execução das programações orçamentárias derivadas de emendas individuais. $\mathrm{O}$ orçamento impositivo, em síntese, traz a ideia de que a execução da lei orçamentária, no que tange às programações incluídas ou acrescidas por meio de emenda individual, é obrigatória, e não apenas facultativa. A execução orçamentária torna-se, portanto, um dever do gestor; somente podendo ser afastada quando forem comprovados e fundamentados impedimentos técnicos ou legais.

O sentido da EC-86/2015 é de que a metade do valor das emendas apresentadas deva ser destinado às ações e serviços públicos de saúde, assim, além de vincular o objeto das emendas individuais, a alteração constitucional passa a constituir um piso mínimo para a saúde. Dentro desta limitação de objeto, a emenda constitucional

\footnotetext{
${ }^{11}$ Cfr. Maria Helena de Castro dos Santos, "Governabilidade, governança".

12 "O Orçamento impositivo das Emendas Individuais - Disposições da Emenda Constitucional no 86, de 2015, e da LDO 2015”, Eugênio Greggianin e José de Ribamar Pereira da Silva, Acessado em agosto 3, 2016, http://www2.senado.leg.br/bdsf/bitstream/handle/id/509462/OED0016.pdf?sequence=1.
} 
estipulou que o patamar máximo destinado ao orçamento impositivo dever ser de $1,2 \%$ (um inteiro e dois décimos por cento) de toda receita líquida corrente e seu contingenciamento só pode ser realizado proporcionalmente ao não alcance das metas fiscais.

\section{As emendas parlamentares e o federalismo brasileiro: uma discussão sobre a desigualdade orçamentária e a subsidiariedade na gestão pública municipal}

As emendas parlamentares, previstas no art. ${ }^{\circ} 169$ da Constituição da República Federativa do Brasil, a partir da alteração realizada pela EC 85/2015, passaram a ter o limite financeiro correspondente a 1,2\% (um inteiro e dois décimos por cento) da receita corrente líquida prevista no projeto de orçamento encaminhado pelo Poder Executivo. No projeto da LOA 2016, o valor por parlamentar ficou fixado na ordem de $\mathrm{R} \$ 15.342 .437,00$ (quinze milhões trezentos e quarenta e dois mil quatrocentos e trinta e sete reais $)^{13}$.

Além do procedimento de emendas individuais, existem também as emendas de bancada. Ainda que a proposição individual de emendas ao orçamento tenha como ideal o favorecimento regionalizado, a determinação de que a metade das propostas esteja direcionada à área da saúde, inibe, ainda que de forma frágil e insuficiente, a utilização clientelista do mecanismo de emendas com o único propósito de favorecimento eleitoral, com a consequente violação do princípio da igualdade.

É por meio dessa conexão eleitoral que grande parte dos Municípios brasileiros obtém recursos designados a critério do parlamentar - deputado federal ou senador - numa prática que viola os princípios da igualdade, aplicado no caso aos entes federados, e da subsidiariedade, considerando que a decisão de aplicação fica distante da população beneficiária da política pública. A ideia de extinção do mecanismo

\footnotetext{
13 "Congresso Nacional. Manual de Emendas Parlamentares para Orçamento da União 2016b", Câmara dos Deputados Federais, Acessado em agosto 10, 2016, http://www2.camara.leg.br/atividadelegislativa/orcamentobrasil.
} 
das emendas parlamentares está extremamente adequada aos pressupostos teóricos dos princípios acima referidos, na medida em que o mecanismo de distribuição de receitas passaria a se submeter aos índices de redistribuição do Fundo de Participação dos Municípios - proposta da Confederação Nacional de Municípios (CNM) -, que possui critérios absolutamente objetivos, ao mesmo tempo em que a determinação da aplicação do recurso seria da própria administração local, registrando-se a necessidade de uma ampla interação com a comunidade, por meio de audiências públicas, na esteira do que preconiza a dimensão horizontal da subsidiariedade, princípio implícito na Constituição Brasileira.

\section{Considerações finais}

Diante do exposto, verificou-se a impossibilidade de conciliação de benefícios democráticos proporcionados pelo multipartidarismo, pois quando se trata de presidencialismo de coalizão a governabilidade fica atingida pela existência inconciliável de interesses e disputas entre partidos. É o que se verifica na aferição do desenho institucional no sistema político do Brasil, sendo causa da (in)governabilidade, que vem ligada ao equilíbrio das autoridades institucionais do governo e a força oposicionista. Vale salientar que esta equação não é equilibrada, o que causa uma não governabilidade, demonstrada pela impossibilidade de coalização nas legendas partidárias.

As emendas parlamentares individuais, criticadas ao longo do texto, não podem ser entendidas somente como uma forma ou mecanismo de orçamento e financiamento, e a sua execução não se justifica apenas pelas variáveis setoriais diante de ações planejadas do poder Executivo do país, muito menos na busca por ampliar as ações que tem como finalidade a redução de desigualdades. Muitas das explicações para o caráter da execução de emendas parlamentares se situam nas relações entre os poderes, assim como na busca por construir a governabilidade para a atuação do poder Executivo federal.

Dessa forma, muitas emendas parlamentares acirram interesses distintos e 
tendem a reforçar algumas práticas que se chocam com os propósitos de fortalecer os investimentos de cunho federal na perspectiva de redução de desigualdades. Por esta razão a extinção das emendas individuais permitiria um tratamento igualitário nos critérios objetivos de repartição das receitas tributárias. Com a proposta da Confederação Nacional de Municípios, os Municípios que não possuem uma proximidade com parlamentares eleitos também teriam acesso a estes recursos, o que respeitaria os princípios da igualdade - aqui em nível institucional - e da subsidiariedade, implícito na ordem jurídica brasileira. 



\title{
Fundamentos epistêmicos sobre a importância da participação social no enfrentamento da corrupção
}

\author{
Rogério Gesta Leal ${ }^{*}$
}

RESUMO: O presente texto busca enfrentar alguns fundamentos filosóficos e politicos da participação social no âmbito da Administração Pública, a partir de pressupostos fundacionais da Democracia sob a perspetiva da deliberação pública, e como isto pode auxiliar no combate à Corrupșão.

PALAVRAS-CHAVES: Democracia-participação social-Administração Pública-corrupção - responsabilidade politica.

ABSTRACT: The present text seeks to address some philosophical and political foundations of social participation within the scope of Public Administration, based on the foundational presuppositions of Democracy from the perspective of public deliberation, and how this can help in the fight against Corruption.

KEYWORDS: Democracy - social participation - Public Administration - corruption - politic responsability.

\footnotetext{
* Professor Titular do Programa de Pós-Graduação em Direito da Universidade de Santa Cruz do Sul - UNISC e Professor do Mestrado em Direito da Fundação Escola Superior do Ministério Público do Rio Grande do Sul - FMP.
} 


\section{Notas introdutórias}

Pretendemos neste texto abordar alguns fundamentos da participação social na Gestão Compartida da Administração Pública relacionados à ideia de Democracia sob a perspetiva deliberativa, a partir do que entendemos que seja possível ampliar os horizontes das problematizações empíricas que estão a desafiar o enfrentamento de um grave problema global que é a Corrupção.

\section{Qual participação social e em que Democracia?}

Baudrillard já teve oportunidade de dizer que toda a nossa realidade se tornou experimental. Na ausência de destino, o homem moderno está entregue a uma experimentação sem limites sobre si mesmo ${ }^{1}$. Tais fenômenos não são ruis ou bons por si próprios - afinal estes são tempos de significados e sentidos cambientes, característica da Sociedade de Riscos mutante em que nos encontramos ${ }^{2}$. O problema, pois, não diz com negar realidades que nos são novas e distintas das quais estamos acostumados, mas avaliar a partir de que premissas nossas experiências com os outros se dão - na política, na economia, na cultura. Quais os parâmetros que estão a informar as condições e possibilidades destas novas realidades? ${ }^{3}$

\footnotetext{
${ }^{1}$ Jean Baudrillard, Simulacres et Simulations (Paris: Galilée, 1981). Ver também os textos: (i) Jean Baudrillard, La Société de Consommation (Paris: Denoël, 1970) e (ii) Jean Baudrillard, La Transparence du Mal (Paris: Denoël, 1978).

${ }^{2}$ Desde já nos afastamos aqui, quando falamos de Sociedade de Riscos, da ideia de "pós-modernidade" no sentido de ser possível descartar, neste mundo hipercomplexo, quaisquer regulamentações normativas da comunidade humana, sob o fundamento de que todos os tipos de vida se equivalem, que todas as sociedades são igualmente boas ou más, pois isto implicaria negar a possibilidade de estabelecermos juízos de valor críticos para debater seriamente questões relativas a modos de vida viciosos e virtuosos. Nos aproximamos, com isto, de Zygmunt Bauman, no sentido de ampliar a máxima potência as possibilidades de compreensão desta Sociedade atual, ainda moderna nas suas ambições e no seu esforço de modernização compulsiva, obsessiva, mas desprovida das antigas ilusões de que o fim da jornada estava logo adiante; ou seja, uma modernidade sem ilusões. Ver os já clássicos textos de Bauman: Zygmunt Bauman, Modernidade e Ambivalência (Rio de Janeiro: Jorge Zahar Editor, 1999); Bauman, Modernidade Liquida (Rio de Janeiro: Jorge Zahar Editor, 2000); Bauman, A riqueza de poucos beneficia todos nós? (Rio de Janeiro: Zahar, 2015).

${ }^{3}$ Ver a discussão que faz sobre isto, na perspetiva da filosofia política Klaus Von Beyme, Teoría política del siglo XX: de la modernidad a la postmodernidad (Madrid: Alianza Editorial, 1994).
} 
Por certo que algumas diretrizes vinculantes que estão a pautar nossas relações sociais e institucionais são jurídico-normativas - e são as que nos interessam mais neste trabalho -, constituídas a partir de historicidades as mais diversas e já incorporadas em nosso cotidiano. Estamos falando dos sistemas jurídicos (constitucional e infraconstitucional) vigentes. Mas não pode o debate sobre a Democracia se reduzir ao plano do jurídico, é muito mais que isto.

Claude Lefort já lembrava que, de todas as formas de sociedade conhecida, a Democracia distingue-se certamente pelo abandono da crença numa lei divina da qual o detentor da autoridade seria o representante, e isto porque, a partir da Idade Moderna (em especial) o espaço do poder político e de seu exercício, na medida em que não seja confundido com a vontade do Rei, da Igreja, dos Senhores Feudais, tão logo ninguém seja apto a ocupar a posição de um grande mediador e de um grande juiz de forma absoluta e sem razões de justificação e fundamentação legítimas, esse espaço será tacitamente reconhecido como um "espaço vaz̧io". ${ }^{4}$

Ou seja, por mais que tenhamos normas jurídicas regulando minimamente o exercício do poder pelos múltiplos protagonistas que constituem os espaços públicos nas Democracias Contemporâneas (sejam elas presidencialistas, parlamentaristas, republicanas ou monárquicas), fundamentalmente das autoridades públicas, isto jamais irá afastar as competições, lutas e conflitos de interesses próprios destes campos de atuação, muitos deles indenes aos sistemas normativos estatais, compreendendo a Democracia mais como fenômeno multifacetário do que como regime de governo com fórmulas prontas.

Vale lembrar as reflexões de Thomas Morus no particular, em seu texto clássico Utopia ${ }^{5}$, ao imaginar um Estado e uma Sociedade (enquanto co-constituídos) como um lugar que ainda não existe totalmente acabado, mas que presenta a felicidade e o bom governo de todos para todos. Este tipo ideal evidencia a marca processual do constante aperfeiçoamento das relações que possibilitam o fenômeno democrático.

\footnotetext{
${ }^{4}$ Ver os textos: (i) Claude Lefort, A Invenção Democráticy (São Paulo: Brasiliense, 1983); (ii) Claude Lefort, Pensando o político (Rio de Janeiro: Paz e Terra, 1991); (iii) Claude Lefort, Élements d'une critique de la bureaucratie (Paris: Éditions Gallimard, 1979).

5 Thomas Morus, Utopia (Brasilia: Unb, 2004).
} 
Fulano lembra da obra de Morus ao sustentar que: 'Tl titolo dell'opera suonava appunto: Dell'ottima forma di stato e della nuova isola Utopia. Vi si disegnava infatti un assetto politico, sociale, religioso che, certo, non poteva trovare alcun riscontro nella realtà storica del tempo e che tuttavia doveva pur proporsi come ideale e modello d'una società buona: un'ambiguità che, del resto, era già contenuta nel prefisso " $u$ " della parola "u-topia". Si tratta infatti di un prefisso che non ha facile traduzione. Viene di solito letto come contrazione del greco "ou" e dunque la parola può ben indicare l'idea di un "non-luogo", l'idea di uno stato inexistente e infine impossibile, solo immaginario. Ma il prefisso " $u$ " potrebbe anche leggersi come una contrazione del prefisso "eu" $e$ allora la parola significherebbe "felice-luogo": fuor di metafora, disegno di uno stato ideale che Moro, Gran Cancelliere alla corte di Enrico VIII, avrebbe contrapposto al mal costume politico dei suoi tempi. I due significati sono, a ben vedere, entrambi possibili e infine complementari”.

Na mesma direção, todavia com perspetiva já mais avançada em termos pragmáticos, há o trabalho de Karl Mannheim, Ideologia e Utopia, contrapondo-se aos ideais utópicos em sentido mais abstrato sobre o Estado e a Sociedade Ideais do novecentos, e estabelecendo a ideia deste Estado e Sociedade como princípio fundamental de organização das relações políticas enquanto concreta perspetiva de bem comum e critério de inspiração crítica para uma Sociedade melhor, portanto, dando relevo à participação dos cidadãos no processo de formatação de sua comunidade política.

Não esqueçamos Ernst Bloch, com seu Espírito da Utopia, no qual a consciência histórica é tomada não como espaço de desenhos imaginários, mas como inspiração e apelo a valores essenciais a uma crítica das contradições históricas (muitas delas baseadas em tensões inovadoras que se deixam inspirar por visões ideais e genéricas) que têm abalado Estado e Sociedade contemporâneos ${ }^{8}$.

Ainda cabe o registro de que, no modelo clássico de Democracia Antiga já havia o princípio de que o poder não deveria ser apropriado por qualquer um, embora seja

\footnotetext{
${ }^{6}$ Virgilio Melchiorre, "Per il ritorno di una coscienza utópica", Quaderni per il Dialogo e la Pace Anno X. (Abril - Junho, 2013): 05 Lembra o autor ainda que: La parola fu comunque assunta nel seguito per indicare $i$ disegni dell'immaginario politico volti all'ideazione di una forma perfetta e giusta di stato.

${ }^{7}$ Karl Mannheim, Ideología y Utopía: introducción a la sociología del conocimiento (México: Fondo de Cultura Económica, 1987).

${ }^{8}$ Ernst Bloch, The Spirit of Utopia (Standford: Standford University Press, 2000). Ver também Ernst Bloch, The Principle of Hope (Oxford: Basil Blackwell, 1986).
} 
atribuído à assembleia dos cidadãos, já que é poder comunitário que se edifica em prol do enfraquecimento da divisão social, nas Democracias hodiernas o exercício do poder depende sempre do conflito político de interesses, de crenças e de opiniões na Sociedade, razão pela qual, na dicção de Lefort, o poder político não remete a um além que seja imputável aos deuses ou a uma ordem do universo, nem a um aquém que seja inteiramente positivo?

Mas como enfrentar estes conflitos de interesses, crenças e opiniões na constituição de espaços e deliberações democráticas?

Não há uma fórmula única para tanto, mas possibilidades de composição no particular, partindo da premissa de que temos de aceitar que nossas sociedades estão marcadas por tais diferenças não como anomalias que precisam ser extirpadas em nome de um pensamento único, mas que é possível, a partir de estratégias e ações comunicativas voltadas ao entendimento - nem sempre consensual, edificar pactos civilizatórios de convívio com as diferenças, desde que não provoquem danos a terceiros.

Neste sentido a ideia de pluralismo razoável de Joshua Cohen ${ }^{10}$ é muito interessante, pois reconhece que a divergência persistente acerca, por exemplo, dos valores da escolha e da autodeterminação, da felicidade e do bem-estar, e da auto realização; das disputas sobre os méritos relativos das vidas prática e contemplativa, e a importância do compromisso pessoal e político; divergências sobre os pano de fundo filosófico e religioso dessas concepções valorativas, fazem parte das relações sociais em diferentes locais do globo terrestre, e temos de partir delas para pensar uma civilização inclusiva e democrática. Como diz o autor: "à parte o fato puro do desacordo, não existe nenhuma tendência à convergência gerada pelo exercício da razuão prática; além disso, não temos uma teoria das operações da razão prática que nos permita predizer a convergência entre moralidades abrangentes, nem consigo imaginar qualquer mecanismo social ou politico marginal atrativo que poderia produzir tal acordo"'1.

\footnotetext{
${ }^{9}$ Claude Lefort, The Political Forms of Modern Society: Bureaucracy, Democracy, Totalitarianism. (Cambridge: MIT Press, 1986), 38.

${ }^{10}$ Joshua Cohen, "Legitimidade e deliberação política", in A democracia deliberativa, org. Denilson Luis Werle e Rúrion Soares Melo (São Paulo: Editora Singular, Esfera Pública, 2007), 117.

${ }^{11}$ Cohen, Legitimidade e deliberação política, 117. Lembra ainda o autor que: "Este fato do pluralismo razoável
} 
Se é assim, contando ainda com o fato de termos parâmetros normativos dados pela civilização ocidental para os fins de demarcamos quais são os valores, princípios e objetivos que temos como Sociedade (ao menos como mínimo existencial) - como os Direitos Humanos e Fundamentais albergados e especificados no âmbito, por exemplo, das Constituições contemporâneas -, serão procedimentos de discussão, deliberação e escolhas públicas que vão definir a qualidade substancial e processual da Sociedade Democrática que vamos construir.

Então, os argumentos utilizados no raciocínio e debates públicos terão escalas de qualidade mínima em face dos níveis de aproximação com os Direitos Humanos e Fundamentais que conseguirão alcançar - claro, não sendo possível estabelecer aqui métricas matemáticas, mas podemos utilizar indicadores de proporcionalidade justificada, à moda Robert Alexy, por exemplo ${ }^{12}$.

A partir do ponderado, apreciamos a tese de Joshua no sentido de que podemos ter uma conceção de Democracia organizada em torno de ideais de justificação política. De acordo com tais ideais, justificar o exercício de poder político coletivo é proceder com base na argumentação pública - mais no sentido de raciocínio - livre entre iguais, configurando-se a Democracia também como estrutura de condições sociais e institucionais que facilita a discussão livre entre cidadãos iguais - proporcionando condições favoráveis de participação, associação

dá forma à concepção de cidadãos como pessoas livres e iguais que constitui parte da concepção de democracia que pretendo examinar aqui. Livres é dizer, que nenhuma visão moral ou religiosa abrangente fornece uma condição definidora de pertença à cidadania ou o fundamento da autorização para o exercício do poder político. Iguais é dizer que cada um é reconhecido como tendo as capacidades exigidas para participar na discussão em torno da autorização do exercício do poder",

${ }^{12}$ Ver nosso texto Rogério Gesta Leal, Estado, Administração Pública e Sociedade: novos paradigmas (Porto Alegre: Livraria do Advogado, 2012), assim como o texto Rogério Gesta Leal, "Aspectos Constitutivos da Teoria da Argumentação Jurídica: A Contribuição de Robert Alexy", in Dignidade Humana, Direitos Sociais e Não-Positivismo Incluso, org. Robert Alexy et al. (Florianópolis/SC: Qualis Editora e Comércio de Livros Ltda, 2015, v. 01), 319-369. Mesmo em tais condições, lembra Joshua, acertadamente que: "Certamente, a caracteriqação precisa das rą̃ões aceitáveis, e de seu peso apropriado, varia conforme as concep̧cões. Por esta raz̃ão, em geral nem mesmo um processo deliberativo ideal produzirá um consenso. Mas mesmo se há divergência, e a decisão é feita pela regra da maioria, os participantes podem recorrer a considerações que são, de modo geral, reconhecidas como tendo peso considerável. O próprio apoio da maioria valerá comumente como razãa para aceitar a decisão como legitima”. 
e expressão -, bem como vinculando a autorização para exercer o poder público a essa discussão ${ }^{13}$.

Esta postura já nos afasta de compreensões da comunidade política como dependente do compartilhamento de conceções morais ou religiosas do mundo - até porque isto negaria a importância de outra categoria e premissa fundamental adotada aqui que é a do chamado pluralismo razoável -, mas ao contrário, reclamamos que a Democracia deve estimular formas múltiplas de autonomia política, no sentido de que todos aqueles que são governados por decisões coletivas devem achar aceitáveis os fundamentos para essas decisões.

Então podemos sustentar, com Thomas Christiano, que a participação social efetiva na gestão do interesse público gera processos de depuração e aprimoramento do regime democrático, no sentido de que: (i) melhora a qualidade das decisões ao aperfeiçoar a compreensão dos cidadãos sobre sua sociedade e sobre os princípios morais que a devem regular; (ii) as leis dessas sociedades podem frequentemente tender a ser mais bem justificadas, do ponto de vista racional, aos olhos de seus cidadãos, do que naquelas sociedades que não passaram por um processo intensivo de deliberação sobre legislação; (iii) são aperfeiçoadas certas qualidades desejáveis nos cidadãos quando têm de participar do processo de deliberação, em especial as virtudes dos cidadãos ampliadas por tais processos ${ }^{14}$.

Agora, não podemos imaginar que tudo isto seja possível senão contando com posturas cognitivas e comunicativas coerenciais dos sujeitos que participam do

\footnotetext{
${ }^{13}$ Leal, Estado, Administração Pública e Sociedade, 122. Lembra o autor que são estes elementos que asseguram a responsividade e a accountability do poder político por meio das eleições competitivas e regulares, condições de publicidade, supervisão legislativa.

${ }^{14}$ Thomas Christiano, "Legitimidade e deliberação política", A democracia deliberativa org. Denilson Luis Werle e Rúrion Soares Melo (São Paulo: Editora Singular, Esfera Pública, 2007), 82. Ver também o texto do autor intitulado "The Authority of Democracy", The Journal of Political Philosophy 11,2 (2003). Registramos que o autor faz uma crítica muito pontual a concepção justificatória da Democracia articulada por Joshua Cohen e que referimos anteriormente, no sentido de que ela falharia em fornecer explicação convincente sobre a importância da deliberação pública na Democracia - com o que discordamos, mas não temos tempo de abordar isto neste trabalho. Remetemos a leitura para outro texto de Thomas Christiano, "Freedom, Consensus, and Equality in Collective Decision Making", Ethics 101,1 (outubro, 1990).
} 
debate público, ou seja, os interlocutores devem estar dispostos a também ouvir compreensivamente os demais participantes, no sentido de buscar, a partir dos melhores argumentos, acordos conjunturais, tendo presente que algumas condições qualitativas destes argumentos já estão dadas por aqueles parâmetros normativos referidos. Como novamente refere Thomas: "sob o pressuposto de que mentes instruidas dessa maneira formularão frequentemente melhores decisões e de que uma sociedade em que todos os seus membros participam no processo de discussão e debate serão capazes, pelo menos, de erradicar os preconceitos falsos de suas políticas, temos razões para pensar que uma sociedade que promove a deliberação pública tomará decisões melhores ${ }^{15}$ ".

E quando aquelas posturas exigidas dos cidadãos constituintes da Sociedade Democrática de Direito não estão presentes, seja por conta dos processos de desmotivação e apatia políticas participativas com níveis de consciência colaborativa aceitáveis provocados por relações perversas institucionais e interpessoais; seja em face da indiferença dos indivíduos para com o coletivo; seja por decorrência das manipulações lícitas e ilícitas que setores hegemônicos da Sociedade impõem a esta comunidade (mercado, crime organizado, fações políticas defensoras de interesses privados)? Então o Estado (Democrático de Direito) deve, a partir de políticas públicas de gestão compartida com todos os membros da comunidade, tomar providências positivas ${ }^{16}$.

\footnotetext{
15 Thomas Christiano, "Legitimidade e deliberação política", 86. Alerta o autor - e o faz bem - que: "Estas são afirmações modestas que apelam ao nosso senso comum, mas devemos lembrar que a evidência empírica para tais efeitos em larga escala da discussão pública é em geral tênue e nem toda ela é positiva."

${ }^{16}$ Inclusive para os efeitos de fazer valer na gestão compartida o princípio da diferença de John Rawls, no sentido ter a igualdade substantiva e processual como fundamento nuclear da Democracia, exigindose que as desigualdades estabelecidas ou sancionadas pela ação do Estado devam funcionar para a vantagem máxima dos menos favorecidos. Ver o texto de John Rawls, "The Idea of Public Reason Revisited", University of Chicago Law Review 64 (verão, 1997): 765-807. Ver também o excelente texto, sobre o tema, de Thomas M. Scanlon, What We Owe to Each Other. (Cambridge, Mass.: Harvard University Press, 1998).
} 


\section{Importância da participação social no combate à Corrupção}

Em interessante texto escrito há mais de 20 anos, Benjamin Barber já advertia para o facto de que o cenário mundial de então apontava claramente uma encruzilhada às Democracias contemporâneas: de um lado, as tendências centrípetas e de homogeneização da globalização, fomentadas pela fórmula Democracia + mercado; de outro lado, as tendências centrífugas ou de fragmentação dos tribalismos ou localismos de resistência aos processos de exclusão social criados pelas primeiras tendências, com maior incidência em países com níveis de desenvolvimento menores que os já amplamente desenvolvidos ${ }^{17}$.

Esta encruzilhada, dentre outros efeitos que produziu, gerou profundo impacto na relação entre instituições representativas democráticas e sociedade civil organizada, no sentido de fragilizar ainda mais os vínculos orgânicos de partidos políticos e governos instituídos com seus representados, insulando os espaços institucionais de exercício do Poder progressivamente, o que contribuiu, por muito tempo, para o desenvolvimento de ações corruptivas por parte dos atores políticos através das instituições a que pertenciam.

Ao lado disto, é preciso reconhecer que o Estado se encontra cada vez mais agrilhoado ao sistema econômico transnacional, abandonando seus cidadãos à afiançada liberdade negativa da competição mundial e limitando-se, quanto ao mais, a pôr, regularmente, à disposição do cenário político e econômico, infraestruturas que tornem atraente sua própria posição sob a perspetiva da rentabilidade. Daí a importância de se discutir sobre procedimentos e ajustes democráticos que conferem aos cidadãos a possibilidade de atuação política sobre suas condições sociais de vida, o que se tem esvaziado à medida que a matriz da Democracia Representativa perde funções e espaços de ação, sem que surjam, para tanto, equivalentes mecanismos de gestão do público, cada vez mais restrito aos termos de acepções corporativas de interesses privados ${ }^{18}$.

\footnotetext{
${ }^{17}$ Benjamin R. Berber, Jihad $\times$ MoWorld: how globalism \& tribalism are re-shaping the world (New York: Ballantine Books, 1996).

${ }^{18}$ Nesse sentido ver o texto de Martin Young, Inclusion and Democracy (Oxford: Masters, 2002), 64.
} 
Temos que a deliberação pública realizada fora do âmbito estatal constitui inexorável base de legitimação para ações políticas de gestão do interesse público e, por isto, deve permitir a todos os potencialmente envolvidos poder opinar e interagir comunicativamente antes que decisões sejam tomadas e executadas. Desta forma, a livre circulação da informação e do alongamento das oportunidades educativas erigir-se-iam em elementos nodais à esfera de autonomia dos protagonistas do espaço público, tendo como motivação a implementação de condições históricosociais que possibilitariam a emergência, expansão e transformação delas, centradas historicamente nas instituições tradicionais de representação política forjadas no âmago da experiência estatal moderna ${ }^{19}$.

Segundo a perspetiva de Habermas, a qual nos filiamos, um conjunto crescente de organizações e movimentos societais sempre podem enriquecer a comunicação e o debate nas sociedades contemporâneas, revitalizando de forma substantiva a esfera pública. Estes novos âmbitos estariam a permitir a articulação de uma pluralidade de enfoques culturais e sociais, o que levaria a reforçar a ideia de crítica e controle do poder - e da Corrupção - e aprofundar a Democracia, fazendo surgir, por sua vez, fatores de integração social alternativos, baseados no diálogo e não na dominação (ora simulada, ora explícita).

Mais contemporaneamente, autores como James Bohman têm dado continuidade a este tipo de debate ${ }^{20}$, sustentando que a deliberação e o consenso seriam termos chaves na hora de definir a Democracia e a política de governo ou de gestão, revelando-se fundamental que as razões de Estado e de cada grupo que o compõe possam resultar convincentes para o restante da cidadania, que tradicionalmente não participa de forma direta do governo ou da gestão, ao menos no plano executivo ou legislativo do seu evolver, sem que, para isto, ninguém seja obrigado a abdicar de suas próprias opiniões e conceções de bem.

\footnotetext{
${ }^{19}$ Como observa Jürgen Habermas, Mudança Estrutural da Esfera Pública (Rio de Janeiro: Civilização Brasileira, 1988), 39.

${ }^{20}$ James Bohman, Public Deliberation: Pluralism, Complexity, and Democracy (Boston: Madinson, 2002), 13. Ver também o texto James Bohman e William Regh, Deliberative Democracy: Essays on Reason and Politics (Cambridge, Massachusetts and London, England: The MIT Press, 1997).
} 
Neste modelo de deliberação, fundada na premissa de melhor formação e informação socialmente construída, a condição de cidadania restaria melhor preparada para a adoção de decisões relevantes, isto em face do modelo tradicional de representação política institucional moderna, em que os espaços de discussão, deliberação e execução, ocorreriam mediados por instrumentos e mecanismos por vezes artificiais, em termos de identidade e presentação social ${ }^{21}$.

Numa outra perspetiva, a deliberação pública, fundada em interlocução cotidiana pelos atores sociais que efetivamente estão envolvidos no processo político de constituição do espaço cívico e republicano da civilidade, poderiam ter também um efeito transformador das crenças e opiniões destes participantes ${ }^{22}$, e assim, produzirse-iam melhores decisões públicas, no sentido de serem refratárias das demandas da maior parte quantitativa da população atingida.

Agora, é preciso ter o discernimento de que a deliberação não é unicamente a busca por soluções racionais e imediatas, nem um processo restrito aos contextos institucionais formais nos quais os autores se enfrentam face a face; mais que isto, ela se configura como processo de aprendizagem que se estabelece de forma reflexiva e que deve auxiliar os cidadãos a melhor compreender determinados problemas de interesse coletivo - como a Corrupção, suas causas e efeitos. Assim, em vários casos, a deliberação é o resultado da atualização constante dos debates políticos que acontecem em esferas públicas parciais, de maneira a alimentar práticas de intercompreensão, cujo objetivo é a constituição de locus de diagnósticos, análises e prognósticos das questões que interessam à população.

\footnotetext{
${ }^{21}$ Aprofundamos esta discussão no meu texto Leal, Estado, Administração Pública e Sociedade: novos paradigmas.

22 Ver o texto de Jürgen Habermas, On the pragmatics of social interaction (Cambridge: MIT, 2002), 23 e ss. Vai nesta direção também os textos de: H. George Fredrickson, “Toward a New Public Administration”, in Classics of Public Administration, ed. Jay MS e Albert CH Eds (4. ${ }^{a}$ ed., San Diego: Harcourt, 1997), 329-341; Fredrickson, The Spirit of Public Administration (San Francisco, CA: Jossey-Bass, 1997); Fredrickson, "Public Administration in the 1970s: Developments and Directions", Public Administration Review 36, 5 Special Bicentennial Issue: American Public Administration in Three Centuries (1971): 564-576; Fredrickson, "The Lineage of New Public Administration", Administration \& Society 8, 3 (1976): 149-174; Fredrickson, "Comparing the Reinventing Government Movement with the New Public Administration", Public Administration Review 56, 3 (1996): 263-270; Fredrickson, "Public Perceptions of Ethics in Government: The Problems of Distance and Role Differentiation", The Annals of the American Academy of Political and Social Sciences (primavera, 1995).
} 
A forma de gestão pública comunicativa de que estamos falando exige um mínimo de condições subjetivas e objetivas dos seus interlocutores, para que possam atingir o que chamamos anteriormente de posturas cognitivas e comunicativas coerenciais, sob pena das falas enunciadas e trocadas serem coatadas por circunstâncias exógenas e endógenas à comunicação, tais como as insuficiências formativas e de discernimento dos homens comuns do povo, associada com o alto grau de profissionalismo e burocratismo das elites dominantes que assaltam cotidianamente o Estado, ou, ainda, dos tecnoburocratas que instrumentalizaram ideológica e operacionalmente os aparelhos estatais, como mecanismo de alcançar projetos muito mais privados do que comunitários, não raro envolvidos em esquemas corruptivos os mais sofisticados.

Onde se fizer ausente a capacidade de manifestação da vontade do cidadão como artífice de sua própria história, em face de insipiência política e administrativa, material e subjetiva, falecendo-lhe forças e perspetivas sobre os termos e possibilidades de gestão que circunvizinha seu cotidiano, só se reforça a situação de anomia societal no âmbito do poder institucionalizado e de seu exercício, em todas as suas dimensões (legislativa, executiva e jurisdicional), fortificando, por ato reflexo ou convexo, a situação confortante dos encastelados nas hordas da máquina estatal, que continuarão a corromper o sistema social, político e econômico, nacional e globalmente.

Decorrência disto é que, mesmo naquelas circunstâncias em que há previsão formal de participação política, ela não é exercitada material e eficazmente por estar marcada pela manipulação e esvaziamento provocado pela ausência daquelas condições mínimas necessárias à comunicação e entendimento.

Por tais razões, não se mostra suficiente tão-somente criar novos espaços públicos à deliberação, nos quais os participantes possam restaurar a amplitude da esfera pública e fazê-la mais inclusiva, sempre atentos às armadilhas da racionalidade estratégica e instrumental que informam comportamentos pragmáticos de alguns segmentos do poder, criando núcleos enclausurados de expedientes, rotinas e prerrogativas excludentes de quaisquer neófitos que pretendam se aproximar dos temas cujas competências já estão dimensionadas pela ordem jurídica e política vigente, afastando todo aquele que não reza pela mesma cartilha ou não é iniciado no 
universo linguístico que lhes é próprio - ensejando a absoluta falta de controle social do exercício do poder político, o que fomenta o incremento de atos corruptivos.

E não se venha trazer o argumento de que a complexidade da Administração Pública dificulta a participação social, isto é retórica ideológica, fundada, primeiro, na ideia de que o tema da Administração Pública possui um grau de complexidade e especificidade que vão desde sua dimensão gramatical/linguística à sua operacionalização, eis que conta com universo categorial tão próprio e pontual que só é alcançado pelos já iniciados em sua ciência, deixando os incautos cidadãos comuns do povo sem compreensão sígnica dos seus enunciados e discursos, o que inviabiliza, por consequência, a compreensão de suas práticas, eis que decorrência da operacionalização daqueles conceitos e discursos. Em tal cenário, o que resta à sociedade é, tão-somente, avaliar os resultados das ações e políticas públicas, sendolhe vedado o alcance dos níveis de discussão e deliberação sobre a conceção/eleição daquelas ações e políticas - onde muitas vezes se encontram atos ilícitos e corruptivos fantasiados de perfeição formal ${ }^{23}$.

O problema é que estas teses partem de pressupostos equivocados e ultrapassados, quais sejam, os de que somente os mecanismos e instrumentos da Democracia representativa (voto, partidos políticos, parlamento, etc.) é que têm a competência e legitimidade exclusiva à representação dos interesses sociais; o fato de que a sociedade civil contemporânea não consegue se articular/mobilizar em torno de suas demandas, a ponto de veicular propostas, ações e cobranças eficazes em termos de gestão da coisa pública o combate a Corrupção.

É possível a superação destes paradigmas a partir das premissas que levantamos aqui.

\footnotetext{
${ }^{23}$ Ver a título exemplificativo o texto de Michelangelo Bovero, Una grammatica della democrazia (Millano: Trotta, 2002), 137 e ss.
} 



\title{
A Razão Pública por trás do constitucionalismo internormativo da União de Direito*
}

\author{
Sergio Maia Tavares Marques**
}

RESUMO: O presente texto identifica os valores fundantes da atuação politica da União Europeia (UE) que orientam o funcionamento desta polity que se materializa por meio da União de direito. Para tanto, épressuposto o conceito de razãa pública como parâmetro da organização pública e regulatória da União sobre os propósitos com os quais está comprometida por força do seu sistema jurídico. Tal ordenamento está baseado na teoria de interconstitucionalidade e, portanto, este ensaio pretende descrever e vincular os sentidos dos fundamentos juridico-valorativos que estruturam o constitucionalismo internormativo da União.

PALAVRAS-CHAVE: união de direito - interconstitucionalidade - razão pública - interjusfundamentalidade.

ABSTRACT: This paper identifies the foundational values of the political action of the European Union (EU) that guide the functioning of the polity materialised through the idea of a Union based on the rule of law. To this effect, the concept of public reason is presupposed as parameter of the public and regulatory organisation of the Union over the purposes to which it is committed by virtue of its legal system. Such system is based on the theory of interconstitutionality and thus this essay intends to describe and bind the senses of the legal-value foundations which structure the inter-normative constitutionalism of the Union.

KEYWORDS: union based on the rule of law - interconstitutionality - public reason - interjusfundamentality.

\footnotetext{
* O presente texto resulta das investigações em curso do autor no âmbito do Centro de Estudos em Direito da União Europeia - CEDU que integram a agenda de pesquisa, o projeto de dissertação e cujas reflexões estarão presentes na versão final da mesma, servindo o presente para abrir o debate e proporcionar críticas para o seu seguimento e aprimoramento.

${ }_{* *}^{*}$ Mestrando em Direito da União Europeia pela Universidade do Minho. Membro não Doutorado do Centro de Estudos em Direito da União Europeia - CEDU e Managing Editor de UNIO - EU Law Journal.
} 
A compreensão teórica da União Europeia no seu diapasão jurídico-político tem despertado inúmeras teses e proposições de distintas escolas de pensamento, dos neofuncionalistas ${ }^{1}$ aos federalistas ${ }^{2}$, do internacionalismo juspublicista clássico das organizações internacionais ${ }^{3}$ aos pluralistas $^{4}$ e internormativos ${ }^{5}$. É ainda certo que dentro dessas escolas há diferentes tendências e campos de estudo com características ontológicas, metodológicas e epistemológicas próprias ${ }^{6}$.

Contudo, tanto no plano normativo como no plano positivo é precisamente a internormatividade pluralista a corrente teórica que mais prosperou e que reconhecidamente é aquela capaz de melhor descrever, explicar, justificar e aplicar a integração europeia como factualidade e como força sócio-jurídico-normativa.

Conquanto a interjusfundamentalidade, a internormatividade e a interjurisdicionalidade associadas ao constitucionalismo plural dão o mote ao debate, o objeto deste breve ensaio não é fazer um exercício comparatista entre as referidas correntes de pensamento nem aprofundar os meandros teóricos da pujante escola ${ }^{7}$.

\footnotetext{
1 Para uma visão geral dessa corrente, capitaneada originariamente por Ernet Haas, ver: "The neofunctionalists were (almost) right: politicization and European integration”, Lisbet Hooghe e Gary Marks, acesso em julho 27, 2017, https://www.wiso.uni-hamburg.de/fachbereich-sowi/professuren/ wiener/dokumente/conwebpaperspdfs/2005/conweb-5-2005.pdf.

${ }^{2}$ Ver como “tipo ideal”, por todos, Dusan. Sidjanski, O futuro federalista da Europa (Lisboa: Gradiva, 1996) e Dusan Sidjanski, Para um federalismo europeu. (Cascais: Principia, 2001).

${ }^{3}$ Ver: Maria Luísa Duarte, Estudos sobre o Tratado de Lisboa. (Coimbra: Almedina, 2010) e Maria Luísa Duarte "O Direito da União Europeia e o Direito Europeu dos Direitos do Homem - uma defesa do "triângulo judicial europeu", in: Estudos em Homenagem ao Prof. Doutor Armando M. Marques Guedes, coord. Jorge Miranda (Coimbra: Coimbra Editora, 2004), 735-772.

${ }^{4}$ Ver, por todos: Miguel Poiares Maduro, A Constituição plural. Constitucionalismo e União Europeia. (Cascais: Principia, 2006).

${ }^{5}$ Ver, por todos:José Joaquim Gomes Canotilho, Brancosos e interconstitucionalidade. Itinerários dos discursos sobre a historicidade constitucional. (Coimbra: Almedina, 2012), Alessandra Silveira, "Do âmbito de aplicação da Carta dos Direitos Fundamentais da União Europeia: recai ou não recai? - eis a questão!”, Revista Julgar 22 (JaneiroAbril 2014) e Alessandra Silveira, "Intersubjectividade, interdemocraticidade, interconstitucionalidade", in: Pensar radicalmente - estudos em homenagem ao Professor Doutor Acílio da Silva Estanqueiro Rocha, org. João Cardoso Rosas e Vitor Moura (Braga:Edições Húmus, 2012).

${ }^{6}$ Ver, exemplificativamente, Matej Avbelj e Jan Komárek, Constitutional Pluralism in the European Union and Beyond (Oxford: Hart, 2012).

${ }^{7}$ Que podem ser encontrados, por exemplo, em: 'Four visions of Constitutional Pluralism”, Matej Avbelj e Jan Komárek, acesso em julho 27, 2017, http://cadmus.eui.eu/bitstream/handle/1814/9372/ LAW_2008_21.pdf?sequence=1\&isAllowed=y. E que também passa por reflexões críticas, como "case and the demise of the pluralist movement", Daniel Sarmiento, acesso em julho 27, 2017, https://
} 
Em verdade, o intuito é refletir acerca da existência e configuração de uma razão pública que move a União Europeia como União de Direito, na natureza jurídica que o Tribunal de Justiça lhe reconheceu no acórdão Os Verdes ${ }^{8}$, que se funda na interconstitucionalidade/constitucionalismo plural. Por isso, essa contextualização teorética é relevante como pressuposto da presente exposição. Assim, é preciso perceber que assumimos tal caracterização do poder político-constitucional da União Europeia para, por consequência, apreciá-la na qualidade de União de Direito e, finalmente, explorar a sua razão pública subjacente - que é o que se pretende por ora.

Com efeito, neste enquadramento, interessa rememorar panoramicamente a evolução histórica da ideia de Razão Pública, desde a Razão de Estado passando pelo Estado de direito. Naturalmente, o presente escrito não se posiciona como um exercício de história das ideias, mas, em se tratando de um percurso de séculos, é preciso respeitar a historiografia à volta do tema e reconhecer que terá meramente lugar, para este efeito, uma enumeração ilustrativa dos conceitos.

A institucionalização de um agir público aparece a partir do Renascimento tardio europeu com a categoria de razão de Estado ou, mais precisamente, ragione di stato italiana e raison d'etat francesa para aludir ao exercício do poder soberano. Foi Francesco Guicciardini o pioneiro da conceptualização, tendo promovido a mesma para exaltar as qualidades do governo dos Antigos ${ }^{9}$ e que, para ele, refletiam-se nos valores do publicismo veneziano de então. Designadamente, hierarquizada arquitetura institucional veneziana, com a autoridade monárquica do Doge, a aristocracia do Senado e a democracia do Conselho Grande ${ }^{10}$.

Quem consagrou a expressão, no entanto, foi Giovanni Botero, defendendo que a finalidade do agir público é conservar o poder, com base na prudência, pois

\footnotetext{
despiteourdifferencesblog.wordpress.com/2015/09/21/the-omt-case-and-the-demise-of-the-pluralistmovement/.

8 Acórdão TJUE de 23 de abril de 1986, Os Verdes, Processo 294/83, ECLI:EU:C:1986:166, considerando 23.

9 Felipe Charbel Teixeira "A República bem ordenada: Francesco Guicciardini e a arte do "bom governo"”' (Master's diss., Pontifícia Universidade Católica do Rio de Janeiro, 2004).

${ }^{10}$ Dawisson Belém Lopes, "Da Razão de Estado ao Republicanismo Mitigado: Uma Narrativa Faoriana sobre a Produção da Politica Externa Brasileira”, Revista de Ciências Sociais 57,2 (2014).
} 
"Stato è un dominio fermo sopra popoli e ragione di Stato si è notizia di mezzi a fondare, conservare e ampliare un dominio. Egli è vero che, sebbene assolutamente parlando, ella si stende tre parti sudette, nondimeno pare che più strettamente abbracci la conservazione che l'altre, e dell'altre più l'ampliazione che la fondazione"'11.

Todavia, é Nicolau Maquiavel, mesmo sem se valer textualmente da expressão, que promove o definitivo enriquecimento ontológico e epistemológico da categoria (método de governar). O ponto comum da autonomização racional do agir político torna-se claro. Muito mais interessante do que o debate sobre a amoralidade na sua obra é a afirmação de que o poder político público não obedece a uma norma, senão aquela que ele próprio decide seguir. Não está, assim, subordinado. Foi a rutura do Estado com a antiga cosmovisão natural da moral religiosa, cujas estruturas organizacionais passaram a instrumento do exercício do então chamado poder soberano da pessoa ocupante da autoridade chefe dos negócios oficiais.

A razão de Estado estava a serviço do equilíbrio e da procura de poder ${ }^{12}$. Mais do que uma moral própria, o poder público é ungido com a sua própria ética. Nenhuma pré-conceção orientaria a priori a ação política. Foi essa formulação da racionalidade eminentemente política, nascida no contexto específico de necessidades da Contrarreforma italiana ${ }^{13 / 14}$ que permitiu ao Estado moderno ${ }^{15}$ prosperar.

É nesse sentido que deve ser interpretada a substância republicana de então de que "não é o bem particular, mas o bem comum que faz a grandeza das cidades" 16.

De outra banda, o Cardeal Richelieu usou a "raison d'etat" para escusar qualquer tipo de constituição como limite à sobrevivência do poder do Estado centralizador. Em concreto, aplicou o conceito para distanciar a França da influência dos cânones

\footnotetext{
${ }^{11}$ Giovanni Botero, Della Ragione di Stato (Roma: Donzelli Editore, 1997).

${ }^{12}$ Maurizio Viroli, "Machiavelli and the republican idea of politics", in Machiavelli and republicanism, eds. Gisela Bock, Quentin Skinner e Maurizio Viroli (Cambridge: CUP, 1990).

${ }^{13}$ Para Adam Watson, a razão de Estado na altura era um "cálculo de praticidade". Cfr. Adam Watson, Evolução da sociedade internacional (Brasília: UnB, 2002).

${ }_{14}$ M. García Pelayo, "Estudio preliminar", in La razón de Estado y otros escritos, ed. Giovanni Botero (Caracas: Livraria dos Advogados Editora, 1962).

${ }^{15}$ Conforme Max Weber e os elementos com que o caracterizou em: Max Weber, A Política como vocação. (Brasília: UNB, 2003).

${ }^{16}$ Niccolò Machiavelli, Oeuvres (Paris: Editions Robert Laffont, 1998).
} 
católicos (do Sacro Império Romano), em meio à ascensão protestantista na Europa, e atuar na política externa contra o Império Habsburgo com vistas a preservar a integridade do Estado nacional francês católico. Assim, associada aos protestantes, acabou até por, na última fase da Guerra dos Trinta Anos, ir à guerra contra a Espanha.

O posicionamento político francês, sob a liderança de Richelieu, é um lapidado exemplo de concretização da razão de Estado clássica, do agir público conforme a contingência que rodeia em defesa da conservação do poder político. Segundo Joseph Bergin,

"Richelieu não pensou em termos de ganhos territoriais massivos, e muito menos nas fronteiras "naturais" da França. Ele buscava obter e manter as passagens entre a França e seus viz̧inhos, e o fez em uma perspectiva essencialmente defensiva. (...) Richelieu buscava uma paz durável e geral na Europa, fundada num sistema de preferência à segurança coletiva acima das alianças clássicas" 17.

Nesse sentido, é a Paz de Westphalia que encerra esse capítulo e funda um novo regime na ordem internacional, que, em última análise, só será superado completamente com os albores da União Europeia e da incipiente força extra-estatal do regionalismo pós-Guerra Fria ${ }^{18}$.

Dessarte, a emergência do Estado de Direito contrapõe-se à razão de Estado, segundo porventura a totalidade dos autores ${ }^{19}$. Na forma do rule of law ${ }^{20}$, os poderes públicos ficam vinculados à conformidade ante ao sistema jurídico vigente, isto é, uma adequação às previsões normativas validamente produzidas à luz dos direitos individuais. Os referidos valores regulatórios e participativos ${ }^{21}$, além da tutela jurisdicional efetiva e da boa administração, foram reunidos sob o signo de direitos fundamentais e de cidadania e só foram progressivamente sendo consagrados em definitivo depois do fim da II Guerra Mundial, séculos mais tarde.

Em última análise, a razão de Estado validava qualquer agir político. De uma

\footnotetext{
${ }^{17}$ Joseph Bergin, Three faces of Richelieu: a historiographical essay (Oxford: Oxford University Press, 2009).

${ }^{18}$ Andrew Hurrell, "O ressurgimento do regionalismo na política mundial", Contexto Internacional 17,1 (1995).

${ }^{19}$ Ver, por todos, Eusebio Fernández García. Entre la razón de Estado y el Estado de derecho: la racionalidad politica (Madrid: Dynkinson, 1997).

${ }^{20}$ Melhor teorizado em Ronald Dworkin, Law's empire. (Cambridge: HUP, 1988).

${ }^{21}$ Formadores, para Pierre Rosanvallon, de "le bon gouvernement". Sugerimos: Pierre Rosanvallon, El buen governo (Buenos Aires: Manatial, 2015).
} 
forma ou de outra, pela conceção de uma escola de pensamento ou outra, a razão de Estado clássica sempre opôs direitos do cidadão à discricionariedade/arbitrariedade 22 do poder público e levou ao cometimento de atos políticos atrozes e insustentáveis. Da razão de Estado resulta o benefício de um e o prejuízo do Outro ${ }^{23}$ (de todos os demais). Simplesmente não esteve na sua pauta o valor da vontade democrática (participação política e controlo de accountability) pelos povos.

Ao revés, na forma do Rechtsstaat, a polity só pode existir validamente se for a democracia (bem entendida aqui como os valores extraídos dos direitos fundamentais) a instituir a sua ordem jurídica, ou seja, supõe a relação intrínseca entre democracia e direito. Os dois valores inicialmente mais intensos eram os de liberdade e propriedade, que ao longo do século XX foram depurados por óbvias razões, hauriram o controlo jurisdicional dos atos da Administração, que passou a estar, ela mesma, submetida em primeiro lugar. Como conhecido, o Bundesverfassungsgericht foi ampliando o escopo de proteção dos direitos fundamentais na sua magistratura jurisprudencial.

Em síntese, todas as fórmulas que constitucionalizaram e democratizaram o Estado de direito buscam superar o critério da manutenção e ampliação do poder pelo poder e aplicar o critério da obediência à normatividade pela atuação pública/ agir político, isto é, da juridicidade.

No atual contexto de desenvolvimento da rede de interconstitucionalidade ${ }^{24}$, que delineia a atual etapa da atividade pública regulatória, é indispensável localizar e posicionar devidamente o poder político da União Europeia.

A fundação da UE como polity foi a priori de natureza jurídica e não política, no sentido de que não derivou ${ }^{25}$ de um demos comum, da identidade de um povo europeu, senão antes afirmou a assimilação da coletividade cosmopolita dos povos europeus ${ }^{26}$.

\footnotetext{
${ }^{22}$ De resto, confronto essencial que resume a querela teórica entre Hans Kelsen e Carl Schmitt.

${ }^{23}$ No sentido firmado por Hans-Georg Gadamer. Ver, por todos, H.-G. Gadamer, Verdade e método: traços fundamentais de uma bermenêutica filosófica (Petrópolis: Vozes, 1997).

24 “É precisamente a União Europeia que (...) torna arcaico o esquema conceitual do Estado que se revela incapaz de fornecer compreensões juridicamente adequadas aos problemas de um novo fenótipo organizativo" José Joaquim Gomes Canotilho, Brancosos, 231.

${ }^{25}$ Sendo certo que o fenómeno jurídico está contido no fenómeno político.

26 "European democracy and its critique - five uneasy pieces", Joseph Weiler, Ulrich Haltern e Franz
} 
Ora, foi preciso assim construir uma democracia supranacional com os elementos constitutivos de uma polity pela via jurídica da integração e do constitucionalismo plural ${ }^{27}$.

Na governação da UE contemporânea, que revolucionou o papel do Estado pela articulação das esferas de poder, a razão público-política obedece à normatividade jurídica ou, em diálogo com Konrad Hesse, à força normativa da “Wille zur verfassung”. Eis a viragem vanguardista. Graças à integração europeia, a política do século XXI só é legítima se exercida dentro da moldura do quadro que acolhe a pintura do Direito para além do Estado.

Por esse motivo, a razãa pública da União de Direito de agora não é apenas um silogístico passo à frente em relação ao Estado de Direito. É uma figura típica, o somatório resultante da adição entre os critérios formal (juridicidade) e material (efetividade dos valores dos direitos fundamentais e de cidadania positivados na Carta dos Direitos Fundamentais), pelo que o sistema jurídico exerce uma espécie substancialmente democratizada e contramajoritária de Poder Moderador ${ }^{28}$, em que o direito (das garantias fundamentais não pode ser reduzido - daí o princípio do nível de proteção mais elevado!) precede o agir político. A pré-compreensão do agir político pode até ser racionalmente política, porém há sempre de subsumir-se aos valores materiais do direito que lhe ultrapassam, de modo que aquele nunca poderá ser antijurídico. Cuida-se, pois, de uma inovação da integração destes nossos tempos.

Com efeito, resta responder ao cerne de quais são esses valores jurídicos substanciais por trás da atual razão pública da União de direito. É dizer, qual é o regime que orienta, e deve orientar, o agir político da UE, equilibrado entre a compleição federalista e o constitucionalismo plural.

Sem dúvida, os valores jurídicos subjacentes, fundantes e parametrizadores do agir e do poder político (polity) da União de Direito materialmente considerada são os direitos fundamentais e de cidadania expressados na Carta dos Direitos Fundamentais

\footnotetext{
Mayer, acesso em julho 27, 2017, http://cadmus.eui.eu/bitstream/handle/1814/1386/95_11.pdf.

${ }^{27}$ Miguel Poiares Maduro, A Constituição.

${ }^{28}$ Christian Edward Cyril Lynch, "O momento monarquiano: o Poder Moderador e o pensamento político imperial” (PhD diss., IUPERJ, 2007).
} 
da UE, além dos seus princípios ${ }^{29}$ inerentes, instrumentais e acessórios.

Nessa matéria, Alessandra Silveira pontifica três momentos da cidadania da União que explicam a sua relação com os direitos fundamentais: uma cidadania de mercado exemplificada no Regulamento 1612/68 e nos acórdãos Walrave e Koch ${ }^{30}$ e acórdão Lawrie-Blum ${ }^{31}$; uma cidadania social a partir do acórdão Martínez Sala ${ }^{32}$; e, finalmente, a partir do acórdão Zambrano ${ }^{33}$ e do acórdão Rottman (em especial as Conclusões Fundamentadas do Advogado Geral Miguel Poiares Maduro) ${ }^{34}$, uma cidadania de direitos/republicana ${ }^{35}$. Esse decurso de autonomização da cidadania face aos Estados-Membros e de intrinsecidade ${ }^{36}$ com os direitos fundamentais conforma o que já denominamos de cidadania terroir ${ }^{37}$.

Ora, a essa cidadania corresponde, entre outros, o funcionamento da economia social de mercado (no mercado interno) que "tenha como meta o pleno emprego e o progresso social (...)", na redação do artigo 3. ${ }^{\circ}$, n. 3, Tratado da União Europeia; e os direitos sociais que combatam a exclusão e garantam proteção, igualdade, não-discriminação e a coesão.

\footnotetext{
${ }^{29}$ Como o nível de proteção mais elevado, da autonomia do direito da União, da equivalência e efetividade, do efeito direito, da preferência aplicativa, da autonomia processual, da responsabilidade, da interpretação conforme, tutela jurisdicional efetiva, da não discriminação, da lealdade, etc.

${ }^{30}$ Acórdão TJUE de 12 de dezembro de 1974, Walrave e Koch, Processo 36/74, ECLI:EU:C:1974:140.

31 Acórdão TJUE de 3 de julho de 1986, Lawrie-Blum, Processo 66/85, ECLI:EU:C:1986:284.

32 Acórdão TJUE de 12 de maio de 1998, Martínez Sala, Processo C-85/96, ECLI:EU:C:1998:217.

33 Acórdão TJUE de 8 de março de 2011, Zambrano, Processo C-34/09, ECLI:EU:C:2011:124.

${ }^{34}$ Acórdão TJUE de 2 de março de 2010, Rottman, Processo C-135/08, ECLI:EU:C:2010:104.

35 Alessandra Silveira, "Cidadania Europeia e Direitos Fundamentais", in Direito da União Europeia Elementos de Direito e Políticas da União (Coimbra: Almedina, 2016).

36 “(...) Mais que um estatuto numa perspectiva estática, a cidadania europeia pode ser percecionada enquanto um processo de dimensão jurídico-constitucional (...) não foi por outra razão que o debate em torno da cidadania europeia se desenvolveu paralelamente (e acabou por confundir-se com) àquele da proteção dos direitos fundamentais no âmbito da União: se os cidadãos europeus são titulares de direitos previstos nos Tratados (o que resulta hoje plasmado no art. 20. ${ }^{\circ}$, n. ${ }^{\circ}$, do TFUE), são-no também (e sobretudo) titulares dos direitos fundamentais reconhecidos pela ordem jurídica europeia - quer exerçam liberdades económicas, quer não as exerçam. Ser cidadão europeu significa basicamente ser titular de direitos protegidos pela ordem jurídica europeia máxime direitos fundamentais" Cfr. Alessandra Silveira, "Cidadania Europeia", 24.

${ }^{37}$ Por oposição à "cidadania pacha". Para mais Sergio Maia Tavares, "Cidadania pacha, cidadania terroir: notas comparadas sobre o cidadão na União Europeia, no Mercosul e o Direito da Integração no Novo Constitucionalismo Latino-Americano", in O Direito Internacional Privado Atual e Outros Temas Contemporâneos: Festschrift ao Professor Jacob Dolinger, org. Carmen Tiburcio, Wagner Menezes e Raphael Carvalho de Vasconcelos (Belo Horizonte: Arraes, 2015).
} 
O agir político da União, especialmente por obra do Tribunal de Justiça da União Europeia, abraça essa raz̃ão pública materialmente considerada, vinculando em tese todas as instituições e Estados-Membros quando apliquem o direito da União. Logo, qualquer ato da governação plural da integração tem que observar tais preceitos para ser legítimo politicamente e válido juridicamente. 



\title{
Em busca de um sentido de pertença à comunidade nascida da integração por via do estatuto de cidadão da União - de Rottmann a Petrubhin
}

\author{
Sophie Perez Fernandes*
}

RESUMO: A cidadania da União instituida em Maastricht consubstancia seguramente uma das construções mais significativas do processo de integração europeia. Procurando aprofundar o processo de integração europeia, a cidadania da União tem vindo a proporcionar, num espaço comum (cada vez) mais alargado, um estatuto reforçado de proteção dos nacionais dos Estados-Membros enquanto cidadãos da União e neles fomentar valores de igualdade, pertença e identidade coletiva. O presente texto visa refletir sobre cidadania da União como instituto potenciador da emergência de uma comunidade política europeia. Para o efeito, considera especialmente dois acórdãos do Tribunal de Justiça, o acórdão Rottmann e o acórdão Petrubbin, no sentido de demonstrar de que forma a mobilização concorrente e construtiva das ordens jurídicas da União e dos Estados-Membros opera para a resolução de problemas atinentes ao estatuto jurídico de cidadão da União.

PALAVRAS-CHAVE: Cidadania da União - comunidade política - direitos fundamentais - processo de integração europeia.

ABSTRACT: EU citizenship established in Maastricht is certainly one of the most significant constructions of the European integration process. In seeking to deepen the process of European integration, EU citizenship has provided, within an increasingly wider common space, an enbanced status of protection for nationals of the Member States as citizens of the Union and aims at fostering in them values of equality, belonging and collective identity. The purpose of this text is to reflect on EU citizenship as an institution that promotes the emergence of a European political community. To that end, two judgments of the European Court of Justice are particularly considered, the Rottmann judgment and the Petrubbin judgment, in order to demonstrate how the constructive mobilization of both the EU and the Member States' legal systems operates to solve problems regarding the legal status of citizen of the Union.

KEYWORDS: EU Citizenship - political community - fundamental rights - European integration process.

\footnotetext{
* Professora da Escola de Direito da Universidade do Minho. Membro Doutorado do Centro de Estudos em Direito da União Europeia - CEDU.
} 


\section{Considerações introdutórias}

Tendo o Tratado de Maastricht entrado em vigor a 1 de novembro de 1993, no passado dia 1 de novembro, a cidadania da União completou, discretamente, 24 anos de existência. A cidadania da União instituída em Maastricht consubstancia seguramente uma das construções mais significativas do processo de integração europeia.

Propôs-se desde a sua origem ser uma nova etapa do processo de integração europeia, um momento não só simbólico, mas principalmente de aprofundamento (que não de rutura!) em direção a um modelo de integração para além do paradigma do mercado interno que assumisse plenamente a dimensão política desde a origem inscrita no desenho europeu. A cidadania da União almeja, pois, alicerçar uma etapa do processo de integração europeia pautada por um paradigma político-constitucional assumido enquanto tal - no sentido de ultrapassar (sem abandonar) o paradigma económico-(para o)político inicial ${ }^{1}$ - e de carrear em si o gérmen de uma identidade europeia através do reconhecimento de um estatuto que seja comum (ignaldade) a todos os nacionais dos Estados-Membros e da promoção da sua participação enquanto cidadãos da União tendente a reforçar a legitimidade do processo de integração ${ }^{2}$.

A cidadania da União procura, pois, oferecer os alicerces para o processo de construção de uma comunidade política europeia - de uma comunidade política emergente do processo de integração europeia. A via seguida para o efeito não se afasta daquela a que a construção jurídica da empresa europeia habituou: o reforço da posição do indivíduo

\footnotetext{
${ }^{1}$ Cfr. Ferdinand Wollenschläger, "A New Fundamental Freedom beyond Market Integration: Union Citizenship and its Dynamics for Shifting the Economic Paradigm of European Integration", European Law Journal 17, 1 (2011): 1-34, doi: 10.1111/j.1468-0386.2010.00536.x.; e, entre nós, Pedro Madeira Froufe e José Caramelo Gomes, "Mercado Interno e Concorrência”, Direito da União Europeia - Elementos de Direito e Políticas da União, coord. Alessandra Silveira, Mariana Canotilho e Pedro Madeira Froufe (Coimbra: Almedina, 2016), 449-461.

${ }^{2}$ O objetivo foi assumido expressamente pela Comissão Europeia: "A cidadania da União é simultaneamente fonte de legitimação do processo de integração europeia, devido ao reforço da participação dos cidadãos, e um elemento fundamental para a criação de um sentimento de pertença dos cidadãos à União Europeia, de uma verdadeira identidade europeia." - Comissão Europeia, Terceiro Relatório sobre a cidadania da União, de 07.09.2001, COM(2001) 506 final, p. 7.
} 
num espaço comum (cada vez) mais alargado e, assim, uma abordagem centrada na pessoa e nos seus direitos, com especial destaque hoje, em razão da Carta dos Direitos Fundamentais da União Europeia (CDFUE), para a proteção dos direitos fundamentais - o paradigma de uma cidadania de direitos ${ }^{3}$. A metódica seguida também não é estranha: é a metódica própria do modelo jurídico da integração - o paradigma da internormatividade compreendida como interação reflexiva de normas jurídicas que convivem no espaço jurídico-político da União, do entrelaçamento de centros/níveis decisórios e de ordenamentos jurídicos no tratamento de questões comuns ${ }^{4}$, quais sejam, as questões relativas ao estatuto (jurídico) dos cidadãos da União enquanto sujeitos do processo de integração e membros da comunidade política europeia em emergência.

É neste contexto de proteção de direitos seguindo uma metódica internormativa que nos propomos trazer para debate algumas reflexões em torno da cidadania da União como instituto potenciador da emergência de uma comunidade política europeia. Propomo-nos, para tal, e tendo por base alguns conceitos-chave conhecidos (ainda que pontualmente controvertidos) do discurso da cidadania em termos gerais, como os conceitos de povo, território, soberania, igualdade, pertença e identidade, dar conta do modo como os mesmos são reequacionados no quadro específico e particular da cidadania da União, recorrendo para o efeito a acórdãos do Tribunal de Justiça.

\footnotetext{
${ }^{3}$ Neste sentido, cfr. Alessandra Silveira, "Cidadania e Jusfundamentalidade na União Europeia - do argumento de James Madison à jurisprudência Ruiz, Zambrano", in Estudos em Homenagem ao Prof. Doutor José Joaquim Gomes Canotilho, Volume III - Direitos e Interconstitucionalidade: entre Dignidade e Cosmopolitismo, org. Fernando Alves Correia, Jónatas E. M. Marchado e João Carlos Loureiro (Coimbra: Coimbra Editora, 2012), 939-973.

${ }^{4}$ Sobre a teorização constitucional do processo de integração europeia segundo uma metódica de internormatividade e, em especial, de interconstitucionalidade, cfr., entre nós, Francisco Lucas Pires, Introdução ao Direito Constitucional Europeu (Seu Sentido, Problemas e Limites) (Coimbra: Almedina, 1997); José Joaquim Gomes Canotilho, "Brancosos" e Interconstitucionalidade. Itinerários dos discursos sobre a bistoricidade constitucional (Coimbra: Almedina, 2006); Miguel Poiares Maduro, A Constituição Plural. Constitucionalismo e União Europeia (Cascais: Principia, 2006); Maria Luísa Duarte, União Europeia e Direitos Fundamentais - no espaço da internormatividade (Lisboa: AAFDL, 2006); Paulo Rangel, O Estado do Estado. Ensaios de politica constitucional sobre justiça e democracia (Dom Quixote, 2009); Alessandra Silveira, "Da interconstitucionalidade na União Europeia (ou do esbatimento de fronteiras entre ordens jurídicas”, Scientia Ivridica 326 (2011): 211-223.
} 


\section{A comunidade política europeia emergente da cidadania da União - os contributos da jurisprudência Rottmann e Petrubhin}

A cidadania da União tem-se revelado laboratório de excelência para testar os limites, as fragilidades, mas também as potencialidades, da interação, nem sempre facilmente palpável, entre a nacionalidade institucionalizada nos moldes (tradicionais) do Estado-Nação e a cidadania construída numa esfera política alargada, intrinsecamente pluralista mas integradora. Assumindo que as implicações de dado estatuto jurídico (inter)normativamente desenhado só consegue alcançar a consciência coletiva na sequência de experiências práticas, propomo-nos trazer à colação dois acórdãos do Tribunal de Justiça que nos permitem demonstrar de que forma a mobilização concorrente e construtiva das ordens jurídicas da União e dos Estados-Membros opera para a resolução de problemas atinentes ao estatuto jurídico de cidadão da União.

O célebre acórdão Rottmann ${ }^{5}$ fornece o primeiro exemplo em relação, repare-se, às normas jurídicas relativas à própria titularidade dos estatutos de nacional de um Estado-Membro e de cidadão da União. O caso bem demonstra que, porque o estatuto de cidadão da União depende ou deriva ${ }^{6}$ da qualidade de nacional de um EstadoMembro (arts. 9. ${ }^{\circ}$ TUE e 20. ${ }^{\circ}$, n. ${ }^{\circ}$ 1, TFUE), a cidadania da União vai cunhando a competência dos Estados-Membros em sede de aquisição e perda das respetivas nacionalidades. No caso, Janko Rottmann, nascido austríaco, perdera a nacionalidade austríaca na sequência da aquisição da nacionalidade alemã. $\mathrm{O}$ modo fraudulento pelo qual obteve esta última motivou a revogação, com eficácia retroativa, do ato de naturalização, sem que tal revogação tivesse sido acompanhada da reaquisição da nacionalidade originária. Colocava-se, pois, a questão de saber se o direito da União se opunha à apatridia daí resultante, com a consequente perda do estatuto de cidadão da União ${ }^{7}$. No acórdão, o Tribunal de Justiça começou por deixar claro que uma

\footnotetext{
${ }^{5}$ Acórdão TJUE de 2 de março de 2010, Rottmann, Processo C-135/08, EU:C:2010:104.

${ }^{6}$ Assim, Dimitry Kochenov, "Ius tractum of many faces: European Citizenship and the difficult relationship between status and rights”, in Columbia Journal of European Law 15, 2 (2009): 169-237.

${ }^{7}$ Em concreto, no decurso do procedimento de naturalização, Janko Rottmann havia deliberadamente ocultado que contra ele corria um processo penal na Áustria - cfr. acórdão Rottmann..., cons. 22-28.
} 
situação suscetível de implicar a perda do estatuto de cidadão da União e dos direitos correspondentes "é abrangida, pela sua própria natureza e pelas suas consequências, pelo direito da União", de modo que, no exercício da sua competência em matéria de nacionalidade, os Estados-Membros devem respeitar o direito da União. ${ }^{8}$ O Tribunal de Justiça alongou-se a propósito, esclarecendo que o respeito devido ao direito da União "não ofende o princípio de direito internacional (...) de que os Estados-Membros são competentes para definir as condições de aquisição e de perda da nacionalidade, mas consagra o princípio de que, quando se trate de cidadãos da União, o exercício dessa competência, na medida em que afecte os direitos conferidos e protegidos pela ordem jurídica da União, como é designadamente o caso de uma decisão de revogação da naturalização (...), é susceptivel de fiscalização jurisdicional à luz do direito da União."

Fica em 2010, ano da prolação do acórdão Rottmann, o que desde 1993, ano da entrada em vigor do Tratado de Maastricht, resultava do direito primário: a competência dos Estados-Membros em matéria de nacionalidade não é impermeável ao direito da União e à cidadania por ele instituída. Uma vez a nacionalidade de um Estado-Membro acarreta, por si só, o estatuto de cidadão da União, ela assume intrinsecamente dimensão europeia. Em outros termos, a cidadania da União é componente integrante da nacionalidade de um Estado-Membro ${ }^{10}$, de modo que uma e outra não podem ser compreendidas separadamente, mas sim em termos de interdependência ${ }^{11}$.

Quanto ao problema concretamente em causa - a situação de apatridia -, ela não é, em si mesma, afastada, nem em geral - pois a aquisição e a perda do estatuto

\footnotetext{
${ }^{8}$ Cfr. acórdão Rottmann..., cons. 39-42 e 45.

${ }^{9}$ Acórdão Rottmann..., cons. 48.

${ }^{10}$ Assim, Dora Kostakopoulou, "European Union Citizenship: Writing the Future", European Law Journal 13, 5 (2007): 631.

${ }^{11}$ Neste sentido, cfr. Dimitry Kochenov, "The essence of EU Citizenship emerging from the last ten years of academic debate: Beyond the cherry blossoms and the moon?", International and Comparative Law Quaterly 62, 1 (2013): 98; Ferdinand Wollenschläger, “A New Fundamental Freedom beyond Market Integration: Union Citizenship and its Dynamics for Shifting the Economic Paradigm of European Integration", European Law Journal 17, 1 (2011): 33-34, doi: 10.1111/j.1468-0386.2010.00536.x; "Citizenship: Contrasting Dynamics at the Interface of Integration and Constitutionalism”, Jo Shaw, acesso em março 14, 2017, http://hdl.handle. net/1814/14396.; e Dora Kostakopoulou, "European Union Citizenship: Writing the Future”, 646.
} 
de cidadão da União depende da aquisição e da perda do estatuto de nacional de um Estado-Membro, o que resta da competência dos Estado-Membros ${ }^{12}$-, nem em concreto - pois, no caso, a revogação do ato de naturalização havia sido motivada pela fraude cometida por Janko Rottmann no decurso do procedimento, motivo legítimo à luz do direito da União mesmo quando acarreta a perda do estatuto de cidadão da União $^{13}$. Contudo, e aqui reside a especial valência do acórdão Rottmann, a possibilidade de apatridia é sujeita a um teste de proporcionalidade "à luz do direito da União" em termos tais que a torna, porventura, menos provável $^{14}$. Embora reconhecendo a legitimidade da revogação da naturalização adquirida fraudulentamente, a "importância que o direito primário atribui ao estatuto de cidadão da União" impõe o exame dessa decisão à luz do princípio da proporcionalidade, considerando, entre outros, as consequências resultantes da decisão para o interessado e para a sua família, bem como a possibilidade de o interessado readquirir a sua nacionalidade originária, in casu a nacionalidade austríaca ${ }^{15}$.

O Tribunal de Justiça confia aos órgãos jurisdicionais nacionais o balanceamento entre, por um lado, o interesse legítimo do Estado-Membro em causa em "proteger a particular relação de solidariedade e de lealdade entre ele próprio e os seus nacionais e a reciprocidade

\footnotetext{
${ }^{12}$ Solução inversa faria com que, como explicou Miguel Poiares Maduro, "o acessório determina[sse] o principal: a manutenção da cidadania da União permitiria exigir a manutenção da nacionalidade de um EstadoMembro" - Conclusões Rottmann, de 30 de setembro de 2009, Processo C-135/08, EU:C:2009:588, cons. 24. Daqui resultaria, na prática, que a cidadania da União se substituísse à cidadania nacional em contravenção do disposto nos arts. 9..$^{\circ}$ TUE e $20 .^{\circ}$, n. ${ }^{\circ} 1$, TFUE.

${ }^{13}$ Cfr. acórdão Rottmann..., cons. 50-54.

${ }^{14}$ Neste sentido, Mario Savino chama a atenção de que o acórdão Rottmann, "if taken seriously by domestic courts", conduz ao decaimento da conceção das decisões administrativas relativas à nacionalidade como "political questions" ou "acts of high administration" e, assim, é suscetível de mudar a natureza do controlo judicial exercido sobre tais decisões. Sujeitando tais decisões a um teste de proporcionalidade, o acórdão Rottmann não só "will lead to a more stringent scrutiny (than in the past) and to a firmer protection of the rule of law", mas também "will provide a higher level of guarantee for the individual in a field - nationality - where state sovereignty has been almost systematically translated in terms of wide administrative discretion" - cfr. Mario Savino, "EU Citizenship: Post-National or Post-Nationalist? Revisiting the Rottmann Case through Administrative Lenses", European Review of Public Law 23, 1 (2011): 42 e 45-46.

${ }^{15}$ Cfr. acórdão Rottmann..., cons. 55-59. Nas suas Conclusões, Miguel Poiares Maduro propôs uma solução assente nas regras de direito nacional aplicáveis e, em particular, na eficácia retroativa da perda da nacionalidade alemã, sem passar por um teste de proporcionalidade - cfr. Conclusões Rottmann, cit., cons. 34 .
} 
dos direitos e deveres, que são o fundamento da relação de nacionalidade", considerando para o efeito, por exemplo, a gravidade da infração cometida, e, por outro, o impacto que a perda do estatuto de cidadão da União, e dos direitos que lhe estão associados, tem para o interessado e a sua família, sendo insistente a respeito da possibilidade de o interessado readquirir a sua nacionalidade originária e, assim, preservar o estatuto de cidadão da União ${ }^{16}$. O Tribunal de Justiça parece sugerir a necessidade de cooperação leal entre os Estados-Membros (de nacionalidade originária e de naturalização) envolvidos, os quais estão, aliás, submetidos ao mesmo parâmetro aquando da tomada das respetivas decisões em matéria de nacionalidade - aquele que resulta do direito da União e do princípio da proporcionalidade tal como delineado no acórdão Rottmann. Com efeito, e muito embora não existisse ainda qualquer decisão tomada a respeito de Janko Rottmann pelas autoridades austríacas, o Tribunal de Justiça não deixou de chamar a atenção para o facto de que os princípios relativos "à competência dos Estados-Membros em matéria de nacionalidade e a obrigação destes de exercerem essa competência no respeito do direito da União se aplicam tanto ao Estado-Membro de naturalização como ao Estado-Membro da nacionalidade de origem”, o que inclui, pois, o princípio da proporcionalidade nos termos desenhados no acórdão ${ }^{17}$.

A atualidade da jurisprudência Rottmann foi recentemente confirmada pelo acórdão Petruhhin ${ }^{18}$. O caso já não se reporta a uma situação de potencial apatridia e consequente perda do estatuto de cidadão da União, mas põe em especial destaque no quadro da cidadania da União dois elementos inscritos no núcleo duro de qualquer discurso em matéria de cidadania: a igualdade dos indivíduos enquanto cidadãos e a sua proteção contra a expulsão do território. Uma das manifestações concretas da ligação intrínseca entre povo, território e poder/soberania no quadro do Estado-Nação é a regra pela qual o Estado não expulsa do seu território os seus nacionais, vigorando, em particular, o princípio da não extradição dos nacionais ${ }^{19}$.

\footnotetext{
${ }^{16}$ Cfr. acórdão Rottmann..., cons. 51 e 56-58.

${ }^{17}$ Cfr. acórdão Rottmann..., cons. 62 e 63.

${ }^{18}$ Acórdão TJUE de 6 de setembro de 2016, Petrubhin, Processo C-182/15, EU:C:2016:630.

${ }^{19}$ Sobre o tema, cfr., entre nós, Miguel João Costa, Dedere aut Judicare? A Decisão de Extraditar ou Julgar à Luz do Direito Português, Europeu e Internacional (Coimbra: Instituto Jurídico da Faculdade de Direito da
} 
Como demonstra o acórdão Petrubhin, e sem que tenha sido posta em causa este princípio, estando em causa um pedido de extradição em relação a um cidadão da União dirigido a um Estado-Membro que não seja o da sua nacionalidade, a cidadania da União proporciona ao indivíduo um estatuto de proteção - da mesma forma que, em Rottmann, o direito da União, via cidadania, enquadrou o exercício da competência dos Estados-Membros em matéria de aquisição e perda da respetiva nacionalidade, em Petrubhin, o direito da União, via cidadania, enquadrou o exercício da competência dos Estados-Membros em matéria de extradição, em ambos os casos reforçando a proteção jurídica associada ao estatuto de cidadão da União.

O caso surge na sequência da apresentação de um pedido de extradição pelas autoridades russas às autoridades letãs relativamente a Aleksei Petruhhin, nacional estónio, relacionado com uma infração por tráfico de estupefacientes. Tendo a Procuradoria-Geral da República da Letónia autorizado a extradição, Aleksei Petruhhin impugnou judicialmente a decisão de extradição. O litígio judicial que se seguiu foi levado até ao Supremo Tribunal da Letónia que decidiu suspender a instância e reenviar ao Tribunal de Justiça a título prejudicial. O órgão jurisdicional de reenvio salienta que nem o direito nacional (letão) nem nenhum dos acordos internacionais celebrados pela República da Letónia, designadamente com a Federação da Rússia, preveem limitações à extradição de um nacional estónio para a Rússia ${ }^{20}$ - ou seja: só os nacionais letões beneficiam da regra que proíbe a extradição. Para o órgão jurisdicional de reenvio, "a falta de proteção dos nacionais da União contra a extradição, quando se deslocaram para um Estado-Membro diferente do da sua nacionalidade, é contrária à essência da cidadania europeia, concretamente ao direito dos cidadãos da União a uma proteção equivalente à dos nacionais." ${ }^{21}$ Pretendia, por isso, saber se as disposições do direito da União em matéria de cidadania da União, especialmente o princípio da não discriminação em razão da nacionalidade (art. 18. ${ }^{\circ}$ TFUE) e o direito à livre circulação e residência (art. $21^{\circ}{ }^{\circ}$, n. ${ }^{\circ}$ 1, TFUE), exigiam que, em caso de extradição

Universidade de Coimbra, 2014); e Nuno Piçarra, “A proibição constitucional de extraditar nacionais em face da União Europeia”, Revista do CEJ 7 (2007): 243-263.

${ }^{20}$ Cfr. acórdão Petrubbin..., cons. 10-15.

${ }^{21}$ Acórdão Petrubhin..., cons. 16. 
[para um Estado terceiro (Rússia)], fosse garantido aos nacionais dos outros EstadosMembros (Estónia) o mesmo nível de proteção que o conferido aos nacionais do Estado-Membro requerido (Letónia). O problema reporta-se, de facto, à "essência da cidadania europeia": o imperativo de igualdade entre os nacionais dos EstadosMembros, especialmente aqueles que exercem o seu direito de livre circulação em residência no território dos Estados-Membros. A questão é a seguinte: o benefício do tratamento nacional que daí resulta para os cidadãos da União estende-se à proteção contra a extradição reservada aos nacionais do Estado-Membro de acolhimento/ requerido?

Antecipando uma resposta negativa, o órgão jurisdicional de reenvio chama à colação a CDFUE e, em especial, o seu art. 19. ${ }^{\circ}$ relativo à proteção em caso de afastamento, expulsão ou extradição. Assim, caso se deva proceder à extradição sem ter em consideração o nível de proteção especial previsto para os nacionais do Estado-Membro requerido, deve, ainda assim, esse Estado-Membro zelar pela observância das garantias previstas no art. 19. ${ }^{\circ}$ CDFUE? O problema reporta-se aqui à proteção dos direitos fundamentais na ordem jurídica da União. A hipótese é a seguinte: não sendo a cidadania da União suficiente para obstaculizar a extradição, poderá, ainda assim, ser suficiente para o efeito a proteção concedida ao abrigo do art. 19. ${ }^{\circ}$ CDFUE contra a extradição para um Estado onde o indivíduo "corra sério risco de ser sujeito a pena de morte, a tortura ou a outros tratos ou penas desumanos ou degradantes"? 22

Em relação à primeira questão, a resposta do Tribunal de Justiça assenta em dois postulados de igual importância que, sem serem mutuamente excludentes, careciam de uma operação de conciliação. A resposta assenta, por um lado, na inexistência de direito da União especificamente aplicável ao problema levantado. Com efeito, na ausência de uma convenção internacional entre a União e o país terceiro em causa (Rússia), as regras em matéria de extradição são da competência dos EstadosMembros ${ }^{23}$. Tal não impede, por outro lado, que $\imath$ ) a situação esteja abrangida pelo

\footnotetext{
${ }^{22}$ Cfr. acórdão Petrubhin..., cons. 17.

${ }^{23}$ Cfr. acórdão Petrubhin..., cons. 26, 30 e 46.
} 
âmbito de aplicação do direito da União e que, em consequência, i̋) os EstadosMembros devam, no exercício daquela competência, respeitar o direito da União, nomeadamente em matéria de cidadania ${ }^{24}$. Se bem que o Tribunal de Justiça não mencione o precedente Rottmann neste particular, a situação de Aleksei Petruhhin está "abrangida, pela sua própria natureza e pelas suas consequências, pelo direito da União" 25 uma vez que se trata de um nacional estónio que, na sua qualidade de cidadão da União, exerceu o seu direito de circular livremente na União para se deslocar para a Letónia ${ }^{26}$. Deste modo, ainda que no exercício de uma competência que permanece sua, este Estado-Membro deve respeitar o direito da União, nomeadamente o princípio da não discriminação em razão da nacionalidade e as disposições em sede de livre circulação e residência dos cidadãos da União ${ }^{27}$. Ora, o direito letão, ao reservar apenas para os nacionais o benefício da proteção contra a extradição, introduz $\imath$ ) uma diferenciação de tratamento fundada na nacionalidade (pois não concede aos nacionais de outros Estados-Membros a proteção contra a extradição de que gozam os nacionais) ii) suscetível de afetar o exercício do direito de livre circulação e residência dos cidadãos da União (pois, mesmo que não a impossibilite ou obstaculize, torna-a menos atrativa $)^{28}$.

Constatada a, a priori, desconformidade com o direito da União do direito letão aplicável, importava, contudo, aferir se a diferenciação de tratamento e consequente restrição ao exercício do direito de livre circulação e residência seria objetivamente justificada e respeitava o princípio da proporcionalidade ${ }^{29}$. No que se refere ao primeiro aspeto, o Tribunal de Justiça considerou legítimo à luz do direito da União o objetivo prosseguido pelo direito letão de evitar o risco de impunidade das pessoas que cometeram uma infração ${ }^{30}$. De outro modo não podia ser, não tivesse a União

\footnotetext{
${ }^{24}$ Cfr. acórdão Petrubbin..., cons. 27, 29 e 30.

${ }^{25}$ Acórdão Rottmann..., cons. 42.

${ }^{26}$ Cfr. acórdão Petrubbin..., cons. 31.

${ }^{27}$ Cfr. Conclusões Petrubbin, de 10 de maio de 2016, Processo C-182/15, EU:C:2016:330, cons. 43.

${ }^{28}$ Cfr. acórdão Petrubbin..., cons. 32-33.

${ }^{29}$ Cfr. acórdão Petrubbin..., cons. 34 e 38.

${ }^{30}$ Nas Conclusões Petrubhin..., cons. 51-55, Yves Bot considera outros fundamentos que sustentam o princípio de não extradição dos nacionais, como o dever de proteção que um Estado-Membro deve
} 
como objetivo (art. 3. ${ }^{\circ}$, n..$^{\circ}$, TUE) o de proporcionar aos seus cidadãos um espaço de liberdade, segurança e justiça sem fronteiras internas, o que inclui, entre outros, medidas adequadas de prevenção e combate da criminalidade ${ }^{31}$. À semelhança do acórdão Rottmann, decisivo foi o teste de proporcionalidade à luz do direito da União.

As regras de direito interno em causa - que apenas permitem responder favoravelmente a um pedido de extradição dirigido a um não nacional - eram, por um lado, adequadas a alcançar o objetivo de evitar a impunidade. Com efeito, como explica o Tribunal de Justiça, “tendo em conta o adágio 'aut dedere, aut judicare’ (extraditar ou julgar), a não extradição dos nacionais seja geralmente compensada pela possibilidade de o Estado-Membro requerido proceder criminalmente contra os seus próprios nacionais por infrações graves cometidas fora do seu território". O mesmo já não sucede, contudo, em relação aos não nacionais: o Estado-Membro requerido é, em regra, incompetente para julgar infrações "quando nem o autor nem a vítima da suposta infração têm a nacionalidade desse Estado-Membro"32. Foi neste contexto que, nas suas Conclusões, Yves Bot não considerou as situações dos nacionais de um certo Estado-Membro e dos cidadãos da União não nacionais desse mesmo Estado-Membro comparáveis ${ }^{33}$ : para o caso concreto, a situação de cada uma destas duas categorias de cidadãos da União só seria comparável se ambas pudessem ser julgadas na Letónia por infrações cometidas num Estado terceiro - o que não era o caso. Com efeito, a Letónia só podia proceder criminalmente contra nacionais letões, não contra nacionais estónios ou de outros Estados-Membros. Assim, o risco de impunidade da pessoa abrangida por um pedido de extradição subsiste "se o Estado-Membro requerido não previu no seu direito interno uma competência jurisdicional que lhe permita julgar um nacional de outro Estado-Membro suspeito de ter cometido uma infração no território de um Estado terceiro" ${ }^{34}$.

ter relativamente aos seus cidadãos e a desconfiança dos Estados relativamente aos sistemas judiciários estrangeiros.

${ }^{31}$ Cfr. acórdão Petrubbin..., cons. 35-37.

${ }^{32}$ Cfr. acórdão Petrubbin..., cons. 39-40.

${ }^{33}$ Cfr. Conclusões Petrubhin..., cons. 57-70.

${ }^{34}$ Conclusões Petrubhin..., cons. 64. 
A questão estava em saber, por outro lado, se não existia, em alternativa à extradição, uma medida menos atentatória do exercício do direito à livre circulação e residência associado ao estatuto de cidadão da União e que permitisse alcançar com a mesma eficácia o objetivo de evitar o risco de impunidade ${ }^{35}$. Foi neste contexto que o Tribunal de Justiça chamou à colação a Decisão-Quadro 2002/ 584 relativa ao mandado de detenção europeu ${ }^{36}$. Aqui, o Tribunal de Justiça procurou, por via de um mecanismo de cooperação e de assistência mútua existente em matéria penal no quadro do direito da União, conciliar a necessidade de preservar os cidadãos da União de medidas suscetíveis de os privar do direito de livre circulação e de residência associado ao seu estatuto de cidadão da União e de salvaguardar o objetivo de lutar contra a impunidade em caso de infrações penais ${ }^{37}$. Assim, num caso em que um Estado terceiro dirija a um Estado-Membro um pedido de extradição de um cidadão da União da nacionalidade de outro Estado-Membro, sem que exista acordo de extradição entre a União e o Estado terceiro em causa, a solução passa por "privilegiar a troca de informações com o Estado-Membro da nacionalidade do interessado, a fim de dar às autoridades desse Estado-Membro, desde que sejam competentes, ao abrigo do respetivo direito nacional, para proceder criminalmente contra essa pessoa por atos praticados fora do território nacional, a oportunidade de emitir um mandado de detenção europeu para fins de procedimento penal', pois o Estado-Membro da nacionalidade do presumível autor da infração pode, ao abrigo do art. 1. ${ }^{\circ}$, n. ${ }^{\text {os }} 1$ e 2, da Decisão-Quadro 2002/584, emitir um mandado de detenção europeu para a entrega dessa pessoa para fins de procedimento penal ${ }^{38}$.

Por outras palavras, estando em causa a extradição de cidadãos da União, o adágio aut dedere aut judicare ("extraditar ou julgar") é substituído pelo adágio próprio ao modelo jurídico da integração europeia que é o da cooperação leal - a cooperação leal entre os Estados-Membros envolvidos, aquele de acolhimento a quem foi

\footnotetext{
${ }^{35}$ Cfr. acórdão Petrubhin..., cons. 41.

${ }^{36}$ Decisão-Quadro 2002/584/JAI do Conselho, de 13 de junho de 2002, relativa ao mandado de detenção europeu e aos processos de entrega entre os Estados-Membros (JO 2002, L 190, p. 1), conforme alterada pela Decisão-Quadro 2009/299/JAI do Conselho, de 26 de fevereiro de 2009 (JO 2009, L 81, p. 24).

${ }^{37}$ Cfr. acórdão Petrubbin..., cons. 43 e 47.

${ }^{38}$ Acórdão Petrubhin..., cons. 48.
} 
dirigido o pedido de extradição e aquele da nacionalidade a quem deve ser dada a oportunidade de emitir um mandado de detenção europeu - tendente à proteção de um cidadão da União. Para o caso concreto, o Tribunal de Justiça aqui incita o Estado-Membro da nacionalidade de Aleksei Petruhhin, a Estónia (desde que seja competente, à luz do seu direito interno, para proceder criminalmente contra ele por atos praticados fora do seu território), a emitir um mandado de detenção europeu a fim de este ser executado pelas autoridades competentes do Estado-Membro no qual se encontra detido, a Letónia. Refere o Tribunal de Justiça que "[ao] cooperar desse modo com o Estado-Membro da nacionalidade do interessado e ao dar prioridade a esse eventual mandado de detenção sobre o pedido de extradição, o Estado-Membro de acolhimento atua de forma menos atentatória do exerć́cio do direito à livre circulação, evitando simultaneamente, na medida do possivel, o risco de a infração objeto do procedimento penal ficar impune." 39

A resposta do Tribunal de Justiça é, ainda assim, em geral e em concreto, condicionada: o Estado-Membro da nacionalidade do cidadão da União, in casu a Estónia, deve ser competente, à luz do seu direito interno, para proceder criminalmente contra ele por atos praticados fora do seu território para, assim, emitir um mandado de detenção europeu que obrigue o Estado-Membro de acolhimento, a Letónia. $\mathrm{Na}$ hipótese (ainda assim remota) de esta condição não se verificar, a resposta dada pelo Tribunal de Justiça à última questão prejudicial assume especial relevância. Aqui, o órgão jurisdicional de reenvio pretendia saber se, caso o Estado-Membro requerido pretenda extraditar um nacional de outro Estado-Membro a pedido de um Estado terceiro, ainda assim, deve zelar pela observância das garantias previstas no art. 19. ${ }^{\circ}$ CDFUE. A resposta positiva do Tribunal de Justiça não surpreende: uma vez que a situação em causa está abrangida pelo âmbito de aplicação do direito da União na aceção do art. 51. ${ }^{\circ}$, n. $^{\circ} 1, \mathrm{CDFUE}^{40}$, a proteção concedida pelo art. 19. ${ }^{\circ}$

\footnotetext{
${ }^{39}$ Acórdão Petrubbin..., cons. 49.

${ }^{40}$ Sobre a jurisprudência inaugurada no acórdão TJUE de 26 de fevereiro de 2013, Fransson, Processo C-617/10, EU:C:2013:105, cons. 17-23 e 29, a propósito desta disposição, cfr., entre outros, Angela Ward, “Article 51", e Koen Lenaerts e José Antonio Gutiérrez-Fons, "The Place of the Charter in the EU Constitutional Edifice", in The EU Charter of Fundamental Rights. A Commentary, ed. Steve Peers et al. (Oxford: Hart Publishing, 2014), 1413-1454 e 1566-1568, respetivamente; Daniel Sarmiento, “Who's afraid of the Charter? The Court of Justice, national courts and the new framework of fundamental rights protection in
} 
CDFUE é aplicável ${ }^{41}$. De resto, o Tribunal de Justiça confirma a sua jurisprudência anterior $^{42}$ no sentido de que a apreciação de uma eventual violação desta disposição deve ser feita em concreto e não bastar-se com a mera constatação de que o Estado (terceiro) requerente é parte na $\mathrm{CEDH}$, por exemplo: na medida em que a autoridade competente do Estado-Membro requerido disponha de elementos objetivos, fiáveis, precisos e devidamente atualizados, como decisões judiciais internacionais, ou decisões, relatórios ou outros documentos elaborados por órgãos do Conselho da Europa ou pertencentes ao sistema das Nações Unidas, que comprovem um risco real de trato desumano ou degradante das pessoas no Estado terceiro requerente, deve apreciar a existência desse risco no momento de decidir sobre a extradição de uma pessoa para esse Estado e, sendo o caso, obstar à extradição ${ }^{43}$.

O resultado é, assim, duplamente positivo: não sendo a cidadania da União suficiente para obstaculizar a extradição em virtude do direito interno do EstadoMembro da nacionalidade não alargar a competência penal a atos praticados pelos seus nacionais fora do seu território, a proteção concedida ao abrigo do art. 19. CDFUE será ainda assim operante. Da mesma forma que em Rottmann em relação à apatridia, em Petrubhin a diferenciação de tratamento entre nacionais e não nacionais em relação à extradição subsiste; mas, e também à semelhança do que sucedeu no caso Rotmann em relação à proteção contra a apatridia, também em Petrubhin a proteção contra a extradição é reforçada por via da cidadania da União e da proteção dos direitos fundamentais na ordem jurídica da União.

É preciso ter em conta que a perceção de fronteiras tem consequências, tem significado, em relação ao sentimento de pertença a determinada comunidade. O

\footnotetext{
Europe", Common Market Law Review, 50 (2013): 1267-1304; e, entre nós, Alessandra Silveira, "Cidadania Europeia e Direitos Fundamentais", in Direito da União Europeia - Elementos de Direito e Políticas da União, coord. Alessandra Silveira, Mariana Canotilho e Pedro Madeira Froufe (Coimbra: Almedina, 2016), 51-67.

${ }^{41}$ Cfr. acórdão Petrubbin..., cons. 52-54.

${ }^{42}$ Em relação ao art. $4 .{ }^{\circ} \mathrm{CDFUE}$ (proibição da tortura e dos tratos ou penas desumanos ou degradantes), cfr. acórdão Aranyosi, de 5 de abril de 2016, Processos C-404/15 e C-659/15 PPU, EU:C:2016:198, cons. 77-104.

${ }^{43}$ Cfr. acórdão Petrubbin..., cons. 55-60; no mesmo sentido, cfr. Conclusões Petrubbin, cit., cons. 71-83.
} 
significado das fronteiras territoriais entre os Estados-Membros tem-se tornado cada vez mais fluído, menos estanque, em razão do processo de integração ${ }^{44}$ - este é o resultado de um processo de integração desde a origem carreado por liberdades de circulação entre Estados-Membros. Mas se o processo de integração tem fragmentado o significado das fronteiras intraeuropeias, pois assenta na ausência de fronteiras internas ${ }^{45}$, tem contribuído para a emergência de uma fronteira extraeuropeia por todos partilhada. Nesse sentido, o acórdão Petrubbin é apenas um exemplo de uma jurisprudência que tem vindo a valorizar o território da União considerado no seu todo para a proteção dos cidadãos da União contra medidas nacionais que tenham por efeito o seu afastamento desse território ${ }^{46}$. A cidadania da União tem, nessa medida, a virtualidade de proporcionar novas soluções à questão da pertença à comunidade política europeia em emergência com o intuito de forjar uma identidade política europeia - mas também não reclama como condição imprescindível para a sua subsistência/sobrevivência a construção de um sentimento de identidade análogo àquele que o património jurídico edificado pelo Estado-Nação habituou.

\section{Considerações conclusivas}

A identidade, percecionada enquanto realidade dinâmica, está em constante transformação. A questão da identidade reconduz-se à questão "quem sou eu?". A identidade política, contudo, não se resume apenas à questão de saber "quem sou?", mas também integra a de saber "de onde sou?" - de onde venho, para onde vou, onde está o porto seguro que me dá guarida, proteção?

\footnotetext{
${ }^{44}$ Por referência a Francisco Lucas Pires, Introdução ao Direito Constitucional Europeu..., 8, que, a propósito da crise do Estado na era da pós-modernidade, refere que "o território se tornou menos estanque, a população menos exclusiva, a soberania menos indivisivel.".

${ }^{45} \mathrm{Cfr}$. art. 3..$^{\circ}$, n. ${ }^{\circ}$ 2, TUE e art. $26^{\circ}$, n. $^{\circ}$ 2, TFUE, respeitantes ao espaço de liberdade, segurança e justiça e ao mercado interno, respetivamente.

${ }^{46}$ Cfr. Acórdão TJUE de 8 de março de 2011, Zambrano, Processo C-34/09, EU:C:2011:124; acórdão TJUE de 13 de setembro de 2016, Rendón Marín, Processo C-165/14, EU:C:2016:675; e acórdão TJUE de 13 de setembro de 2016, CS, Processo C-304/14, EU:C:2016:674.
} 
O propósito da cidadania da União enquanto elemento identitário da União é fomentar uma resposta a esta questão que comporte, não só, mas também a própria União. Na pequena amostragem de jurisprudência de que demos aqui conta - e outros exemplos seriam de considerar -, a solução dada a problemas concretos de cidadãos da União decorre do seu estatuto de cidadão da União, ou seja, de membro da comunidade política europeia ("civis europens sum" ${ }^{47}$ ), e da operatividade do princípio da cooperação leal nas relações entre EstadosMembros - e isto, em alternativa à proibição de restrições/entraves à liberdade de circulação. Nesta jurisprudência, a atenção parece (começar a) centrar-se nos cidadãos da União enquanto membros da comunidade política da União e nos direitos que decorrem desse estatuto, e não enquanto nacionais dos EstadosMembros que circulam e/ou residem em Estados-Membros distintos do da nacionalidade. O sentido da cidadania da União que começa então a despontar, a dar pequenos mas visíveis passos na jurisprudência do Tribunal de Justiça, não é apenas o de promover a liberdade de circulação dos cidadãos da União no território dos distintos Estados-Membros e a integração do cidadão dinâmico à comunidade política do Estado-Membro de acolhimento - nessa medida, a cidadania da União participa e reforça do discurso de promoção da mobilidade inerente às liberdades de circulação já próprio ao modelo de integração por via do mercado; é também o de promover a integração numa comunidade política europeia em emergência, fomentando, num caminho que se faz caminhando em conjunto, um sentimento de pertença e de identidade no seio dessa comunidade - e isto faz-se, ou deve fazer-se, independentemente de o cidadão da União circular ou não.

E, por fim, repare-se que em nenhum dos dois acórdãos a solução dada pelo Tribunal de Justiça assentou numa lógica top-down de domesticação do nível estadual de decisão e de atuação ao direito da União enquanto direito produzido a nível supranacional. Imperou, sim, a lógica da produção de capacidades/legitimidades

\footnotetext{
${ }^{47}$ Conclusões Konstantinidis, Francis Jacobs, 9 de dezembro de 1992, Processo C-168/91, EU:C:1992:504, cons. 46.
} 
de decisão e de atuação fundadas no entrelaçamento das várias ordens jurídicas mobilizáveis e que integram o todo sistémico própria à metódica da internormatividade do modelo jurídico da integração. 



\title{
Os programas de transferência de renda e a erradicação do trabalho infantil no Brasil
}

\author{
Suzéte da Silva Reis*
}

RESUMO: Com o presente trabalho pretende-se verificar se e em que medida os programas de transferência de renda contribuem para a erradicação do trabalho infantil. Sabe-se que esta violação aos direitos humanos e fundamentais de crianças e adolescentes tem consequências graves e irreparáveis. A adoção dos programas de transferência de renda apresenta-se como uma alternativa importante, na medida em que as famílias, para receberem os valores, precisam cumprir com determinadas condicionantes, dentre elas, retirar as crianças da situação de trabalho. Para realização da presente pesquisa, o método empregado foi o dedutivo e a técnica de pesquisa empregada foi a bibliográfica.

PALAV RAS-CHAVE: direitos fundamentais - trabalho infantil-transferência de renda.

ABSTR ACT: This paper seeks to verify if and to what extent income transfer programs contribute to the eradication of child labor. It is known that this violation of the buman and fundamental rights of children and adolescents has serious and irreparable consequences. The adoption of income transfer programs is an important alternative, since families need to comply with certain conditions, such as removing children from the work situation. For the accomplishment of the present research, the method used was the deductive one and the research technique used was the bibliographical one.

KEYWORDS: fundamental rights - child labour - income redistribution.

\footnotetext{
* Professora do Programa de Pós-Graduação em Direito da Universidade de Santa Cruz do Sul UNISC.
} 


\section{Introdução}

A efetivação dos direitos fundamentais de crianças e adolescentes ganhou ênfase com a consagração da proteção integral pela Constituição Federal brasileira de 1988. Desde então, inúmeras ações foram desenvolvidas no sentido de garantir a observância dos preceitos constitucionais e infraconstitucionais. Dentre tantos temas, o trabalho infantil tem pautado a agenda brasileira, pois representa uma violação não apenas aos direitos fundamentais, mas também aos direitos humanos de crianças e de adolescentes. Quando inseridos antes da idade mínima no mercado de trabalho, os prejuízos são imensos, tanto nos aspectos físicos quanto psicológicos. O trabalho infantil compromete a saúde e a vivência da infância e, em decorrência, a efetivação dos demais direitos fundamentais. Além disso, a vida profissional futura também é comprometida, na medida em que a inserção precoce no mercado de trabalho implica na inserção precária quando na vida adulta.

Nas últimas duas décadas, as ações de combate e erradicação do trabalho infantil foram intensificadas e apresentaram resultados importantes. Contudo, o trabalho infantil persiste. Entre 2001 e 2013, a redução de crianças e adolescentes em situação de trabalho infantil atingiu 58,1\%, enquanto a média mundial, no mesmo período, foi de 36\%. O percentual é resultado da adoção de políticas integradas de combate à pobreza, destacando-se, dentre elas, os programas de transferência de renda. No entanto, apesar da redução alcançar um patamar considerável na última década, em 2014 se constatou um crescimento de 9,3\% no número de crianças e adolescentes em situação de trabalho no Brasil.

Tal fato causa preocupação e sinaliza a necessidade de investigar e fortalecer as estratégias de combate ao trabalho infantil. Em momentos de crises econômicas, os mais vulneráveis são também os mais atingidos. Nesse contexto, crianças e adolescentes acabam sendo inseridos precocemente no mercado de trabalho para auxiliar e complementar a renda familiar, precarizando ainda mais a sua condição, pois quanto mais cedo ocorre o ingresso no mercado de trabalho, menores serão as chances de inserção qualificada no futuro, perpetuando o ciclo intergeracional de pobreza. 


\section{A necessidade de erradicação do trabalho infantil}

A Constituição Federal de 1988 e o Estatuto da Criança e do Adolescente de 1990 inauguraram uma nova fase para o Direito da Criança e do Adolescente com a consagração da teoria da proteção integral, tornando-se o referencial para a construção de uma base teórica acerca dos direitos fundamentais da população infanto-juvenil. Estes instrumentos estabelecem prioridade absoluta no atendimento de crianças e adolescentes, bem como preveem a criação de sistema de garantias que visa assegurar a proteção dos direitos fundamentais da população infanto-juvenil. Em consonância com essas normativas, inúmeros avanços podem ser observados nas últimas três décadas, nas mais diversas áreas.

Entretanto, algumas violações de direitos ainda persistem e o trabalho infantil representa uma delas. A legislação brasileira veda o trabalho antes dos dezesseis anos de idade, salvo na condição de aprendiz, a partir dos quatorze anos. A vedação encontra-se prevista no art. $7^{\circ}$, inciso XXXIII da Constituição Federal de 1988. Além da previsão constitucional, outras normativas infraconstitucionais asseguram a proteção de crianças e adolescentes contra a exploração do trabalho infantil.

De acordo com o Instituto Brasileiro de Geografia e Estatística (IBGE) ${ }^{1}$ em 2013, havia 325 mil pessoas com idade entre 5 e 13 anos trabalhado em atividades agrícolas e 181 mil em atividades não agrícolas. Em 2014, o número passou para 344 mil em atividades agrícolas e 210 mil em atividades não agrícolas. Dessas, 484 mil tinham idade entre 10 e 13 anos. As demais, 70 mil, tinham idade entre 5 e 13 nos. $\mathrm{O}$ aumento do número de crianças e de adolescentes em situação de trabalho causa preocupação, tendo em vista que o Brasil havia alcançado a marca de 58,1\% de redução do trabalho infantil no período compreendido entre 2001 e 2013.

Dentre as causas que levam ao trabalho infantil, as condições econômicas, em especial a pobreza, são relevantes: "bá um forte argumento, tanto teórico como empirico, de que a vulnerabilidade econômica associada à pobrez̧, riscos e choques desempenha um papel essencial em

\footnotetext{
1 "Página Inicial", Instituto Brasileiro de Geografia e Estatística, acesso em Setembro 13, 2016, http:// www.ibge.gov.br.
} 
impelir as crianças para o trabalho"2. As famílias pobres, que possuem mais dificuldade de acesso ao crédito, têm menor probabilidade de conseguirem adiar o envolvimento das crianças no trabalho e de investir na sua educação e maior probabilidade de se verem forçadas a recorrer ao trabalho infantil para suprir necessidades básicas e enfrentar a insegurança ${ }^{3}$.

As condições de pobreza enfrentadas pelas famílias são, portanto, fatores que contribuem para a perpetuação do trabalho infantil. O enfrentamento e as ações contínuas contra o trabalho infantil requerem políticas nacionais que auxiliem as famílias a saírem da condição de vulnerabilidade em que se encontram.

A partir dessa perspetiva, os países que ainda não alcançaram patamares de estabilidade econômica são aqueles nos quais o trabalho infantil persiste de forma mais aguda. Os países em desenvolvimento perderam autonomia, ficando mais dependentes do capital internacional e, em consequência, ficando mais vulneráveis às flutuações dos mercados globais, dos colapsos financeiros e dos encargos das dívidas. Para o autor, quanto "mais pobre um país, mais limitados são os seus recursos para enfrentar os efeitos nefastos da exposição ao mercado mundial'4.

Associado ao fator econômico e vulnerabilidades econômicas e sociais, uma série de contingências relacionadas a isso impulsionam o trabalho infantil. Dentre elas está o desemprego, as doenças, a deficiência ou a idade avançada que surgem ao longo da vida e que geram instabilidades nas famílias e, ao final, contribuem para a exploração do trabalho infantil. Em razão disso, o trabalho infantil tem que ser enfrentado a partir de uma "combinação de instrumentos no âmbito de uma abordagem de sistemas integrados" 5 .

Além dos prejuízos educacionais, sociais e econômicos decorrentes do trabalho infantil, é preciso considerar os riscos à integridade física e a saúde daqueles que

\footnotetext{
${ }^{2}$ Cfr. Organização Internacional do Trabalho, Relatório mundial sobre trabalho infantil: Vulnerabilidade econômica, proteção social e luta contra o trabalho infantil (1. ${ }^{a}$ ed., Genebra: Secretariado Internacional do Trabalho, 2013), 17.

${ }^{3}$ Cfr. Organização Internacional do Trabalho, Relatório Mundial.

${ }^{4}$ Cfr. Kristoffel Lieten, "Globalização e trabalho infantile", O problema do trabalho infantil-temas e soluções, org. G. K. Lieten (Trad. Danielle Annoni, Curitiba: Multideia, 2007), 29.

${ }^{5}$ Cfr. Organização Internacional do Trabalho, Relatório Mundial, 24.
} 
são expostos precocemente ao trabalho. A desconstrução de um dos mitos sobre o trabalho infantil, segundo o qual a criança deve aprender a trabalhar desde cedo, é crucial para o enfrentamento do trabalho infantil.

A legislação brasileira permite o trabalho a partir dos dezesseis anos e, excecionalmente, a partir dos quatorze anos de idade, na condição de aprendiz. Assim, a interpretação desse preceito constitucional leva "ao entendimento de que a proibição a qualquer trabalho a menores de dezesseis anos, de acordo com a própria expressão gramatical, estende-se a todo o tipo de atividade laboral, como medida protetiva da integridade física, psíquica e social da criança e do adolescente" ${ }^{\text {". }}$.

A vedação ao trabalho em condições insalubres ou perigosas, visa assegurar a proteção da criança e do adolescente que, expostos precocemente ao trabalho, ficam expostos a riscos que comprometem a sua integridade física. Os trabalhadores têm assegurada a proteção quanto à sua integridade física e as condições de trabalho que lhe garantam a proteção a sua saúde. Contudo, constantemente crianças e adolescentes são expostos as mais degradantes e perigosas formas de trabalho. Nesse sentido, é "necessário deslocar a discussão da relação do trabalho com o desenvolvimento do homem. Não se trata de uma mera adaptacão das características e condiçoes de trabalho às características das crianças e adolescentes, mas de como trabalhar pode afetar a construção de um indivíduo que se quer saudável e produtivo"’ . Os prejuízos decorrentes da exposição precoce ao trabalho afetam sobremaneira a saúde das crianças e adolescentes.

O trabalho infantil traz prejuízos imensuráveis e irreversíveis, pois representa uma grave violação aos direitos humanos, na medida em que "nega o direito fundamental à infância, em afronta ao direito da criança e a ser criança, na qualidade de sujeito de direito em peculiar condição de desenvolvimento, a merecer absoluta prioridade e primazia"s.

A negação da infância e a naturalização do trabalho infantil representam uma

\footnotetext{
${ }^{6}$ Cfr. Organização Internacional do Trabalho, Relatório Mundial, 20-21.

${ }^{7}$ Cfr. Miguel M. Alves Lima, "O Direito da criança e do adolescente: fundamentos para uma abordagem principiológica” (PhD diss., Universidade Federal de Santa Catarina, 2001), 07.

${ }^{8}$ Cfr. Flavia Piovesan e Gabriela de Luca, "Gênese e atualidade da proteção do trabalho infantil nas normas internacionais", in Criança, Adolescente, Trabalho, coord. Andrea Saint Pastous Nocchi et al. (São Paulo: Ltr, 2010), 362.
} 
violação aos direitos humanos de crianças e de adolescentes. Os prejuízos decorrentes da exploração do trabalho infantil, em qualquer uma das suas formas, são irreparáveis.

A proteção dos direitos humanos e fundamentais exige a adoção de critérios hermenêuticos que priorizem a proteção integral. Assim, a "urgência da situação exige ação consciente e determinada por parte dos gestores públicos, mas também da parte dos agentes responsáveis pela implementação da lei e afirmação dos direitos humanos". Portanto, Estado e sociedade devem assumir a responsabilidade pela observância dos direitos fundamentais de crianças e adolescentes e, em consequência, promover a erradicação do trabalho infantil.

Diante das consequências gravíssimas decorrentes do trabalho infantil, foram adotadas estratégias para promover a sua erradicação. Dentre elas, destacam-se a atuação do Fórum Nacional de Erradicação do Trabalho Infantil (FNPETI), da Comissão Nacional de Erradicação do Trabalho Infantil (CONAETI), da Comissão de Erradicação do Trabalho Infantil da Justiça do Trabalho, do Ministério Público do Trabalho, dos Juizados da Infância e Juventude. Entretanto, considerando-se que os fatores econômicos têm papel preponderante para o ingresso antes da idade mínima no mercado de trabalho, destaca-se a importância dos programas de transferência de renda instituídos pelo governo brasileiro e que contribuíram, sobremaneira, para a redução do trabalho infantil.

\section{Os impactos dos programas de transferência de renda e a erradicação do trabalho infantil no Brasil}

Uma das alternativas eficazes no combate ao trabalho infantil está na garantia de condições básicas, capazes de assegurar as condições mínimas às famílias, evitando assim que as crianças sejam enviadas para o trabalho.

A garantia de rendimentos mínimos, com a consequente segurança econômica, mesmo que em níveis mínimos, pode reduzir a vulnerabilidade social. Em geral, esses mecanismos estão associados a outros elementos que possibilitam às famílias

\footnotetext{
${ }^{9}$ Cfr. Flavia Piovesan e Gabriela de Luca, "Gênese e atualidade da protecção", 19.
} 
o atendimento nas áreas da saúde, educação, emprego e renda. A prevenção e o enfrentamento do trabalho infantil, portanto, perpassa a implementação de programas de proteção social.

No Brasil, a implementação de políticas públicas voltadas à erradicação do trabalho infantil data dos anos 1990, quando durante o governo Fernando Henrique Cardoso, foi lançado pelo Ministério da Educação um programa de garantia de renda mínima voltado aos municípios que possuíam, à época, receita tributária per capita inferior à média do seu estado. Em 11 de abril de 2001, foi aprovada a Lei n. ${ }^{\circ}$ 10.219, que criou o Programa Bolsa Escola, que posteriormente foi substituído pelo Programa Bolsa Família, destinado às famílias em estado de pobreza ou de extrema pobreza.

Antes disso, em 1996, teve início o Programa de Erradicação do Trabalho Infantil (PETI) que inicialmente era voltado ao combate ao trabalho de crianças em carvoarias na região de Três Lagoas, no Mato Grosso do Sul, e que, posteriormente, foi ampliado para todo o país de forma articulada com o Fórum Nacional de Prevenção e Erradicação do Trabalho Infantil (FNPETI). O objetivo do PETI era promover um conjunto de ações voltadas à retirada das crianças e dos adolescentes com menos de dezesseis anos do trabalho. Dentre suas ações, destacam-se a transferência direta de renda às famílias, a oferta de inclusão das crianças e dos adolescentes em situação de trabalho em programas de orientação e de acompanhamento e a exigência de frequência à escola. No ano de 2005, o PETI foi integrado com o Programa Bolsa Família, aprimorando a gestão da transferência de renda.

A principal alteração, porém, ocorreu em 2011, quando o PETI foi instituído pela Lei Orgânica de Assistência Social (LOAS) como "um programa de caráter intersetorial, integrante da Politica Nacional de Assistência Social, que compreende: transferências de renda; trabalho social com famílias e oferta de serviços socioeducativos para crianças e adolescentes que se encontram em situação de trabalho" ${ }^{\prime 10}$. Em 2013, ocorreu o reordenamento do PETI, objetivando acelerar as ações de prevenção e erradicação do trabalho infantil, a partir dos dados apresentados pelo Censo IBGE de 2010.

10 "Programa de Erradicação do Trabalho Infantil (PETI)", Ministério do Desenvolvimento Social, Acesso em setembro 16, 2016. 
O trabalho infantil é multifacetário e tem, dentre suas causas, outros fatores que contribuem para a sua continuidade além do fator econômico. A pobreza "é identificada como um fenômeno multidimensional, que necessita de um conjunto de programas microeconômicos integrados para a sua superação, além de contar com condições macroeconômicas favoráveis" $" 11$ e é, sem dúvida, um dos fatores preponderantes para que as famílias enviem os filhos para o trabalho.

Nesse sentido, o enfrentamento da pobreza é crucial. E, para tanto, se faz necessário enfrentar as suas causas, dentre elas a desigualdade na distribuição de renda e de riqueza socialmente produzida. As políticas de enfrentamento à pobreza, portanto, exigem uma articulação com a política econômica, a ampliação da inserção de jovens no sistema educacional, a ampliação das políticas públicas de geração de emprego e de redistribuição de renda ${ }^{12}$.

A pobreza é estigmatizada como uma situação humilhante que impõe silêncio e vergonha aqueles que nela se encontram. Portanto, ao dar voz aos que estão em situação de pobreza, abre-se a possibilidade de iniciar o resgate da sua autonomia. O recebimento de uma renda mensal também permite o desencadeamento de processos de autonomização individual em múltiplos níveis ${ }^{13}$.

No entanto, nem sempre a adoção de ações específicas é suficiente ou é compreendida como um mecanismo eficiente. Porém, essas ações são necessárias, particularmente para auxiliar na erradicação do trabalho infantil.

Nesse sentido, as políticas públicas são fundamentais, na medida em apontam para a resolução de um problema público reconhecido como tal na agenda governamental. Do mesmo modo, é correto dizer que as mesmas fazem referência as interações, alianças e conflitos entre os diferentes atores públicos, para-públicos e privados, para a resolução de um problema coletivo que requer uma ação concentrada ${ }^{14}$.

\footnotetext{
${ }^{11}$ Cfr. Maria Cristina Cacciamali; Fábio Yatei e Natália Ferreira Batista., "Impactos do programa bolsa família federal sobre o trabalho infantil e a frequência escolar", Revista de Economia Contemporânea 14, 2 (2010): 273. ${ }^{12}$ Cfr.M. O. da Silva.; M. C. Yazbec e G. di Giovani, A Política Social Brasileira no Século XXI: a prevalência dos programas de transferência de renda (São Paulo: Cortez, 2004).

${ }^{13}$ Cfr. Walquíria Leão Rego e Alessandro Pinzani, Vožes do Bolsa Família - autonomia, dinheiro e cidadania (São Paulo: Editota, 2013).

${ }^{14}$ Cfr. Joan Subirats et al., Análisis y gestión de políticas públicas (Barcelona: Planeta, 2012).
} 
Uma das políticas públicas de significativa importância foi a instituição dos programas de transferência de renda, que foi responsável pela retirada de inúmeras crianças e adolescentes do trabalho. Esses programas se "caracterizam por um conjunto de singularidades perante os programas tradicionais dos sistemas de seguridade social, mostrando-se adequados para fins de desenvolver programas de promoção bumana"15.

Ademais, as condicionalidades para a concessão do benefício Bolsa Família repercutem de modo mais amplo, alcançando a esfera educacional e de saúde. O programa se constitui em uma "política efetiva de combate à pobrez̧a, ao focar na população mais carente e apresentar condicionalidades que beneficiam a proteção e o acúmulo de capital bumano, por meio da obrigatoriedade de presença no sistema escolar e atendimento médico disponivel"16.

Contudo, impende referenciar que os programas de transferência de renda, por si só, não conseguem resolver o problema da pobreza no Brasil, pois como a pobreza é multifacetária, vários outros fatores precisam ser considerados.

Muito além da garantia de sobrevivência material das famílias mais pobres, ou em situação de pobreza extrema, o Programa Bolsa Família vai além: com os valores que são repassados mensalmente muitas beneficiárias saíram da invisibilidade, alcançaram certo grau de autonomia e independência que lhe possibilitou emanciparse. A exclusão econômica não tem repercussões apenas no aspecto material, porque abre espaço para a marginalização e a exclusão social, impedindo que muitas famílias tenham acesso aos serviços básicos como saúde e educação. Destituídas das garantias sociais básicas, o ciclo intergeracional de pobreza se reproduz ${ }^{17}$.

Especificamente em relação ao trabalho infantil, cumpre assinalar que, ainda que os programas de transferência de renda, como o Bolsa Família não exijam formalmente que a criança seja afastada do trabalho, a obrigatoriedade da frequência escolar reduz o tempo disponível para outras atividades. Desse modo, entende-se que a saída das crianças e adolescentes do mercado de trabalho seja um efeito colateral desses programas ${ }^{18}$.

\footnotetext{
${ }^{15}$ Cfr. Maria Cristina Cacciamali; Fábio Yatei e Natália Ferreira Batista, "Impactos do programa ", 272.

${ }^{16}$ Cfr. Maria Cristina Cacciamali; Fábio Yatei e Natália Ferreira Batista, "Impactos do programa ", 274.

${ }^{17}$ Cfr. Walquíria Leão Rego e Alessandro Pinzani, Vozes do Bolsa Família.

${ }^{18}$ Cfr. Ana Lúcia Kassouf e Andrea Rodrigues Ferro, “Avaliação do impacto dos programas bolsa-escola sobre o
} 
Isso porque o Programa Bolsa Família não é um programa de renda mínima universal e incondicional: condiciona o pagamento do valor da bolsa à frequência escolar e a vacinação das crianças, o que não representa um empecilho ao recebimento, na medida em que contribuem para o processo de formação de cidadãos e indivíduos responsáveis perante à comunidade política. O programa de transferência de renda condicionada, como é o caso do Bolsa Família, apresenta outras vantagens. Ao garantir as condições materiais mínimas, fornece a base da autonomia moral e ética. Incluindo o beneficiário no corpo dos cidadãos, promove um sentimento de identificação com a nação e de pertencimento. A exigência de que o beneficiário assuma responsabilidades perante a comunidade política e o Estado contribui para o aprendizado da cidadania, tanto na condição de sujeito de direitos, mas também de sujeito de deveres. Com a conformação que possui, o Programa Bolsa Família pode representar um instrumento de formação cívica ${ }^{19}$.

As condicionalidades necessárias para a manutenção do benefício, como a obrigatoriedade das famílias com crianças e adolescentes em idade escolar de zelarem pela frequência à escola, bem como manterem os cuidados básicos com saúde, como vacinação e acompanhamento nos postos de saúde ${ }^{20}$, mostram-se relevantes para a erradicação do trabalho infantil. Ao receberem o benefício, ainda que o valor não seja suficiente para retirar a família da condição de pobreza ou de pobreza extrema, os pais são motivados a retirar os filhos das situações de trabalho, enviando-os para a escola. Desse modo, a longo prazo, os benefícios serão ainda maiores.

Por outro lado, sabe-se que é necessário o controle, por parte dos gestores públicos, particularmente dos gestores municipais, acerca do atendimento das condicionalidades para manutenção do benefício. A partir desse controle, também é possível identificar as situações de trabalho infantil e estabelecer ou reforçar as estratégias para a sua erradicação.

\footnotetext{
trabalho infantil no Brasil', Pesquisa e Planejamento Econômico 35, 3 (dezembro 2005).

${ }^{19}$ Cfr. Walquíria Leão Rego e Alessandro Pinzani, Vozes do Bolsa Família.

${ }^{20}$ Cfr. Maurício Gregriani Testa; Paula Fronza e Maíra Petrini, "Análise da contribuição do Programa Bolsa Família para o enfrentamento da pobreza e a autonomia dos sujeitos beneficiários" Rev. Adm. Pública 47,6: (nov./dez. 2013): 1519-1541.
} 
Por fim, resta claro que os programas de transferência de renda não dão conta da erradicação do trabalho infantil, tampouco é suficiente para retirar as famílias beneficiárias da condição de pobreza. Todavia, os resultados não podem ser menosprezados, na medida em que, ao passar a receber o benefício, as famílias passaram a dar mais atenção à saúde e educação de seus filhos e, em consequência, retiraram as mesmas da situação de trabalho.

\section{Conclusão}

O sistema normativo-jurídico brasileiro assegura a proteção integral e o atendimento prioritário dos direitos fundamentais de crianças e adolescentes. A consagração da Teoria da Proteção Integral pelo texto constitucional e pelo Estatuto da Criança e do Adolescente demarca a rutura com as práticas menoristas até então predominantes, marcadas pela conceção de que as crianças pobres ou que viviam nas ruas deveriam ser o alvo das campanhas preventivas.

Nessa perspetiva, a prevenção e a erradicação do trabalho infantil devem ser os objetivos precípuos dos órgãos que compõem o sistema de garantia de direitos. Para tanto, a atuação do mesmo deve ser articulada com a sociedade civil, de forma a assegurar a observância dos direitos fundamentais da população infanto-juvenil e garantir que o trabalho infantil seja combatido em todas as suas formas.

O trabalho infantil é multifacetário e possui múltiplas causas. A conjunção dos fatores econômicos, associados às condições de pobreza extrema e a ineficiência das políticas públicas capazes de assegurar o atendimento integral dos direitos fundamentais de crianças e adolescentes é sobremaneira importante para análise da temática.

Por outro lado, a naturalização e a legitimação do trabalho infantil no imaginário social são também um fatores decisivos para a continuidade das práticas de exploração do trabalho de crianças e adolescentes. A naturalização do trabalho infantil contribui para que crianças se submetam a todas as formas de exploração do trabalho, que deve ser compreendido em sua aceção mais ampla, ou seja, deve ser compreendido 
com a realização de qualquer atividade econômica, não importando se existe ou não finalidade lucrativa. Diante disso, impõe-se a necessidade de implementação de ações voltadas à erradicação do trabalho infantil, em todas as suas formas.

Cumpre referir, nesse sentido, uma das políticas públicas implementadas pelo Estado brasileiro e que trouxe resultados importantes para a redução do trabalho infantil. Os programas de transferência de renda, em particular o Programa Bolsa Família, contribuiu para a saída de crianças e adolescentes do mercado de trabalho. As condicionalidades impostas para concessão do benefício, como a obrigatoriedade de frequência à escola, bem como o recebimento de uma renda mínima para assegurar, ainda que precariamente, as mínimas condições de sobrevivência, contribuíram para que as famílias retirassem seus filhos do trabalho.

Ainda que não sejam suficientes para promover a redução da pobreza e a erradicação do trabalho infantil, os programas de transferência de renda, como o Bolsa Família, têm apresentado importantes resultados. As famílias, especialmente as mais pobres, conseguem, com o valor do benefício, complementar a renda familiar e com isso, retirar os filhos do trabalho, enviando-os para a escola e assegurando-lhes um futuro mais digno.

Entretanto, como o trabalho infantil possui múltiplas causas, não é apenas a implementação dos programas de transferência de rendas que serão suficientes para erradicar o problema. Vários são os fatores que determinam a exploração do trabalho infantil e, por essa razão, as políticas públicas devem ser articuladas de forma a contemplar todos esses fatores. 



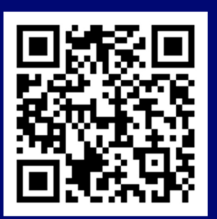

